UNIVERSIDADE DE SÃO PAULO

FACULDADE DE FILOSOFIA, LETRAS E CIÊNCIAS HUMANAS

DEPARTAMENTO DE HISTÓRIA

PROGRAMA DE PÓS-GRADUAÇÃO EM HISTÓRIA SOCIAL

MARIA SELMA DE MORAES ROCHA

UMA CONSTITUINTE SALGADA E MOLHADA: o direito à educação como questão nacional (1985-1988)

VERSÃO CORRIGIDA

São Paulo

2015 
MARIA SELMA DE MORAES ROCHA

UMA CONSTITUINTE SALGADA E MOLHADA: o direito à educação como questão nacional (1985-1988)

Tese apresentada ao Programa de Pós-Graduação em História Social do Departamento de História da Faculdade de Filosofia, Letras e Ciências Humanas da Universidade de São Paulo, para a obtenção do Título de Doutora em História.

De acordo, Jakinffenteptunandy Orientadora: Prof" "Dra. Leila Maria Gonçalves Leite Hernandez

VERSÃO CORRIGIDA

São Paulo

2015 
Rocha, Maria Selma de Moraes.

Uma Constituinte salgada e molhada: o direito à educação como questão nacional (1985-1988) / Maria Selma de Moraes Rocha. - São Paulo, 2015.

$309 \mathrm{f}$.

Tese de Doutorado (História) - Universidade de São Paulo, Faculdade de Filosofia, Letras e Ciências Humanas, Departamento de História, Programa de Pós-graduação, 2015.

Orientadora: Leila Maria Gonçalves Leite Hernandez

Título em inglês: A wet and salty constitution: the right to education as a national issue (1985-1988)

1. Assembleia Constituinte. 2. Constituição. 3. Educação. 4. Direitos. 5. Público e privado. I. Hernandez, Leila Maria Gonçalves Leite. II. Uma Constituinte salgada e molhada. 


\section{MARIA SELMA DE MORAES ROCHA}

\section{UMA CONSTITUINTE SALGADA E MOLHADA: o direito à educação como questão nacional (1985-1988)}

Tese apresentada ao Programa de Pós-Graduação em História Social do Departamento de História da

Faculdade de Filosofia, Letras e Ciências Humanas da Universidade de São Paulo, para a obtenção do Título de doutor em História.

Orientadora: Prof $\stackrel{a}{\text {. }}$. Dra. Leila Maria Gonçalves Leite Hernandez

Aprovada em: 16 de março de 2015

Prof $^{\text {a }}$. Dr ${ }^{\text {a }}$ Lisete Regina Gomes Arelaro

Prof. Dr. Wilson do Nascimento Barbosa

Prof ${ }^{\text {a }}$. Dr ${ }^{\text {a }}$ Carlota Boto

Prof. Dr. Mauricio Cardoso 
À memória de meu pai

Alceu Mendes Rocha

A Larissa, a Vitória e ao Bernardo

Com confiança

Com esperança 


\section{AGRADECIMENTOS}

Meus agradecimentos,

À professora Leila Leite Hernandez que orientou este trabalho com competente rigor, confiança, sensibilidade e interesse, dignificando com sua conduta a universidade pública, meu respeito e gratidão.

À Marta Lira Oliveira Veras e Thiago Almeida analistas legislativos técnicos em documentação e informação e Jéssica Fernandes de Oliveira do Centro de Documento da Câmara Federal que com presteza, paciência e gentileza forneceram todas as informações necessárias para o acesso as fontes documentais desta pesquisa.

Ao senhor João Alberto Oliveira Lima que nos enviou o trabalho de sua autoria no Senado Federal sobre a Constituinte de 88, indispensável a esta pesquisa.

Ao professor Dr. Elias Thomé Saliba cujas sugestões e contribuições na Banca de Qualificação contribuíram para a definição dos rumos deste trabalho.

À professora Carlota Boto pela leitura atenta, pelo incentivo carinhoso, pelas sugestões, contribuições e disponibilidade.

Às professoras Rosana Núbia e Natalina Ribeiro pela leitura crítica deste trabalho, pelas sugestões em relação à pesquisa documental e bibliográfica, pelas discussões construtivas, pelo apoio, carinho, solidariedade e bom humor, especialmente na fase final deste trabalho.

A Neide Gonçalves da Silva pelo apoio logístico.

Ao Laurindo dos Santos Junior e a Sonia Regina Beccheri pelo apoio permanente, incansável e carinhoso.

À Rosa Maria Tosta que me autorizou a sonhar.

À Jupira Cauhy pela solidariedade, empenho e apoio na preparação da qualificação.

Ao Rodrigo Cesar que, incansável e solidário, fez o competente e difícil trabalho de revisão técnica. 
À Lucia Escoteguy pelo trabalho de revisão.

Ao prof. Dr Zenir Campos Reis pela generosidade e pelo inestimável trabalho de revisão.

Ao Carlos Abicalil, que digna e esperançosamente tem dedicado o melhor de suas energias à construção de uma educação pública, democrática e de qualidade no Brasil por ter solidariamente me substituído para que este trabalho fosse concluído.

À Fatima Cleide, Maria Regina Queiroz Bachiega, Cristina Suster, Eduardo Massaaki Utima, Flávia de Angelis Santana, Raphael dos Santos Golin, Victor Pinto Amatucci da Escola Nacional de Formação da Fundação Perseu Abramo, por terem, muitas vezes e solidariamente, assumido, minhas tarefas para o desenvolvimento e conclusão desta pesquisa.

A todos com quem tenho compartilhado a experiência de construção de uma sociedade mais justa e solidária na qual o acesso às condições de produção da cultura seja um direito.

À minha mãe, meus irmãos, em particular ao meu irmão Hamilton Mendes Rocha pelo insubstituível apoio e incentivo.

À Thalita e demais familiares que me apoiaram e incentivaram.

Ao Julio meu filho, norte da esperança, pelo incentivo, pelo acolhimento, pelo carinho. 
A história nunca se fecha por si mesma e nunca se fecha para sempre. São os homens, em grupo confrontando-se como classes em conflito, que "fecham" ou "abrem" os circuitos da história. 


\section{RESUMO}

O objetivo do presente trabalho é compreender como a educação se tornou um direito no transcurso do processo da Constituinte, a partir da participação, da mobilização e da ação de um conjunto de sujeitos representantes da sociedade civil, além dos parlamentares eleitos por suas respectivas agremiações partidárias. Procurei identificar a configuração desse direito no processo de sua construção, isto é, quando as pluralidades heterogêneas dos discursos dos sujeitos manifestaram seu caráter dinâmico coincidindo, se chocando ou se tornando convergentes. Nesta perspectiva ganharam realce os silêncios que conferiram opacidade à memória, o registro e os projetos políticos com propostas contrastantes, e ambivalências, dissensos, consensos, pactos e rupturas se estabeleceram em circunstancias históricas específicas. Neste contexto o direito à educação se definiu no âmbito do conflito entre o público e o privado entre os anos de 1985 a 1988.

Palavras-Chave: Constituinte, Constituição, Educação, Direito, Público e Privado. 


\begin{abstract}
The aim of this research is to understand how education has been historically established as a right during the constitutional process, based on the analysis of participation, mobilization and action of a representative group from civil society, and parliamentarians elected by their party associations. I sought to identify the process of construction of that right focusing on the heterogeneous plurality of its actors' discourses, which expressed their dynamic character coinciding, crashing or being convergent. Some aspects were highlighted, such as the silence which gave opacity to memory, the political records and projects with contrasting proposals and the ambivalences, dissents, consensus, pacts and ruptures that were settled. In this context, the right to education was erected within the conflict between the public and private between the years 1985-1988.
\end{abstract}

Keywords: Constituent Assembly, Constitution, Education, Rights, Public and Private 


\section{SUMÁRIO}

Introdução 12

1 - As aventuras e as desventuras do processo de transição no Brasil ....................30

1.1 - O processo de desmilitarização, o jogo das tensões sociais e a Constituinte........ 30

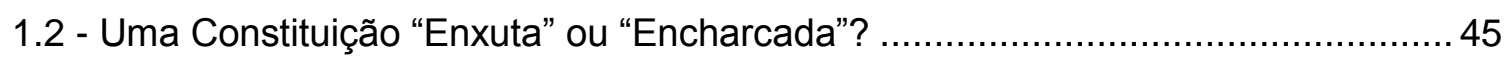

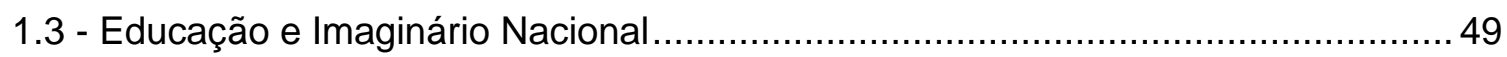

1.4 - Uma Constituição analítica: como o homem constrói o homem …………….........55

1.5 - O Estado entre o público e o privado e as representações da Nação .................... 69

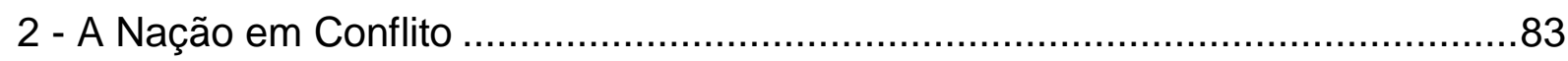

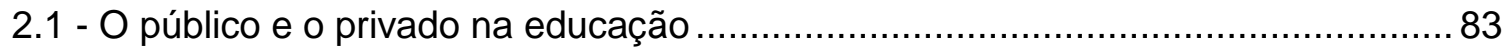

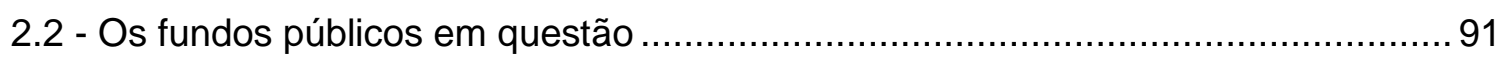

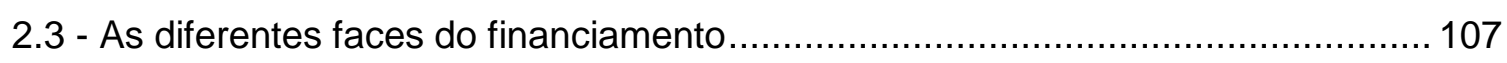

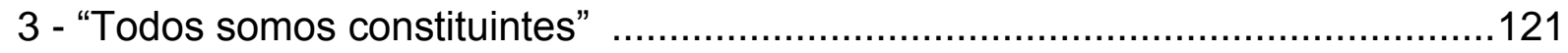

3.1 - A educação como questão nacional e democrática............................................. 121

3.2 - A educação e a cultura como centro da questão nacional democrática .............. 134

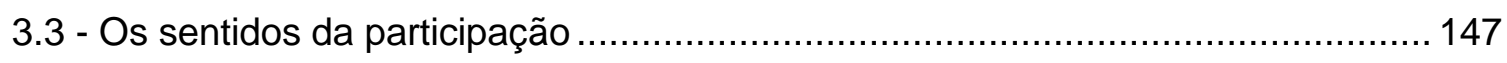

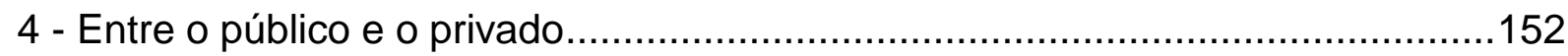

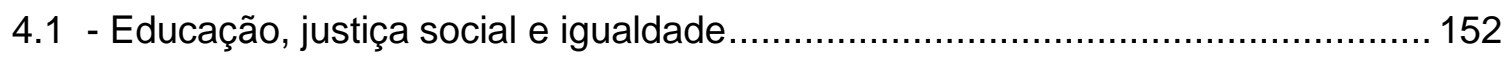

4.2 - A questão do financiamento: critérios e interesses das instituições .................... 163

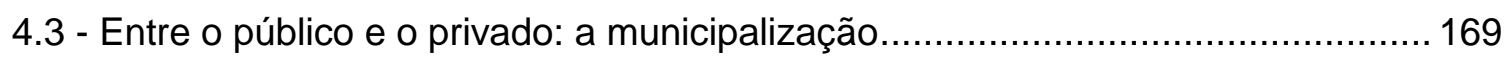

4.4 - Educação: dever do Estado ou direito da família? ............................................ 174

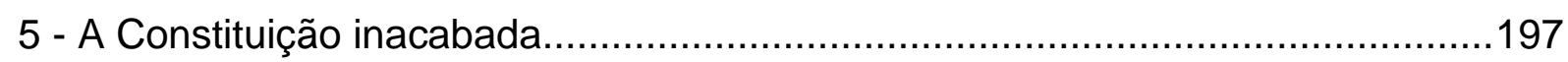

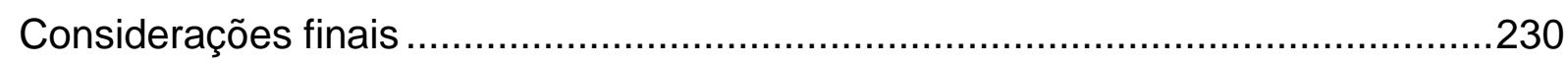

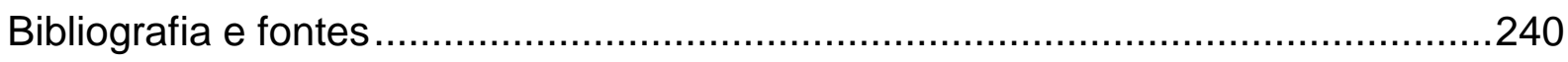

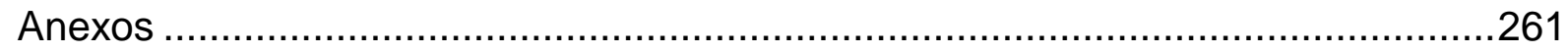




\section{INTRODUÇÃO}

Em 1987 foi instalada a Assembleia Nacional Constituinte no Brasil, que pretendia restabelecer a ordem democrática a partir de um processo tutelado pelas Forças Armadas em meio a uma profunda crise do Estado, depois de vinte e um anos de governos militares.

A crise iniciada a partir de 1974 colocava em questão o aparato legal e institucional voltado à promoção da violência por meio da repressão, tortura e eliminação física de muitos de seus opositores. A supressão das liberdades democráticas e do Estado de direito se constituíram em condições para o exercício ilimitado do monopólio da força e da coação física pelo Estado, seu instrumento específico, como diria Weber (Weber, 2012, p. 525).

O processo de distensão, que teve início no final de 1973, não pretendia pôr fim, abruptamente, ao Estado bonapartista ${ }^{1}$ voltado a fazer prosperar os interesses históricos do capitalismo sem a expressão direta da burguesia em sua condução. A

\footnotetext{
${ }^{1}$ Bonapartismo, uma expressão que se construiu historicamente a partir da memorável obra de Marx, O 18 Brumário de Luis Bonaparte, passou a designar uma forma específica de Estado, que se autonomiza frente a sociedade em razão de uma crise de hegemonia. $O$ paradigma bonapartista supõe uma crise caracterizada pelo confronto entre as classes sociais sem que nenhuma delas tenha força social suficiente para conquistar o poder político e dirigir toda a sociedade. Mas o conteúdo das políticas por ele levadas a efeito, sem o controle do parlamento, estão em sintonia com os interesses históricos da burguesia e com a ordem social por ela defendida. Dentre os pensadores e militantes de tradição marxista Leon Trotsky esteve entre os que tomou o paradigma bonapartista como referência para a compreensão do fascismo entendendo-o como uma forma particular da dominação burguesa. Trotsky, em seu último texto, reconhecia que a elevação do poder do Estado acima da sociedade, como circunstância resultante da agudização da luta de classes, foi uma das condições do fascismo. Todavia apontava que tal condição do Estado diferenciava-se pela circunstância histórica na qual o bonapartismo se estabelecia. O processo de autonomização do Estado, em oposição a democracia parlamentar, não mais correspondia a um impulso que fizesse prosperar a burguesia e o capitalismo. Em vez disso, o Estado autônomo, sustentado pela burocracia, a polícia e o aparelho militar resultava e favorecia a concentração dos meios de produção e do capital, não mais regulável pelo mercado. (Trotsky, 2014)

Outro pensador e militante de tradição marxista que teve importância para a análise do Estado bonapartista foi Antonio Gramsci. Seu pensamento distinguiu direções distintas para a crise de hegemonia em situações de autonomização do Estado. Considerando o bonapartismo como uma manifestação burguesa do cesarismo o autor identifica que Cesar, Napoleão I, Napoleão III, Cromwell, entre outros, tornaram-se personalidades "heroicas" como resultado da solução arbitral que representaram para situações históricas nas quais da luta sem sucesso pelo poder político resultou no equilíbrio de forças antagônicas na sociedade. A solução arbitral responde à circunstância de que a continuidade do confronta poderia significar a destruição recíproca. Gramsci considerou que o cesarismo poderia ser progressista quando sua ação ajudasse as forças progressistas na sociedade a triunfar, inversamente, seria reacionário quando levasse ao triunfo as forças reacionárias. Para Gramsci, nesse caso, tratou-se de distinguir o elemento prevalente na dialética restauraçãorevolução mesmo nas experiências históricas em que o processo de autonomização do Estado em relação à sociedade não se ampara em uma personalidade, mas em uma instituição.(Gramsci, 1989)
} 
liberalização que se anunciava, em meio à violenta repressão no País realizada pelos diferentes órgãos do aparelho de segurança, abrigava as crescentes contradições da legitimidade do poder.

O bonapartismo sem Bonaparte ou, como diria Gramsci, o cesarismo sem Cesar (Gramsci, 1989, p. 64) ao expressar e produzir, a partir de 1964, a autonomia do Estado em relação à sociedade por meio das Forças Armadas, como condição de resolução da crise de hegemonia dos diferentes setores da burguesia frente às mobilizações populares por reformas no País, propiciou diferentes graus de autonomização do aparelho de segurança no interior do Estado, com relativa perda de controle por parte dos militares à frente da Presidência da República.

Com efeito, tal perda de controle colocava todos os problemas relativos à legitimidade do regime militar, cuja implicação maior aos olhos dos setores castelistas, ligados a Escola Superior de Guerra (ESG), era o de colocar em risco a Segurança Nacional e Hemisférica, bem como a modernização capitalista em curso, no âmbito da aliança estratégica (econômica e militar) com os Estados Unidos, no contexto da Guerra Fria.

As alianças, que precederam o golpe de estado, estabelecidas entre empresários e militares consubstanciadas, especialmente, nas articulações realizadas pelo Instituto Brasileiro de Ação Democrática (IBAD) ${ }^{2}$ e Instituto de

\footnotetext{
${ }^{2}$ O Instituto Brasileiro de Ação Democrática (IBAD), criado em maio 1959, reunia um grupo de empresários conservadores que pretendiam defender a democracia. Seus fundadores foram Lauro Beer, Barthelemy Beer, Lauro Barros, Odemir Faria Barros e Aloísio Hanner. Carlos Lacerda, à época governador da Guanabara, apoiou a criação da IBAD. O grupo fundador foi composto pelo Marechal Inácio de Freitas Rolim, instrutor da Escola Superior de Guerra, do empresário Jorge Behring de Mattos, presidente do Conselho Superior das Classes Produtoras (CONCLAP) e da Associação Empresarial Centro de Indústrias do Estado da Guanabara, do Empresário G. Borghoff, da Associação Comercial do Rio de Janeiro e da Federation of the American Chambers of Commerce e por Ivan Hasslocher, integralista, diretor geral que realizava a relação com a Agência Central de Informações dos Estados Unidos para o Brasil, Bolívia e Equador (CIA). O IBAD, considerado uma organização anticomunista, que agia a partir de relações com a CIA no Rio de Janeiro, estabeleceu relações políticas com organizações paramilitares: Movimento Anticomunista (MAC), Movimento Democrático Brasileiro (MDB), a Organização Paranaense Anticomunista (OPAC), a Cruzada Libertadora Militar Democrática, Centro Dom Vital, liderada por Gustavo Corção, intelectual católico de extrema direita que mantinha relações também com a organização de direita Opus Dei. O Instituto agia em sintonia com a Ação Democrática Parlamentar (ADP), dirigida pelo proprietário rural e deputado udenista baiano João Mendes, e o Instituto Democrático Brasileiro, presidido pelo deputado do PDC Gladstone Chaves de Mello. O IBAD constituiu relações com empresários, militares, funcionários em cargos dirigentes do Estado, estudantes. Influenciou sindicatos, organizações que representavam a classe média, governos e os legislativos. Além disso, coordenou suas ações com o Instituto de Pesquisa e Estudos Sociais (IPES). (Dreifuss, 1987, p.101-105)
} 
Pesquisas e Estudos Sociais (IPES) ${ }^{3}$ tinham como objetivos estratégicos a promoção do capitalismo, notadamente, a partir dos interesses do capital transnacional, em associação com os empresários brasileiros, o que supunha o desencadeamento de implacável combate ao comunismo.

A hegemonia construída junto ao empresariado, ao grande capital e às classes medias, sustentou a derrubada do governo João Goulart para derrotar as reformas e a organização de diferentes setores de trabalhadores no País. Esteve apoiada em um constructo ideológico e político que se ancorou no ideário das Forças Armadas movido pela suposta ameaça da Guerra Total e Global, fundamento das ideias construídas, no âmbito da ESG, acerca da Segurança Nacional e do Desenvolvimento, consideradas indissociáveis. A compreensão sobre a natureza da Guerra e da Segurança Nacional (interna e externa à nação) deu origem às preocupações com a identificação da presença do inimigo interno como expressão da ação comunista. Tais fundamentos estiveram indelevelmente associados às referências e às práticas políticas dos militares. Mas, se a perseguição aos opositores do regime estava legitimada pelas supostas ameaças à Segurança, a exacerbação da violência colocava em questão, aos olhos de setores das Forças Armadas, a legitimidade do próprio Estado de Segurança Nacional e, por conseguinte dos padrões alcançados de desenvolvimento capitalista.

Por tais razões a liberalização foi declarada como necessária.

Golbery do Couto e Silva, quando tratou da "sístole e diástole" dos Estados, lançando mão dos principais fundamentos ideológicos da Doutrina da ESG e partindo de referências à dialética operou três movimentos interpretativos. $O$ primeiro o de naturalizar o processo de descentralização, posto que nasceria ele,

\footnotetext{
${ }^{3}$ O Instituto de Pesquisas e Estudos Sociais (IPES) foi criado em novembro de 1961 como uma organização apartidária, com objetivos educacionais e cívicos, dirigido por executivos de empresas, profissionais liberais, professores e técnicos, com o apoio da imprensa, estava voltado para o estudo e soluções dos problemas nacionais. Os objetivos enunciados se constituíam na contraface de uma campanha política, ideológica (guerra psicológica) e militar em benefício de uma organização que tinha ao mesmo tempo atividade pública e clandestina. Vale observar que publicamente o IPES pretendia difundir a compreensão dos empresários sobre as reformas defendidas por João Goulart e pela esquerda, apresentava-se como uma organização apartidária, com objetivos educacionais e cívicos voltados à defesa de reformas moderadas no plano político e econômico. Entretanto a face não pública da instituição estava voltada a uma campanha política, ideológica e militar visando a combater e, depois, desestabilizar e derrubar o governo João Goulart. O IPES funcionava como um centro estratégico enquanto o IBAD como uma espécie de unidade tática. Ambos articulavam outras entidades de natureza similar. Observe-se que as duas instituições estabeleciam relações com membros da Escola Superior de Guerra difundindo o anticomunismo que marcava e definia o posicionamento das Forças Armadas no contexto da Guerra Fria (Dreifuss, 1987, p. 162-172)
} 
inexoravelmente, da centralização. Inversamente, a chamada descentralização abrigaria elementos intrínsecos da centralização, "verso e anverso de um mesmo processo único" (Silva, 1981, p.18). Centralização e descentralização seriam apresentadas como tese e antítese em torno das quais a maioria dos estados nacionais realizaria movimento pendular com ganhos e perdas nos dois sentidos. A existência dos governos militares seria, de pronto, legitimada por tal interpretação, correspondendo a uma espécie de fase inelutável da vida dos estados. Um segundo aspecto pretendia esvaziar a natureza do Estado construído com os governos militares, a saber: o de suposta ausência de intencionalidade da revolução de 64 em operar a referida centralização que, resultando de um processo inconsciente, teria ensejado o fortalecimento da inércia da máquina administrativa, também naturalizada no processo discursivo. Valendo-se de Max Weber, o general Golbery procura demonstrar que a centralização traz consigo o fortalecimento da burocracia e, em decorrência, sua autonomização aumentando a entropia do sistema, risco para as sociedades pós-industriais do Ocidente.

O discurso sobre a burocracia abrigava as preocupações com a extraordinária força do Serviço Nacional de Informações, cuja autonomia não tinha, à época, paralelo com outras democracias $O$ órgão, sem qualquer controle institucionalizado do executivo ou do legislativo, era responsável pela segurança interna, informações estratégicas e operações especiais, tendo para isso seus próprios agentes. Detinha o monopólio do treinamento avançado da inteligência e tinha um bureau em cada Ministério. O chefe do SNI era um ministro de Estado e membro do Conselho de Estado podendo ter acesso ao presidente. (Stepan, 1987, p. 29-36).

Mas o discurso de Golbery ao se referir aos empecilhos criados por uma difusa burocracia que ganhara autonomia, guardava relação também com as práticas de outras organizações de inteligência e repressão que nasceram entre 1967 e 1972: Centro de Informações do Exército (CIE), Centro de Informações da Aeronáutica (CISA), Operação Bandeirantes (OBAN) nascida em São Paulo, Centro de Operações de Defesa Interna (CODI) - integrava a OBAN e, por não ter agentes próprios, se valia daqueles do Destacamento de Operações Internas (DOI) estabelecendo uma cadeia de comando paralelo com o CIE e o Ministério do Exército. Entre 1973 e 1975 as operações realizadas pelo DOI se tornaram clandestinas no interior do próprio governo mesmo depois da derrota da guerrilha. 
No caso do Brasil, após o auge da centralização na década de 70 , teria se desencadeado, para Golbery, o natural nascimento de "tensões freadoras". No âmbito das Forças Armadas, tais tensões, poderiam representar forte ameaça aos militares brasileiros em função de um possível afastamento dos chamados setores moderados e da possibilidade de fragmentação das Forças Armadas.

Quando Ernesto Geisel iniciou o processo de abertura conhecia a dimensão das resistências de uma parte dos militares à chamada distensão, os que Golbery chamou de "revolucionários legítimos" ou "linha dura". Mas temia, sobretudo, o avanço das forças de oposição, especialmente os chamados subversivos de esquerda.

Com efeito, tais razões explicam a estratégia do governo de realizar ações de contenção ou de contra-ataque para desarticular a oposição visando a desencadear uma progressiva ação liberalizadora associada a uma forte rigidez no campo econômico. (Silva, 1981, p. 29) que poderia ser superada pela participação dos diferentes setores da burguesia nos processos de decisão do governo e do Estado brasileiro. O ex-integrante da ESG de forma coerente com a Doutrina da Escola e, de forma geral, com os princípios do pensamento das Forças Armadas, tratava a democracia, também nesse caso, de maneira instrumental. A chamada distensão deveria abrir as estruturas do Estado para que os vários setores do empresariado pudessem conduzir a economia nacional e negociar seus interesses maiores.

Dizia ele:

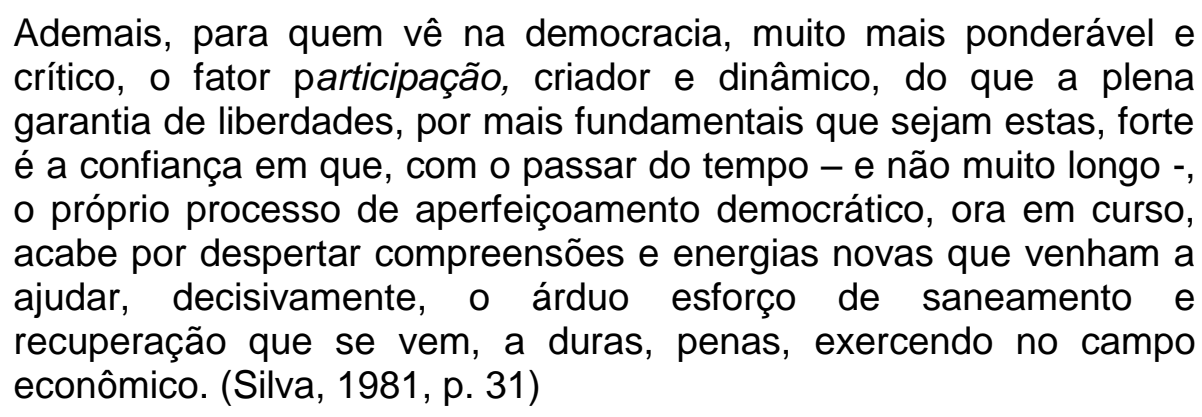

No mesmo sentido apontava a necessidade de descentralização do campo econômico para o que seria necessária a criação de uma correlação política que fosse favorável à preservação dos fundamentos da economia capitalista naquela conjuntura. 
Para tanto, cuidar-se-á de consolidar e, se possível ampliar as próprias forças, mantendo sempre dissociada a frente oposicionista, já agora, também, pelo atendimento privilegiado das pretensões deste ou daquele partido ou grupo, em detrimento dos demais. $E$ isso será tanto mais exequível quanto mais nossos propósitos, sinceros, de liberalização democratizante incluam muitas das aspirações de outros partidos ou grupos, de maior afinidade conosco e cuja aliança ou apoio poderá vir a ser alcançado, numa hábil e esclarecida manobra de cooptação por partes. (Silva,1981, p.34)

Assim se a chamada abertura política pretendia, de forma singular, frear a ação dos aparatos de segurança e ampliar determinadas liberdades, não é menos verdadeiro que pretendia fazê-lo sem reformar as instituições do Estado ou perder o controle sobre ele. Tal processo ensejou a dialética entre concessões do regime e abertura da sociedade.

As expectativas de garantia dos direitos de liberdade, dos direitos políticos e dos direitos sociais mobilizou e impulsionou a organização de diferentes setores da sociedade brasileira, visando a formular propostas, programas, reivindicações e instituindo diferentes práticas democráticas.

Uma das áreas onde a criação política pela instituição de direitos destacou-se foi a da Educação. Herdeira de um lugar instrumental nas políticas levadas a efeito durante os governos militares, no contexto das dinâmicas de expansão do capitalismo foi o polo do conflito entre diferentes concepções sobre o Estado, a sociedade, o desenvolvimento, a cultura, os direitos e a democracia durante o processo constituinte.

Entender como tal processo se estabeleceu e se desenvolveu no transcurso da Constituinte se constitui em nosso objeto de estudo $O$ objetivo desta tese de doutoramento foi compreender como a Educação, considerada um dos pilares necessários à política de Segurança e Desenvolvimento Nacional conduzida pelos militares, se torna um direito, no desenrolar do processo constituinte, em meio a uma profunda crise do Estado, a partir da participação, da mobilização, e da ação de um conjunto de sujeitos, representantes de diferentes setores da sociedade civil, que não apenas os parlamentares eleitos por suas respectivas agremiações partidárias.

Procurei identificar a configuração desse direito no processo de sua construção, isto é, quando as pluralidades heterogêneas dos discursos dos sujeitos manifestaram seu caráter dinâmico coincidindo, se chocando ou se tornando 
convergentes. Nesta perspectiva ganharam realce os silêncios que conferiram opacidade à memória, o registro e os projetos políticos com propostas contrastantes, ambivalências, dissensos, consensos, pactos e rupturas que se estabeleceram em circunstâncias históricas específicas. Neste contexto o direito à educação se definiu no âmbito do conflito entre o público e o privado entre os anos de 1985 a 1988.

O discurso atemporal dos militares sobre o lugar da Educação na construção de uma nação inventada e imaginária instituiu a mística da reciprocidade ao operar a identificação entre o discurso e o real, tanto para legitimar as práticas violentas de um Estado Nacional que opunha direito e necessidade, como para tornar esta oposição fundamento das desigualdades sociais, regionais e culturais, como resultado da opção pelo modelo de desenvolvimento capitalista.

Os debates e iniciativas que antecederam à instalação do Congresso Constituinte deram início a uma experiência de organização, mobilização e ação que interferiu no intenso movimento de elaboração dos anteprojetos, envolvendo além dos representantes os representados, isto é, os diferentes setores sociais que se organizaram e se prepararam para interferir nas decisões sobre a política pública de educação, no contexto de um processo de participação mais amplo que se verificou em outras áreas, de diferentes formas. Foi o caso da Confederação Nacional dos Bispos do Brasil e de outros setores que não tiveram oportunidade de fazê-lo durante os governos militares, assim como as entidades que se organizaram no Fórum da Educação na Constituinte e em Defesa da Escola Pública e Gratuita.

Vale registrar que os parlamentares de primeiro mandato que integraram a Constituinte tinham ânsia de participar, também pela condição da primeira experiência parlamentar buscando, sob a bandeira da renovação, estarem próximos de todos os setores da sociedade civil.

O debate foi intenso, pois o desafio era o de, em tempo e espaço determinados, proceder à elaboração e votação do texto constitucional, assegurando-se a participação social prevista regimentalmente. Mas foi na conjuntura da chamada transição democrática que se encontram alguns dos elementos explicativos para compreender a dinâmica das contradições e dos conflitos. Os parlamentares que haviam sustentado a ditadura militar seguiam 
pretendendo falar pela nação. Uma nação coesa, homogênea e fixa que deveria sustentar uma transição tutelada.

Entretanto, os porta-vozes da nação imaginada, além de se defrontarem no espaço público do Congresso Constituinte com os seus próprios pares, de diferentes orientações políticas, se viram diante de sujeitos que representavam forças sociais reais, portadores de uma experiência social específica e, em muitos casos, se mostrando publicamente. Os debates e decisões sobre a Educação ocorreram no contexto das expectativas do que deveria ser reafirmado ou negado em relação à legislação e às instituições que estruturavam o Estado nacional durante o período militar. Sob esse prisma se definiu nossa baliza cronológica. Embora a Constituinte tenha sido iniciada em 1985, no contexto do governo da Aliança Democrática, e instalada nos primeiros meses do ano de 1987 , foi necessário retroagir ao começo da distensão política para decifrar alguns dos dilemas do processo Constituinte em 1988, tornando possível melhor compreensão do objeto desta pesquisa.

Nessa medida, o trabalho de investigação histórica se desenvolve a partir do discurso político, considerando-o como aquele que instaura e dá sentido às formulações jurídicas. Lembro Raymundo Faoro:

A constituição em sentido social e a constituição em sentido jurídico constituem as duas faces da constituição política. Uma constituição não é, deste modo, a mera síntese das condições reais do poder, nem um conjunto esparso de regras jurídicas. Da interação desses dois fatores, dirigidos pela vocação dos destinatários do poder de controlá-lo, se afirma a essência da constituição, inadmissível, portanto, como maquiagem das pessoas ou dos grupos que se assenhoreiam da força. (Faoro, 2007, p.178)

Esta compreensão fez com que esta pesquisa tenha tomado como referência fundamental o discurso político dialogando com campos distintos da produção historiográfica como a história das ideias e a história dos conceitos. Não obstante não tenha me ocupado da história dos conceitos em discussão no debate sobre educação na Constituinte, alguns dos problemas envolvidos nesse campo de estudo foram considerados relevantes para efeito da análise do discurso. O primeiro deles diz respeito a como determinadas noções se relacionam com o tempo presente, mas também com as dimensões temporais do passado e do futuro, registrando, no âmbito da linguagem, as dimensões histórica e antropológica que marcam todo ato de linguagem. (Koselleck, 2012) 
Este problema desafiou a compreensão de como as ideias e noções presentes nos diferentes discursos dos sujeitos - parlamentares ou representantes de entidades da sociedade civil - mobilizavam e entrelaçavam imagens e significados do passado, projetando o futuro.

Dentre as representações ideológicas mais expressivas destacamos aquelas que articulam a relação entre educação e nação evocando, de diferentes maneiras, o ideário dos militares brasileiros que estiveram à frente do Estado entre 1964 e 1985.

Além disso, é preciso destacar que no caso das formulações de um texto constitucional, a interpretação da reelaboração de significados e representações é tanto mais necessária se consideramos as dinâmicas e as especificidades do processo de formulação de uma constituição, qual seja a de considerar os textos das constituições anteriores e a tendência de considerá-los, ressignificá-los ou reconfigurá-los em uma nova conjuntura. A retomada das formulações, em especial, da Constituição de 46 expressava o empenho, de muitos setores, em refletir sobre a última constituinte resultante de um período democrático no Brasil, tomando-a como referência mais próxima.

Nessa atmosfera os setores que tinham apoiado e sustentado os governos militares também evocaram orientações e formulações presentes nas constituições de 1967 e 1969.

Tal constatação, identificada nos debates da Constituinte, nos conduziu ao exame dos textos constitucionais de 1934, 1937, 1946, 1967 e 1969 relativos à educação. Ao fazê-lo, também foram retomadas, em alguns casos, interpretações e reinterpretações realizadas tanto pelos parlamentares como pela sociedade civil.

Esta questão encontra-se intimamente relacionada com a natureza polissêmica dos conceitos, das noções e definições jurídicas mobilizadas, na medida em que incorporam sentidos das situações político-sociais em que se inserem, em determinadas conjunturas históricas. (Ibidem)

Os artigos da Constituição de 1988 evocam esses sentidos e se tornam campos de disputas de significados, antecipando (no presente) ou projetando (no futuro) escolhas e conflitos políticos, razão pela qual as análises das dinâmicas do discurso ideológico se impuseram. 
O percurso interpretativo foi construído em função da constatação de que boa parte dos trabalhos consultados centraram suas pesquisas no exame dos direitos consagrados na Constituição ou os conflitos entre o público e privado, como processos relativamente independentes. No primeiro caso, a ênfase foi dada à garantia da gratuidade do ensino público oferecido em estabelecimentos oficiais vivida como vitória dos setores populares.

É o caso do trabalho de Oliveira (1995). Estudando o Direito à Educação no Brasil - a partir de uma análise histórico-comparativa da Constituição de 1988, da análise jurídica do texto e da aplicação da Carta Magna na prática jurídica - 0 autor, examinando as constituições elaboradas no Brasil desde o Império, demonstra a singularidade da Carta no que diz respeito ao direito à educação. Destaca, em linhas gerais, a primazia do estado no dever de educar; a gratuidade do ensino público nos estabelecimentos oficiais, a perspectiva de progressividade de acesso à educação pública nos diferentes níveis e modalidades de ensino e o acesso ao ensino fundamental, obrigatório, público e gratuito, como direito público subjetivo.

No segundo, a destinação dos recursos públicos para escolas comunitárias, assistenciais e filantrópicas ou a oferta de bolsas de estudo para o ensino fundamental e médio, tomada como uma vitória dos setores privatistas. Os trabalhos consultados apontam que é em torno deste confronto que se organizaram os partidos e os representantes da sociedade civil.

A esse respeito vale retomar o problema posto pelo trabalho de Pinheiro (1991) no que se refere ao Estado, como poder público, no âmbito dos conflitos travados no interior da Constituinte.

Considerando os embates em torno dos destinos da educação como uma problemática mais ampla em relação ao papel do estado na sociedade brasileira, no que se refere à delimitação da esfera pública e privada, a autora indica que a função do Estado, como poder público, não pode ser avaliada em função apenas de sua maior ou menor presença, pois sua natureza poderia estar associada a interesses privados.

Reconhecendo o forte e histórico papel desempenhado pelo Estado brasileiro no desenvolvimento econômico, a autora destaca sua natureza notadamente 
autoritária e privatista para apontar a necessidade da existência de uma esfera pública desenvolvida, isto é comprometida com os interesses públicos.

Propondo-se a entender o conteúdo dos artigos da Constituição relativos à educação e quais os setores que foram vitoriosos ou não no processo constituinte, a autora situa os conflitos a partir de um campo mais amplo de concepções ideológicas e políticas sobre o papel do Estado, campo esse que pretendeu, vigorosamente, tornar sua posição predominante na sociedade. Ressalvando as especificidades do caso educacional - posto que não estava em questão apenas a disputa dos fundos públicos e as condições de prestação dos serviços educacionais, mas as questões ideológicas relativas à concepção de educação envolvidas no debate - a autora identifica o conflito entre o público e o privado como intrínsecos à gestão da educação brasileira e como a questão primordial na Assembleia Nacional Constituinte à qual resumiu-se a disputa entre os vários segmentos sociais.

Aponta que a plataforma do ensino privado, embora aludindo ao discurso liberal, em verdade igualou o princípio da liberdade de ensino à existência da livre iniciativa no campo empresarial e procurou redefinir o conceito de educação pública pretendendo torná-lo mais abrangente com o fito de conquistar o espaço e os recursos públicos.

A singularidade do trabalho de Pinheiro, a partir da perspectiva sociológica, está em evidenciar que tal disputa se deu tanto no campo político como semântico visando a criar as condições para que a iniciativa privada atingisse seus objetivos a partir de uma forte aliança entre as escolas confessionais e leigas.

Para tanto realiza a identificação dos sujeitos e seus interesses no movimento dos debates e elaboração de propostas durante as diferentes fases da Constituinte. A análise desse processo constitui-se em uma das maiores contribuições da pesquisa que suscitou diversas questões para o presente trabalho.

Outra pesquisa examinada foi a de Renato Soares (1990) que tratou das principais lutas das entidades ligadas à questão da educação, bem como de seus projetos educacionais de caráter nacional; identificar e analisar o que chamou de expectativas macro educacionais, tanto das chamadas forças conservadoras quanto progressistas e examinar em que medida correspondiam às propostas gerais das 
classes sociais no País. Por fim, o trabalho interpretou as conquistas consolidadas no texto constitucional.

A análise, reconhecendo no processo da Constituinte vitórias parciais dos setores progressistas, explica seus resultados em função da manutenção do controle do Estado pelas classes dominantes e pela natureza do processo de transição no Brasil, cujas características não permitiram uma composição política capaz de expressar a vontade do conjunto da sociedade.

De acordo com o autor, às elites não interessava a democratização social da educação, antes pretendiam manter a instituição escolar como um instrumento de controle social. Tratava-se de assegurar uma escola capaz de "controlar as mentes" evitando a democratização da gestão do ensino público e privado. A condição da escola, como um aparelho ideológico do Estado, estaria condicionada pelas condições socioeconômicas do país.

Sob essa perspectiva analítica o autor indica que a Constituição de 1988 enfeixou um conjunto de paradoxos: assegurar, recursos para alfabetização, nas Disposições Constitucionais Transitórias, mas manter o latifúndio e a concentração de renda como fonte de reprodução do analfabetismo; ampliar a perspectiva de oferta do Ensino Médio gratuito em escolas públicas em oposição às escolas privadas que assegurariam à elite a formação necessária para chegar à Universidade. Os setores conservadores teriam, na opinião do autor, se recusado a democratizar a gestão das instituições educacionais ao mesmo tempo em que mantiveram as condições de propriedade de canais de rádio e televisão e recusaram a possibilidade de controle social sobre a produção de materiais didáticos utilizados nas escolas públicas.

Além disso, aponta que o conflito entre o público e o privado resultou na apropriação privada de recursos públicos, em particular do salário-educação.

A interpretação é realizada a partir de um conjunto de referências necessárias à construção do que considera ele uma educação progressista. Em termos gerais tal projeto deveria estar apoiado em pelo menos quatro medidas: distribuição de renda, concretização da reforma agrária, auditoria da dívida externa e o fortalecimento, ampliação e consolidação da democracia. 
Sobre o processo constituinte merece ainda destaque o trabalho de Junior (1998) que trata, em particular, da atuação do Partido dos Trabalhadores na Constituinte. Tomando como problema teórico mais amplo a dimensão educativa da ação partidária, bem como o papel do intelectual nos partidos políticos e na sociedade, o autor analisa tanto as identificações e rupturas do programa do PT com o pensamento socialista clássico quanto o sentido da chamada perspectiva estatizante, entendida pelo autor como a total negação do ensino privado.

Indicando que a construção da proposta educacional do partido se estabeleceu a partir de opções frente às contradições entre ensino religioso e ensino laico; vinculação ou não verbas para o ensino público, destacou o dilema central referente ao caráter público ou privado da educação e, ainda sobre a natureza do público, não considerado como educação estatal na percepção do autor.

Outro estudo consultado foi o trabalho sobre diretrizes da política de financiamento da educação brasileira de Farenzena (2001) no qual há um capítulo dedicado à Assembleia Constituinte de 1987-1988. A autora, examinando todas as fases do processo (subcomissão e comissões) abordou a questão do financiamento a partir dos temas: descentralização, regime de colaboração, controle público e social da gestão financeira, estabilidade relativa do volume de recursos disponíveis para a educação, hierarquização da alocação de recursos financeiros, objetivação de critérios para a fixação e distribuição de recursos.

Reconhecendo que a chamada Constituição Cidadã não chegou a ultrapassar alguns limites históricos em relação à repartição de recursos de poder político e, em decorrência, a "cristalização de relações sociais desiguais" (Farenzena, 2001, p.116) considera, por outro lado, que ampliou os direitos de cidadania o que teria criado melhores condições de luta por sua efetivação e ou ampliação.

Os direitos em relação à educação foram compreendidos pela autora como possibilidade de realização da inclusão de crianças, jovens e adultos seja pela expansão ou universalização de obrigações. Observe-se também que a experiência de participação da sociedade e às conquistas constitucionais foram percebidas como oportunidade de fortalecimento da organização dos movimentos sociais para normatizar as definições estabelecidas visando à sua concretização. 
É preciso destacar a obra de Cunha (2009) que, ao tratar da educação, do estado e da democracia no Brasil, dedica um capítulo a análise do processo constituinte. $\mathrm{O}$ autor demonstra como o texto constitucional expressou os diferentes movimentos do Centrão no sentido de deslocar a responsabilidade do Estado pela educação uma vez que foi definida como sendo também da família, devendo, ainda, ser promovida com a colaboração da sociedade. Demonstra ainda como as instituições privadas foram resguardadas de obrigações como a valorização do magistério e a gestão democrática, princípios previstos apenas para o ensino público.

O autor demonstra as várias garantias constitucionais que asseguraram tanto o acesso aos fundos públicos como a isenção fiscal para escolas leigas e confessionais sem deixar de referir-se, contudo as conquistas que representaram a obrigatoriedade do ensino fundamental gratuito para todos em estabelecimentos oficiais.

Foram consultados também o conjunto de artigos incluídos em Fávero (2005) como resultado do Seminário da Associação Nacional de Pós-Graduação e Pesquisa em Educação (ANPED). ${ }^{4}$

O percurso interpretativo foi construído em função da constatação de que boa parte dos trabalhos consultados centraram suas pesquisas no exame dos direitos consagrados na Constituição ou os conflitos entre o público e privado, como processos relativamente independentes.

Buscando interpretar e compreender o processo de abordagem das questões, o movimento de construção das formulações e a apresentação das propostas nos diferentes espaços de elaboração e decisões - Comissões e Subcomissões da Constituinte - a partir do olhar do historiador, me detive menos na análise isolada dos temas afetos à garantia de direitos ou ao conflito entre público e privado em benefício da compreensão do movimento das discussões que ocorreram, especialmente, no âmbito da Subcomissão de Educação, bem como das interferências recíprocas que deram origem ao corpo dos diferentes substitutivos

\footnotetext{
${ }^{4}$ Esta publicação resultou de um seminário, proposto pelo Grupo de Trabalho "Estado e Política Educacional" da ANPED, que congregou pesquisadores que haviam elaborado trabalhos sobre educação nas constituintes brasileiras. O Seminário realizou-se em dezembro de 1992 e contou com o apoio da Capes e INEP/MEC.
} 
interpretando, mais especificamente, como as dinâmicas de participação permitiram que a vitória dos setores liberais e privatistas não tornasse inviável o direito à educação às maiorias sociais. Referimo-nos aqui ao fato de que as garantias constitucionais, sem precedentes na história da República, tornavam possível a disputa pela aplicação dos recursos vinculados à Educação na educação pública. A sociedade, em particular, os setores excluídos do acesso à escola, depois da Constituição passaram a ter a lei como ponto de apoio para continuar a lutar pelo direito à educação de qualidade, na escola pública, com recursos públicos, gerida a partir de princípios democráticos.

Do exame das pesquisas que deram subsídios documentais às obras citadas, desbravando os arquivos da Constituinte - seja quanto ao papel dos partidos ou quanto à participação da sociedade civil - ficou, enfim, a questão de entender como as propostas comprometidas com o direito à educação condicionaram e foram condicionadas pelo debate, pelas propostas e pelas representações relativas ao público e o privado. Foi este problema que conduziu ao exame das Atas da Subcomissão de Educação, Cultura e Esportes. Elas se constituíram em espaços de realização das audiências públicas e recebimento das diferentes propostas da sociedade civil que se envolveu no processo. Esta fase integrou um processo de trabalho previsto no Regimento Interno. Entre $1^{\circ}$ de fevereiro de 1987 e 5 de outubro de 1988, quando da promulgação da Constituição, os trabalhos foram organizados em sete etapas subdivididas em vinte e cinco fases que representam a documentação produzida-deliberada no processo e são registradas em ordem alfabética. ${ }^{5}$

$\mathrm{Na}$ etapa Preliminar (1) foi definido o Regimento Interno da Assembleia Nacional Constitucional e abertos canais para recepção de sugestões de cidadãos, de constituintes e de entidades da sociedade civil. O trabalho de cada uma das vinte e quatro Subcomissões Temáticas (2) pode ser conhecido a partir dos documentosfases: $A$ - Anteprojeto do Relator; B - Emenda ao Anteprojeto do Relator e C Anteprojeto da Subcomissão. Conduzindo reuniões, simultaneamente, cada uma das oito Comissões Temáticas (3) materializou as contribuições e discussões em

\footnotetext{
${ }^{5} \mathrm{Na}$ transição da ditadura militar para uma nova ordem civil a Emenda Constitucional n. 26, de novembro de 1985, convocou a Assembleia Nacional Constituinte. O ano de 1986 foi marcado, institucionalmente, pelas eleições legislativas federais e pela elaboração do Anteprojeto Constitucional.
} 
quatro documentos-fases: $E$ - Emenda ao Anteprojeto da Subcomissão na Comissão; F - Substitutivo do Relator; G - Emenda ao Substitutivo e $\mathrm{H}$ Anteprojeto da Comissão. O último documento de cada Comissão Temática foi encaminhado à Comissão de Sistematização (4) que, por sua vez e responsabilidade, constituiu-se em sete diferentes documentos-fases: I - Anteprojeto de Constituição; J/K - Emendas de Mérito e de Adequação ao Anteprojeto; L Projeto de Constituição; $M$ - Emendas (1P) de Plenário e Popular; $N$-Substitutivo 1 do Relator; $O$ - Emenda (ES) ao Substitutivo 1 e P - Substitutivo 2 do Relator. A etapa Plenário (5), realizada de 7 de janeiro a 2 de setembro de 1988, produziu os documentos-fases: $Q$ - Projeto $A$ (início $1^{\circ}$ turno); $R$ - Ato das Disposições Transitórias; $S$ - Emenda (2P) de Plenário e Emendas do Centrão ${ }^{6} ; T$ - Projeto $B$ (fim do 1ㅜ; início $2^{\circ}$ turno); $U$ - Emenda (2T) ao Projeto $B$ e $V$ - Projeto $C$ (fim $2^{\circ}$ turno). No penúltimo passo, coube à Comissão de Redação (6) as fasesdocumentos $W$ - Proposta exclusivamente de redação e $X$ - Projeto $D$ - redação final. A fase $Y$ - Epílogo (7) dá-se com a promulgação da Constituição. (Brasil, Assembleia Nacional Contituinte, 1993; Oliveira, 1993; Lima; Passos; Nicola, 2013)

O processo no interior da Constituinte abriu espaço para que a participação dos sujeitos ocorresse não apenas em torno da reivindicação de direitos, mas da colocação do direito e do exercício da cidadania em movimento, a partir da capacidade de organização, formulação e proposição dos sujeitos envolvidos. Esta percepção está na origem do interesse pelas Atas da Subcomissão embora seja preciso destacar que nem todas as discussões, pactos e acordos seguiram a dinâmica das discussões previstas nos trabalhos das Subcomissões e das Comissões do Congresso Constituinte.

Destaque-se que o exame das atas - a principal fonte documental da pesquisa - foi mais detalhado na Subcomissão de Educação e, em menor grau na Comissão VIII, em função do exame de nosso problema inicial. Tanto no caso da Comissão VIII quanto da Comissão de Sistematização a ênfase maior foi no exame das diversas versões dos anteprojetos - uma das duas fontes do corpus documental desta pesquisa de doutoramento - tomando, neste caso, as Atas como ponto de apoio.

\footnotetext{
${ }^{6}$ Reforma do Regimento Interno, de 10 de novembro a 5 de janeiro de 1988.
} 
Esse percurso analítico foi estruturado em cinco capítulos. O primeiro capítulo - As aventuras e as desventuras do processo de transição no Brasil - trata do processo de desmilitarização do Estado brasileiro, a partir de 1974 e do processo de mobilização de diferentes setores da sociedade brasileira pela redemocratização. Também analisa a vitória da Aliança Democrática e do processo de Convocação da Assembleia Nacional Constituinte e aborda o debate sobre a natureza, o alcance e a efetividade da Constituição entre os Constituintes, em diferentes momentos dos trabalhos da Subcomissão e das reuniões da Subcomissão de Educação. Além disso, identifica o lugar da Educação no imaginário nacional.

O capítulo 2 - O público e o privado na educação - aborda as políticas educacionais desenvolvidas pelos governos militares, tornando a Educação um instrumento do desenvolvimento capitalista no país e um campo de investimento da iniciativa privada. À análise da herança institucional e legal deixada pela Ditadura seguiu-se o exame das discussões acerca da destinação dos recursos públicos desde a análise tanto do projeto Afonso Arinos e da Carta de Goiânia, documento produzido, tendo como base os debates realizados pela Conferência Brasileira de Educação (CBE). Também ganharam ênfase os debates acerca desta questão nas primeiras reuniões da Subcomissão de Educação.

O Capítulo 3 - Somos todos constituintes - apresenta a Educação como questão nacional e democrática, a partir das manifestações realizadas por entidades da sociedade civil, no âmbito da Subcomissão de Educação. Discute-se ainda a educação e a cultura como centro da questão nacional democrática desde a manifestação de entidades e personalidades da sociedade civil que não estiveram diretamente ligadas ao trabalho educacional.

O Capítulo 4 - Entre o público e o privado - retoma as manifestações das entidades da sociedade civil na Subcomissão de Educação, a relação entre educação, justiça social e igualdade e as diferentes concepções e confrontos em torno da destinação dos recursos públicos. Associado à questão do financiamento foi abordado, no debate da Subcomissão, o papel do Estado e da família no que se refere ao dever de educar.

O capítulo 5 - A Constituição inacabada - apresenta as dimensões do direito à educação e a destinação dos fundos públicos nos anteprojetos que tramitaram na 
Subcomissão de Educação, na Comissão VIII e na Comissão de Sistematização até a votação em plenário, procurando desvelar por meio dos textos os conflitos que se expressavam no âmbito da Constituinte.

Por fim encontram-se as Considerações Finais que apresentam a singularidade da natureza e do sentido da Constituição de 1988, presente na atuação social e política de sujeitos que além de reivindicar propõem programas nacionais para a Educação. 


\section{1 - As aventuras e as desventuras do processo de transição no Brasil}

\section{1 - O processo de desmilitarização, o jogo das tensões sociais e a Constituinte}

O ano de 1974 marcou um ponto de inflexão no sentido da militarização do Estado e da sociedade brasileira. Desenhou-se uma crise no aparato militar expressa pela perda de controle sobre os aparatos de segurança. Setores das elites econômicas e políticas começaram a difundir a tese da liberalização, em função da repressão indiscriminada operada pelos órgãos de segurança e o perigo ao qual qualquer cidadão identificado com as ideias oposicionistas estava submetido.

A Ordem dos Advogados do Brasil (OAB), a Associação Brasileira de Imprensa $(A B I)$ e a Conferência Nacional dos Bispos do Brasil (CNBB) - não obstante as várias posições políticas de suas bases - passaram a reivindicar a premência da democratização. Não menos expressivo foi o resultado das eleições realizadas em 1974 que "surpreenderam a todos, inclusive aos estrategistas mais otimistas do MDB" (Skidmore, 1988, p. 34). O Movimento Democrático Brasileiro (MDB) aumentou de 87 para 165 o número de suas cadeiras na Câmara dos Deputados, enquanto a Arena diminuiu o número de seus deputados de 223 para 199. Como bem assinala Thomas Skidmore, "desde o início do Governo Geisel, a oposição exigia um retorno ao Estado de Direito, opondo-se à insistência do presidente em reter os poderes arbitrários promulgados com o Al-5" (Ibidem, p. 39). Além disso, o MDB ganhou o Senado ${ }^{7}$ com uma campanha centrada nos temas da justiça social e na presença estrangeira em vários setores da economia brasileira (Ibidem, p. 35). Nas palavras do autor:

O que essa vitória da oposição significava? O MDB centrou sua campanha em três temas: justiça social (denunciando a tendência de uma distribuição de renda cada vez mais desigual), liberdades civis (as violações dos direitos humanos que tanto preocupavam a crítica

\footnotetext{
${ }^{7}$ Disputando vinte e duas vagas do Senado Federal, o MDB saiu vitorioso em dezesseis estados. Foram eleitos: Adalberto Correia Sena (AC), Agenor Nunes de Maria (RN); Danton Jobim (GB), Dirceu Cardoso (ES), Evandro das Neves Carreira (AM), Evilásio Vieira (SC), Francisco Leite Chaves (PR), Itamar Franco (MG), José Gilvan Rocha (SE), Lázaro Barbosa (GO), Marcos Freire (PE), Mauro Benevides (CE), Orestes Quércia (SP), Paulo Brossard (RS), Ruy Carneiro (PB) e Saturnino Braga (RJ).
} 
da elite) e desnacionalização (denunciando a penetração estrangeira na economia brasileira). (Ibidem)

Pressionado, o governo Geisel passou a orientar uma abertura política gradual, vigiada e controlada, rumo à democracia. Em 1975, o processo foi alterado com as manifestações da imprensa acerca do assassinato do jornalista Vladimir Herzog nos porões da ditadura militar. O ocorrido levou, nos anos subsequentes, a alterações na pretendida abertura "lenta, segura e gradual". A intervenção de diferentes setores da sociedade conferiu uma dinâmica própria a este processo, que se fortaleceu até ser promulgada a Constituição de 1988. Para não perder o controle da chamada "distensão", o Estado imprimiu uma elasticidade aos mecanismos representativos, visando a cooptar os vários setores da oposição em um cenário de franca luta pela anistia, unificando a sociedade civil em processo de organização, ao qual se somou, entre os anos de 1978 e 1979, um novo sindicalismo representado pelas greves dos metalúrgicos do $A B C$, seguidas de uma série de outras de mais de uma dezena de setores profissionais em todo o país, que veio a culminar, em 1983, com a fundação da Central Única dos Trabalhadores (CUT).

Some-se a reestruturação do movimento estudantil com a reorganização da União Nacional dos Estudantes (UNE) que, desde 1977, promoveu "uma série de manifestações e passeatas, a primeira em São Paulo e posteriormente em todo país, violentamente silenciadas pela forte repressão policial" (Alves, 1984, p. 207).

Não de menor destaque foi a mobilização de setores populares em torno da luta contra a carestia das comunidades eclesiais de base e a crescente atuação da Comissão de Justiça e Paz da Arquidiocese de São Paulo, assim como de outras organizações defensoras dos direitos humanos. (Scherer; Krischke, 1987). Todos esses movimentos deixam transparecer identidades crescentemente polimorfas, de múltiplas possibilidades de combinação, revelando formas plurais de autoorganização da sociedade civil em torno de direitos ${ }^{8}$. E, sobretudo, no seu conjunto, revelavam os descontentamentos de várias ordens, imprimindo um ritmo mais

\footnotetext{
${ }^{8}$ Pensando esse momento, retomo a experiência fascinante narrada por Antonio Alves e Jorge Viana sobre os empates: "Em 1976 acontece o primeiro 'empate', organizado pelo Sindicato de Brasiléia. Grupos de trabalhadores organizados passam a se defrontar, cada vez mais, com peões de derrubadas e com pistoleiros. O movimento se espalha no vale do rio Acre. Quando Wilson Pinheiro, a principal liderança nessa fase, é assassinado em Brasiléia, no início dos anos 80, Chico Mendes iniciava seu primeiro mandato na presidência do Sindicato Xapuri." (Alves; Viana, 2004, p. 24) As cidades e a floresta estão em movimentos de resistência e transformação. Ver Antonacci (1994).
} 
acelerado ao processo de mudanças em curso, em particular no que se refere à distensão dos aparatos de segurança.

Essa transição para a democracia no Brasil, marcada por profundos conflitos, foi controlada com uma "abertura lenta, segura e gradual" projetada por Golbery do Couto e Silva e por Ernesto Geisel, à frente da presidência, visando a retomar a democracia sem ameaças à ordem econômica capitalista, manter o controle político do processo em mãos conservadoras e manter as Forças Armadas imunes a qualquer julgamento. Entretanto, em particular depois de 1977, os movimentos sociais entraram no cenário político formulando propostas voltadas à transformação do país. Experiência alimentada e que também alimentou o diálogo e a negociação, sobretudo, a partir dos anos oitenta, com os partidos de esquerda (como PCB, $\mathrm{PCdoB}$ e PT), os quais, embora tivessem diferentes experiências, programas e estruturas organizativas, mantiveram os objetivos de promover a justiça, lutar pela garantia e fortalecimento das instituições democráticas, restabelecer o estado de direito e formular propostas para as políticas públicas. Houve também o compromisso de superar o arcabouço legal e o constructo político e ideológico erigido pelos militares desde a década de 1940, fundamentos de sua ação política à frente do estado brasileiro depois do golpe de 1964, quando as instituições e programas sociais se fizeram em torno de critérios de eficiência e lucratividade, nos parâmetros do desenvolvimento do capitalismo.

A vida político-partidária brasileira ganhou maior vigor. As eleições de 1982 tiveram um forte impacto no jogo político-eleitoral, evidenciando a força do Partido do Movimento Democrático Brasileiro (PMDB) e do Partido dos Trabalhadores (PT), fundados dois anos antes, ambos interlocutores das forças de oposição que participaram ativamente na organização, no final de 1983, do primeiro comício pelas eleições diretas no Brasil, realizado no estádio Paulo Machado de Carvalho, em São Paulo. Colocava em xeque a legislação da ditadura que estabelecia a eleição do Presidente da República por um Colégio Eleitoral formado por integrantes da Câmara dos Deputados e do Senado Federal. Significava uma ruptura com os processos de escolha indireta dos presidentes da república, fortalecida por uma aliança entre setores liberais e os movimentos de esquerda, em defesa das eleições diretas, com a aprovação de uma emenda no Colégio Eleitoral. Entretanto, as 
gigantescas manifestações pelas Diretas Já!, não foram suficientes para sustar a eleição indireta.

O PMDB e outros partidos de oposição lançaram a candidatura de Tancredo Neves à Presidência da República pelo Colégio Eleitoral em julho de 1984. Para alcançar os votos necessários aliaram-se à Frente Liberal e José Sarney tornou-se candidato à Vice-Presidente na chapa passando a integrar o PMDB um dia depois do lançamento da Aliança Democrática, em 08 de agosto de 1984.

Com efeito, tal decisão demonstrava que a disputa em torno dos destinos da transição democrática seria feita intensamente no interior do PMDB. Como apontou Faoro o partido passava a fazer a transação interna nas suas fileiras para fazer a transação externa fora delas (Dias, 2008, p. 68).

Após seu lançamento, a Aliança Democrática em manifesto intitulado "Compromisso com a Nação" assumia como perspectiva o restabelecimento imediato das eleições diretas, livres e com sufrágio universal para Presidente da República, Prefeitos das Capitais dos Estados e dos Municípios considerados estâncias hidrominerais e dos declarados de interesse da segurança nacional e convocação de Constituinte, livre e soberana, em 1986, para elaboração de nova Constituição.

A não referência à condição democrática da Constituinte se justificaria em função de uma perspectiva que condicionaria todas as demais, qual seja a de uma transição ordenada a partir de um pacto de conciliação voltado à promoção da coesão nacional. (Meneguello, 1989)

O candidato da situação, Paulo Maluf, contou com o apoio de todos os setores militares na disputa com Tancredo Neves, candidato da oposição, que se foi saiu vitorioso em 15 de janeiro de 1985 recebendo 72 , 4\% dos votos contra 27,3\% de Paulo Maluf.

Ainda assim, é possível considerar que a derrota das "Diretas Já!" foi o principal movimento para a luta por uma Assembleia Nacional Constituinte (ANC) a qual acabou por ser galvanizada pelo Governo Sarney:

Assim, por ironia do destino, atestando o caráter transicional do processo, foi um líder da ditadura, embora já dela dissidente, quem terminou presidindo a última fase da transição democrática. Sarney não era da oposição, mas se adaptou ao partido de adoção e à nova 
situação. A rigor, passara a vida em adaptações sucessivas. Como a sociedade, soubera adaptar-se. Nesse sentido, era um líder político emblemático. (Reis, 2014, p.108)

Mas, vale destacar que a proposta de uma Constituinte livre, democrática e soberana para promover o reordenamento institucional do País foi apresentada com a proposta de anistia, em 1971 na chamada Carta de Recife, pelo Movimento Democrático Brasileiro (MDB). A proposta era lançada pelo chamado grupo dos "autênticos" em oposição à chamada corrente dos moderados que tinha, entre seus líderes, Tancredo Neves. (Moreno, 2012; Lyra, 2013)

A proposta de uma "Constituinte com anistia", visando o pleito eleitoral de 1974, reaparece no cenário político pelas mãos do MDB e a partir de 1977 foi definida como prioridade pelo partido. Na eleição presidencial indireta, realizada pelo Colégio Eleitoral, o candidato Euler Bentes e o candidato à vice-presidente, Aureliano Chaves, reapresentaram a proposta de uma Assembleia Nacional Constituinte e eleições diretas à presidência da República.

No mesmo ano a $O A B$, sob a presidência nacional do jurista e cientista social, Raymundo Faoro, se inseria na luta pela democratização do País rompendo com o silêncio da entidade durante os anos de maior repressão. Para ele a principal bandeira a ser defendida era a de retorno do habeas corpus considerando, não obstante, a anistia e a constituinte caminhos possíveis para a redemocratização (Rocha, 2013, p.42)

Recolocando o problema da legitimidade do poder, um conjunto de juristas liderado por Goffredo da Silva Telles Jr. subscreve a "Carta aos brasileiros" onde é reafirmado o compromisso com os ideais do Estado de Direito e estabelecida a distinção entre um governo sustentado pela força ou pelo poder.

A carta não deixou dúvidas de que só o povo pode exercer a autoridade soberana, que a ele pertence o Poder Constituinte e que, desse Poder deve emanar a constituição. O contrário configuraria, de acordo com os preceitos do Estado democrático, a usurpação do poder político.

Sob essa inspiração, diferentes setores da sociedade defenderam a bandeira da Constituinte Livre Democrática e Soberana como instrumento de criação de fundamentos constitucionais para o restabelecimento do Estado de Direito, para 
consolidação da democracia e afirmação de direitos civis, sociais e políticos a partir do debate entre as diferentes classes, etnias, homens e mulheres de diferentes gerações.

A luta pelo reordenamento institucional do Brasil nos remete ao que Ferdinand Lassalle apontou, em Conferência proferida em 1862, como uma das vertentes explicativas para a sua célebre pergunta: que é uma constituição? Buscando responder a pergunta referida, Lassalle defendeu que os problemas constitucionais não são problemas de direito, mas do poder. De tal forma que as Constituições escritas teriam seu valor associado aos chamados fatores de poder presentes na realidade social, desde que em relação a eles tenha se operado uma transformação (Lassalle, 2006).

A esse respeito, observou que:

Se não se tivessem operado transformações nesse conjunto de fatores da sociedade em questão, se esses fatores do poder continuassem sendo os mesmos, não teria cabimento que essa mesma sociedade desejasse uma constituição para si. Acolheria tranquilamente a antiga, ou, quando muito, juntaria os elementos dispersos num único documento, numa única carta constitucional. (Lassalle apud Faoro, 2007, p. 171-2)

Raimundo Faoro considera que as constituições na sociedade moderna tiveram o papel de controle contra o arbítrio. Sua eficácia dependeria da legitimidade do processo constituinte e dos mecanismos criados visando estabelecer limites políticos e institucionais imprescindíveis para a existência de um governo constitucional, do contrário não haveria controle, mas a mera distribuição do privilégio, na comandita do mando entre os beneficiários da autocracia. (Faoro, 2007, p. 177)

A expectativa das entidades e forças sociais que lutavam pela democratização era a de que a Assembleia Constituinte fosse dotada de plenos poderes para a elaboração da Constituição sendo composta de representantes eleitos especificamente para este fim. Entretanto, muitos dos setores sociais que sustentaram os governos militares se opunham à Constituinte, consideravam que 0 Congresso Nacional teria as condições necessárias para levar a efeito as modificações institucionais necessárias especialmente às relativas à Emenda Constitucional n.1 de 1969. A tese foi fortemente contestada pelos setores 
progressistas, com destaque para o forte combate travado pela OAB Nacional sob a presidência de Faoro. Para os setores que sustentaram o regime militar tratava-se de operar mudanças, mas sob seu controle político e institucional. (Rocha, 2013, p. 55-57)

O processo eleitoral por via direta foi retomado $^{9}$, nas eleições de 1985 , definindo novos prefeitos para todas as cidades do Brasil e, no ano seguinte, escolheu-se por eleições diretas a nova Assembleia Nacional Constituinte. Em mensagem ao Congresso Nacional, o Presidente da República José Sarney destaca o que representa a Constituinte:

É com a mais profunda confiança no discernimento e na vocação do povo brasileiro, para organizar-se pacificamente em regime de liberdade e justiça, que proponho a Vossas Excelências a convocação da Assembleia Nacional Constituinte, ato de coragem e fé. De coragem, porque pressupõe, por parte de cada indivíduo que constituiu a comunhão nacional, a disposição de submeter ao escrutínio da Nação, direitos e situações, quantas vezes duramente conquistadas, para vê-los conformes ao ciclo histórico que reponta no presente e se projeta em um futuro de extensão desconhecida. Ato de fé é a convicção da Constituinte, porque todos os anseios e temores do futuro repousam, afinal, na confiança que cada cidadão deposita nos sentimentos de seus irmãos, de procurarem juntos uma lei fundamental que a todos proporcione os bens necessários à vida digna, vivida em paz e liberdade. (Sarney, 1985, p. 1)

O presidente Sarney destacou também a necessidade de respeitar a lei e modificá-la:

O compromisso, antes aludido, de convocação da Assembleia Nacional Constituinte, de par com os traços de generosa confiança e incontida esperança que o exornam, singulariza-se pelo fato de estar em plena vigência uma ordem jurídica e suas instituições políticas e civis, cujo império se estenderá até o momento em que for promulgada a nova Constituição. Até lá, e sob a pena de instalar-se o caos normativo, que a ninguém aproveitaria, é necessário respeitar a lei que temos e modificá-la segundo os processos por ela própria admitida, para que a vontade de alguns não seja erigida em mandamento supremo de todos. Da inelutável necessidade de manter e operar as instituições governativas vigentes, harmonizandoas à imperiosa aspiração de instaurar outras mais livres e justas,

\footnotetext{
${ }^{9}$ A partir da reforma partidária, de 1979 , retoma-se o pluripartidarismo e, em 1980 , por meio da Emenda Constitucional no 15, são restabelecidas eleições diretas para governador e senador. 0 Decreto oㅡ 2.183 (1984) e a Emenda Constitucional no 25 (1985) restabelecem eleições diretas para presidente e vice-presidente da República; eleições diretas para deputado federal, para senador e para o Distrito Federal; eleições diretas para prefeito e vice-prefeito das capitais dos estados, dos municípios considerados de interesse da segurança nacional e das estâncias hidrominerais.
} 
resulta o texto que ora submeto à deliberação dos senhores membros do Poder Legislativo da União. Por isso nele se prevê a investidura de poder constituinte pleno nos Deputados Federais e Senadores escolhidos pelo sufrágio do povo brasileiro. (Ibidem)

Finalmente, o presidente Sarney destacou "o dever assumido com a Aliança Democrática" e, ao dizê-lo, conferiu ao cenário constituinte um estatuto partidário que, ao mesmo tempo, abraçava os compromissos da Aliança Democrática ${ }^{10} \mathrm{e}$ afastava do cenário todos os que à direita e à esquerda dele divergiam.

Em um segundo momento, foi apresentado o Relatório de Afonso Arinos de Melo Franco relativo à Comissão Provisória de Estudos Constitucionais, instituída pelo Decreto 91.450 de 18 de julho de 1985. Nesta ocasião, o presidente Sarney ressaltou que estava sendo cumprida mais uma etapa do processo de restauração democrática no Brasil, salientando que o relatório da Comissão Provisória de Estudos Constitucionais era um acervo de contribuições para reflexão dos futuros integrantes da Assembleia Nacional Constituinte, ao abarcar a contribuição de Afonso Arinos de Melo Franco, a qual contemplava sugestões dos mais diversos setores da sociedade brasileira. Afinal, o pacto ao qual o Presidente Sarney se referia estava sendo costurado com muitos, incluindo os egressos do regime militar. $\mathrm{Na}$ ocasião, destacou a relevância de se construir um "cenário pactuado", o que, como é sabido, apresentava continuidade em uma série de dimensões importantes:

A nação deve um preito de reconhecimento a todos os ilustres
membros da Comissão que, com dedicação e conhecimento,
permitiram que chegássemos a este quadragésimo aniversário da
Constituição de 46 , reiniciando o incessante caminho da busca de
um novo modelo institucional para o país.

Entre a última comissão constitucional presidida por Afrânio de Melo Franco, essa exemplar figura de devotamento ao Brasil, e a que hoje encerra seus trabalhos, presidida por seu filho, vivemos mais de meio século de crises políticas, econômicas, institucionais e sociais. Vivemos quase que permanentemente mergulhados no que ousaria chamar de crise de nossa própria identidade e de nossas inquietações cívicas.

Muitas dessas inquietações e das incertezas com que costumamos encarar o nosso próprio futuro como nação, estão seguramente refletidas nos trabalhos que hoje recebo das mãos do Presidente da Comissão.

\footnotetext{
${ }^{10}$ Articulação política constituída em 1985, entre o Partido do Movimento Democrático (PMDB) e o Partido da Frente Liberal (PFL), responsável pela candidatura e vitória de Tancredo Neves à presidência da República no Colégio Eleitoral.
} 
Elas não se esgotam no modelo teórico que imaginamos, para que possamos aparelhar o Estado, organizar a economia, disciplinar 0 Governo e consolidar os direitos dos cidadãos.

Temos de nos deter no exame de nosso próprio passado e tirar de nossa história as lições que hão de servir para balizar nosso futuro.

Mas a obra do futuro não pode ser apenas essa projeção do passado. Deve ser também e deve ser, sobretudo, o resultado do esforço de aprimoramento que temos de empreender no presente. Agora. E é isso que estamos fazendo quando, a pouco menos de dois meses do pleito de novembro, recebemos esse documento tão importante. (Sarney, 1986, p. 1).

O documento dirigido à nação deixava claros os parâmetros que deveriam direcionar a Constituinte: uma democracia que pressupunha um processo de negociação com a existência de um pacto acima dos homens, das facções e dos partidos e que criasse condições para uma convivência pacífica de todos os brasileiros, abrangendo um acordo sobre o funcionamento de instituições livres, estáveis, respeitáveis e duradouras. Um pacto que definisse os objetivos em jogo, incluindo também transformações de natureza social e econômica, com itens como crescimento, emprego e salários, ainda que se necessitasse perder a ilusão de que não haveria competição ou mesmo que não deveria haver. Nesta perspectiva, formou-se em 1986 uma comissão de "notáveis"11 a qual produziu um Anteprojeto de Constituição com 468 artigos que, apesar de publicado no Diário Oficial da União (Brasil. Assembleia Nacional Constituinte, 1986) ${ }^{12}$, não foi encaminhado à Assembleia Nacional Constituinte.

\footnotetext{
${ }^{11}$ A Comissão Provisória de Estudos Constitucionais, também conhecida como Comissão Afonso Arinos ou mesmo Comissão dos Notáveis, foi formada por Afonso Arinos de Melo Franco (presidente), Alberto Venâncio Filho, Antonio Ermírio de Moraes, Barbosa Lima Sobrinho, Bolívar Lamounier, Candido Antonio Mendes de Almeida, Celso Furtado, Cláudio Pacheco, Cláudio Penna Lacombe, Clóvis Ferro Costa, Cristovam Ricardo Cavalcanti Buarque, Edgar de Godoi da Mata Machado, Eduardo Mattos Portella, Evaristo de Moraes Filho, Fajardo José Pereira Faria, Padre Fernando Bastos de Ávila, Floriza Verucci, Gilberto de Ulhoa Canto, Gilberto Freyre, Reverendo Guilhermino Cunha, Helio Jaguaribe, Helio Santos Rosar Russomano, Hilton Ribeiro da Rocha, João Pedro Gouvea Vieira, Joaquim de Arruda Falcão Neto, Jorge Amado, Josaphat Ramos Marinho, José Afonso da Silva, José Alberto de Assumpção, José Francisco da Silva, José Meira, José Paulo Sepúlveda Pertence, José Saulo Ramos, Laerte Ramos Vieira, Luís Eulálio de Bueno Vidigal Filho, Luís Pinto Ferreira, Mário De Souza Martins, Mauro Santayana, Miguel Reale, Miguel Reale Júnior, Odilon Ribeiro Coutinho, Orlando M. de Carvalho, Paulo Brossard de Souza Pinto, Raphael de Almeida Magalhães, Raul Machado Horta, Sérgio Franklin Quintella e Walter Barelli.

12 Doravante, para as referências às Atas das Reuniões da Comissão da Família, da Educação, Cultura e Esportes, da Ciência de Tecnologia e da Comunicação, da Subcomissão de Educação, Cultura e Esportes, bem como de todos os documentos da Assembleia Nacional Constituinte de 1987 - 1988 será adotada a sigla ANC para designar a autoria.
} 
A Constituinte convocada, ainda que não fosse exclusiva - com poderes plenos - contou com a participação de uma pluralidade de grupos de pressão, abrangendo setores progressistas da sociedade civil como a Central Única dos Trabalhadores (CUT), a Ordem dos Advogados do Brasil (OAB), a União Nacional dos Estudantes (UNE), que fortaleceram o diálogo com um conjunto amplo e heterogêneo da sociedade civil.

Para o caso do debate pedagógico, destaca-se a constituição do Fórum Nacional da Educação na Constituinte em Defesa do Ensino Público e Gratuito, que veio a ser um constante interlocutor e agregador de todas as entidades representativas dos educadores no país: Associação Nacional de Educação (ANDE), Associação Nacional de Docentes de Ensino Superior (ANDES). Associação Nacional de Profissionais de Administração em Educação (ANPAE), Associação Nacional de Pós-Graduação e Pesquisa em Educação (ANPED), Confederação dos Professores do Brasil (CPB), o Centro de Estudos Educação e Sociedade (CEDES), Central Geral dos Trabalhadores (CGT), Central Única dos Trabalhadores (CUT), Federação das Associações dos Servidores das Universidades Brasileiras (FASUBRA), Federação Nacional de Orientadores Educacionais (FENOE), Ordem dos Advogados do Brasil (OAB), Sociedade Brasileira para o Progresso da Ciência (SBPC), Sociedade de Estudos e Atividades Filosóficas (SEAF), União Brasileira de Estudantes Secundaristas (UBES) e União Nacional dos Estudantes (UNE). Havia, por outro lado, um conjunto de setores que representavam o setor privado da educação, incluindo a Federação das Indústrias do Estado de São Paulo (FIESP), setores das entidades confessionais de educação e os grandes aglomerados de ensino.

Em 15 de novembro de 1986 foram eleitos 487 deputados federais, 49 senadores, aos quais se somaram 23 dos senadores eleitos em 1982, perfazendo um total de 559 parlamentares titulares. Coube a eles dar início, em $1^{\circ}$ de fevereiro de 1987, ao processo constituinte que seria concluído em 5 de outubro de 1988. Foram sete as etapas do processo para a discussão das várias questões que seriam objeto de legislação: preliminar, subcomissões temáticas, comissões temáticas, comissão de sistematização, plenário, comissão de redação e epílogo (Anexo E). Os trabalhos da Assembleia Nacional Constituinte foram distribuídos em oito comissões, cada uma com três subdivisões em subcomissões temáticas. Eram elas: 
I. Comissão da soberania e dos direitos e garantias do homem e da mulher; II. Comissão da organização do Estado; III. Comissão da organização dos poderes e sistema de governo; IV. Comissão da organização eleitoral, partidária e garantia das instituições; V. Comissão do sistema tributário, orçamento e finanças; VI. Comissão da ordem econômica; VII. Comissão da ordem social; VIII. Comissão da família, da educação, cultura e esportes, da ciência e tecnologia e da comunicação. (Soares, 1999, p.103).

A Subcomissão da Educação, Cultura e Esportes era composta por Hermes Zaneti (Presidente da Comissão - PMDB/RS), Aécio Borba (1ำ vice-presidente PDS/CE), Pedro Canedo (2ำ vice-presidente - PFL/GO), tendo por relator o senador João Calmon (PMDB/ES). Integravam como titulares da comissão, os seguintes parlamentares: Louremberg Nunes Rocha, Antônio de Jesus Bezerra de Melo, Márcia Kubitschek, Otávio Elísio, Oswaldo Sobrinho, Paulo Silva, Tadeu Franca, Ubiratan Aguiar, Flávio Palmier da Veiga, França Teixeira - todos esses pela bancada do PMDB; pelo PFL, havia os deputados Átila Lira, Cláudio Ávila, José Moura, José Queiroz, Agripino Lima, Dionísio Hage; pelo PDT, Chico Humberto; pelo PTB, Sólon Borges dos Reis; pelo PT, Florestan Fernandes; e pelo PL, Álvaro Valle. Os membros suplentes eram: pelo PMDB, Irapuan Costa Junior, Carlos Benevides, Eduardo Moreira, Felipe Cheidde, Ivo Lech, Jorge Hage, José Carlos Sabóia, José Dutra, Leopoldo Bessone, Mário de Oliveira, Maurício Nasser e Renato Bernardi; pelo PFL, Evaldo Gonçalves, Geovani Borges, Pedro Ceolin, Francisco Coelho, Eraldo Trindade; pelo PDS, Ruberval Pilloto, pelo PTB, Fábio Raunheitti; pelo PT, Gumercindo Milhomen; e pelo PL, José Carlos Coutinho. (Anexo I). ${ }^{13}$

\footnotetext{
${ }^{13}$ Sobre os titulares: Hermes Zaneti nasceu em 1943, advogado e professor, foi Diretor do Ensino Rural do Estado do Rio Grande do Sul; Diretor-Adjunto do Departamento de Educação Fundamental do Estado do Rio Grande do Sul, Presidente da Confederação de Professores do Brasil, Membro do Comitê Executivo da Confederação Mundial das Organizações de Profissionais do Ensino e Presidente do Centro de Professores do Estado do Rio Grande do Sul. Aécio de Borba Vasconcelos nasceu em 1931, agropecuarista, industrial, jornalista, radialista, professor e empresário industrial. Iniciou-se, politicamente, na União Democrática Nacional (UDN), foi viceprefeito de Fortaleza/CE (1959-1963) e deputado estadual no Ceará (1963-1967). Atuou como professor de Educação Moral e Cívica. Participou da Associação Nacional de Criadores de Bovinos da Raça Holandesa e presidiu o Lions Clube de Fortaleza. O pai, José de Borba Vasconcelos, foi constituinte de 1934 e de 1946, e deputado federal pelo Ceará de 1935-1937 e de 1946-1951. Seu cunhado Mauro Benevides foi senador pelo Ceará de 1975-1995. Seu sobrinho Carlos Benevides foi deputado estadual de 1979-1986, constituinte de 1987-1988 e deputado federal pelo Ceará de 19881995. Outro sobrinho Mauro Benevides Filho, foi deputado estadual de 1987-1991. Pedro Chaves Canedo nasceu em 1949, médico, esteve filiado ao PDS, 1981-1985; PFL, 1985-1990; PRN, 19901994; PP, 1994-1995; PL, 1995-1999; PSDB, 1999-2005; PP, 2005-. João de Medeiros Calmon nasceu em 1916, advogado e jornalista, esteve filiado a ARENA, ao PMDB, ao PDS e ao PSD. Foi presidente da ARENA/ES. Profissionalmente foi diretor do jornal Diários Associados, diretor do jornal
} 
Correio do Ceará, Fortaleza, 1938, diretor da rádios Tupi e Tamoio e da TV Tupi, Rio de Janeiro, 1955. Foi presidente da Associação Brasileira de Emissoras de Rádio e Televisão (ABERT), 1962; Membro do conselho administrativo da Associação Brasileira de Imprensa (ABI), 1963. Escreveu Duas Invasões [1966], O Livro Negro da Invasão Branca [1966], A educação e o milagre brasileiro [1974] e Prioridade para os alicerces da educação [1976]. Louremberg Ribeiro Nunes Rocha nasceu em 1942, advogado e professor, foi deputado federal, 1979-1983, MT, ARENA e senador (Constituinte), 1987-1995, MT, PMDB. Foi Procurador do Estado de São Paulo, 1971-1973; Consultor Jurídico, Secretaria de Educação de São Paulo, 1971-1973; Procurador da Fazenda Nacional; Professor Assistente de Direito Processual Civil, PUC, SP; Auxiliar de ensino de Teoria Geral do Direito, USP; Secretário da Educação e Cultura; Vice-Chanceler, Univ. Estadual, MT, 1975-1978. O pai, Joaquim Nunes Rocha, foi deputado estadual entre 1964 e 1975 e deputado federal por Mato Grosso entre 1975 e 1979. Antônio Jesus Dias nasceu em 1942, radialista, professor, ministro evangélico, psicólogo e líder sindical. Filiou-se à ARENA, 1978-1979; PDS, 1980-1985; PMDB, 1986Foi subchefe do Gabinete Civil da Governadoria do Estado de Goiás, 1979-1980 e diretor da FEBEM, Goiânia, GO, 1980. Manoel Bezerra de Melo nasceu em 1926, professor, psicólogo e orientador educacional, foi deputado federal, 1967-1971, SP, ARENA; deputado federal, 1971-1975, SP, ARENA; deputado federal, 1979-1983, SP, ARENA. Filiou-se à ARENA, 1966-1979; PDS, 1980-1985; PMDB, 1986-. Foi Reitor, Chanceler e Fundador da Universidade de Mogi das Cruzes, SP, 1973; Diretor da Faculdade de Filosofia, Ciências e Letras de Mogi das Cruzes, SP. Diretor da Divisão de Relações Públicas da Secretaria de Educação do Estado de São Paulo, 1963-1964; Fundador, Rede de colégios Capital, Fortaleza, CE. Márcia Kubitschek nasceu 1943, Jornalista, filha do expresidente Juscelino Kubitschek de Oliveira e Sarah Luiza Lemos de Oliveira. Filiou-se ao PMDB, 1982-1989; PRN, 1989-1992. Renunciou ao mandato de Deputada Federal, na Legislatura de 19871991, para assumir o mandato de Vice-Governadora do Distrito Federal, em 01 de janeiro de 1991. Foi jornalista do Jornal do Brasil, Última Hora e da Manchete; Diretora, Fundação Cultural do Rio de Janeiro, RJ, 1974-1977; Chefe do escritório, da Empresa Brasileira de Turismo (Embratur), Nova lorque, 1985-1986; Secretária-adjunta, Secretaria do Ministério da Indústria, Comércio e do Turismo, 1995. Octávio Elísio Alves de Brito nasceu em 1940, engenheiro e professor, filiou-se ao PMDB, 1987-; PSDB, 1988 -. Foi professor de Economia e Legislação Mineral, Instituto de Geociências, UFMG, 1977-; professor de Tratamento de Minério, Esc. de Minas de Ouro Preto; secretário-adjunto de Ciência e Tecnologia do Estado de Minas Gerais, 1977-1979; secretário executivo da FUNDEP, UFMG, 1979-1983 e secretário de educação do Estado de Minas Gerais, 1983-1986. Osvaldo Roberto Sobrinho nasceu em 1949, advogado, economista, professor e empresário, foi deputado estadual, 1979-1983, MT, ARENA e Deputado Estadual, 1983-1987, MT, PMDB. Filiou-se à ARENA, 1976-1979; PP, 1980-1982; PMDB, 1984-1988; PTB, 1988-2000; PSDB, 2000; PTB, 2000-. Foi professor de Geografia, Sociologia e Educação Física, Rede Estadual de Ensino do Mato Grosso, 1969-1978; Monitor de Formação Econômica, UFMT; Coordenador de Estágio e Professor, ETFMT; Professor-Assistente, UFMT, 1973-1974 e Delegado Regional de Educação e Cultura de Cuiabá, MT, 1974-1978. Paulo de Tarso Tavares Silva nasceu em 1957, professor, foi deputado estadual, 19831987, PI, PMDB. Filiou-se ao PMDB, 1983-1988; PSDB, 1988-1993. Atuou como diretor dos jornais Tribuna do Povo e Folha do Piauí. José Tadeu Bento França nasceu em 1946, professor, foi vereador, 1977-1983, Maringá, PR, MDB e deputado estadual, 1983-1987, PR, PMDB. Filiou-se ao MDB, 1976-1979; PMDB, 1980-1988; PDT, 1988-. Atuou como professor da Rede Estadual de Ensino, Paraná. Ubiratan Diniz de Aguiar nasceu em 1941, advogado e professor, foi vereador, 1967-1971, Fortaleza, CE, ARENA; deputado estadual, 1979-1983, CE, ARENA e deputado estadual, 1983-1987, CE, PDS. Renunciou, em 2 de maio de 2001, ao mandato de Deputado Federal na legislatura 1999-2003, para assumir o cargo de Ministro do Tribunal de Contas da União. Filiou-se à ARENA, 1966-1979; PDS, 1980-1984; PMDB, 1986-1994; PSDB, 1994-. Atuou como Oficial de Gabinete do Secretário de Administração do Estado do Ceará; Presidente, Instituto de Previdência Social, Fortaleza, CE; Chefe de Gabinete do Prefeito de Fortaleza, CE; Secretário Municipal de Administração, Fortaleza, CE, 1970-1973; Secretário de Educação do Estado do Ceará, 1983-1985. Foi sócio fundador do Lions Clube. Flávio Palmier da Veiga (1932-2012) foi deputado estadual por seis mandatos e mais três como deputado federal, tendo iniciado sua vida política como vereador, em 1958. [Página retirada]. França Teixeira (1944-2013) [Página retirada]. Átila Freitas Lira nasceu em 1947, economista e administrador de empresas, filiou-se ao MDB, 1973-1974; ARENA, 1976-1979; PDS, 1980-1984; PFL, 1986-1999; PSDB, 1999-2007; PSB, 2007-. Foi Secretário de Educação do Estado do Piauí, 1983. Cláudio Ávila da Silva nasceu em 1953, administrador de empresas, foi prefeito, 1983-1985, Florianópolis, SC, PDS e Deputado Estadual, 1985-1987, SC, PDS. Filiou-se à ARENA; PFL; PDS. José Tavares de Moura Neto nasceu em 1941, advogado, bancário e 
comerciante, foi deputado federal, 1983-1987, PE, PDS. Filiou-se ao PDS, 1983-1985 e PFL, 1985-. Foi Presidente do Sport Club do Recife, 1979-1980. Presidente do Conselho Deliberativo do Sport Club do Recife, 1981- 1982. José Queiroz da Costa nasceu em 1936, empresário, bancário, comerciante e representante comercial, filiou-se ao PSD; PFL; PDS e ARENA. Agripino de Oliveira Lima Filho nasceu em 1931, advogado e professor, foi vereador, 1973-1977, Presidente Prudente, SP, ARENA e vereador, 1977-1983, Presidente Prudente, SP, ARENA. Filiou-se à ARENA, 19711979; PDS, 1980-1981; PTB, 1981-1984; PFL, 1985-. Atuou como Professor I, Graça, SP, 1952-1958. Reitor, Universidade de Presidente Prudente; Diretor de Escola, 1958 e Professor III, 1972-1974, Presidente Prudente, Secretaria de Educação e Cultura de São Paulo. Dionísio João Hage nasceu em 1935, advogado e professor, foi deputado federal, 1983-1987, PA, PMDB. Filiou-se ao PMDB, 1981-1984; PFL, 1985-; PRN, 1989-. Atuou como Subsecretário de Educação do Estado do Pará 1975 e 1979-1982; Presidente e Assessor Jurídico da Fundação Educacional do estado do Pará, PA, 1979-1982. Publicou História do Pará (1962); Pontos da Nossa História. (1970); Estudos Sociais e Educação Moral e Cívica. (1973); Símbolos do Estado do Pará: datas e fatos de nossa história. (1973); entre outros. Foi diretor do Instituto de Educação do Pará, Belém, 1968-1975. Membro do Conselho Estadual de Educação, Pará, 1979-1982. Membro do Diretório Regional do PMDB, Pará, 1981-1984. Representante da Câmara no Círio de Nossa Senhora de Nazaré, Belém, 1983. Representante da Câmara no I Encontro Científico e Tecnológico dos Países do Tratado de Cooperação Amazônica, 1984. Fundador do Partido da Frente Liberal, Pará. Membro da Comissão Diretora Regional Provisória do PFL no Pará. Vice-Presidente do PFL no Pará. Membro Efetivo do Diretório Nacional do PFL. Presidente do Conselho da Campanha Nacional de Escolas da Comunidade. Fundador dos Sindicatos dos Professores e dos Advogados do Pará. Francisco Humberto de Freitas Azevedo nasceu em 1946, médico e produtor rural, foi um dos fundadores do PDT no Triângulo Mineiro. Atuou como diretor da UESU - União dos Estudantes Secundáristas de Uberlândia, 1963-1964; Membro Fundador e Primeiro-Vice-Presidente do Dadu - Diretório Acadêmico Domingos Pimentel de Uchoa, da Faculdade de Medicina Universidade Federal de Uberlândia, 1968-1969. Sólon Borges dos Reis nasceu em 1917, advogado, jornalista e professor, foi deputado estadual, 1959-1963, SP, PDC; deputado estadual, 1963-1967, SP, PDC; deputado estadual, 1967-1971, SP, ARENA; deputado estadual, 1971-1975, SP, ARENA; Deputado Estadual, 1975-1979, SP, ARENA; deputado federal, 4/11/1985-4/3/1986, SP, PTB. Renunciou ao mandato de Deputado Federal na legislatura 1991-1995 para assumir o cargo de Vice-Prefeito de São Paulo, em $1^{\circ}$ de janeiro de 1993. Filiou-se ao PTB; ao PDC, 1959-1965 e à ARENA, 1966-1979. Atuou como Assistente Geral do Ensino, 1948-1950; Chefe de Ensino Secundário e Normal, SP, 1954; Professor e Diretor de escola no Ensino Público e Particular de Primeiro, Segundo e Terceiro Graus; Cronista Parlamentar, Diários Associados na Constituinte, 1947, e Assembleia Legislativa, SP, 1948; DiretorGeral, Departamento de Educação, SP, 1955-1957; Secretário de Educação do Estado de São Paulo, 1962; Vice-Presidente da Confederação dos Educadores Americanos, Uruguai, 1957. Fundador, 1947 e Presidente da União Paulista de Educação; Fundador da Apeoesp e Presidente do Centro do Professorado Paulista. Publicou Apostasia (1937); Imprensa e Educação (1940); Algumas considerações sobre programas escolares (1941); Novas poesias escolares (1948); Geografia e História do Brasil (1948); Poesias escolares (1956); A maior herança (1965); Lira da América (1973). A crise contemporânea da educação (1978); Abc da Constituinte (1985); Condição humana (1987); Educação Política (1988); Carrossel do tempo (1988); Educação política, educação para a liberdade e para a responsabilidade (1990) e Poesias infantis (1990). Florestan Fernandes nasceu em 1920, professor e sociólogo, filiado ao Partido dos Trabalhadores (PT). Foi Professor, Univ. de Colúmbia, EUA, 1965, Yale, EUA, 1965-1977, e Toronto, Canadá, 1969-1972; Colaborador, O Estado de S. Paulo, Folha de São Paulo, Folha da Manhã e outros jornais e revistas; Professor da Graduação, 1977, e da Pós-Graduação, 1978 a 1985, PUC, São Paulo, SP; Segundo Assistente da Cadeira de Sociologia II, 1945, e Primeiro Assistente da Cadeira de Sociologia I, 1952-1954, Fac. de Filosofia, Ciências e Letras, Univ. de São Paulo; Professor Contratado, Cadeira de Sociologia I, 1955-1965, e Professor Catedrático, Concursado, da Universidade de São Paulo, 1965-1969. Publicou Karl Marx, Contribuição à Crítica da Economia Política (1946); A Etnologia e a Sociologia no Brasil: Ensaio sobre Aspectos da formação e desenvolvimento das Ciências no Brasil (1958); A Organização Social dos Tupinambás (1949); Educação e sociedade no Brasil (1966); The Latin America ins residence lectures (1969-1970); A função social da guerra na sociedade Tupinambá (1964); Negros e Brancos em São Paulo (Coautoria) (1951); 2.ed. 1971; O negro no mundo dos brancos (1972); Las clases sociales en America Latina. (Em colaboração com Alain Touraine) (1973); Comunidade e sociedade. Leituras sobre problemas conceituais, metodológicos e de aplicação (Org.) (1973); Elementos de sociologia teórica (1973); Comunidade e sociedade no Brasil. Leituras básicas de introdução ao estudo macro- 
O Brasil que chegava ao processo constituinte era um país no qual havia 30 milhões e 401 mil analfabetos, ou 25\% da população; $87 \%$ das crianças frequentavam a escola, recebendo um ensino de primeiro grau bastante precário, deixando sete milhões de crianças sem escola. Embora com seus índices econômicos em crescimento, o Brasil era um país que gastava 3,3\% de seu PIB com a educação.

O deputado federal Florestan Fernandes, eleito pelo PT de São Paulo, criticava o fato do tema da educação ter sido relegado a uma Subcomissão que deveria tratar de uma variedade de questões econômicas e sociais, reduzindo a educação a uma concepção substancialista, "um assunto secundário. Ela faz parte de um armário de despejo. Todos os assuntos podem ser lá jogados, podem lá ser tratados e, possivelmente, sem seriedade" (Fernandes apud Soares, 1999, p.127).

sociológico do Brasil (Org.) (1975); A investigação etnológica no Brasil e outros ensaios (1975); Ensaio de sociologia geral e aplicada (1976); A sociologia numa era de revolução social (1976); As classes sociais na América Latina (Coautoria) (1977); Circuito Fechado: quatro ensaios sobre o poder institucional (1977); A condição de sociólogo (1978); A integração do negro na sociedade de classe (1978); O folclore em questão. São Paulo (1978); Lenin (1978); Folclore e mudança social na cidade de São Paulo (1979); Da guerrilha ao socialismo: a Revolução Cubana (1979); Apontamentos sobre a teoria do autoritarismo (1979); A universidade brasileira: reforma ou revolução? (1979); Mudanças sociais no Brasil (1979); Fundamentos empíricos da explicação sociológica (1980); A sociologia no Brasil. Contribuição para o estudo de sua formação e desenvolvimento (1980); Brasil: em compasso de espera (1980); A Natureza sociológica da sociologia (1980); Movimento socialista e partidos políticos (1980); Sociedade de classes e subdesenvolvimento (1981); Poder e contra-poder na América Latina (1981); O que é revolução? (1981); A revolução Burguesa no Brasil. Ensaio de interpretação sociológica (1981); Capitalismo dependente e classes sociais na América Latina (1981); A ditadura em questão (1982); K. Marx - F. Engels: História (1983); A questão da USP (1984); Que tipo de república? (1986); Nova república? (1986); O desafio educacional (1989); Significado do protesto negro (1989); Constituição inacabada (1989); Pensamento e ação: o PT e os rumos do socialismo (1989); A transição prolongada (1990). Atuou no Movimento Estudantil, ocupando o Cargo de Diretor do Departamento de Ciências Sociais, do final de 1942 até a queda da Ditadura. Membro da Quarta Internacional, 1942-1951. Álvaro Bastos do Valle nasceu em 1934, professor, diplomata e bacharel em direito, foi deputado estadual, 1962-1964, GB, UDN; deputado estadual, 1971-1975, GB, ARENA; deputado federal, 1975-1979, RJ, ARENA; deputado federal, 1979-1982, RJ, ARENA; Deputado Federal, 1983-1987, RJ, PDS. Filiou-se à UDN, 1962-1964; ARENA, 1971-1980; PDS, 1980-1985; PL, 1985-. Atuou como professor e advogado, Rio de Janeiro, RJ; Carreira Diplomática: Terceiro-Secretário, 1958, Segundo-Secretário, 1961, Primeiro-Secretário, 1970, Conselheiro, 1978, Ministro, 1983, e Embaixador, 1994, MRE. Publicou Conselheiro Saraiva; O presidente e a revolução (1960). Turismo: um estudo do mercado norte-americano (1965); Suécia e outros assuntos (1968). Os contemporâneos: romance (1969); Estruturas políticas brasileiras (1970). Los contemporáneos. (1970). Comunicação e expressão: composição e interpretação (1973); As novas estruturas políticas brasileiras (1977); Carta para um jovem cristão (1978); As eleições de 1982 e o voto distrital (1984); O Parlamento: contribuição para um estudo comparativo de regimentos parlamentares (1984). $O$ bom combate (1985); O liberalismo social e o programa do Partido Liberal (1987) e O liberalismo social (1996). Nota organizada a partir das informações biográficas dos parlamentares disponíveis em: http://www2.camara.leg.br/atividade-legislativa/legislacao/Constituicoes Brasileiras/constituicaocidada/constituintes/parlamentaresconstituintes/biografia-dos-parlamentares-constituintes Acesso em: 12 mai. 2015. 
Sem tergiversar a articulação entre interesses econômicos e a busca pela democratização política e social, nesse cenário a educação - como em contextos históricos das constituintes de 1934, 1946 e 1964 - ganhou foco como possibilidade de inserção social. As discussões em torno do tema ganharam condições para colocar em pauta experiências liberalizantes concentradas no Fórum Nacional da Educação na Constituinte em Defesa do Ensino Público e Gratuito. A política educacional daquela conjuntura trazia a disputa pela escola pública, remontando a um longo processo iniciado nos anos de 1920, quando começaram a ser confrontadas tendências ligadas ao setor privatista. Naquele momento, o debate se dividia entre os chamados católicos e os ditos liberais, nomenclatura bastante discutível, já que de ambos os lados havia católicos e liberais. Mesmo assim, com o setor católico identificaram-se as forças mais atrasadas, que defendiam o direito a financiamento público para escolas confessionais. Para os liberais, que estiveram presentes, representados pela Associação Brasileira de Educação (ABE), no Manifesto dos Pioneiros da Educação Nova (1932) e na Constituinte de 1934, a verba da educação deveria ser exclusivamente destinada a instituições públicas. Ao ter do lado progressista de seu espectro a Associação Brasileira de Educação (ABE) e, de outro, o setor conservador, da Liga Eleitoral Católica (LEC), a Constituição de 1934 foi reconhecida, em alguns de seus dispositivos, como a Carta mais avançada até a de 1988.

Na Constituição de 1934, a educação tornou-se:

[...] direito declarado. E, excetuados os casos em que a força se sobrepôs à lei e o arbítrio ao direito (ainda que textualmente mantido em vários itens, como no caso da educação escolar primária), as constituições posteriores não fizeram mais do que manter, ampliar ou recriar esse direito declarado (Fávero, 2005, p. 25).

Porém, nem na Constituição de 1934, nem nas que Ihe seguiram, a educação foi reconhecida como direito público subjetivo, intrínseco a todos e a cada cidadão ${ }^{14}$. Apenas cinquenta e quatro anos depois, a ideia de direito público subjetivo foi

\footnotetext{
14 "Na realidade, constitui um dos fundamentos do Estado de Direito Social a possibilidade de participação de todos nos bens da coletividade e uma melhor distribuição desses bens. Se essa participação for negada, pois o Poder Público não organiza sistemas adequados para atender à demanda dos grupos mais despidos de poder, por exemplo, deve-se buscar proteção jurídica para corrigir esta situação indesejada. A figura do direito público subjetivo, quando utilizada para proteger um bem que é ao mesmo tempo individual e social, deve se prestar à exigibilidade do caráter coletivo de tais direitos, ou seja, à exigibilidade de políticas públicas." (Duarte, 2004, p. 116)
} 
consagrada, tornando-se a marca que singulariza a Constituição de 1988 em matéria de educação. É possível apontar alguns aspectos, responsáveis pelo referido direito legítimo ter se tornado legal:

A ambigüidade entre instituições responsáveis pela
obrigatoriedade talvez explique por que se levou tanto tempo
para que a educação fosse reconhecida como direito público
subjetivo. Como se sabe tal direito diz do poder de ação que a
pessoa possui de proteger ou defender um bem considerado
inalienável e ao mesmo tempo legalmente reconhecido. Daí
decorre a faculdade, por parte da pessoa, de exigir a defesa ou
proteção do mesmo direito da parte do sujeito responsável. Se
havia normas do Código Penal para assegurar essa proteção
incriminando a família, o mesmo não existia, até 1988, em
relação ao Estado, a fim de possibilitar ao indivíduo o uso de
mecanismos jurídicos correspondentes ao direito declarado. Mas
ao mesmo tempo o direito subjetivo tem sua face pública, na
medida em que expressa o reconhecimento de um direito que
tem a ver com o interesse coletivo, e isso de tal modo que nele
esteja implicado o próprio interesse do Estado. (Ibidem, p. 25-6).

Apenas desde 1988 o Estado pode ser juridicamente acionado e criminalizado por não atender àquilo que dispõe a sua Carta Magna em vários campos e, em particular, no que se refere à educação, prevendo a figura do mandado de injunção para monitorar os excessos que venham a ser cometidos pelo poder estatal. Este direito foi conquistado à custa de tensões, debate e negociação para tornar possível formular e efetivar políticas adequadas àquela etapa dos conflitos sociais, alterando o modelo de sociedade e criando as condições legais para as políticas, em particular, a educacional.

\section{2 - Uma Constituição "Enxuta” ou "Encharcada”?}

Na nona reunião ordinária da Subcomissão de Educação da Constituinte, em 21 de abril de 1987, Álvaro Valle (PL-RJ), ao realizar a primeira contribuição de mérito ao debate - como também o presidente Hermes Zaneti (PMDB-RS), destacou duas das propostas apresentadas, à Mesa da Assembleia Nacional Constituinte, a serem debatidas na Subcomissão: a primeira, em relação à aposentadoria dos professores - vinte e cinco anos de serviço para professoras e trinta anos para professores - e a segunda, em relação à extensão da educação obrigatória dos 
cinco aos 14 anos, ao invés de 7 a 14 anos, o que significava integrar a pré-escola como obrigatória. Ao fazê-lo, referia-se ao tipo de Constituição que deveria resultar do processo constituinte:

Não creio que devamos fazer uma Constituição extremamente longa,
ao contrário, sou dos que defendem uma Constituição sintética, por
isso certas matérias, sobretudo referentes a pessoal, não creio, em
tese, que deveriam constar da futura Constituição brasileira. Mas,
Senhor Presidente, acredito que algumas exceções devam ser
abertas, sobretudo, devemos manter na futura Constituição aquelas
conquistas que já foram asseguradas por Constituições anteriores.
Não faria sentido a Nova República promulgar uma nova
Constituição. (ANC, 1988b, p. 12).

Era o início do debate sobre a natureza da Constituição que resultaria do processo Constituinte. Ubiratan Aguiar (PMDB-CE) abordou a questão, reforçando a ideia de uma Constituição enxuta, não deixando de indicar a relevância de assegurar maiores garantias de concretização de algumas das determinações constitucionais. Convém transcrever as ideias formuladas por Aguiar:

[...] o outro ponto [...] que nos preocupa, porque sabemos que, por mais sintética que seja a Constituição, a norma geral traça apenas o lineamento geral - e assim entendo deva ser - ficam várias normas dependendo de uma legislação ordinária, de uma legislação complementar. A sugestão nossa é no sentido de que, já que aqui há um fórum de educadores e de Constituintes educadores, pensássemos que aquelas medidas que dependessem de lei complementar, de legislação ordinária, ao término dos nossos trabalhos, já pudessem elencar todas elas, para dar uma contribuição desta Subcomissão da Educação, Cultura e Esportes, no sentido de que não houvesse aquele tão danoso à vista das instituições, qual seja ficasse a depender de iniciativa de apresentação de leis que regulamentassem dispositivos constitucionais [...] (ANC, 1988b, p.14)

A questão do alcance e da efetividade reapareceria nas considerações do constituinte Florestan Fernandes (PT-SP) como intrinsecamente ligada ao critério do que seria ou não constitucional, acentuando que uma concepção dinâmica e histórica seria um guia para a construção de políticas sociais, em particular populares, daí a necessidade de ser mais detalhada e, por isso, mais alargada. Apontava sua preocupação com o tamanho da Constituição, indicando a necessidade - sobretudo no caso da educação - de inovar, aumentando o número de normas constitucionais e se afastando de formulações gerais e abstratas delineando a construção de uma democracia com reconhecimento das diferenças, 
em oposição ao autoritarismo que, ao contrário, diluía as diferenças. Por fim, enfatizava como problema central o quanto o Estado deveria investir na educação. Ora, ao envolver o critério do que poderia ser considerado constitucional ou inconstitucional, revelava-se a mudança na concepção do que significava política no Brasil. Cito Florestan Fernandes:

O critério do que é constitucional e do que não é constitucional é um critério que varia no tempo. Se um país resolveu, por meios não constitucionais, por meio de tradição, seus problemas capitais, ele prescinde de uma Constituição abundante. Se esse país não logrou, como é o caso do Brasil, necessariamente ele precisa de uma Constituição que não seja tão enxuta e que realmente imponha certas obrigações, às vezes até recorrendo a penalidades [...]. Portanto, aproveitando a deixa que o próprio constituinte Álvaro Valle levantou, contradizendo, em termos, a defesa de uma Constituição enxuta, acho que a nossa Constituição deve ser molhada e salgada. (ANC, 1988b, p. 15)

Esse debate demonstra, de forma abrangente, a tensão em torno do papel da Constituinte e da Constituição, no que se refere à garantia de determinações que permitissem a realização de tarefas sociais e democráticas ainda não alcançadas, e ao corpo de decisões que pudessem concorrer para a mudança dos padrões educacionais no país. As manifestações revelam perspectivas plurais, embora os principais interlocutores - os professores - não estivessem diretamente presentes. A manifestação em defesa de um texto constitucional enxuto, exceto no que se referia à aposentadoria dos professores, permite supor que houve uma negociação de interesses em torno de diversas concepções.

Havia chegado a hora de reconhecer que as mudanças dependiam de um processo de negociação - que embora apresentasse continuidade em uma série de dimensões importantes, fazia-se incluindo os egressos do regime militar - marcado pela competição das propostas de diferentes sujeitos sociais, mas sem deixar de apontar para a sustentação e legitimação do trabalho da Subcomissão, da ação dos parlamentares, de seus respectivos partidos e do próprio processo constituinte. $O$ espaço e a possibilidade das concessões foram admitidos no contexto do confronto de opiniões e de programas em torno da construção social de significados, construídos no âmbito dos vários aspectos e dimensões do jogo político. Este parece ser o sentido das considerações de Sólon Borges dos Reis (PTB-SP) que, ao fazer referência à manifestação de Ubiratan Aguiar (PMDB-CE) sobre a elaboração 
de leis complementares voltadas à especificação das normas constitucionais, observou a necessidade de modificar a forma dos dispositivos constitucionais de criar vínculos eficazes e efetivos com as lutas sociais. Nessa ocasião, Sólon Borges dos Reis também enfatizou o caráter unitário da educação, sem descurar da heterogeneidade característica da nação brasileira:

O constituinte Florestan defende uma Constituição que seja
aplicada, seja ela enxuta ou encharcada, porque o que se tem
em mira não é fazer um ordenamento apenas jurídico e formal,
mas resolver os problemas que angustiam a Nação, e é óbvio
que todos nós aqui subscrevemos a tese de que só a educação
pode levar o País a um grande estilo e fazer do Brasil uma
grande Nação. Agora, também, se poderia fazer uma lei
orgânica da educação, que não fosse uma lei de diretrizes e
bases como nós temos, porque, ao invés de se limitar as bases
sobre as quais se assentam o ensino no Brasil e as diretrizes
pelas quais se norteia, se impõe uma camisa-de-força que
vigora ao mesmo tempo em todo País. [...] Realmente não é o
que se deve entender por uma lei orgânica dos municípios, uma
lei de diretrizes e bases, porque se deve manter unidade
nacional e isso é prioritário. Mas não se deve promover a
uniformidade nacional, mesmo porque é inexequível, violenta a
realidade diversificada do Brasil. (ANC, 1988b, p.17)

Pelo lugar que ocupa no discurso, merece destacar a ênfase atribuída à educação para fazer do Brasil uma grande-nação em lugar do Brasil grandepotência $^{15}$ o que, aliás, era uma ideia consensual, embora fossem distintos os entendimentos acerca do significado de nação. Este papel instrumental unificava os constituintes quanto à prioridade dada à educação, minimizando as diferenças no que se referia à natureza da Constituição e à melhor forma de concretizá-la, desde que firmado o compromisso com a elaboração de uma legislação complementar.

De maneira sutil e indireta, Sólon Borges introduziu no plenário constituinte outra questão fundamental, relativa às responsabilidades dos entes federados em

\footnotetext{
${ }^{15}$ Com o Golpe de Estado de 1964, os planos educacionais estiveram a serviço da construção do Brasil grande-potência, isto é, uma grande nação capitalista que pudesse ter lugar destacado na disputa e competição internacionais, projeto para o qual deveria se buscar a participação intensa das elites e a integração do povo. Desta forma, a educação ganhou um papel fortemente instrumental, devendo a um só tempo permitir a formação de quadros necessários ao desenvolvimento industrial crescente e assegurar a adesão ideológica ao projeto nacional dos militares, norteado pela perspectiva da segurança nacional. A educação deveria estar a serviço dos objetivos estratégicos do Brasil e de sua aliança com os Estados Unidos da América (EUA). Contudo, esta perspectiva não significava ampliar a oferta em todos os níveis da educação pública. Ao contrário, a privatização do ensino superior durante os governos militares foi significativa, até porque os investimentos do Estado foram direcionados para áreas consideradas estratégicas: o desenvolvimento econômico e a segurança nacional.
} 
relação à oferta da educação pública. Ao reconhecer a necessária unidade nacional, salientava que as Leis Orgânicas Municipais deveriam se ocupar da regulamentação da Constituição em nome da negação de "uma camisa de força nacional" e da necessidade de respeitar a pluralidade sociocultural dos municípios brasileiros. Significava colocar no debate - para além da natureza das leis - as competências dos entes federados, além de apontar a natureza de suas responsabilidades e dos demais níveis de governo, como matéria de natureza constitucional.

Estava em pauta um debate recorrente na história das constituições brasileiras, qual seja o tema da responsabilidade da União no que se refere aos diversos níveis da educação, em função de uma prerrogativa de ordenamento e planejamento nacional, em particular quanto à responsabilidade da União (de maneira supletiva ou direta) em relação aos diversos níveis da educação, seja em função de sua prerrogativa de ordenamento e planejamento nacional - e, portanto, institucional - seja em função da capacidade de financiamento. Como se sabe esse debate não era inédito na história das constituições brasileiras, tendo marcado a própria formação da República Federativa Brasileira.

\section{3 - Educação e Imaginário Nacional}

Desde o início dos trabalhos da Constituinte, as várias representações da nação implicavam a retomada e a ressignificação de noções - em particular de nacionalismo - cujas formas e funções eram conformadas em diferentes espaços e temporalidades. A leitura de Eric Hobsbawm traz a possibilidade de entendermos o nacionalismo no passado e na atualidade. Abrindo essa discussão, em Nacionalismo e Marxismo (1980), chamou a atenção para o fato de que:

O ponto crucial do nacionalismo moderno, em termos políticos, é a exigência de 'autodeterminação', isto é, a de constituir algo como um 'estado-nação', tal como esse termo vem sendo entendido hoje em dia: uma unidade territorial soberana e idealmente homogênea, cujos habitantes, membros de uma 'nação', definida por uma variedade de critérios convencionais (étnicos, linguísticos, culturais, históricos, etc.) seriam os 'cidadãos'. (Hobsbawm, 1980, p. 294)

Nações e nacionalismo desde 1780 (2011) é uma obra paradigmática. Depois de considerar que o maior número de trabalhos sobre o tema se concentrou entre os 
anos de 1968-1988, ele assinalou uma breve análise de uma lista concisa de autores, mas esta definição, segundo o autor, não é suficiente para dar conta de um fenômeno histórico localmente enraizado e mutável. Ao retomar e reiterar Ernst Guellner, ele salienta que o nacionalismo é "fundamentalmente um princípio que sustenta que a unidade política e social deve ser congruente" (Gellner apud Hobsbawm, 2011, p. 18). Nesta chave de análise, ele considera que o "dever político" ao Estado - ou Estado-Nação - supera "todas as outras obrigações de qualquer tipo". (Hobsbawm, 2011, p.18-9)

Adiante, Hobsbawm ressalta, com Guellner:

[...] eu enfatizaria o elemento do artefato, da invenção e da engenharia social que entram na formação das nações. [...] Em uma palavra, para os propósitos da análise, o nacionalismo vem antes das nações. As nações não formam os Estados e os nacionalismos, mas sim o oposto. (Ibidem, p.19)

Por fim, ele assinala um aspecto fundamental:

[...] as nações são, do meu ponto de vista, fenômenos duais, construídos essencialmente pelo alto, mas que, no entanto, não podem ser compreendidas sem ser analisadas de baixo, ou seja, em termos das suposições, esperanças, necessidades, aspirações e interesses das pessoas comuns, as quais não são necessariamente nacionais e menos ainda nacionalistas. (Ibidem, p.19-20)

Neste sentido, o nacionalismo não comporta o "eles", porque não faz parte da imaginação nacional a existência de exclusão. Em outro registro analítico, Benedict Anderson apresenta alguns argumentos convergentes com os de Hobsbawm, como a asserção de que o nacionalismo é plural e pode ser definido como “'cruzamento' complexo de diferentes forças históricas" que "depois de criados esses produtos se tornaram modulares". Cito:

O meu ponto de partida é que tanto a nacionalidade - ou, como talvez se prefira dizer, devido aos múltiplos significados desse termo, a condição nacional [nation-ness] - quanto o nacionalismo são produtos culturais específicos. Para entendê-los temos de considerar, com cuidado, suas origens históricas, de que maneiras seus significados se transformaram ao longo do tempo, e por que dispõem, nos dias de hoje, de uma legitimidade emocional tão profunda. (Anderson, 2008, p. 30) 
Tanto para Hobsbawm como para Anderson, cujas elaborações analíticas estavam carregadas de nítidos traços das experiências históricas europeias, a educação foi definida como domínio de uma língua comum, cuja precípua responsabilidade do ensino cabia à escolaridade formal. Este processo seguiu o caminho da formação dos Estados nacionais europeus. Hobsbawm chamou a atenção para o fato de que os Estados nacionais foram se formando concomitantemente à organização dos sistemas educacionais

[...] que se constituíram em um dos principais fatores de integração política e de configuração da chamada identidade nacional, de coesão social, de transmissão dos valores das classes dirigentes e de seleção e legitimação das elites dominantes. (Hobsbawm apud Filmus, 1999, p. 15)

No Brasil, a educação foi concebida, sobretudo nos anos de 1920, como necessidade da República, porquanto capaz de regenerar e aperfeiçoar o povo, fortalecendo o caráter nacional brasileiro para a construção de uma grande nação. Afinal, não seria possível definir um Estado nacional sem colocar-se frente aos problemas nacionais, em particular, a educação, cujo papel foi hiperdimensionado: tratava-se de dar forma ao país amorfo, de transformar os habitantes conforme os anseios de Ordem e Progresso, definidos e levados a cabo por elites formadas pelos mais capazes, os mais aptos, com autoridade para promovê-los.

Entretanto, não é demais ressaltar que o direito à educação foi, na maioria das vezes, indistinguível das necessidades do próprio capitalismo de tal sorte, que sua garantia passou a ter um claro sentido instrumental e - ainda que com prevalências e intensidades distintas - voltou-se para necessidades de mercado de trabalho e aos anseios de ascensão social. Também por isso, a educação foi quase sempre um projeto familial de uma nação tida como homogênea, sem contradições nem conflitos. No Brasil, ao equalizar Estado e Nação foi atribuído um papel civilizatório à educação, conformando o povo como força homogênea e propulsora da nação. Reiterada na década de 1950, a ideologia desenvolvimentista nacionalista continha uma clara intenção, a de que a educação enquanto direito do cidadão deveria ser propulsora da construção da identidade nacional própria de um país voltado para o desenvolvimento do capitalismo.

Não obstante as contradições apresentadas naquela década no que diz respeito à análise da realidade brasileira, assim como na prática política, o 
nacionalismo desenvolvimentista deixou seu legado para as décadas subsequentes. E dada a conhecida abrangência e ambiguidade oferecidas pela própria História, o nacionalismo se desdobrou, em especial, em duas vertentes: a autoritária, cuja ação política tinha por objetivo o controle das classes populares, e a democrático-popular, identificada com a luta sistemática em favor dos movimentos sociais, no sentido de contestar e, sobretudo, de romper o autoritarismo na vida política brasileira.

Cabe recorrer uma vez mais à História para assinalar que, em março de 1964, instaurado o regime militar autoritário que põe fim ao entreato da democracia burguesa em nosso país, o nacionalismo foi utilizado para justificar a violência e a repressão, ou seja, as aposentadorias compulsórias de intelectuais das universidades e centros de pesquisa, o exílio, as prisões, as torturas, as mortes e os desaparecimentos, práticas realizadas em nome de uma política saneadora revestida de um grande amor à Pátria. "Brasil: ame-o ou deixe-o" foi a triste bandeira nacionalista dos anos 1970, em nome da repressão aos movimentos de resistência, obstáculos para a construção de um Brasil como grande potência econômica capitalista, moralmente afinada com os necessários expurgos dos que tentavam colocar em risco as premissas da civilização cristã.

Significa dizer que, até 1964, o nacionalismo fez parte de um processo ideológico de construção em que sonhos, reivindicações, frustrações, indignações e mudanças eram imputados ao povo e à nação, ainda que as representações tenham ficado em mãos das vanguardas formadas por artistas e intelectuais. Este nacionalismo pressupunha uma nação capaz de fazer as reformas necessárias nas várias dimensões da vida do país, o que significava pôr em curso a reforma agrária, romper o jogo de classes que mantinha uma cada vez mais abusiva concentração de rendas, e provocar rupturas na presença maciça do capital estrangeiro representado pelo Fundo Monetário Internacional (FMI), pela Aliança para o Progresso (AP), o Instituto Brasileiro de Ação Democrática (IBAD), o Instituto de Pesquisa e Estudos Sociais (IPES) e a Agência dos Estados Unidos para o Desenvolvimento (USAID).

Por sua vez, desde o golpe de 1964, passou a ser crescentemente ressaltada a importância do desenvolvimento e da defesa da soberania do Estado Nacional como elementos necessários para a formação da identidade da nação. Como em diversas outras conjunturas no Brasil, uma vez mais a categoria de nação se tornava 
fundamental, desta feita ancorada em forte grau de emocionalismo. Em oposição, o pensamento militar elaborado e difundido pela Escola Superior de Guerra e pelas Forças Armadas naturalizou o papel das elites enquanto intérpretes da vontade nacional, elas teriam melhor qualidade de formação e informação, razão pela qual, além de melhores condições de percepção dos interesses e aspirações nacionais coincidentes com os "Objetivos Nacionais" teriam melhores condições de infundir e difundir junto ao povo - caracterizado pela insuficiência de atributos positivos - os "valores da consciência nacional". (Rocha, 1996)

Como a nação era uma construção do Estado militar autoritário a favor dos interesses de setores "tradicionais" das classes médias - mobilizados pela Igreja e por partidos políticos - e dos chamados "setores agro-latifundistas", os "objetivos nacionais" de segurança e desenvolvimento, por um processo de inversão ideológica, equalizavam povo e elite. Este era um nítido processo de inversão ideológica que conformava uma estrutura discursiva que subtraía o poder como emanando do povo em função da insuficiência de seus atributos, excluindo-o do papel de construtor da nacionalidade. E, ao homogeneizar elite e povo, unificava-se capital e trabalho, elites capitalistas e trabalhadores, encobrindo-se diferenças de classe. Este discurso tinha como centro de sua legitimidade, em um forte grau de emocionalismo inerente à noção de nação brasileira, uma nação amada, em que os poucos que não lhe dedicassem este sentimento deveriam deixá-la.

Pela sua natureza modular e sua apropriação em vários graus de oficialidade e de autoconsciência, o nacionalismo - assim como a Nação -, mesmo submetida a um forte controle do Estado, passou a ser constituído pela pluralidade dos atores e pela heterogeneidade de suas intenções e objetivos políticos. Neste sentido, a nação democrática em processo de construção teria como um dos seus objetivos centrais construir uma democracia com o reconhecimento das diferenças e uma cidadania emoldurada por uma especial atenção à dimensão republicana, cívica, da democracia, colocando no centro a diferença entre o público e o privado.

Existiram outras perspectivas, cujo clichê ingênuo mostrava a faceta de um nacionalismo operante junto a amplos setores da sociedade. É o caso do manifesto "Em Defesa da Nação Ameaçada", de 20 de dezembro de 1980, subscrito por 32 políticos, empresários, intelectuais e dois militares, Antônio Carlos de Andrade Serpa e Carlos Euler Bentes Monteiro, aliás, punidos por se engajarem publicamente na 
luta pelo restabelecimento das liberdades democráticas. Dizia o parágrafo final do Manifesto:

Desta forma, sem outra conotação ideológica além do tradicional patriotismo brasileiro, convocamos homens e mulheres deste país, acima de posições partidárias, sob a proteção de Deus, ao esforço conjunto na defesa dos direitos da nacionalidade. (Lima et al., 1980)

Acima de tudo, o nacionalismo chegava às ruas em manifestações pelo restabelecimento das eleições diretas no Brasil. A nação vestiu verde-amarelo, colorindo o agitado verão de 1984.

Nessa nova conjuntura histórica, a nação e a educação foram enlaçadas como uma das condições da soberania do país em termos culturais - amplo senso e como direito inalienável de todos os cidadãos, o que acolhia os trabalhadores e os setores excluídos. Colocava-se, desta forma, a educação como impulsionadora de um projeto nacional. Contudo, essa concepção encontraria fortes obstáculos para ganhar um detalhamento na Constituição de 1988, em meio à disputa pelo controle dos fundos públicos e à transferência de responsabilidades federais aos demais entes federados, em particular, aos municípios.

Vale lembrar que o direito à educação, não raro, foi indistinguível das necessidades do próprio capitalismo, de tal sorte que garanti-lo passou a ter um claro sentido instrumental e, ainda que com prevalências e intensidades distintas, se voltasse para necessidades do mercado de trabalho e aos anseios de ascensão social dos indivíduos. Neste sentido, a educação foi quase sempre um projeto familial em uma nação definida como homogênea, sem conflito e sem contradições. Esta concepção depositava na educação o papel de impulsionadora de um projeto nacional que, segundo deputados como Sólon Borges dos Reis, não poderia ser objeto de detalhamento na Constituição, para que fosse assegurado o controle dos fundos públicos e a transferência de responsabilidades federais aos demais entes federados, sobretudo, para os municípios. 


\section{4 - Uma Constituição analítica: como o homem constrói o homem}

$\mathrm{Na}$ vigésima quarta reunião da Subcomissão realizada em 12 de maio de 1987, com a presença do então Ministro da Cultura Celso Furtado, o deputado Florestan Fernandes retomou o tema relativo à natureza da Constituição e da nação em conflito ${ }^{16}$ e perguntava:

O que nós devemos construir aqui, uma Constituição sintética ou uma Constituição analítica? Os conservadores estão se batendo por uma Constituição sintética, é uma maneira de ganhar a batalha sem travar o combate. E por isso nós devemos insistir nesse ponto, ele é fundamental. Esta é a primeira oportunidade histórica que o Brasil tem de construir uma Constituição em condições nas quais todas as nações que coexistem no Brasil estão interagindo entre si, todas as classes estão interagindo, e o Parlamento está respondendo às pressões externas e internacionalizando essas pressões [...]. Por isso dou muita importância à resposta que o Ministro Celso Furtado der a esta questão. (ANC, 1988b, p. 423)

O então Ministro Celso Furtado assim se manifestou:

Sobre a natureza da Constituição, diria que este é o problema maior. Evidente que as Constituições modernas tenderam a ser mais analíticas. A ilusão de uma Constituição sintética, à maneira americana, resulta de não entenderem o que é a Constituição nos Estados Unidos, que na verdade está sendo feita permanentemente dentro da tradição do Direito americano e pela própria Justiça, pela Suprema Corte dos Estados Unidos. É como se o país vivesse em processo permanente de adaptação de sua Constituição a sua realidade. É a única Constituição sintética, porque a mais sintética de todas, que é a inglesa, não existe, não está escrita. Aí, sim, se vai ao extremo no poder permanente de modificação da ordem constitucional dentro das tradições, porque são países que dão tremenda importância à Common $\operatorname{Law}^{17}$ e aos costumes.

No nosso caso, o que se pode discutir é se a Constituição pode ser programática ou não, se ela deve de verdade estatuir coisas que são perfeitamente aplicadas de imediato, ou coisas que são um programa, que está implícito numa série de normas. Tenho a

\footnotetext{
${ }^{16}$ Para Florestan Fernandes, o debate em torno da natureza da Constituição evocava uma nação em conflito, tanto em função dos distintos interesses entre as classes e setores de classe no campo social e econômico, quanto em relação à ordem institucional e ao futuro das liberdades democráticas. Em seu discurso indicava a participação alcançada como condição essencial para prognosticar uma mudança da natureza da democracia, ampliando-a. Assegurar na Constituição os direitos democráticos e sociais seria, naquela conjuntura, uma forma de promover justiça social e fortalecer a democracia.

17 Common Law é uma expressão utilizada nas ciências jurídicas e diz respeito a um sistema de Direito cuja aplicação de normas e regras são mais sancionadas pelo costume ou pela jurisprudência, ao contrário dos preceitos legais antecipadamente fixados, como ocorre no sistema romanogermânico, utilizado por vários países, entre eles o Brasil. (Santiago, s/d)
} 
impressão de que o debate que se realiza atualmente nesta Casa está indicando a necessidade de cobrir uma superfície muito grande com esta Constituição. Seria uma decepção muito grande para o povo brasileiro se não se fizesse nenhuma referência, por exemplo, ao problema dos negros no Brasil; seria uma decepção para outros segmentos importantes se não se tocasse na questão dos deficientes, e por aí adiante. Portanto, o desafio que se coloca é exatamente esse, de como numa linguagem constitucional, que tem que ser uma linguagem elevada ao nível de abstração, onde a forma é tão importante, alcançar uma grande abrangência.

O problema que se coloca para mim é de como conciliar a abrangência com a síntese, e não, digamos assim, imaginar uma síntese excludente de muita coisa que está nas expectativas do povo brasileiro neste momento (ANC, 1988b, p. 424).

Celso Furtado reconhecia que a Constituição deveria resolver uma das características do regime militar, em que somente a minoria dos atores sociais era democrática, sendo a grande maioria não democrática, apenas antiautoritária. O problema é que a transição brasileira apresentava continuidade com o regime militar autoritário em uma série de dimensões importantes: o pacto era feito com tudo e com todos, incluindo os egressos do regime militar, aliás, esta foi uma especificidade do processo político do qual fez parte a Constituição. O segundo ponto, imediatamente articulado ao primeiro, era o que dizia respeito à definição dos objetivos em jogo. Por fim, outro aspecto que não passou despercebido para Fernandes e Furtado foi a ilusão da unidade. É esta a chave em que foram nomeados os negros e os "deficientes". Ao continuar seu discurso Furtado concluiu:

Portanto, no Ministério da Cultura que eu entendo, a minha grande ambição, minha grande preocupação, é conseguir que a população, essas forças todas, vale dizer de ruptura, que são jovens, que são os movimentos feministas, os movimentos dos negros, toda essa força de ruptura hoje em dia, e que refletem a tensão que existe nos controles sociais que sobre eles prevaleceram tanto tempo, que essas forças encontrem possibilidade de ser, de se manifestar, e de abrir espaço para que possa o processo criativo abrir a sua superfície de ampliação.

Essa é a nossa filosofia última e creio que se a Constituição também se voltará para isso para a valorização daquilo que é contestação, que é ruptura e que, portanto é o começo de algo novo, e a negação que dentro de uma dialética é a coisa mais criativa que a negação; se nos voltarmos para isso, creio que seria uma Constituição altamente moderna e estaríamos dando exemplos a muitos povos, essas classes oprimidas que são agentes históricos, como dizia Florestan Fernandes, e que tiveram um papel importante, mas, quase sempre oculto, escondido dentro da vida. 
Por último, eu diria que é um grande orgulho para mim pertencer a uma geração que trouxe o Brasil a este processo Constituinte.

Vivi bastante para dizer que não imaginava ter essa satisfação tão completa, é ver toda a sociedade se reunir aqui, expor seus pontos de vista, esses milhares de papeis que aqui chegam e que a primeira vista parece uma inundação, mas, na verdade é a expressão de um profundo desejo de participação. Creio que nenhum lugar do mundo houve uma Constituição feita com tanta participação como se está fazendo hoje no Brasil e a forma como foi organizado o trabalho, com essa pluralidade de grupos trabalhando e com tanta abertura a todos, isso creio que foi de verdade um fato histórico que vai marcar nossa vida. (ANC, 1988b, p. 425).

O debate entre Florestan e Celso Furtado teve relevância particular. Dois intelectuais de importância singular, cuja produção, tanto no campo da sociologia quanto da economia, é indispensável para a compreensão do Brasil, discutiram a partir de lugares institucionais e políticos distintos: Florestan, como deputado federal do PT, e Celso Furtado, como Ministro da Cultura de um governo sustentado pelo PMDB e pelo PFL. O debate entre ambos reflete muito mais do que a posição das forças políticas que eles representavam, trazendo a compreensão sobre o lugar do intelectual naquela conjuntura e utilizando concepções do campo da sociologia e da economia sobre o capitalismo em escala mundial e sobre o Brasil.

A manifestação final de Celso Furtado na Subcomissão reforçava a intenção de fortalecer a voz dos inúmeros setores sociais que, silenciados durante os anos de ditadura, se organizaram para apresentar suas propostas aos constituintes. Tal perspectiva está relacionada à compreensão do então Ministro acerca da política concebida como se constituindo em possibilidade de formação da consciência crítica sobre o capitalismo como sistema global e da rejeição radical às formas de vida criadas pela civilização ocidental (Bolaño, 2013).

Vale uma pequena digressão para localizar o pensamento do economista Celso Furtado acerca da ação política, da cultura e da criatividade, constituídos como campos indissociáveis. Ao buscar compreender os nexos entre criatividade cultural e capitalismo dependente, ele indicou que o desenvolvimento pressupunha a utilização de um excedente, cuja existência daria impulso à criatividade. Assim, o processo cumulativo em relação às forças produtivas teria permitido à burguesia destruir outras formas de produção, impulsionando o nascimento do capitalismo. É exatamente esse processo de acumulação que permitia a reprodução da estrutura de dominação para apropriação do excedente social, condição de manutenção e 
reprodução da ordem capitalista. Nesta chave de pensamento, a história da civilização é a crônica da subordinação progressiva de todas as formas de atividade criativa à racionalidade instrumental, incluindo a pesquisa científica posta a serviço da inventividade técnica que, por sua vez, estava a serviço da acumulação. (Furtado, 2012)

A criatividade artística conheceu uma evolução similar e, progressivamente, se colocou a serviço do processo de diversificação dos padrões de consumo enquanto instrumento da acumulação. Os laços da criatividade com a vida humana considerada como um fim em si mesmo se enfraqueceu, e as inculcações dessa criatividade com os instrumentos que asseguravam a acumulação se hipertrofiaram consideravelmente. De maneira geral, todas as formas de criatividade humana podem ser postas a serviço da acumulação. Contudo, aquelas cujos resultados são cumulativos por natureza - quer dizer, a ciência e a tecnologia - são as que melhor satisfazem as exigências de tal processo, o que faz por merecerem o lugar privilegiado que ocupam na civilização industrial. (Furtado, 2012)

Ao operar com certa autonomia entre as dimensões social e econômica, Celso Furtado considerava que as formas sociais constituíam uma dimensão da invenção cultural, em que os fins não podem ser facilmente eliminados. Por tal razão, a esfera da política seria um espaço catalisador de forças criativas para levar a efeito os fins da vida humana em sociedade. Porém, nas chamadas sociedades dependentes, a atividade política não teria a mesma capacidade propulsora, seja porque na etapa primário-exportadora a atividade política teria se limitado à luta pelo excedente econômico, seja porque a industrialização, em condições de dependência, não conduziria a formas sociais estáveis ou capazes de gerar uma consciência crítica reguladora. Essa condição limitaria a inventividade no plano político e o próprio desenvolvimento como expressão da criatividade de tais sociedades.

Quanto a Florestan Fernandes ${ }^{18}$, ele defendeu na Subcomissão da Educação, Cultura e Esportes uma constituição analítica e detalhada, como forma de resolução

\footnotetext{
${ }^{18}$ Florestan Fernandes (1920-1995) foi a "figura de intelectual que quis e conseguiu ser militante e estudioso em tempo integral; e que assumiu o papel de Dom Quixote da sociologia crítica em tempos, adversos tanto às ciências sociais quanto à resistência política [...] ele pretendeu perfazer a quadratura do círculo e fazer com que a instituição universitária servisse, como ele, em tempo integral, não aos intelectuais que dela vivem ou nela vegetam, mas àqueles que, sabidamente, não
} 
de conflitos e garantia de direitos historicamente não assegurados. Tornou explícita sua posição em relação ao acolhimento das demandas sociais e ao fortalecimento das lutas e do processo de participação social, salientando que a luta pelo poder político representava a luta pelo controle social sobre o alcance das transformações sociais e do processo de desenvolvimento, em termos nacionais e civilizatórios. Para Florestan, o compromisso com uma constituição detalhada e analítica, em particular no caso da educação, expressava a visão de que o desenvolvimento não poderia ser tratado de maneira exclusiva como questão econômica, social, política ou mesmo como questão cultural de maneira isolada. Ao considerar o desenvolvimento como uma questão macrossociológica que afetaria todas as dimensões do destino nacional, Florestan vinculou a sua efetividade à transformação da ordem, de modo a tornar equitativos os direitos em termos sociais e regionais, bem como a participação nas estruturas de poder.

Uma segunda manifestação representativa da "perspectiva analítica" foi a do então Ministro Celso Furtado. Ao considerar a natureza da constituição como o problema maior a ser definido no processo constituinte, manifestava preocupação com a possível ausência de tratamento de temas apontados como urgentes por diversos setores sociais. Na sua produção intelectual destacava que, além das elites, era preciso que novos sujeitos se manifestassem na vida política e social, operando rupturas nas estruturas herdadas no campo econômico e político, criando possibilidades para que o desenvolvimento vindouro estivesse fortemente associado a perspectiva de criatividade, concepção estruturante do pensamento do autor.

tiveram nem têm acesso aos seus bens; aqueles que ele gostava de nomear, com uma forte expressão latinoamericana, los de abajo [...]." Florestan, construtor de uma obra-vida notável, "uma luminosa carreira [...] do ponto de vista científico e [...] um marxista enriquecido pelas experiências de outras teorias. [...] um dos maiores intelectuais brasileiros que neste século estudaram a sociedade, da mesma importância que Euclides da Cunha, Gilberto Freyre, Caio Prado Júnior, Sérgio Buarque de Holanda." Florestan, "na entrevista que concedeu à Folha de São Paulo pouco antes de falecer, respondendo a uma pergunta sobre a globalização da economia, afirmou: 'Os efeitos previsíveis desse processo em marcha é a herança bárbara que se choca com as aspirações de igualdade, liberdade, democracia, cidadania, universalização da educação de qualidade e tudo o mais'. [...] E, em seguida, aponta o caminho que se apresenta como alternativa a essa tendência de barbarização: 'Os socialistas não são, como muitos insistem, equivalentes dos dinossauros em busca de nova glaciação. Ao contrário, detêm os meios de análise dos processos que estão em efervescência e, ao mesmo tempo, lutam pelas alternativas que restam à humanidade em virtude da incapacidade do capitalismo de responder positivamente às exigências mínimas do viver coletivo com dignidade'. [...] A prática educativa, a produção científica, a militância incansável e a tenaz ação do publicista Florestan Fernandes permanecem como uma contribuição inestimável e sua figura coerente e íntegra constitui um exemplo a impulsionar as lutas que somos impelidos a continuar travando para criar uma sociedade capaz de atender 'às exigências mínimas do viver coletivo com dignidade' entre as quais se inclui a "universalização da educação de qualidade'." Florestan militante-educador. (Bosi, 1996; Cândido, 1996; Saviani, 1996) 
Percorrendo os possíveis caminhos de ruptura, destacamos a relação entre a valorização de experiência de auto-organização da sociedade e sua compreensão sobre o sentido da atividade política como espaço de canalização de suas forças criativas. Nesse caso nos ocupamos de explorar a compreensão, por ele desenvolvida, de que a atividade política de diferentes setores sociais tornar-se-ia um poderoso instrumento de crítica à burocratização e ao que considerava a tragédia da civilização ocidental: subordinar os meios aos fins, isto é, a criatividade, as necessidades e a liberdade humanas à lógica da racionalidade instrumental dos processos de acumulação capitalista. Nesse contexto, examinemos a noção de ruptura e consciência crítica nas sociedades de industrialização dependente.

Celso Furtado considerou que nessas sociedades, estando as transformações estruturais vinculadas à transferência de técnicas e tecnologias produzidas em países de acumulação avançada, configurava-se o dilema da não existência de formas sociais estáveis. Antes, as sociedades de economias dependentes estariam propensas às experiências autoritárias de governo, o que comprometeria a formação da consciência crítica e sua expressão no plano político. No que se refere ao processo constituinte a expressão política dos movimentos populares estava claramente identificada com a negação da experiência de autoritarismo no Brasil e, por isso, diretamente relacionada com a possibilidade criativa do desenvolvimento.

O debate sobre a natureza da Constituinte permitiu a expressão de diferentes leituras sobre o passado recente, sobre o significado da ditadura e seus fundamentos doutrinários, sobre os projetos para o país em todas as áreas e sobre as ideias em relação à nação e à cidadania. Deste modo, era desconstituída a ideia de povo difundida, em particular, pela Doutrina de Segurança Nacional, uma vez que legitimava a manifestação de diferentes setores da sociedade que despontavam socialmente como movimentos de massa desde o final da ditadura ${ }^{19}$. Ao reconhecer

\footnotetext{
19 A Escola Superior de Guerra, em 1975 e em 1979 definiu em seus manuais o povo como um dos fundamentos da "Expressão Política do Poder Nacional", assim como o "Território e as Instituições Políticas". O povo, definido em função da existência do Estado-Nação, é o recorte nacional da população, foco principal de atenção da doutrina. Destacam-se do "povo" as elites, a quem cumpre "não só o papel de intérprete dos interesses e aspirações nacionais, para levá-los ao nível da formulação governamental dos Objetivos Nacionais, como o papel inverso de, precisamente em razão da superior qualidade, presumida, de sua formação e informação, infundir e difundir no povo os altos valores da consciência social e a melhor percepção dos autênticos interesses e aspirações". (Escola, 1975, p. 40) O conceito de povo enfeixava e sintetizava um conjunto de matrizes de pensamento do início do século que, apoiadas no evolucionismo, no organicismo e no positivismo, tornavam o "povo"
} 
e legitimar as manifestações, reivindicações e proposições de vários setores sociais, Florestan Fernandes pretendia que o processo constituinte tivesse como decorrência o estabelecimento de determinações e garantias voltadas à ampliação dos direitos em todas as esferas da sociedade, sobretudo dos desfavorecidos.

A experiência de organização e diálogo inseriu centenas de jovens, trabalhadores e setores excluídos da sociedade no debate sobre os destinos das políticas públicas, da política econômica, da legislação de exceção, do papel dos poderes da República, do Estado e de suas Forças Armadas, do fortalecimento das instituições e da legislação democrática. $O$ debate no interior da Assembleia Nacional Constituinte fortaleceu a experiência de participação social e proposição, e permitiu prospecções, como a de Florestan, acerca da organização dos setores oprimidos, conforme escreveu em maio de 1987:

Nesta fase, na qual se realiza uma espécie de auditoria do Brasil real, a pressão política desenrola-se no nível das subcomissões, com lances por vezes emocionantes, pungentes e memoráveis. Por várias vias, gente de diversas categorias sociais, profissionais, étnicas e raciais surge no centro do palco e assume o papel de agente, de senhor da fala. Um indígena, um negro, um portador de defeito físico, um professor modesto, saem da obscuridade e se ombreiam com os notáveis, que são convidados por seu saber ou lá comparecem para advogar as causas das entidades mais ou menos empenhadas na autêntica revolução democrática. O "lobismo" encontra, assim, um antídoto, e os constituintes são devolvidos ao diálogo com o Povo, agora não mais à cata de voto e em busca de eleição. Essas pessoas atravessam as portas do Parlamento como paladinos de causas particulares de alto significado nacional. Não se apresentam para cobrar "promessas eleitorais". Desfraldam as bandeiras das grandes esperanças e das grandes ilusões, combatem por utopias e lutam pelo nosso futuro literalmente, põem os constituintes diante das exigências que o fisiologismo, a debilidade e a ausência de programas dos partidos afugentaram do debate constitucional. Enfim, vemos o mundo pelo avesso! O Povo inunda a ANC e abarrota as subcomissões de propostas, de informações e de sonhos. O subterrâneo sobe à tona em todo o seu esplendor e sublinha 0 quanto o nosso Estado é pobre e o nosso Governo, mesquinho! [...] O "lobismo" vencerá a batalha? Ou o povo abriu as comportas da história em processo de uma vez por todas? Na verdade, nem todas as subcomissões tiveram a mesma sorte. Algumas só estão sofrendo a forte pressão do "lobismo". Noutras, este não foi esmagado; apenas teve seu espaço reduzido. Não obstante, os constituintes dispõem de maior flexibilidade para enfrentarem as correntes internas do forte conservadorismo imperante nos partidos da ordem e

antes como tributário de uma "mística nacional", núcleo do nacionalismo defendido pela ESG, do que fundamento do exercício do poder. Para aprofundar o tema ver Rocha (1996, p.77-87). 
a opacidade burguesa, que se oculta habilmente por trás do manto protetor do reacionarismo político. (Fernandes, 1989, p. 87-8).

As manifestações de Florestan Fernandes (PT-SP) e do Ministro da Cultura, Celso Furtado, reconheciam as diferenças culturais e sociais que expressavam a heterogeneidade da sociedade, reconhecendo as diferenças sem tratá-las como desigualdades, e demonstravam a singularidade histórica de haver "várias nações" no interior da nação, interagindo no espaço público para elaborar uma Constituição, mesmo que as novas relações democratizantes não apresentassem uma relação clara com uma ordem política mais democrática. Na mesma direção, o Ministro da Cultura Celso Furtado destacou a necessária distinção entre formas arcaicas e modernas de fazer política convergindo para a vergonha ou o ufanismo de nossas elites ao pensarem o Brasil. Cito:

As elites brasileiras não ficavam no Brasil, os nossos autores, com a melhor das intenções na verdade se não se envergonhavam do Brasil, pelo menos não consideravam, não acreditavam no Brasil, senão na vertente do ufanismo completo. Era a ideia que se dizia, como o Professor Gudin, que o Brasil não tem cultura porque não tem carvão, não tem recursos complementares, e outros que diziam simplesmente que era um país de mestiços, que será sempre uma cultura secundária, caudatária de outros. Os grandes autores do Brasil - não vou citar nomes, mas me acostumei a ler os autores do Brasil. Nós, da nossa geração, acreditamos na cultura do Brasil, influenciada pela corrente de 22 e pela descoberta de outras formas de pensamento.

Portanto, nós sempre estivemos ligados, ao acreditar no Brasil, em pensar em termos de rupturas ou coisas estabelecidas, cristalizadas no passado. Éramos uma geração que acreditávamos nos processos históricos, inclusive nas rupturas históricas. Grande parte de nós acreditava realmente que o processo revolucionário é uma das formas como o homem constrói o homem. Tudo isso foi uma época em que vivemos essa ideia de ruptura, de reforma gradual ou estrutural que fosse existir uma ruptura maior revolucionária. Estávamos todos buscando a mesma coisa, que era construir outro país, a partir dele mesmo, isso é que é estranho, a partir dos autênticos valores, dessas massas de oprimidos, dessa cultura latente, dessa força criativa, desse povo brasileiro que nós acreditávamos, se não acreditava no povo acreditava no Brasil.

Eu diria que nas condições mais favoráveis, que eu creio que está no pensamento do Constituinte Florestan Fernandes, é que se houvessem liberado condições ótimas para fazer uma Constituição e para fazer reformas e abrir espaço para uma transformação mais rápida do Brasil.

$\mathrm{Na}$ realidade, teremos de considerar isso de vários ângulos, infelizmente não há tempo para abordar o assunto. 
Mas, a primeira consideração que temos que fazer é que nós vivemos num mundo que se contrai, que vai se reduzindo, um mundo demasiado interdependente, a humanidade hoje em dia está num barco só.

Há muitos processos históricos que estão por cima de nós e do qual nós não podemos escapar, nenhum povo moderno pode escapar.

A verdade é que a premência da tecnologia na nossa civilização, a revolução de Informática hoje em dia abre outras brechas e consequências que nós sabemos.

A permanente, hoje em dia, interdependência de espaços culturais que estamos sujeitos que criou a grande indústria da cultura que faz com que nós estejamos lendo aqui o best seller que o alemão está lendo, o Japão está lendo no mesmo ano.

Tudo isso faz com que uma visão do Brasil de hoje não pode deixar de ser primeiramente uma visão que parta da nossa condição de mundo, membros de uma comunidade internacional que é altamente interdependente, portanto, 0 que nós temos que buscar primeiramente é espaço neste mundo internacional através de alianças com os países da América Latina, com os países do Terceiro Mundo, com outros países, buscar formas de poder no plano internacional para preservar a nossa autonomia de decisão e nossa própria identidade.

Isso aí a Constituição evidentemente tem que pensar nisso, no Brasil como uma Nação do mundo moderno.

Em segundo lugar, nós temos que de verdade romper e temos que abrir esses espaços novos, às forças criativas de nosso povo, e finalmente ao nosso povo que é portador de valores e que demonstrou já uma grande força criativa. (ANC, 1988b, p. 425)

O Ministro, prosseguindo em seu diálogo com o deputado Florestan Fernandes, indicava uma alternativa de poder para a sobrevivência e afirmação da nação e de ruptura com o que denominou tradição elitista.

O debate desenvolvido na subcomissão em torno da natureza da Constituinte nos desafia a compreender o conteúdo dos confrontos e convergências políticas no âmbito das estruturas discursivas, e que se deu em distintos momentos no interior da Subcomissão. Especialmente as entidades ligadas à área de educação exerceram forte influência sobre os membros da Subcomissão e contribuíram para o diálogo e a negociação entre parlamentares de partidos com perfis antagônicos. Pode-se dizer que, no caso da Assembleia Nacional Constituinte, a conformação de um campo de educadores foi, de certa forma, o elemento decisivo para os resultados a que chegou essa Subcomissão. A aglutinação dos parlamentares em posições específicas, por meio de blocos em torno de posições nem sempre coincidentes com as das maiorias partidárias, configurou aquilo que o Deputado 
Florestan Fernandes (PT-SP) denominou de "oportunismo construtivo" e que favoreceu negociações e tornou flexíveis as posições quanto a pontos não decisivos para o controle das classes sociais sobre o aparelho estatal e no domínio da economia (Sousa Júnior, 1998, p. 56).

A perspectiva de formação de um bloco progressista não oficial na Subcomissão, de acordo com Florestan, deveu-se ao fato de uma parcela significativa de seus membros integrar a área da educação e ter, por isso, um domínio da pedagogia que lhes permitiria ir além da média do pensamento conservador brasileiro (Ibidem). Ainda segundo o sociólogo, a formação de tal bloco tinha relação com o fato de parte significativa dos membros da comissão ser formada por educadores e intelectuais que trabalharam com pesquisa, com educação e cultura de diferentes gerações de crianças e jovens ou ainda na gestão de entidades e secretarias de educação. Estas experiências os aproximariam tanto dos domínios da razão crítica quanto das necessidades e temas relativos à garantia social do direito à educação.

Ainda mais relevante foi o papel do PMDB na Comissão de Educação, Cultura e Esportes, expressando sua política no contexto da transição. Tal política teve caráter singular porque o PMDB presidia a Subcomissão de Educação ${ }^{20}$, tendo sob sua responsabilidade a relatoria dela, a maioria dos membros efetivos e suplentes, ao mesmo tempo em que foi sustentáculo da Aliança Democrática no governo da Nova República. É necessário observar que a estratégia de construção da Aliança Democrática e a condução da transição no Brasil desde 1984 não envolveu diálogo social, permanecendo fiel à decisão dos militares e dos setores conservadores de dirigir e controlar, de forma lenta e gradual, o processo de transição.

Não obstante tenha o PMDB recebido em seu interior forças políticas e sociais que sustentaram a ditadura - além de integrar a Aliança Democrática (AD) com o PFL, que abrigava vários dirigentes da antiga Aliança Renovadora Nacional (Arena) e do Partido da Democracia Social (PDS), ambos partidos comprometidos

\footnotetext{
${ }^{20}$ A Subcomissão foi composta por 46 parlamentares constituintes, 25 titulares e 21 suplentes. O Partido do Movimento Democrático Brasileiro (PMDB) e o Partido da Frente Liberal (PFL) ocuparam 37 das 46 cadeiras da Submissão. O PMDB controlou a presidência e a relatoria. A $1^{\mathrm{a}}$. e a $2^{\mathrm{a}}$. vicepresidência ficaram, respectivamente, com o Partido Democrático Social (PDS) e o PFL. O Partido Democrático Trabalhista (PDT) esteve representado por um parlamentar. O PDS, o Partido Liberal $(\mathrm{PL})$, o Partido dos trabalhadores (PT) e o Partido Trabalhista Brasileiro (PTB) com dois representantes: um titular e um suplente.
} 
com os governos militares no Brasil -, sua condição no interior da AD expressava um paradoxo incontornável, qual seja, o de se constituir em depositário das esperanças de mudança. O discurso sobre a premência de mudanças no país, associado aos resultados das eleições de 1974 nos marcos do bipartidarismo, acentuou a condição de frente de oposição do MDB, e fez crescer esta percepção no imaginário social. Em outras palavras, os laços e compromissos programáticos assumidos vincularam a imagem do MDB à luta pelo fim da ditadura no Brasil.

Esta condição se transformou, na medida em que a reforma e a liberdade partidária permitiram a organização e a expressão política de vários setores e a formulação de projetos, ao mesmo tempo em que diferentes setores se organizavam em entidades representativas e movimentos, confrontando concepções e propostas. No entanto, os compromissos políticos assumidos pelo Movimento Democrático Brasileiro (MDB) (depois Partido do Movimento Democrático Brasileiro - PMDB) estariam também na raiz da ambivalência de suas posições e práticas no interior da Constituinte, pois ao mesmo tempo em que o PMDB integrava um governo de transição controlada e negociada, operava publicamente uma espécie de acerto de contas com seu próprio programa de mudanças na Constituinte que, tendo como objetivo fundamental reordenar o país catalisou as energias e expectativas de mudanças $^{21}$.

No caso da educação, o debate envolveu diferentes e complexos temas desde seu papel na preservação do patrimônio cultural e na construção da cultura até o aprimoramento do homem e da sociedade - além de seus objetivos, organização, condições de gestão e financiamento, em que a participação social foi intensa, com a apresentação de propostas e fundamentos tornando necessários o diálogo e a negociação. Nestas circunstâncias, torna-se evidente como os movimentos dos partidos não foram lineares, particularmente, os do PMDB.

\footnotetext{
${ }^{21}$ Em 1982, o PMDB apresentou ao país o documento Esperança e Mudança: uma proposta de Governo para o Brasil que resultou de um conjunto de discussões desencadeadas a partir de estudo anterior, produzido para a Convenção de novembro de 1981. O documento indicava quatro campos de proposições: O PMDB e a Transformação Democrática; Uma Nova Estratégia de Desenvolvimento Social, Diretrizes para uma Política Econômica; e A Questão Nacional. Em relação à educação, o diagnóstico apresentado considerava o acesso ao conhecimento como privilégio de poucos e indicava a necessidade de ensino gratuito em todos os níveis e a democratização do acesso ao saber. Com forte teor antiliberal, desenvolvimentista e nacionalista, o documento apresentava um conjunto de diretrizes para que se alcançasse no país uma educação autenticamente democrática (Fagnani, 2005, p. 89-90).
} 
Por tais razões, as análises que consideram o processo constituinte exclusivamente como um conflito entre "elites conservadoras" e "progressistas transformadores" a partir das filiações ideológicas e partidárias mostra-se insuficiente para que se compreenda o contraditório caminho de elaboração das definições constitucionais em relação à educação. Vale observar ainda que não apenas as forças populares ocuparam o Congresso, como demonstrou Antonio Sergio Rocha:

Forças Armadas, membros do Judiciário, polícias, representantes de bancos, de entidades patronais, estatais, multinacionais, mineradoras, etc. transitaram com desembaraço pelos corredores e dependências do Congresso Nacional. Nessa fase estima-se que 9 milhões de pessoas tenham passado pelo Congresso e, ao todo, mais de 60 mil propostas de segmentos diversos da sociedade civil seriam apresentadas às subcomissões da ANC. (Rocha, 2013, p. 734).

Assim, as relações dos deputados e partidos foram marcadas por confrontos e construção de consensos que envolveram intencionalidades e projetos comprometidos com os diferentes interesses das classes sociais em movimento. Tais interesses tiveram recortes específicos quanto às questões raciais e étnicas, de gênero, regionais e setoriais, bem como múltiplas representações em movimentos sociais e em entidades; na defesa de direitos sociais, humanos e civis; na defesa de propostas sobre a organização e defesa do Estado e sobre as instituições democráticas; na defesa de concepções sobre os Poderes e sua organização e sobre os recursos do país; sobre os interesses e a ordem econômica e financeira; sobre o sistema tributário nacional e as finanças públicas; e sobre a herança social e institucional deixada pelos governos militares. Também é necessário considerar que:

As dificuldades que a agregação de apoios e os entendimentos
parlamentares enfrentam nâo se explicam somente pelo
"continuísmo" ou por uma unidimensionalidade ideológica das elites
políticas que dele se infere. A causalidade linear estabelecida entre
origens sociais e crenças políticas é reconhecidamente insuficiente
em termos de sua capacidade preditiva [...]. A ênfase dada a um
genérico continuísmo conservador é, de modo claro, empobrecedora
para a compreensão de tais posições e insuficiente para explicar o
conflito parlamentar. (Souza, 1988, p. $570-1$ )

As formulações e as conclusões apresentadas no debate da Subcomissão sobre financiamento da educação, em termos da utilização dos recursos públicos, 
revelam muitas das ambivalências e contradições que caracterizaram o processo de elaboração do capítulo da educação.

Ao apresentar essa proposta de Constituição, Florestan Fernandes colocava em pauta o jogo das tensões sociais, apontando a insuficiência do juridismo. No seu entendimento, era a realidade social que criava a lei, e não o contrário, e para romper certo alheamento em relação às demandas sociais da maioria da população marcada pela heterogeneidade, buscava assegurar que os interesses privados e conservadores - e seus porta-vozes na sociedade e no parlamento - não deslocassem as decisões para o âmbito da legislação infraconstitucional ou para outros atos de menor força normativa e de vigência com menor alcance. A emergência de novos movimentos sociais e de entidades mais diretamente envolvidas como atores do processo constituinte criavam a necessidade de incluir nos debates as transformações de natureza social e econômica, além de construir um acordo sobre o funcionamento das instituições, descortinando um novo horizonte de possibilidades.

A Assembleia Nacional Constituinte propôs, por meio de seu Regimento Interno, três formas de participação do eleitor e de setores representativos da sociedade. A primeira facultava às Assembleias Legislativas, Câmara de Vereadores, tribunais e entidades representativas de segmentos da sociedade civil apresentação de sugestões a ser endereçada ao presidente da Assembleia Nacional Constituinte e por ele remetidas às respectivas Comissões, conforme artigo 13, § 11 . A segunda, de acordo com o artigo 14, previa que as Subcomissões destinassem cinco das oito reuniões para audiência com entidades representativas dos segmentos da sociedade. E a terceira assegurava que, em prazo determinado, poderia ser feita a apresentação de proposta de emenda ao Projeto de Constituição, desde que subscrita por trinta mil ou mais eleitores brasileiros, em listas organizadas por, no mínimo, três entidades associativas que deveriam se responsabilizar pelas assinaturas. (ANC, 1987)

Pela primeira vez essa participação direta era praticada no Brasil, embora esse direito não tenha sido inédito, uma vez que foi garantido, como parte do Regimento Interno da Constituinte de 1823, que o cidadão representasse o que julgasse proveitoso à nação por meio do Presidente da Assembleia, de secretários ou deputados. Mas são situações marcadamente diferentes, considerados os 
contextos históricos e a própria natureza do Regimento. O Império, sob a influência do liberalismo europeu, abriu espaço apenas para a participação da oligarquia, tanto assim que o Regimento de 1823 proibia ações coletivas e representações assinadas por mais de uma pessoa, além de não prever discussão ou defesa das propostas. Também os processos constituintes que ocorreram durante a República a partir de eleições livres e diretas não previram em seus regimentos internos a participação direta dos eleitores ou de instituições representativas da sociedade, marcando o autoritarismo de tais processos frente às manifestações de diferentes setores de classe da sociedade em diferentes conjunturas. Como demonstra Renato Soares (1999), em 1934 e 1946 muitos setores sociais se organizaram, não apenas para expressar suas reivindicações e interesses, mas para formular uma proposta de educação pública como direito no país.

Não há dúvida que a participação social ocorrida no processo constituinte de 1988 foi a mais expressiva da história das elaborações das Constituições brasileiras, apesar do empenho das elites econômicas não ter medido esforços para evitar mudanças. Foram apresentadas 122 (cento e vinte e duas) propostas de emendas, que somaram 12.277 .423 (doze milhões, duzentos e setenta e sete mil e quatrocentas e vinte e três) assinaturas ${ }^{22}$. Atentemos para as considerações de Florestan Fernandes:

No seu todo essa é uma situação peculiar. A falta de organização dos partidos da ordem conduziu-nos a um impasse. Ao aceitarem os caminhos da iniciativa popular - o que fizeram porque não possuíam programas e projetos políticos constitucionais propriamente ditos -, permitiram que os cidadãos invadissem a cidadela dos políticos profissionais e desempenhassem, pelo menos por um curto período, os papéis de "representantes do Povo". O dito está dito! Toneladas de papéis desabaram sobre as subcomissões e, agora, não há como ignorar o seu conteúdo. O desafio está lançado! Não há como ignorar o que a maioria espera dos constituintes. Essas são as duas pontas de um dilema político que o conservantismo das classes dominantes não tem como negligenciar. (Fernandes, 1989, p.8)

Neste cenário, o processo constituinte foi o lugar privilegiado para disputar os rumos da organização do Estado, assim como os marcos legais de ordenamento

\footnotetext{
${ }^{22}$ O Regimento Interno da Assembleia Nacional Constituinte previa que cada eleitor poderia assinar até três emendas. Soares (1999) estima que, no mínimo, 6\% do total de eleitores participou do processo.
} 
das políticas públicas e da construção de diferentes discursos sobre o papel do Estado e o resguardo de sua soberania no contexto internacional.

O desafio também é enorme para os que pretendiam uma constituição "enxuta" ou "sintética". Haverá muita decepção, mesmo que o processo constituinte ganhe uma densidade democrática e libertária indiscutível. Procedeu-se a um deslocamento que está indo longe demais. Apesar das discrepâncias e contradições, a voz do Povo reivindica que a Constituição contenha um rol máximo de normas constitucionais. A Constituição se definiu concretamente como uma arma de luta contra o arbítrio. É uma resposta à ditadura e à tutela militar, embutida na "Nova República". Não só se quer explodir a Bastilha - existe o empenho coletivo de se partir de uma posição avançada na prática de uma democracia de participação ampliada.

Enquanto as elites econômicas e políticas das classes dominantes querem brecar o processo constituinte, através do ardil de uma "transição democrática" (delimitada segundo uma equação políticomilitar como "lenta, gradual e segura"), o empuxe que procede da eclosão popular volta-se espontaneamente por um salto qualitativo que remete a uma revolução política [...]. (Fernandes, 1989, p. 88-9)

\section{5 - O Estado entre o público e o privado e as representações da Nação}

A discussão realizada entre os Constituintes nas primeiras reuniões da Subcomissão de Educação, Cultura e Esportes - em particular nas de 21 e 22 de abril de 1987, respectivamente a nona e décima (extraordinária) e décima primeira envolveu a abordagem de objetivos e metas de atendimento educacional público e/ou obrigatório - incluindo os alunos com deficiências e os superdotados -, as competências de cada um dos entes federados e os recursos a serem destinados para que cada um pudesse cumprir suas futuras responsabilidades constitucionais. ${ }^{23}$

Os debates sobre as metas e responsabilidades de atendimento estiveram fortemente relacionados às propostas de ampliação e destinação dos fundos públicos, retomando no país a discussão sobre a relação entre o público e o privado, a partir da ação do Estado e da moldagem legal das questões das constituintes de 1934, 1937 e 1946.

\footnotetext{
${ }^{23}$ A Subcomissão de Educação, Cultura e Esportes realizou 35 reuniões de trabalho entre 07 de abril de 1987, desde a reunião de instalação até a de 25 de maio de 1987, quando foram concluídos os trabalhos.
} 
O processo de elaboração da Constituição de 1934 retomou problemas discutidos na revisão constitucional de 1926, a saber: a educação começou a ser considerada, de fato, um direito, e a União passou a ser a institucional legitimadora de suas práticas. Os temas discutidos nas reuniões iniciais voltaram a ter uma participação mais direta no planejamento e ação supletiva no país. Os entes federados passaram a possuir os meios de efetivar tais direitos, na medida em que ficou determinado, no artigo 156, que a União e os Municípios deveriam aplicar nunca menos que dez por cento, e os Estados e o Distrito Federal nunca menos de vinte, da renda resultante dos impostos, na manutenção e no desenvolvimento dos sistemas educativos. No parágrafo único do artigo ficou estabelecido que, para a realização do ensino nas zonas rurais, a União deveria reservar, no mínimo, vinte por cento das quotas destinadas à educação no respectivo orçamento anual. (Brasil, 1934)

Tais medidas demonstrariam a presença do "movimento renovador da educação" que, desde os anos 1920, realizando a crítica à escola existente, se tornaria um referencial do debate sobre a necessidade de uma escola única, universal, de caráter público, financiada pelo Estado. As expressões mais claras de tal movimento seriam O Manifesto dos Pioneiros da Escola Nova, de 1932, e o anteprojeto constitucional apresentado pela $5^{\text {a }}$ Conferência Nacional da Associação Brasileira de Educação (ABE), de 1933. (Rocha, 2005 p. 121-2)

Pode-se afirmar que a revisão constitucional de 1926 seria um prenúncio do debate que se travaria na Constituição de 1934 visando a superar a condição da educação como privilégio de classe e buscando assegurá-la como direito para todos:

[...] a revisão Constitucional revelou pelo menos dois pontos importantes: o primeiro foi a elucidação do papel da União quanto à instrução básica, quer aceitando que a interferência já estava posta implicitamente em 1891, quer posicionando que tal orientação deveria ficar explícita, não se poderia resolver o "enigma" do caráter nacional sem a presença do Estado. É através da Educação que o Estado se torna demiurgo da nação e sem ele o país ou se cinde pelo regionalismo ou acolhe a "perigosa" idéia de uma revolução internacional. O segundo foi a antecipação de pontos que só se tornariam componentes do pacto constitucional após a Revolução de 1930. Estes pontos serão consubstanciados no capítulo próprio para a Educação reservado na Constituição de 1934. A Revisão de 1926 antecipa em 8 anos a concepção da educação como direito social pelo qual o Estado dá uma resposta, que não é a da "outorga", às 
pressões de vários movimentos civis entre os quais as pressões do operariado. (Cury, 2005 p. 104).

Ao tratar da responsabilidade quanto ao dever de educar, o texto constitucional indicava a prioridade da família, como consta no artigo 149:

A educação é direito de todos e deve ser ministrada pela família e pelos poderes públicos, cumprindo a estes proporciona-la a brasileiros e estrangeiros domiciliados no paiz, de modo que possibilite efficientes factores de vida moral e economica da Nação e desenvolva num espírito brasileiro a consciência da solidariedade humana. (Brasil, 1934)

O texto constitucional indicava no inciso "c" do artigo 150 que haveria "liberdade de ensino em todos os graus e ramos, observadas as prescrições da legislação federal e estadual" (Ibidem). É possível inferir da relação entre as duas determinações que, sendo a família a principal responsável pela educação das crianças e jovens, caberia a ela decidir sobre a educação pública ou privada. Também é certo que no capítulo referente à educação e à cultura estão duas outras definições importantes quanto à relação público e privado, que reforçariam a existência da rede privada de ensino como alternativa de atendimento. Referimo-nos ao artigo 154: "Os estabelecimentos particulares de educação gratuita primária ou profissional, oficialmente considerados idôneos, serão isentos de qualquer tributo" (Ibidem) e ao artigo 152, parágrafo único:

[...] compete precipuamente ao Conselho Nacional de Educação, organizado na forma da lei, elaborar o plano nacional de educação para ser aprovado pelo Poder Legislativo e sugerir ao Governo as medidas que julgar necessárias para a melhor solução dos problemas educativos, bem como a distribuição adequada dos fundos especiais. (Ibidem)

Observe-se que a distribuição dos Fundos Especiais contava com outro ponto de apoio no texto constitucional, a saber, o artigo 157:

A União, os Estados e o Distrito Federal reservarão uma parte dos seus patrimônios territoriaes para a formação dos respectivos fundos de educação.

$\S 1^{\circ}$ As sobras das dotações orçamentárias, acrescidas das doações, percentagens sobre o producto de venda de terras publicas, taxas especiaes e outros recursos financeiros, constituirão, na União, nos Estados e nos Municípios, esses fundos especiaes, que serão applicados exclusivamente em obras educativas determinadas em lei. 
$\S 2^{\circ}$ Parte dos mesmos fundos se applicará em auxílios a alumnos necessitados, mediante fornecimento gratuito de material escolar, bolsas de estudo, assistência alimentar, dentaria e medica, e para vilegiaturas. (Ibidem)

A previsão de concessão de bolsas e as competências do Conselho Nacional em regulamentar os fundos especiais que as financiariam, entre outras atividades, associadas às determinações afetas à existência do ensino privado, permitem entrever a constituição de uma dinâmica de transferência de fundos públicos na sustentação da rede privada.

Não obstante se constate, na Constituição de 1934, a prevalência das propostas presentes no movimento renovador que lançou o Manifesto dos Pioneiros da Escola Nova e, sobretudo, o reconhecimento da educação como direito de todos e da necessidade da escola pública gratuita, obrigatória e laica, é necessário indicar que também compõem o texto constitucional definições voltadas ao atendimento das chamadas carências sociais dos alunos. Destaca-se a destinação de recursos para bolsas de estudo, particularmente para os alunos das instituições privadas. Em 1934, a obrigatoriedade foi estabelecida em relação ao ensino primário e apontada a tendência à gratuidade nos níveis ulteriores ao primário, o que não voltou a acontecer até a Constituição de 1988.

[...] Como se vê, em nenhum momento há qualquer cuidado dos renovadores em dirigir a verba pública para a educação pública. Se assim é nos que defendem e priorizam o ensino público, assim resta no texto constitucional definitivo.

A explicação para essa liberalidade da parte dos renovadores não pode ser buscada num comprometimento ideológico de cunho liberal econômico, até porque não é este o liberalismo que os inspira. A resposta talvez possa ser buscada em Anísio Teixeira [?] que, em época posterior, quando o conflito educação pública versus educação colocou-se francamente, refletindo sobre a gênese da disputa, observou que as escolas privadas do pré-1930 'resistiam vivamente a qualquer intromissão do Estado... (Elas) pensariam em tudo, menos em pedir recursos ao Estado'. [...] De fato, o segmento absolutamente majoritário e expressivo do setor de ensino privado, os católicos, em manifesto à Constituinte nada reivindicam a respeito. (Rocha, 2005, p. 129)

Seja como for, coexistem no texto constitucional de 1934 duas tendências distintas. A primeira estabelece a educação como direito de todos, o que implicaria na superação do paradoxo de uma educação como privilégio de poucos, de 
natureza segregadora face aos desafios do desenvolvimento e da modernização do país. Neste caso, o estudante era concebido como um sujeito de direitos, independente de sua condição social. A segunda concebe o estudante pobre como sujeito de carências a quem - em função de seu talento e com o trabalho da família - o pagamento dos estudos poderia fazê-los bem sucedidos.

Inversamente à compreensão dos renovadores, que não defendiam o monopólio educacional pelo Estado e entendiam como transitória a situação de financiamento público ao chamado aluno carente, matriculado em escola privada, estabeleceu-se uma brecha para uma luta futura, visando a destinar fundos públicos às escolas privadas, o que se tornou possível na Constituição de 1937. Neste novo texto constitucional, em seu artigo 124 , foi acentuado o dever da família em relação à educação, definindo-se que a família seria constituída pelo casamento indissolúvel, sob a proteção do Estado, e que às famílias numerosas seriam atribuídas compensações na proporção de seus encargos (Brasil, 1937). No capítulo dedicado à Família, se afirmava:

Art. 125 - A educação integral da prole é o primeiro dever e o direito natural dos pais. O Estado não será estranho a esse dever, colaborando, de maneira principal ou subsidiária, para facilitar a sua execução ou suprir as deficiências e lacunas da educação particular. (lbidem)

No artigo 129 deste texto constitucional ficava ainda mais claro o papel pontual do Estado e a prevalência do privado na oferta da educação, considerando responsabilidade atribuída à família:

À infância e à juventude, a que faltarem os recursos necessários à
educação em instituições particulares, é dever da Nação, dos
Estados e dos Municípios assegurar, pela fundação de instituições
públicas de ensino em todos os seus graus, a possibilidade de
receber uma educação adequada às suas faculdades, aptidões e
tendências vocacionais. (Ibidem)

O artigo 130 determinava que o ensino primário fosse obrigatório e gratuito, mas não público. Definia ainda que

A gratuidade, porém, não exclui o dever de solidariedade dos mesmos para com os mais necessitados; assim, por ocasião da matrícula, será exigida aos que não alegarem, ou notoriamente não puderem alegar escassez de recursos, uma contribuição módica e mensal para a caixa escolar. (Ibidem) 
A definição da educação como direito natural dos pais parecia alargar a doutrina dos direitos fundamentais do homem, de natureza prescritiva, formulada no âmbito da escola do jusnaturalismo ${ }^{24}$. A educação era associada, no texto constitucional, ao direito à vida, à liberdade, à segurança. A construção ideológica em questão, lançando mão de fundamentos liberais - nos marcos da configuração de um Estado autoritário - fazia retroceder a educação como direito de todos, restringindo sua obrigatoriedade e gratuidade ao ensino primário e, ainda assim, supondo que os não necessitados pudessem encaminhar contribuições para as escolas. A Constituição de 1937 deslocava o papel do Estado, cabendo-Ihe atender prioritariamente aos necessitados.

Não obstante o repúdio do Estado Novo ao liberalismo político e econômico, a ideia de carência encerrava as concepções da fase primeira do liberalismo europeu, que atribuía ao indivíduo a responsabilidade por seu sucesso na vida em sociedade, devendo a autoridade agir apenas para o desenvolvimento das capacidades individuais. Os melhores teriam os recursos necessários para estudar em escolas particulares. A concepção em questão é a de que o poder político, ao fazê-lo, melhoraria a condição material dos mais talentosos e, por conseguinte, faria prosperar toda a sociedade (Laski, 1961 p. 209).

A desobrigação com relação ao direito à educação pública, não implicava, contudo, renúncia à condução da política educacional pelo Estado. Veja-se que, por meio do estabelecido no artigo 129 , pretendia-se direcionar os estudantes pobres para os cursos profissionais de sorte a atender à crescente necessidade de mão-deobra em face dos interesses da industrialização do país.

[...] O ensino pré-vocacional e profissional destinado às classes menos favorecidas é, em matéria de educação, o primeiro dever do Estado. Cumpre-Ihe dar execução a esse dever, fundando institutos de ensino profissionais e subsidiando os de iniciativa dos Estados, dos Munícipios e dos indivíduos ou associações particulares e profissionais.

É dever das indústrias e dos sindicatos econômicos criar, na esfera de sua especialidade, escolas de aprendizes, destinadas aos filhos de seus operários ou de seus associados. A lei regulará o cumprimento desse dever e os poderes que caberão ao Estado sobre essas escolas, bem como os auxílios, facilidades e subsídios a Ihes serem concedidos pelo poder público. (Brasil, 1937)

\footnotetext{
${ }^{24} \mathrm{O}$ jusnaturalismo compreendia que todos os homens tinham direitos pelas leis da natureza e que, por conseguinte, seriam imutáveis, universais e invioláveis.
} 
O substrato dessa concepção era formar uma sociedade estamental por meio de um sistema de educação dual, formando elites dirigentes do Estado, assegurando ao povo as aptidões necessárias para atender às funções econômicas, sobretudo às atividades industriais, que cresciam no país. (Cunha, 1980). Estas elites encarnariam a "mentalidade do homem novo" e estariam aptas a civilizar o povo para fazer prosperar o capitalismo segundo os interesses políticos do Estado. (Pécaut, 1990, p. 67-69).

Este conjunto de questões havia sido retomado quando o presidente Getúlio Vargas, se antecipando à sociedade civil na reivindicação de uma constituinte, começou a articular uma reforma institucional. Embora esta constituinte não tenha sido presidida por Vargas, em grande medida ela foi elaborada como continuidade de uma estrutura de poder que ele havia montado no Estado Novo. Em 1946, no governo Dutra (1946-1951), o então senador Vargas, no papel de mediador, se dirigia aos interesses industriais de São Paulo, às oligarquias do Nordeste, à classe operária e às massas marginalizadas das grandes cidades brasileiras. Todavia, as tensões sociais não foram enfrentadas e entre as causas destas estava a discussão da definição constitucional dos problemas relativos à educação, em particular, mobilizando os debates sobre o dever e o direito de educar no âmbito da relação entre Estado e Família.

O que estava em jogo, mais do que o funcionamento das instituições, eram as transformações de natureza social e econômica. A resposta condicionou, entre outros aspectos, o relativo ao favorecimento da transferência de recursos públicos para as escolas privadas. O relatório da subcomissão que tratou da educação afirmava: "A educação é dever e direito natural dos pais, competindo supletiva e subsidiariamente aos poderes públicos." Duas linhas de argumentos sustentavam esta formulação: a primeira, que caberia à família a responsabilidade de educar por dever e por direito, este, constituindo-se em uma condição inquestionável. Decorrente da primeira, a segunda linha argumentativa indicava que o Estado não podia substituir os pais na educação de seus filhos, ainda que tal perspectiva fosse típica de Estados antidemocráticos que pretendiam "modelar a infância".

Coerente com a abordagem "anti-estatista" e "anti-totalitária", defendia-se o "ensino livre" que, no entanto, não prescindiria do Estado, ao qual caberia subsidiar a escola particular. Assim, o direito natural da família de educar seus filhos seria 
apresentado como uma espécie de variante dos direitos naturais - o direito à vida, à liberdade, à segurança, à felicidade - que, não sendo passíveis de verificação ou questionamento, seria da alçada do Estado. Como ressaltou Bobbio (2013), trata-se de uma espécie de racionalização póstuma dos direitos do homem ${ }^{25}$.

A mobilização da ideia de liberdade como direito natural apresenta claro sentido instrumental, seja porque ignora que os direitos do homem, seja por não considerar os direitos políticos e os direitos sociais. (Laski, 1961). Na Constituinte de 1946, esta mobilização visava a justificar a transferência dos fundos públicos para sustentar os empreendimentos de natureza privada. Aqueles que - como Hermes Lima, da Esquerda Democrática do Distrito Federal, por exemplo - se opunham a essa visão, indicavam que o papel do Estado não deveria ser subsidiário ou supletivo, mas central como o da família. (Lima apud Oliveira, 2005, p. 175)

Oliveira (2005, p. 175-9) demonstrou que, além do subsídio, duas outras formas de repasse de verbas foram cogitadas: o reconhecimento do professor particular autônomo como servidor público, estendendo os benefícios da Previdência Social; e a isenção de impostos, vedando à União, aos Estados e aos Municípios cobrar impostos de instituições de educação e de assistência social, vindo esta última formulação integrar o texto final.

A defesa e a valorização das escolas privadas ficaram mais evidentes quando se discutiu a qualidade do ensino primário. Embora não tenha havido contraposição explícita à obrigatoriedade e à gratuidade desse grau de ensino, neste caso, foram postas em questão a qualidade da educação pública oferecida e a disparidade entre a demanda e o número de escolas construídas, evocando-se nas discussões os índices de repetência e abandono escolar como importante indicador de problemas. (Oliveira, 2005).

Como decorrência, esta discussão ganhou certo consenso em torno do aporte de subsídios à escola privada, prática até então já estabelecida no país. A divergência dizia respeito à tentativa de obrigar os estados e municípios a utilizar

\footnotetext{
${ }^{25}$ A experiência histórica tornou evidente que a condição de servidão dos homens foi superada pela conquista gradual de liberdade e que a doutrina dos Direitos Naturais, como pressuposto filosófico do Estado liberal, inverteu o processo histórico ao considerar a liberdade como estado natural do homem, condição da construção da sociedade política com soberania limitada. Assim a doutrina dos direitos naturais inverteria o curso histórico, colocando o início como fundamento. (Bobbio, 2013, p.14-5).
} 
parte dos recursos vinculados à educação com subsídios. A proposição era de $20 \%$ sobre a receita de impostos para municípios e estados e 10\% para a União, formulação que passou a integrar a Constituição. $O$ argumento contrário mostravase a favor de que a decisão sobre como e quanto investir ficasse sob a responsabilidade dos municípios e estados, não cabendo à Constituição fixar obrigações ou percentuais. Quanto à destinação sobre a utilização dos fundos públicos, tratava-se de deslocar o poder de decisão para as esferas estadual e municipal, na tentativa de evitar confrontos sociais em torno do tema. O texto constitucional promulgado em 18 de setembro de 1946 tratou da questão, no Título VI, da "Família, da Educação e da Cultura".

O artigo 166 afirmava que "a educação é direito de todos e será dada no lar e na escola. Deve inspirar-se nos princípios da liberdade e nos ideais de solidariedade humana." Por sua vez, o artigo 167 indicava que "o ensino dos diferentes ramos será ministrado pelos poderes públicos, e é livre à iniciativa particular, respeitadas as leis que o regulem" (Brasil, 1946). Já o artigo 168 estabelecia entre outros princípios que:

I - o ensino primário é obrigatório e só será dado na língua nacional;

II - o ensino primário oficial é gratuito para todos; o ensino oficial ulterior ao primário sê-lo-á para quantos provarem falta ou insuficiência de recursos;

III- as empresas industriais, comerciais e agrícolas, em que trabalhem mais de cem pessoas, são obrigadas a manter o ensino primário gratuito para todos os seus servidores e os filhos destes;

IV - as empresas industriais e comerciais são obrigadas a ministrar, em cooperação, aprendizagem aos seus trabalhadores menores, pela forma que a lei estabelecer, respeitados os direitos dos professores. (Ibidem)

No que se refere ao artigo 170, o sistema federal de ensino teria caráter supletivo, devendo se estender nos limites das deficiências locais. E o artigo 171 definia que os estados e o Distrito Federal deveriam também organizar seus sistemas de ensino, e que o auxílio pecuniário da União para o ensino primário proviria do Fundo Nacional. (Ibidem)

Observe-se a ambiguidade da garantia da educação no texto constitucional, na medida em que oscilava entre o reconhecimento deste direito social como universal e obrigatório por parte do Estado (como o ensino primário) e como 
responsabilidade privada, no caso dos níveis ulteriores de ensino. Embora não houvesse referência explícita à responsabilidade privada, esta era uma condição facilmente dedutível, porquanto o texto constitucional apontava que o papel do Estado, no caso da oferta dos níveis de ensino subsequentes ao primário, seria o de garantir o acesso apenas aos estudantes que comprovassem a falta ou insuficiência de recursos para cursarem escolas privadas. Significa dizer que 0 texto constitucional reconhecia o direito universal e atribuía sua garantia ao Estado ao mesmo tempo em que substituía a ideia de direito pela de carência e/ou necessidade, dilema nada singular na história das constituições brasileiras.

O exame dos capítulos relativos à educação nas Constituições de 1934, 1937 e 1946 aponta a historicidade das definições sobre direitos e sobre a luta por sua garantia, de vez que os textos legais resultam do confronto de interesses econômicos e sociais expressos e dinamizados no plano político. Nesta linha de pensamento, os direitos civis fundamentais (o direito à vida, à liberdade individual, à propriedade e à igualdade perante a lei), os direitos sociais (direito ao trabalho, a um salário justo, à cultura, à educação, saúde, moradia e proteção social, entre outros) e os direitos políticos (fonte de legitimidade do poder) são partes constitutivas da condição humana. São fenômenos históricos, e sua reivindicação e conquista são políticas. Decorrem do reconhecimento de necessidades e carências, e são estabelecidos no contexto dos conflitos e lutas travadas em uma sociedade. Assim, conforme Bobbio, os direitos não pertencendo,

[...] a um homem abstrato e, como tal, subtraído ao fluxo da história são o produto não da natureza, mas da civilização humana; enquanto direitos históricos eles são mutáveis, ou seja, suscetíveis de transformação e ampliação. (BOBBIO, 1992, p. 32).

No Brasil, a questão da naturalização dos direitos ou das carências como dupla face do discurso liberal assumiria forma específica na constituição de 1967, e depois em 1969, porque subordinada a perspectiva da Segurança Nacional como política do Estado brasileiro. Tratava-se de dar estatuto normativo aos princípios da doutrina militar da Escola Superior de Guerra que inspiraram as ações repressivas e as políticas do Estado. A Constituição de 1967 definia, em seu artigo 167, que a família seria constituída pelo casamento e que teria a proteção dos poderes públicos. (Brasil, 1967) 
No que se refere à educação, continuava a ser definida como direito de todos e deveria ser dada no lar e na escola, conforme o artigo 168, e deveria inspirar-se nos princípios da unidade nacional e nos ideais de liberdade e de solidariedade humana. Pela primeira vez uma constituição do país teria, em seu capítulo sobre educação, uma referência explícita à relação entre educação e unidade nacional. Também foi considerada como necessidade política, em função dos perigos e das ameaças da chamada Guerra Total que, polarizada entre os Estados Unidos e a União Soviética, superava os teatros localizados de conflito e supunha uma permanente ameaça do inimigo externo no interior da Nação, em qualquer ponto do território e em qualquer setor de atuação, abarcando todos os campos da vida da nação: econômico, social, psicossocial e científico.

Se a "Guerra Total" era indissociável do combate ao comunismo, demandando uma doutrina de segurança, os militares ficaram frente a frente com a necessidade imperiosa de diminuir a miséria, por meio do planejamento econômico capaz de levar ao desenvolvimento como arma para sustar o crescimento da subversão e, portanto, as possibilidades da chamada Guerra Revolucionária ${ }^{26}$. Era tarefa precípua do Estado extinguir as ameaças, tanto por meio da violência perpetrada contra todos os possíveis agentes do comunismo internacional, como por todos os meios de difusão ideológica. Fazia-se imprescindível contribuir para realizar, por meio das palavras e das ideias, a operação discursiva que buscaria a homogeneidade do povo, sedimento da unidade da nação, como o grande antídoto contra as "investidas comunistas".

Embora a garantia da educação devesse permitir a disputa ideológica que impedisse às novas gerações a aproximação e o envolvimento com o chamado comunismo internacional, a outra dimensão da questão dizia respeito à superação do subdesenvolvimento na perspectiva de tornar o Brasil uma potência capitalista. Neste contexto, ao planejamento educacional por parte do Estado caberia assegurar uma geração de jovens com acesso à formação técnica, necessária para atender às necessidades dos diferentes setores econômicos, sobretudo os industriais.

\footnotetext{
${ }^{26}$ A experiência à frente do Estado brasileiro - em particular desde o primeiro governo militar que teve à frente o Gal. Humberto de Alencar Castelo Branco, ligado à ESG - tornou centrais os estudos e a reflexão sobre o planejamento do desenvolvimento, tanto para os governos militares quanto para a Escola Superior de Guerra que, a partir de 1964, não mais os abandonou. (Rocha, 2006, p. 127)
} 
Nesta perspectiva, o planejamento foi apresentado como instrumento técnico para tornar a educação funcionalmente articulada ao binômio SegurançaDesenvolvimento. Por tais razões, era preciso estender a escolaridade tornando-a obrigatória para todos, de sete a quatorze anos, e gratuita nos estabelecimentos primários oficiais, conforme se pode verificar no inciso Il do $\S 3$ o do artigo 168 (Brasil, 1967), ainda que o debate a esse respeito fosse retomado quando da elaboração das reformas educacionais do Ensino Superior e do Ensino Médio. Por sua vez, o artigo 170 definia isso de modo semelhante aos os incisos III e IV do artigo 168, da Constituição de 1946:

As empresas comerciais e industriais são obrigadas a manter, pela forma que a lei estabelecer, o ensino primário gratuito de seus empregados e dos filhos destes.

Parágrafo único. As empresas comerciais e industriais são ainda obrigadas a ministrar, em cooperação, aprendizagem aos seus trabalhadores menores. (Ibidem)

Em relação aos demais níveis de ensino, a Constituição de 1967 anunciava o espírito e as normas jurídicas que abririam caminho para a reestruturação da educação brasileira nos anos seguintes. O inciso III do $\S 3^{\circ}$ definia que:

O ensino oficial ulterior ao primário será, igualmente, gratuito para quantos, demonstrando efetivo aproveitamento, provarem faltas ou insuficiência de recursos. Sempre que possível, o Poder Público substituirá o regime de gratuidade pelo de concessão de bolsas de estudo, exigido o posterior reembolso no caso de ensino de grau superior. (Ibidem).

Em suma, o texto constitucional conduzia o atendimento privado em relação aos níveis ulteriores ao primário, tornando absolutamente claro que se tratava de substituir a gratuidade, em particular no caso do ensino superior.

Em lugar dos direitos, repetia-se na Constituição de 1967 a dimensão assistencial do Estado pelo prisma das carências sociais. Repetia-se a formulação da Constituição de 1946, revelando uma identificação entre a eficiência educacional e as condições materiais dos estudantes. Tratava-se de uma tese que atribuía o chamado fracasso escolar às condições de pobreza. $O \S 2^{\circ}$ do artigo 169 materializava essa perspectiva: "cada sistema de ensino terá, obrigatoriamente, serviços de assistência educacional que assegurem aos alunos necessitados condições de eficiência escolar". (Ibidem) Não há outra determinação educacional, 
em particular de natureza pedagógica, no que se refere aos sistemas de ensino que concorressem para a aprendizagem dos alunos. Existia, portanto, o estabelecimento de uma relação entre ações assistenciais e eficiência escolar que não tinha sido estabelecida em outras constituições brasileiras, reforçando a ideia de que os pobres são sujeitos apenas de necessidades, não de direitos.

Com relação ao financiamento, o texto constitucional não fazia referência à vinculação de recursos para a educação, assim como na Constituição de 1937. A vinculação de recursos para a educação foi um imperativo constitucional apenas em 1934 e 1946, isto é, durante governos democráticos. Vale destacar que a Emenda Constitucional de 1969 introduziu o salário-educação como fonte de financiamento ${ }^{27}$. O artigo 178 passou a vigorar com a seguinte redação:

As empresas comerciais, industriais e agrícolas são obrigadas a manter o ensino primário gratuito de seus empregados e o ensino dos filhos destes, entre os sete e os quatorze anos, ou a concorrer para aquele fim, mediante a contribuição do salário educação, na forma que a lei estabelecer. (BRASIL, 1969b)

As mudanças constitucionais fundamentaram a profunda reforma educacional realizada pelos governos militares a serviço do binômio SegurançaDesenvolvimento. Em palestra proferida na Escola Superior de Guerra, em 29 de maio de 1970, na condição de Ministro da Educação do governo do general Emilio Garrastazu Médici, Jarbas Passarinho perguntava:

[...] a educação deve ser causa ou consequência do desenvolvimento? Em outras palavras, deve a educação receber prioridade, como condição prévia para o progresso, ou em primeiro lugar se deve obter uma razoável base econômica, da qual derivariam melhores recursos para a educação? Os que defendem a última posição garantem que somente a geração de renda pode criar poupanças para investir nas escolas e na preparação e manutenção do professorado [...]. Os governos da Revolução de 64 parecem ter feito nítida tomada de posição, em favor da educação como despesa reprodutiva de investimento [...]. Insistimos em definir a Educação como investimento e não como consumo [...] (Passarinho, 1970, p.1)

Observe-se que a educação é pensada em termos da lógica estritamente econômica, isto é, aquela que prevalece nas razões do Estado ditatorial inspirado

\footnotetext{
${ }^{27}$ O salário-educação instituído em 1964, pela Lei n. 4.440, é uma contribuição social destinada ao financiamento da educação. Campo de inúmeras modificações desde sua criação, ele segue presente normatizado pelo Decreto no 6.003 , de 28 de dezembro de 2006.
} 
pela doutrina militar da Escola Superior de Guerra (ESG), voltado à promoção do desenvolvimento do capitalismo como condição da Segurança Nacional e, inversamente, garantir a Segurança como condição do Desenvolvimento. Com essa lógica de pensamento, o Ministro apontava responsabilidades e compromissos:

[...] do Governo, que lhe deve dar tratamento prioritário nas despesas orçamentárias, não fazendo incidir cortes no seu orçamento, em proveito de prioridades melhores, de investimento; administradores da Educação e dos docentes, que devem obter o máximo de rendimento na aplicação dos meios; dos alunos, que devem corresponder ao privilégio de serem usuários da aplicação prioritária das escassas poupanças nacionais. (Ibidem)

Em vez de direitos, privilégios, este era o caráter instrumental atribuído à educação no contexto da modernização capitalista. 


\section{2 - A Nação em Conflito}

\section{1 - O público e o privado na educação}

Evidencia-se, nos recenseamentos gerais de 1940, 1950, 1960 e 1970, uma expansão da escolaridade no Brasil, indo ao encontro das expectativas de ascensão social das classes médias e as classes populares urbanas, como parte de um rápido processo de mudança social no âmbito do processo de urbanização.

É plausível considerar que os projetos de vida se voltaram para a consecução de mobilidade social, mesmo pequena, e que a educação é o campo mais privilegiado, porque seria a principal condição para aumentar as possibilidades individuais de concorrer no mercado de trabalho, com reais possibilidades de integrar os setores mais dinâmicos da economia. Por parte do Estado, significava atender a algumas das reivindicações relativas ao setor da educação, ao mesmo tempo em que atendia às demandas da internacionalização do mercado.

Em grande parte, por isso, os acordos entre o Ministério da Educação (MEC) e a United States Agency for International Development (USAID) estabelecidos entre 1964 e 1968 envolveram todos os campos da educação que deveriam se constituir em objeto de planejamento de Estado, deslocando a soberania do país, no que se refere a essa área estratégica, para uma agência norte-americana. Os acordos, MEC-USAID previam: assessoria para modernização da administração universitária; assessoria no planejamento do ensino superior; assessoria aos conselhos e secretarias estaduais de educação para análise do Ensino Secundário; planejamento do Ensino Secundário e serviços consultivos; convênio para criação de um centro de treinamento educacional; acordo de planejamento da Educação Primária; assessoria para expansão e aperfeiçoamento do quadro de professores de Ensino Médio no Brasil; evolução vocacional e treinamento rural; cooperação técnica para publicações técnicas, científicas e educacionais. (Alves, 1968).

Tratava-se de uma conciliação com o imperialismo capitalista em que a burguesia brasileira associada ao capital internacional adaptou os vários campos da vida do Brasil a um modelo de capitalismo em sintonia com o alinhamento com os 
Estados Unidos, no contexto das relações mundiais de poder. A explicitação do papel instrumental a ser desempenhado pela educação, refinando o seu deslocamento social do campo dos direitos para o das necessidades econômicas, surgiu de forma cada vez mais acentuada nos documentos produzidos pelos governos da Ditadura, em particular no governo Médici. Na introdução do Relatório Geral do Grupo de Trabalho Para a Reforma Universitária lê-se:

Se a Universidade há de realizar-se a partir de uma vontade e de um originário de seu próprio ser, ela não constitui universo encerrado em si mesmo, capaz de se reformar por suas próprias forças. Como organização social do saber, depende da comunidade que a instituiu, do Estado que assegura sua existência legal e a provê de recursos necessários a sua tarefa. A Universidade não pode ser a única instância decisória de sua inserção na sociedade. O acesso ao Ensino Superior, o uso das habilitações profissionais por ele conferidas e o saber e a cultura que a Universidade produz, concernem ao conjunto de toda a sociedade, à totalidade das instituições organizadas nos planos econômico, social e cultural e ao próprio Estado. Ainda, em sua condição de verdadeiro "poder espiritual", a Universidade só poderá exercer com eficácia essa "magistratura de espírito" articulando-se, num sistema de influências recíprocas, com todos os outros poderes da cultura, incluindo também o Estado.

[...] A nação se encontra seriamente atenta para o fato de que o Ensino Superior é investimento prioritário pela sua alta rentabilidade econômica, em longo prazo, e valorização dos recursos humanos. (Brasil, Ministério da Educação, 1968, p. 16-7)

A expressa indicação da qualificação do trabalho, no âmbito do Ensino Superior como incremento econômico, é coerente com as prospecções feitas em relação ao planejamento do desenvolvimento capitalista pelo Estado brasileiro. A legitimidade desta orientação foi dada, uma vez mais, pela nação, a "pátria grande".

Se esse crescimento equilibrado do sistema de ensino, em seus vários níveis, que concilia da melhor forma possível direito e necessidades, atendendo a uma inspiração ético-política genuinamente democrática, só esse crescimento, dizia-se, pode, de resto, responder adequadamente aos problemas postos pelo mercado de trabalho, particularmente o dos "excedentes" profissionais egressos de várias carreiras superiores. De fato, todo indivíduo que segue um curso completo de segundo grau, ou pelo menos que faz integralmente o seu curso primário, tem oportunidade de desenvolver-se, de ingressar na civilização, no sistema de produção e de distribuição do País, começando a contar como produtor e consumidor no mercado e contribuindo, graças a isso, para a própria expansão deste. (Ibidem, p. 48) 
Observe-se que, embora a referência à conciliação entre direitos e necessidades tenha prevalecido, permaneceu a perspectiva de garantia da educação primária e de segundo grau como condição para que os indivíduos se situassem socialmente em relação ao mercado, isto é, na condição de consumidores e/ou produtores. Neste caso, a necessidade se opunha à liberdade, pois no plano discursivo o sujeito aparecia subtraído da condição de cidadão. Esta ambiguidade discursiva foi sustentada pela ideia de Nação, o que nos faz lembrar de algumas das considerações de Renan:

Expulsamos da política as abstrações metafísicas e teológicas. Feito isso, o que resta? Resta o homem, com seus desejos e necessidades. Os senhores me dirão que a secessão e, em longo prazo, o esfacelamento das nações serão as consequências de um sistema que põe esses velhos organismos à mercê de vontades muitas vezes pouco esclarecidas. É claro que em tal espécie de assunto nenhum princípio deve ser levado ao extremo. As verdades dessa ordem só são explicáveis em conjunto e de modo muito geral. As vontades humanas mudam; mas o que não muda sobre a terra? As nações não são algo de eterno. Tiveram um começo, terão um fim. A confederação europeia provavelmente virá substituí-las. Mas esta não é a lei do século em que vivemos [...].

Por meio de suas faculdades diversas e frequentemente opostas, as nações servem à obra comum da civilização; todas contribuem com uma nota ao grande concerto da humanidade que, em suma, é a mais alta realidade ideal que conseguimos conceber. (Renan, 1997, p. 174)

A nação adjetivada como homogênea e unida em torno do léxico e da prosperidade do mercado tornou-se a grande sustentação ideológica do Estado brasileiro, submetendo os objetivos da educação à perspectiva de tornar o Brasil uma grande potência capitalista em aliança com os Estados Unidos. Esta representação, uma vez convertida em projeto de Estado, sobredeterminou qualquer necessidade e/ou direitos dos sujeitos, ocupando o centro de uma estrutura discursiva voltada para um "universo civilizatório" nos quais se moveram os militares à frente do Estado. Para tanto era preciso, mais do que o previsto na Constituição de 1967, levar a efeito uma sistemática política de controle e de contenção social.

Não foi diferente o sentido da Reforma Universitária, na prática um instrumento para sustar as manifestações e as reivindicações estudantis de 1968 e assegurar um processo de racionalização das vagas disponíveis, operando, dessa forma, uma expansão do sistema com um mínimo de custo. A departamentalização, 
a matrícula por disciplina, a instituição do curso básico, a unificação do vestibular por região e o ingresso por classificação, a fragmentação do grau acadêmico de graduação (por exemplo, licenciaturas curtas) e a institucionalização da pósgraduação constituem-se nas medidas fundamentais. Tiveram elas caráter complementar, de tal sorte, que a departamentalização e a matrícula por disciplina permitiriam economia de professores, salas e materiais. O curso básico, por sua vez, permitiria realocar os estudantes, considerando suas escolhas, seu desempenho e a disponibilidade de vagas em cada curso. $O$ vestibular regional, que progressivamente tornou-se classificatório, iria no mesmo sentido, visando a completar as vagas das instituições em cada região. (Cunha, 1980, p. 242-4)

O teor do relatório do Grupo de Trabalho para promover a Reforma Universitária se consubstanciou na proposta de anteprojeto de lei que fixou normas de organização e funcionamento do Ensino Superior no Brasil, inspirando a elaboração da Lei 5.540, de 28 de novembro de 1968. A "racionalização, a eficiência e a produtividade tornaram-se valores absolutos" (Romanelli, 1982, p. 231), pretendendo-se com eles extirpar a dimensão político-ideológica da organização e produção das universidades, colocando-as funcionalmente organizadas para reduzir gastos, liberando os recursos do Estado para outros investimentos, além de direcionar a formação dos jovens à docência e à pesquisa, visando a atender às necessidades e interesses do modelo de desenvolvimento dirigido pelos militares.

A redução das funções dos dirigentes e do papel dos órgãos internos das universidades a uma dimensão tecnocrática - estruturada a partir da fragmentação, da negação da participação e do livre debate -, ao mesmo tempo em que era apresentada como imprescindível, tornava-se um dos instrumentos de crítica e esvaziamento da autonomia, isto é, da capacidade da Universidade de interferir e de controlar sua produção (Ibidem, p. 232.). Para efetivar a reforma, foi tomado como apoio a edição do Decreto-lei 477, de 26 de fevereiro de 1969, instrumento corporificado do Ato Institucional no 5 na Universidade ${ }^{28}$, que permitia suspender e

\footnotetext{
${ }^{28}$ O Ato Institucional $\mathrm{n}^{\circ}$ 5, (Al-5) foi promulgado em 13 de dezembro de 1968, durante o governo do general Costa e Silva, e vigorou até dezembro de 1978. Previa, entre outras determinações, que o Presidente da República poderia decretar o recesso do Congresso Nacional, das Assembleias Legislativas e das Câmaras de Vereadores por Ato Complementar, em estado de sítio ou fora dele, só voltando a funcionar por sua decisão. O Presidente da República poderia decretar a intervenção nos Estados e Municípios, sem as limitações previstas na Constituição; poderia decretar o estado de sítio e prorrogá-lo, bem como a suspensão dos direitos políticos. O Presidente poderia suspender a garantia de habeas corpus nos casos de caracterização, pelo Estado, de crimes políticos contra a
} 
desligar os estudantes considerados subversivos e ameaçadores à Segurança Nacional.

O contexto de adaptar e subordinar a educação à lógica do mercado se completaria com a Reforma do Ensino Médio. O Relatório Geral do Grupo de Trabalho Para a Reforma Universitária, constatando que a vocação do Curso Secundário era a de preparar os estudantes para a Universidade, indicava a necessidade de que no segundo grau os jovens tivessem acesso à formação geral e técnica "evitando a marginalização dos que encerram a vida escolar ao nível do segundo grau" (Brasil, Ministério da Educação, 1968, p. 29) e, ao mesmo tempo, permitindo que os mais capazes chegassem à Universidade.

É certo que, de forma ainda mais explícita que em 1967, a perspectiva de adjetivar a sociedade como estamental era conformada a partir de argumentos que naturalizavam as diferenças e as desigualdades sociais e educacionais. Tal direcionamento foi justificado por dois aspectos característicos da experiência individual: a herança genética e o esforço pessoal. De forma ambígua, em mensagem dirigida ao Congresso Nacional em 25 de junho de 1971, Emilio Garrastazu Médici, ao apresentar a Lei 5.692, indicava que as medidas previstas deveriam democratizar o ensino de maneira a assegurar a todos o direito à Educação. Em suas próprias palavras:

Abre-se caminho destarte, para que possa qualquer do povo, na
razão de seus predicados genéticos, desenvolver a própria
personalidade e atingir, na escala social a posição que tenha jus. [...]
Concorrerão essas medidas, juntamente com outras previstas no
projeto, para romper as barreiras que ainda se opõem à plena
difusão do ensino e para que se acelere o processo tendente a
proporcionar a todos os elementos fundamentais para que, em
igualdade de condições quanto ao aprendizado inicial, possam
realizar, na construção do seu destino, as escolhas correspondentes
às suas aspirações e qualidades individuais. (Médici, 1971, p. 6)

segurança nacional, a ordem econômica e social e a economia popular. Depois da promulgação do Al-5, a censura atingiu ainda mais fortemente a imprensa. Foram expurgados 37 deputados da ARENA, depois outros 51, incluindo-se Márcio Moreira Alves e Hermano Alves. Carlos Lacerda, defensor do golpe de Estado, foi privado de seus direitos políticos. Todas as forças policiais e militares do País foram colocadas sob controle do Ministro da Guerra. O Judiciário foi fortemente atingido pela aposentadoria forçada de três ministros do Supremo Tribunal Federal, a renúncia de seu presidente e a redução de seus membros de 16 para 11 . O Al-5 promoveu a institucionalização dos mecanismos de coerção do Estado, facilitando, dessa maneira, a ação do aparato repressivo, os atentados contra as liberdades fundamentais e os direitos humanos (Skidmore, 1994, p. 166-7). 
O direito tinha alcance restrito, uma vez que era limitado pelas características biológicas articuladas às qualidades morais e intelectuais do indivíduo que influiriam diretamente no acesso ao Ensino Médio e, sobretudo, ao Ensino Superior. O discurso liberal justificava classificar e hierarquizar no âmbito político, econômico e social, de modo a que a Educação se tornasse instrumento fundamental de mudança e de progresso, conforme a visão de uma Nação brasileira como uma grande e poderosa nação democrática do futuro.

Porém, nesse período, mesmo os direitos educacionais mais elementares foram objeto de controvérsia. Todos os relatórios produzidos para o debate da reforma do Ensino Superior indicaram a necessidade de alterar a Educação Primária e o Ensino Médio. As propostas oriundas dos acordos MEC-USAID pretendiam também uma reforma da Escola Fundamental, visando superar a divisão em compartimentos entre o Primário e o Ginásio. Os relatórios Meira Mattos e do Grupo de Trabalho da Reforma Universitária apresentaram propostas diferentes, visando fortalecer a reforma do Ensino Médio, articulando-a com a reforma da Universidade.

A diferença parecia situar-se em torno das proposições que melhor atenderiam aos interesses do capitalismo brasileiro. $O$ enfoque que privilegiava a reestruturação da Escola Fundamental tinha como horizonte a qualificação do trabalhador, tendo como limite a imposição de que a mão de obra continuasse a ter um custo baixo para o capital. Além disso, os defensores da reestruturação do Ensino Médio entendiam que a profissionalização, além de atender às necessidades mais imediatas do mercado e garantir trabalho para os jovens, realizaria uma seleção, de acordo com a qual apenas os mais aptos chegariam à Universidade. (Romanelli, 1982, p. 234-5). Nestas circunstâncias, a origem de classe dos jovens dificilmente seria superada, induzindo à perpetuação das desigualdades sociais. A Lei resultou de uma síntese das duas abordagens, como se pode constatar nas afirmações do Ministro da Educação e Cultura Jarbas Passarinho, na Exposição de Motivos que apresentou a Lei. Dizia ele:

Assim desde o início, repeliu-se com muita firmeza a tese de primeiro desenvolver para depois educar, que a quase nada conduziria. Enquanto, por esta forma, o desenvolvimento cedo se deteria ante a ausência de um sistema educacional que lhe servisse de suporte, o pouco a ser conseguido teria de fazer-se com o sacrifício do seu próprio destinatário. Mas daí tampouco se enveredou pela falácia oposta de uma Educação anterior ao desenvolvimento como "um 
moinho a girar no vazio". O equilíbrio estaria, portanto, em promover a cada momento, em quantidade e qualidade, uma escolarização compatível com o grau alcançado de progresso material, e viceversa, de tal modo que a mais Educação sempre viesse a corresponder mais desenvolvimento e, reciprocamente, do maior desenvolvimento sempre resultasse mais e melhor educação [...]

Agora, V. Exa. não proporá ao Congresso Nacional apenas mais uma reforma, mas a própria reforma que implica abandonar o ensino verbalístico e academizante para partir vigorosamente para um sistema educativo de $1^{\circ}$ e $2^{\circ}$ graus, voltado para as necessidades do desenvolvimento. $\mathrm{E}$ como a educação pré-determina 0 desenvolvimento, o abandono do ensino meramente propedêutico, pela adoção de um processo que valorize progressivamente o estudante, dando terminalidade à escola de segundo grau, preparando os técnicos de nível médio de que tem fome a empresa privada como a pública, significa uma revolução, no sentido sociológico do termo: atinge as raízes do processo, e em curto prazo. Em uma palavra é o que V.Exa. preconiza: a Revolução pela Educação. (Passarinho, 1971, p. 7)

Pretendeu-se a criação de uma escola única voltada para o trabalho, ainda que com diferenciações entre o $1^{\circ}$ e o $2^{\circ}$ graus. No primeiro caso, concebeu-se a escola de 8 anos, integrando o antigo primário e o ginásio, devendo assegurar, além da chamada formação geral, a sondagem vocacional e a iniciação para o trabalho, de tal modo que, caso necessário, o estudante pudesse se transformar em força de trabalho. No segundo caso, tratava-se de, além da formação geral, garantir habilitação profissional no grau médio, em consonância com as necessidades do mercado de trabalho local, regional ou nacional. Cativa das determinações afetas às necessidades econômicas, a Lei concretizou a terminalidade em cada um dos graus de ensino, sobrepondo os interesses do capital à vontade e ao direito do sujeito, minimizando qualquer anseio de mobilidade social. ${ }^{29}$

O $1^{\circ}$ artigo da Lei indicava os objetivos do ensino de $1^{\circ}$ e $2^{\circ}$ graus: proporcionar ao educando a formação necessária ao desenvolvimento de suas potencialidades como elemento de autorrealização, qualificação para o trabalho e preparo para o exercício consciente da cidadania. Porém, note-se que, mesmo os objetivos se referindo ao sujeito, a soberania e a liberdade eram capturados para o

\footnotetext{
${ }^{29}$ A Lei 5.692, de 11 de agosto de 1971, previu que o ensino de $1^{\circ}$ grau, destinado à formação da criança e do adolescente, seria obrigatório, teria duração de oito anos letivos, envolvendo 720 horas anuais de atividade. Para ingressar no $1^{\circ}$ grau a criança deveria ter a idade mínima de sete anos. $O$ ensino de $2^{\circ}$ grau, voltado à formação integral do adolescente, deveria ter duração de três ou quatro séries anuais, com, respectivamente, 2.220 e 2.900 horas anuais de efetivo trabalho escolar.
} 
controle do Estado, fonte da racionalização política capaz de encetar o desenvolvimento.

A proposição, entretanto, encontrou fortes limites para sua realização. As contradições do próprio capitalismo transformariam o que estava sendo apresentado em um problema. Na visão costumeira difundida pelos militares, a qualificação profissional resultaria no acesso a empregos com salários mais elevados e, por conseguinte, em melhoria das condições de vida e, não raro, de ascensão social. Ocorre que para o estabelecimento das relações entre emprego e escolaridade concorriam vários fatores: elevação da qualificação técnica da parcela trabalhadora, oferta das ocupações, sobretudo, oferta de pessoas com qualificação profissional, e determinado nível de escolaridade.

No mercado de trabalho, se o volume de pessoas com uma mesma qualificação fosse maior que o número de ocupações, o mais provável era que ocorresse o rebaixamento das ofertas salariais ou o reaproveitamento de profissionais de uma determinada área em postos de trabalho que exigissem menor qualificação, promovendo, desta forma, o barateamento do custo da mão de obra. $E$ no caso da ampliação de escolaridade a questão seria similar, pois os requisitos educacionais seriam elevados em ocupações para as quais as exigências de escolarização fossem menores, gerando um setor social que, sendo menos escolarizado, se tornaria passível de maior exclusão e, portanto, de integração a um exército de reserva necessário e funcional ao capitalismo. (Cunha, 1980, p. 264-265)

Podemos dizer, portanto, que a relação entre qualificação profissional e emprego dependia da dinâmica do sistema capitalista em cada conjuntura particular e das ações do Estado em situações específicas, fazendo prevalecer necessidades e interesses do capital ou criando situações econômicas capazes de promover também os direitos dos trabalhadores. Desta maneira, o esforço de racionalização e planejamento do Estado brasileiro, visando à qualificação profissional de longo prazo, não se mostrava compatível com a natureza das demandas imediatas e mutáveis da economia de mercado. (Cury et al., 1982).

A viabilidade de uma perspectiva instrumental em relação à educação teve inúmeros limites para ser implantada no Brasil. A partir de 1974 se intensificaram os questionamentos em relação à Lei 5.692/71, fundamentalmente em relação à 
obrigatoriedade da profissionalização no $2^{\circ}$ grau e, quanto à universalidade, da preparação para um trabalho específico. A pretensa habilitação profissional diluiu-se em educação para o trabalho, em consonância com as proposições do Conselho Federal de Educação quanto à atividade para habilitação profissional e a necessidade de regime de cooperação com as empresas para formação profissional, o que foi estabelecido pela Lei 6.297/75, oferecendo-se incentivos fiscais. A partir de 1976 o país estruturaria o Sistema Nacional de Formação de Mão de Obra (SNFMO). (Ibidem)

Quando a Constituinte teve início, a crítica às razões do Estado movida pelos Objetivos Nacionais de Segurança e Desenvolvimento já tinham capilaridade na sociedade brasileira. O capital, sem as limitações do Estado autoritário, podia se movimentar livremente em busca de alianças voltadas à materialização de seus interesses imediatos. A disputa pelos fundos públicos tomou forma, e os discursos e propostas dos setores privatistas da educação foram apresentados na batalha conceitual e política com os segmentos da sociedade que, representados por movimentos e entidades, se organizavam em torno de seus direitos.

Esgarçavam-se os véus que encobriam as contradições da "modernização conservadora" tornando-as transparentes à Nação.

\section{2 - Os fundos públicos em questão}

O debate sobre os fundos públicos teve início antes mesmo da instalação da constituinte, em função das propostas presentes no relatório Afonso Arinos, divulgado pelo Presidente José Sarney, que apresentava 0 anteprojeto constitucional elaborado pela Comissão Provisória de Estudos Constitucionais, com um capítulo de dez artigos dedicados à Educação (Brasil, 1986, p. 52-3). O projeto, publicado no Diário Oficial de 26 de setembro de 1986, a quase dois meses das eleições presidenciais, teve uma apresentação do então Presidente da República, na qual suas ideias sobre a natureza da transição foram reafirmadas. Referia-se ao papel da Constituinte no contexto da transição negociada. O processo constituinte não deveria ensejar rupturas com as instituições herdadas do regime militar. 
A apresentação, ao registrar as palavras do Presidente quando da instalação da Comissão, no dia 3 de setembro de 1985, afirmava:

Sem uma ruptura do Estado - e devemos dar graças a Deus por tê-la evitado - não nos cabia outra saída que a de convocar a Assembleia Nacional Constituinte com a solidariedade do Congresso Nacional.

O que faz a autenticidade das Constituições não é a forma de convocar-se o Colégio Constituinte: é a submissão do texto fundamental à vontade e à fé dos cidadãos. Essa vontade e essa fé, para que se manifestem, reclamam discussão, como reclamam recolher e codificar a reflexão que ela provoque.

Encontram-se aqui alguns dos mais ilustres e honrados cidadãos deste País. Sou responsável pela escolha deste grupo, e fico feliz em Ihes dizer que não foi fácil a decisão. O Brasil dispõe de milhares de homens e mulheres capazes de interpretar o sentimento do povo, e ter-se à razão do povo, e de servir com alegria ao Povo. (Brasil, 1986, p. 2)

O texto faz alusão à autenticidade das Constituições, mas não à sua legitimidade, isto é, às condições de sua convocação, da eleição de seus membros e de sua função, o que contribui para definição de suas condições de soberania e alcance e das transformações institucionais.

A autenticidade resultaria não do processo de representação em condições de eleições livres, mas da capacidade do texto constitucional em exprimir "a vontade" e "a fé" do cidadão. A prática sugerida pelo texto guarda relação com o pensamento dominante nas Forças Armadas e sua herança, segundo a qual caberia às elites a interpretação dos anseios e necessidades do povo a serem consubstanciados em Objetivos Nacionais. No seu conjunto, essas ideias apontam para uma noção instrumental de uma democracia que restringia a soberania da sociedade e ampliava os poderes do Estado. Era um discurso que se propunha como próprio de uma conjuntura de transição, uma transição sem rupturas com nenhuma preocupação com a dimensão republicana, com a dimensão cívica da democracia:

Se quisermos uma grande Nação, teremos que ser uma grande democracia. Mas só seremos uma grande democracia no dia em que tivermos um pacto que, acima dos homens, das facções e dos partidos, faça de nossa estrutura política a convivência pacífica de todos os brasileiros, regidos por instituições livres, estáveis, respeitáveis e duradouras. (Ibidem, p. 1) 
Tal pacto, a ser estabelecido "acima dos homens, das facções e dos partidos", se deslocou da experiência democrática, na qual os partidos e organizações da sociedade civil devem expressar seus programas, posições e propostas como condição do debate, da negociação e da decisão. O deslizamento no interior do discurso oculta precisamente as condições de estabelecimento do pacto que se antepõe ao processo democrático antes mesmo das eleições que ocorreriam em novembro de 1986. Assim, desta feita, sem se contrapor à soberania do povo, a apresentação do Anteprojeto Constitucional elaborado pela Comissão é concluída com mais uma citação do discurso proferido quando de sua instalação:

A Comissão não substituirá o Congresso nem substituirá o povo. Será, na verdade, uma ponte de alguns meses entre a gente brasileira e os representantes que ela elegerá. Servirá como uma área de discussão livre e informal das razões nacionais, submetendo ao debate público teses básicas quanto ao Estado, à sociedade e à nação. (Ibidem, p. 1)

A Comissão materializaria uma primeira tentativa de mediação entre o Estado e as diferentes representações das classes sociais, do movimento sindical e dos movimentos sociais que definem novas arenas sociais e tendem mais a falar contra o regime autoritário do que definir novas condições. Deixam claros seus interesses, antecipando o pacto ao qual o Presidente fez referência. Para o Estado, tratava-se de manter controle sobre os diferentes segmentos sociais que se mobilizavam para lutar em favor de suas necessidades e reivindicações. Entretanto, se perdermos certa ilusão de que não há competição e nos propusermos a identificá-la, talvez o caminho mais promissor seja apreender a definição dos objetivos que estão em jogo. No caso dos donos do poder, tratava-se, no plano discursivo e na prática política, de se antecipar buscando subsumir e amarrar as reivindicações e proposições ao Estado, à Sociedade e à Nação, em uma situação caracterizada pela imunidade do Executivo, mantendo difuso o fato de que havia transformações absolutamente fundamentais, como o crescimento econômico e a questão da redistribuição da riqueza, além de um tema posto em pauta desde a II Guerra Mundial: a premência de repensar nosso sistema de relações internacionais com as economias atrasadas e com as desenvolvidas.

Apesar do paradoxo do sucesso do regime autoritário ter sido alcançado por contar com uma minoria democrática de atores sociais, a grande maioria não era 
democrática, antes, antiautoritária. Sem ter como ponto diferenciador o conceito de República correspondendo aos problemas mais urgentes, os quais os dirigentes do País não conseguiam enfrentar, o controle do Estado continuava a ser bastante intenso. Sem o resgate da noção de República, se acentuaram os direitos e experiências de privatização, retomando a diferença clássica entre as questões privadas e as questões públicas. Nestas circunstâncias, é característico que uma das questões tidas como potencialmente conflitivas tenha sido a relativa à natureza da distribuição dos recursos públicos para assegurar a oferta de Educação. Para examinar como o Anteprojeto Constitucional tratou desse problema, é preciso referirse, em primeiro lugar, à abordagem relativa a este direito no artigo 384 :

A Educação, direito de todos e dever do Estado, visa ao pleno
desenvolvimento da pessoa e à formação do cidadão, para o
aprimoramento da democracia, dos direitos humanos, da convivência
solidária a serviço de uma sociedade justa e livre. (Ibidem, p. 52 )

A Educação, tal qual nas Constituições de 1934, 1946, 1967 e 1969, é apontada como direito de todos os cidadãos e dever do Estado. No entanto, diferentemente de todas as outras, incluindo-se a de 1937, não há no texto proposto referência às responsabilidades da família no artigo inicial. Tal referência só apareceria no artigo 386, uma vez mais sustentando a dubiedade da definição: "A Educação é dever dos pais e, desde o nível pré-escolar, do Estado". Caberia ao Estado financiar a Educação nacional, não necessariamente pública, razão pela qual se prevê a vinculação de recursos no artigo 388 , relativo ao financiamento da Educação nacional:

A União aplicará anualmente não menos de treze por cento, os Estados, o Distrito Federal e os Municípios no mínimo vinte e cinco por cento, do que lhes couber do produto da arrecadação dos respectivos impostos na manutenção e desenvolvimento do ensino; realizado em obediência às diretrizes do artigo 385.

§1 - A repartição de recursos públicos para a educação assegurará prioritariamente 0 atendimento das necessidades do ensino obrigatório.

$\S 2^{\circ}$ - Lei complementar determinará plurianualmente o percentual de recursos da União, do Distrito Federal e dos Estados aplicados a este fim.

$\S 3^{\circ}$ - Os Municípios aplicarão não menos de vinte e cinco por cento de seus impostos no ensino obrigatório e pré-escolar. (Ibidem, p. 52) 
A vinculação se justificava no anteprojeto em função da manifesta responsabilidade do Estado e da perspectiva de gratuidade do acesso à educação prevista no artigo 390:

O acesso ao processo educacional é assegurado:

I - pela gratuidade do ensino público em todos os níveis;

II - pela adoção de um sistema de admissão nos estabelecimentos de ensino público que, na forma da lei, confira a candidatos economicamente carentes, desde que habilitados, prioridade de acesso até o limite de cinquenta por cento das vagas;

III - pela expansão desta gratuidade, mediante sistema de bolsas de estudos, sempre dentro da prova de carência econômica de seus beneficiários;

IV - pelo auxílio suplementar ao estudante para alimentação, transporte e vestuário, caso a simples gratuidade de ensino não permita, comprovadamente, que venha a continuar seu aprendizado;

$\mathrm{V}$ - pela manutenção da obrigatoriedade de as empresas comerciais, industriais e agrícolas garantirem ensino gratuito para os seus empregados, e filhos destes, entre os seis e dezesseis anos de idade, ou concorrer para esse fim, mediante a contribuição do salário educacional na forma estabelecida pela lei;

VI - pela criação complementar à rede municipal de escolas de promoção popular, capazes de assegurar efetivas condições de acesso. (Ibidem, p. 52)

Como se pode verificar, o texto assegura a gratuidade em todos os níveis da educação, como nas Constituições elaboradas desde 1946, mas não o faz indicando qual a dimensão da oferta pública. Quando da elaboração de cada uma das constituições, as tensões envolvidas na garantia de direitos, no contexto das conjunturas específicas, tiveram relação com a apropriação social dos fundos públicos em face dos problemas e necessidades sociais acumulados, razão pela qual o planejamento das políticas, ações e investimentos tornou-se um desafio. Observe-se que o anteprojeto prevê a oferta de gratuidade aos chamados "candidatos carentes" e projeta a expansão da gratuidade, também voltada aos mesmos setores, por meio de um sistema de bolsas de estudos. Além do amparo, por meio do salário-educação, às empresas comerciais, industriais e agrícolas para que garantam ensino gratuito para os seus empregados e filhos. A formulação, nesse caso, assemelha-se às definições das Constituições de 1946, 1967 e, particularmente, à Constituição de 1969. (Brasil, 1946, art. 166 a 175; Idem, 1967, art. 168 a 170; e Idem, 1969, art. 176 a 178) 
A expansão da oferta é anunciada também pela criação de uma rede complementar às redes municipais, de caráter inespecífico, voltada a assegurar efetivas condições de acesso à coletividade. Observe-se que, ao tratar da oferta de vagas, o texto deixa de referir-se aos cidadãos e se refere às chamadas pessoas carentes. $O$ atendimento deixa de ser justificado pelo direito enquanto condição que, entre outras, define a cidadania e se associa ao que Ihes falta em termos sociais, isto é, o aporte de vagas públicas, passando a referir-se à noção de privação resultante da condição socioeconômica dos indivíduos. Significa dizer que a oferta de vagas passou a ser entendida como ação reparadora para aqueles que não lograram outra condição social.

Nas letras da Lei, retomava-se a primazia do privado em detrimento do público, sob a coordenação do Estado, posto que a ampliação do acesso à Educação deveria ocorrer por meio da transferência de recursos. Merece destaque o fato de não se identificar no texto qualquer referência ao planejamento dos poderes públicos visando a ampliar a participação do Estado na oferta educacional, seja por meio da Lei de Diretrizes e Bases e/ou pela elaboração, aprovação e consecução do Plano Nacional de Educação.

Outra dimensão importante é a ausência de referências ao currículo quando se trata dos princípios educacionais nos âmbitos público e privado. Note-se que as diretrizes se referem, entre outros aspectos, ao pluralismo de ideias em instituições públicas e privadas, à adequação aos valores e às condições regionais e locais e à superação da marginalidade social e econômica. O artigo 394, do anteprojeto, define que os direitos, deveres e garantias do cidadão constituirão matéria curricular obrigatória em todos os níveis de educação, entretanto não há referências no documento ao direito ao conhecimento por meio da instituição escolar.

No rastro das determinações da Lei 5.692/71, o caput do artigo 387 define: "o ensino é obrigatório para todos, dos seis aos dezesseis anos, e incluirá a habilitação para o exercício de uma atividade profissional." (Brasil, 1986, p. 52). Por seu turno, a defesa dos interesses de mercado se completa com os critérios estabelecidos para a transferência de recursos públicos ao ensino privado:

[...] dentro de quantitativos previamente estabelecidos, e obedecendo a processo classificatório tendo em vista:

I - a contribuição inovadora da instituição para o ensino e pesquisa; 
II - o suprimento de deficiências qualitativas ou quantitativas do ensino público;

III - a participação de representantes da comunidade nas decisões da instituição beneficiada;

IV - o interesse comunitário da sua atividade.

Parágrafo Único - Têm prioridade na atribuição desses recursos as instituições de interesse social, reconhecidas pelos poderes públicos, e capazes de compensar, progressivamente, com recursos alternativos, o auxílio recebido pelo Estado. (Ibidem, p. 52-3)

Com efeito, os incisos indicados atendiam à reivindicação do empresariado no sentido de direcionar o fluxo de estudantes de renda mais elevada para as instituições de Ensino Superior, particularmente para as universidades católicas, contemplando-os com bolsas de estudo. (Cunha, 2012, p. 428). Quanto ao artigo 30 das Disposições Constitucionais Gerais e Transitórias do anteprojeto, por sua vez, abolia o vestibular e conferia às universidades o direito de elaborar suas normas próprias de admissão a partir de Lei que fixaria critérios mínimos de acesso ao Ensino Superior ${ }^{30}$.

Não obstante, no preâmbulo do anteprojeto Afonso Arinos, indica-se como um dos compromissos declarados para uma vida digna para todos os brasileiros 0 direito da criança e do adulto à Educação, à formação profissional e à cultura. Podese verificar que o acesso por meio da gratuidade tem como referência, no anteprojeto, a transferência de recursos públicos ao ensino privado, comprometendo o direito à Educação ao deslocá-lo para a esfera da gestão e da dinâmica dos interesses das instituições privadas.

No contexto da finalização dos trabalhos da Comissão Afonso Arinos, um importante documento foi divulgado em 05 de setembro de 1986 a todo o país. Trata-se da Carta de Goiânia, elaborada na IV Conferência Brasileira de Educação.

As Conferências Brasileiras de Educação (CBEs) tiveram início em 1980. ${ }^{31}$ Foram promovidas por três entidades nacionais: Associação Nacional de Pós-

\footnotetext{
30 "Art. 30 - È abolido o atual sistema de concurso de vestibular. A lei fixará critérios mínimos para acesso ao ensino superior e respeitará a autonomia das universidades para estabelecer suas próprias normas de admissão."

"Parágrafo único - Enquanto não for regulada pela lei competente, o regime de admissão será disciplinado pelas universidades, no que Ihes diga respeito, e pelo Ministério da Educação, no que se refira aos demais estabelecimentos de ensino superior." (Ibidem, p. 60).

${ }^{31}$ Foram realizadas cinco Conferências Brasileiras de Educação (CBEs), na década de 80, sendo: I CBE, 1980 - São Paulo (PUC - 1.400 participantes); II CBE, 1982 - Belo Horizonte (UFMG - 2.000
} 
Graduação em Educação (ANPEd), criada em 1976 e que congrega programas de pós-graduação stricto sensu em educação, professores e estudantes vinculados a estes programas e demais pesquisadores da área; o Centro de Estudos Educação e Sociedade (CEDES), criado na Universidade Estadual de Campinas em 1978; e a Associação Nacional de Educação (ANDE), fundada em 1979 e constituída por professores e especialistas que atuavam no ensino superior e no ensino de $1^{\circ}$ e $2^{\circ}$ graus e pesquisadores de temas educacionais. As Conferências também tiveram na comissão organizadora a presença do Centro de Estudos de Cultura Contemporânea (CEDEC).

As Conferências contaram com grande apoio das universidades onde se realizaram e, embora tenham recebido apoio financeiro de instituições governamentais, como o Fundo Nacional de Desenvolvimento da Educação (FNDE), a Coordenação de Aperfeiçoamento do Pessoal de Nível Superior (CAPES), o Conselho Nacional de Desenvolvimento Científico e Tecnológico (CNPq), a Financiadora de Estudos e Projetos (FINEP) e de bancos governamentais, não houve interferência na programação nem na indicação dos nomes dos palestrantes, nem imposição das opiniões do governo em relação aos temas tratados.

Dentre os documentos finais apresentados pelas Conferências, a Carta de Goiânia (Anexo B) revestiu-se de particular importância, seja porque expressou o amadurecimento do debate realizado nas Conferências anteriores, seja em função da conjuntura política de convocação da Assembleia Nacional Constituinte, que tornava necessário um posicionamento sobre as principais questões em relação à educação no país. Naquela conjuntura histórica, a Carta tornou-se o contraponto mais importante da sociedade civil ao anteprojeto da Comissão Afonso Arinos e às políticas nele defendidas: ao mesmo tempo em que expressava o posicionamento de entidades, organizações e pesquisadores, apresentava à sociedade a urgência de tornar a educação um direito para a maioria da população do país.

Os profissionais da Educação declaram-se cientes de suas responsabilidades na construção de uma Nação democrática, onde os cidadãos possam exercer plenamente seus direitos, sem discriminação de qualquer espécie. Estão por isso, empenhados em debater, analisar e fazer denúncias dos problemas e impasses da 
educação brasileira e, ao mesmo tempo, em colocar sua capacidade profissional e sua vontade política para a superação dos obstáculos que impedem a universalização do ensino público para todo o povo brasileiro.

A IV Conferência Brasileira de Educação, ao propor princípios básicos a serem inscritos na Constituição, tem presente que o País enfrenta graves problemas sociais e econômicos, de natureza estrutural, que entravam a efetiva democratização do conjunto da sociedade. Tem presente, também, que o não enfrentamento urgente de tais problemas acarretará o comprometimento da viabilização das políticas sociais, especialmente da política educacional.

De fato, dados divulgados pelo próprio Governo Federal mostram que cerca de $60 \%$ dos brasileiros encontram-se em estado de extrema pobreza material, em contraste com uma minoria de grupos privilegiados que detém o usufruto privado da riqueza que é social. Isso significa que as aspirações da coletividade pela democracia econômica, social e política são obstaculizadas por uma organização social e política injusta e, em decorrência, por políticas governamentais incapazes de promover a justiça social. Persiste uma política econômica e particularmente salarial, marcada pela distribuição desigual da renda, cujas expressões são: a questão agrária e a violência social contra os trabalhadores rurais; o enorme endividamento externo: a dívida pública; o precário atendimento às necessidades de escolarização da população e de outras políticas sociais como a saúde, a assistência e previdência social. [...]

- mais de $50 \%$ de alunos repetentes ou excluídos ao longo da $1^{\text {a }}$ série do ensino de $1^{\circ}$ grau;

- cerca de $30 \%$ de crianças e jovens na faixa dos 7 aos 14 anos fora da escola;

- 30\% de analfabetos adultos e numeroso contingente de jovens e adultos sem acesso à escolarização básica;

- 22\% de professores leigos;

- precária formação e aperfeiçoamento profissional de professores em todo o País;

- salários aviltados em todos os graus de ensino. (Anexo B)

A Carta de Goiânia apresenta os educadores, em termos profissionais e políticos, como sujeitos da construção de uma nação democrática e em movimento. Dois elementos marcam o discurso: o primeiro reconhece a nação dividida em função das profundas desigualdades sociais e pela apropriação da riqueza social por um número pequeno de privilegiados; o segundo identifica a democracia com a garantia a todos os cidadãos de direitos, entre os quais a Educação. O eixo a partir do qual foram formuladas todas as propostas é a universalização do ensino público de qualidade para todo o povo brasileiro. 
A Carta prossegue referindo-se ao manifesto aprovado na III Conferência Brasileira de Educação, na qual os educadores reunidos tornavam públicas as expectativas de que houvesse mudanças no quadro de injustiças sociais, tanto em função da luta pela democratização, como pela realização de eleições para os governos estaduais. Todavia, depois de dois anos a Carta denunciava a incapacidade do sistema político de assegurar diretrizes educacionais capazes de atender aos interesses da maioria da população. O texto contrapõe tais diretrizes aos programas criados para promover visibilidade política e favorecer interesses de grupos. Assim, reconhece as referidas medidas como descontínuas e desconectadas de um Plano Global: o Dia D da Educação, Educação Para Todos, Programa Nacional do Livro Didático, Projeto Educar, Projeto Nova Universidade, Projeto das 200 Escolas Técnicas, além das chamadas Comissões de Alto Nível. A crítica se estende aos governos estaduais, acrescendo-se a utilização da estrutura e dos recursos da Educação para outros programas, como assistência, saúde e treinamento profissional.

A Carta destacava ainda que as verbas públicas estavam sendo destinadas aos projetos de impacto político e às instituições privadas, não atendendo às prioridades do país. Alertava para a tendência de agravamento da situação em face das ações dos grupos privatistas visando a assegurar seus próprios interesses. Assim, antevendo os embates no âmbito do processo constituinte com os setores privatistas, a IV Conferência Brasileira de Educação reivindicava que a Carta Constitucional consagrasse "os princípios de direito de todos os cidadãos brasileiros à Educação, em todos os graus de ensino e de dever do Estado em promover os meios para garanti-la".

No que diz respeito aos itens 1 e 2 , eles se referem à igualdade de direitos a ser assegurada com recursos públicos pelo Estado, tendo a lei como instrumento de garantia de tais princípios. O ponto 1 indica que "a educação escolar é um direito de todos os brasileiros e será gratuita e laica nos estabelecimentos públicos em todos os níveis de ensino." O ponto dois defende que:

Todos os brasileiros têm direito à educação pública básica comum, gratuita e de igual qualidade, independentemente de sexo, cor, idade, confissão religiosa e filiação política, assim como da classe social ou da riqueza regional, estadual ou local. (Anexo B) 
Os itens referidos colocam o direito acima das diferenças de qualquer espécie e se distinguem do parágrafo único do artigo 384 do anteprojeto Afonso Arinos, em função da ênfase no direito à educação pública de qualidade. Ainda que no caput do artigo 384 seja feita a indicação de que a Educação é direito de todos e dever do Estado, como já apontamos anteriormente, no parágrafo único ela é apresentada como inseparável dos imperativos do desenvolvimento, assim como dos princípios de igualdade, democracia e pluralismo cultural, denotando uma relação de subordinação dos direitos dos cidadãos aos chamados interesses maiores da Nação, ainda que de modo menos explícito do que nas constituições de 1967 e 1969. Subsiste a concepção herdada do período militar de atribuir papel instrumental à Educação mais que consagrá-la como direito universal.

Os itens da Carta de Goiânia reproduzidos a seguir, apontaram as condições de acesso à educação:

3 - O ensino fundamental com 8 anos de duração é obrigatório para todos os brasileiros, sendo permitida a matrícula a partir de 6 anos de idade.

4 - O Estado deverá prover os recursos necessários para assegurar as condições objetivas ao cumprimento dessa obrigatoriedade, a ser efetivada com um mínimo de 4 horas por dia, em 5 dias da semana.

5 - É obrigação de o Estado oferecer vagas em creches e Préescolas para crianças de 0 a 6 anos e 11 meses de idade, com atendimento prioritariamente pedagógico.

6 - São assegurados aos deficientes físicos, mentais e sensoriais serviços de atendimento pelo Estado, a partir de zero ano de idade, em todos os níveis de ensino.

7 - É dever do Estado prover o ensino fundamental, público e gratuito, de igual qualidade, para todos os jovens e adultos que foram excluídos da escola ou a ela não tiveram acesso na idade própria, provendo os recursos necessários ao cumprimento desse dever.

8 - O Estado deverá viabilizar soluções que compatibilizem escolarização obrigatória e necessidade de trabalho do menor até os 14 anos de idade e, simultaneamente, captar e concentrar recursos orçamentários para a criação de um Fundo de Bolsas de Estudos a ser destinado às crianças e adolescentes de famílias de baixa renda, matriculados na escola pública.

9 - O ensino de $2^{\circ}$ grau, com 3 anos de duração, constitui a segunda etapa do ensino básico e é direito de todos.

10 - O ensino, em qualquer nível, será obrigatoriamente ministrado em Lingua Portuguesa, sendo assegurado aos indígenas o direito à alfabetização nas línguas materna e portuguesa. 
11- Será definida uma carreira nacional do magistério, abrangendo todos os níveis e que inclua o acesso com o provimento de cargos por concurso, salário digno e condições satisfatórias de trabalho, aposentadoria com proventos integrais aos 25 anos de serviço no magistério e direito à sindicalização. (Anexo $B$ )

As propostas em relação à garantia de acesso à Educação se referem a todos os graus/níveis de ensino e diferem em vários aspectos do projeto Afonso Arinos. O primeiro deles é que a Carta introduz o conceito de educação básica comum. No que se refere ao conceito de educação ${ }^{32}$, mais abrangente do que o de ensino ${ }^{33}$, diz respeito ao processo de desenvolvimento da capacidade física, cognitiva/ intelectual e dos valores das crianças, jovens e adultos, enquanto que o conceito de ensino reduz-se à transmissão de conhecimento. Pode-se inferir do texto, ainda que a ideia não seja explícita, que a educação básica é constituída pela creche, pré-escola, ensino fundamental obrigatório e pelo ensino de $2^{\circ}$ grau, apresentado como segunda etapa do ensino básico.

A segunda refere-se à obrigatoriedade do Ensino Fundamental de 8 anos. A proposta atribui um novo nome ao antigo $1^{\circ}$ grau e torna a obrigatoriedade responsabilidade do Estado e, ainda que não indique a obrigatoriedade no caso do Ensino Médio, prevê que este é um direito de todos. E em relação à educação infantil, a Carta de Goiânia indica a necessidade de que o Estado assuma a responsabilidade pela oferta de vagas para crianças de 0 a 6 anos e 11 meses, com atendimento pedagógico. A referência à dimensão pedagógica aponta para a superação do trabalho apenas assistencial nesses equipamentos públicos.

O anteprojeto da Comissão Afonso Arinos estabelece a obrigatoriedade do ensino dos seis aos dezesseis anos, vincula recursos para 0 atendimento educacional nas esferas federal, estadual e municipal, todavia não esclarece qual o papel do Estado em relação a tal obrigatoriedade, o que equivale a torná-la um problema tanto público quanto privado. Melhor dizendo: a garantia da escolaridade entre os seis e dezesseis anos pode ocorrer a partir da oferta privada com a utilização dos fundos públicos, conforme se pode inferir da relação entre os artigos 387,388 e do artigo 391.

${ }^{32}$ Substantivo do latim educare que significa desenvolvimento da capacidade física, intelectual e moral da criança. (Cunha, 2012, p. 248)

${ }^{33}$ Verbo do latim insignare que significa transmitir conhecimento. (Ibidem) 
Dentre os itens seguintes merecem destaque as definições acerca do Ensino Superior. No item 13, a redação aponta que as universidades públicas, como as demais instituições de Ensino Superior, deverão ter funcionamento autônomo e democrático, proposição ausente do anteprojeto da Comissão Afonso Arinos, que trata das instituições de Ensino Superior apenas quando se refere, no artigo 391, à transferência de recursos públicos ao ensino privado e, ainda, no parágrafo $1^{\circ}$ do artigo 392: "a lei e os estatutos da Universidade proverão a aposentadoria antecipada nos casos de manifesta ineficiência acadêmica de titular da estabilidade" e no parágrafo $2^{\circ}$ : "é assegurada a inviolabilidade de docência e declarada nula a dispensa que se faça apenas pela divergência de opiniões, independentemente de tempo de serviço". (Brasil, 1986, p. 53)

Em relação às questões sobre financiamento, a Carta apontou:

14 - A lei regulamentará a responsabilidade dos Estados e Municípios na administração dos seus sistemas de ensino e a participação da união para assegurar um padrão básico comum de qualidade dos estabelecimentos educacionais.

15 - Os recursos públicos destinados à educação serão aplicados exclusivamente nos sistemas de ensino criados e mantidos pela União, Estados e Municípios.

16 - Será de responsabilidade exclusiva dos setores da Saúde Pública a atenção à saúde da criança em idade escolar.

17 - A merenda escolar e qualquer outro programa assistencial a ser desenvolvido nas escolas devem contar com verbas próprias, desvinculadas dos recursos orçamentários para a educação stricto sensu, porém gerenciadas por órgãos da área educacional.

18 - É permitida a existência de estabelecimentos de ensino privado, desde que atendam às exigências legais e não necessitem de recursos públicos para sua manutenção.

19 - O Estado deverá garantir à sociedade civil o controle da execução da política educacional em todos os níveis (federal, estadual e municipal), através de organismos colegiados, democraticamente constituídos.

20 - O Estado assegurará formas democráticas de participação e mecanismos que garantam o cumprimento e o controle social efetivo das suas obrigações referentes à educação pública, gratuita e de boa qualidade em todos os níveis de ensino.

21 - Fica mantido o disposto pela Emenda Calmon (EC 24, parágrafo $4^{\circ}$ do art. 176 da atual Constituição), assim como pelas Emendas Passos Porto (EC 23) e Irajá Rodrigues (EC 27) e a lei estabelecerá sanções jurídicas e administrativas no caso do não cumprimento destes dispositivos. (Anexo B). 
Além de propor que os recursos públicos deixassem de ser transferidos para instituições privadas, também indica o que não poderia ser considerado gasto com a educação: merenda. Os dois documentos anteciparam os principais debates que mobilizariam a atenção da Subcomissão de Educação nos meses de abril e maio de 1987. A primeira manifestação de mérito, realizada no âmbito da Subcomissão de Educação, como apontamos no Capítulo 1ํ, foi a do Constituinte Álvaro Valle (PLRJ) que, como já referido, apesar da defesa de uma constituição sintética, apontava a necessidade do tratamento de alguns temas, particularmente das conquistas asseguradas em outras constituições. Além das conquistas relativas à aposentadoria do magistério, garantia de aposentadoria para professoras aos vinte e cinco anos e para professores aos trinta anos, o Constituinte indicou a necessidade de extensão da escolaridade obrigatória dos cinco aos quatorze anos, isto é, ultrapassando a determinação de obrigatoriedade dos sete aos quatorze anos, incluindo o pré-escolar.

Acredito que esta Comissão daria uma satisfação aos educadores brasileiros no momento em que iniciássemos o debate substantivo daquele capítulo que votaremos aqui, dando ao pré-escolar a atenção que ele merece ter e não tem tido nos debates da escola brasileira e os problemas brasileiros de Educação. Discute-se muito a Universidade, discute-se muito primeiro e segundo graus, mas pouco se tem falado em pré-escolar, onde eu acredito, Senhor Presidente, tenha o maior e mais efetivo problema de democratização da escola brasileira.

Uma criança de classe média, ou uma criança, normalmente faz o seu pré-escolar de forma sistemática, começando em maternal, jardim de infância, a classe de alfabetização e tudo o mais. Caso não o faça, tem o pré-escolar sistemático em sua casa, com jogos educativos, com brinquedos, com tudo aquilo que uma família letrada, normalmente, utiliza para a educação de seus filhos: enquanto crianças mais pobres, aqueles que provêm das classes de mais baixa renda, normalmente, não têm pré-escolar, e muito raramente nós temos pré-escolar gratuito, neste País.

O resultado disso, Senhor Presidente, é que uma criança socialmente favorecida normalmente está alfabetizada aos 6 ou 7 anos, quando chega à escola aprende a ler e escrever em 2 ou 3 meses, sem dificuldade alguma para os alfabetizadores. Enquanto isso, uma criança que vem da favela da minha cidade, por exemplo, em geral, aos 7 anos, quando chega à escola, é apresentada pela primeira vez ao lápis e muito frequentemente perderá 1 ou 2 anos de sua vida para ser alfabetizada, e muitas vezes, culpam-se os alfabetizadores, imaginando-os menos competentes. Muitas vezes, o que é mais grave, o pai acredita que o seu filho não dá para o estudo, aí retira-o da escola, quando o teste do QI poderia indicá-lo 
mais inteligente, mais preparado do que aquela criança rica alfabetizada aos 5 anos [...]

$\mathrm{Na}$ realidade, essas duas crianças estão iniciando as suas vidas com oportunidades absolutamente diversas, e isto evidentemente irá determinar e influenciar todo o seu futuro e toda a sua formação escolar [...] o pré-escolar considerado também uma obrigação do Estado desde que a família não tenha outros meios, outras fórmulas para supri-lo para a criança entre 5 e 7 anos de idade. (ANC, 1988b, p. 13)

O discurso, constatando a desigualdade de possibilidades, constrói uma conexão entre a ausência de acesso à pré-escola e a não eficácia da alfabetização. A referida circunstância na vida das crianças geraria dois outros problemas: de um lado, culpabilizar o educador, considerado incompetente, quando este em verdade não teria responsabilidade, uma vez que a presença da pré-escola geraria alfabetização sem dificuldades para os alfabetizadores, já a sua ausência traria a necessidade de maior tempo, um ou dois anos. De outro lado, este fracasso geraria nos pais a crença de que seus filhos não teriam capacidade para estudar, podendo dessa forma ser retirados da escola.

No discurso, a oferta da pré-escola significava o diferencial que lançaria as crianças pobres em um futuro promissor. Como se pode verificar, os encadeamentos são estabelecidos de forma linear, uma circunstância apresentada como consequência da outra. Também não há referência à qualidade da ação pedagógica e do conjunto do trabalho escolar, de tal modo que não importaria a natureza do trabalho do educador e da escola, o currículo desenvolvido e as concepções teóricas a eles subjacentes, a política educacional desenvolvida em cada lugar, bem como a política estadual e nacional de educação. Em torno da noção de carência, o discurso movimenta a ideia de que as crianças pobres poderiam se equiparar às das classes médias ou às crianças ricas. Assim, a perspectiva de ascensão social poderia ser mobilizada para fundamentar os argumentos que se sobrepunham ao direito social universal à educação, levando a crer que o ideal das crianças pobres deveria ter acesso à educação privada.

Mas, embora a proposta de que o Estado atendesse gratuitamente as crianças de cinco a sete anos de idade cujas famílias não tivessem meios materiais para financiar diretamente a educação privada, está ausente do discurso do Constituinte que tal atendimento devesse ocorrer em redes públicas. Isto significa 
que esta oferta poderia ser realizada por meio de bolsas de estudo assegurando tanto a ação do Estado como a gratuidade. Estas razões permitem considerar que a defesa do direito à educação é consentânea à defesa dos interesses privados na educação. Em outro momento da discussão na Subcomissão, o constituinte Álvaro Valle (PL-RJ) afirmaria:

Embora não seja propriamente o tema da discussão, Senhor
Presidente, mas como já é a terceira referência que se faz, pela
terceira vez eu ouço que os recursos públicos devem ser destinados
exclusivamente à escola pública. Para que não passe essa
referência como algum pensamento unânime desta Subcomissão, eu
gostaria de fazer uma restrição à ideia. Eu acredito que os recursos
públicos devam ser destinados à educação. A escola pública no Brasil é uma escola geralmente ineficiente e cara. Quando se abre uma escola pública para mil crianças, mais do que está se dando escola a mil crianças, está se tirando mais ou menos de quatro mil outras, porque a escola privada, normalmente, custa pelo menos cinco vezes mais barato que a escola pública. De modo que eu não creio que, necessariamente, recursos públicos que existem para que sejam geridos, sobretudo com eficiência pelo Estado, necessariamente devam ser destinados à escola pública; acredito, sim, que devam ser destinados a um objetivo muito maior. A escola pública é o instrumento, o grande objetivo é a educação do País; a educação da juventude é a formação de nossa gente [...]. (Ibidem, p. 17)

Novamente, a operação discursiva se fundamenta na naturalização de afirmações cuja comprovação sequer é cogitada. É o caso da suposta ineficiência e do custo elevado da escola pública. A premissa, como processo abrangente e universalizante, não permite a análise das afirmações, a consideração das diferenças regionais e locais e, tampouco, a compreensão das questões nacionais como condições de financiamento, estrutura, funcionamento e legislação sobre a área. Também neste caso não proporciona a possibilidade de interpretação da política educacional levada a efeito pelos entes federados responsáveis por diferentes níveis da oferta educacional.

A afirmação sobre a ineficiência da escola pública, oposta à eficiência do privado, tornava invisível e incompreensível a complexidade dos desafios envolvidos na garantia do direito à educação. A substituição do público pelo privado estaria, no campo discursivo, a serviço da construção de uma representação social e nacional que sustentaria a abertura de um novo mercado de trabalho, organizado em torno do atendimento da obrigatoriedade da pré-escola no País. A eficiência anunciada na 
manifestação de João Calmon (PMDB-ES) estava inescapavelmente associada à disputa relativa aos fundos públicos, tornando claro que o apelo ao não esquecimento das constituições anteriores não foi apenas uma alusão voltada à preservação dos direitos dos professores, mas estava em questão a garantia dos interesses dos grupos privados do ensino, historicamente associados à remuneração de bolsas de estudo pelo estado.

Dando sequência à apresentação de propostas, o Relator Calmon apontou a necessidade de aumento, "de uma vinculação de um percentual mínimo dos orçamentos públicos para o ensino". (Ibidem, p.14) Ao que tudo indica, esta foi uma conquista do Congresso Nacional, através de uma emenda que seria objeto também preliminar, porque havia várias posições, inclusive do aumento desse percentual na área federal, embora condicionado à reforma tributária que estava sendo cogitada (Ibidem, p. 15) - como o está ainda hoje, uma vez que é uma necessidade imperiosa no Brasil.

\section{3 - As diferentes faces do financiamento}

$\mathrm{Na}$ trigésima primeira reunião da Subcomissão, em dezenove de maio, o constituinte João Calmon (PMDB-ES) apresentou "um dos pontos principais do anteprojeto - a fixação de um percentual mínimo dos orçamentos públicos para a educação." (ANC, 1987, p. 489)

Em um primeiro momento, o constituinte situou o tema:

[...] essa vinculação [orçamentária] iniciou-se em 1934. Foi mantida, sem nenhuma alteração, pela Constituição de 1946. Foi eliminada da Constituição de 1967, sob a mesma alegação que está sendo invocada pelo Relator de uma das subcomissões, que é radicalmente contrário à vinculação de quaisquer percentuais dos orçamentos públicos para a educação, sob a alegação de que há outras áreas também que necessitariam de recursos. [...]

$\mathrm{Na}$ Assembléia Nacional Constituinte atual, várias propostas têm o objetivo de acrescentar, depois de "manutenção e desenvolvimento do ensino..." o adjetivo, "público", e a explicação é óbvia, os parlamentares autores dessas propostas temem que se não houver o acréscimo desse adjetivo, "público", que os recursos para a educação vão sofrer um grave desfalque, um desvio deplorável, e esta é a explicação que estou procurando dar aos nobres colegas desta Assembléia Nacional Constituinte. (Ibidem, p. 490-1) 
O debate sobre esse tema fundamental pautou reiteradamente a Subcomissão. Entre as diferentes posições em disputa, o constituinte Sólon Borges dos Reis (PTB-SP), na 9ª reunião da Subcomissão da Educação, Cultura e Esportes (21 abr. 1987), desconsiderou a possibilidade de manifestação sobre o financiamento, em função do entendimento de que tal tema dependeria do regime tributário a ser adotado, assunto que não dizia respeito àquela Subcomissão. (ANC, 1988b, p.14)

Nesse contexto, o constituinte Ubiratan Aguiar (PMDB-CE) defendeu: a aposentadoria de vinte e cinco anos para professores e professoras; a alfabetização das crianças com início aos seis anos; a escolaridade obrigatória estendida até os quatorze anos; e, ainda, que os recursos públicos fossem destinados exclusivamente para as escolas públicas. Em sua opinião, as escolas particulares deveriam ter liberdade de existir, mas deveria ser vedada sua sustentação ou manutenção pelo Poder Público.

O constituinte Louremberg Nunes Rocha (PMDB-MT) argumentou que o detalhamento de propostas evocado pelo constituinte Florestan Fernandes deveria se concretizar, em primeiro lugar, em relação à destinação de recursos. Dessa maneira, propunha que o pagamento das aposentadorias, cerca de $3 \%$, estivesse sob a responsabilidade da Previdência, isto é não pagas com os 13\%, ampliando os recursos a serem investidos, por exemplo, na extensão da educação pública dos cinco aos dezesseis anos. (Ibidem, p. 15)

O relator João Calmon, contestando as informações referentes aos gastos com aposentadorias, apontou a necessidade de discussão sobre se seria lícito, por exemplo, o gasto com merenda escolar, apesar da pertinência de investimentos da ordem de cinco bilhões de cruzados, à época, nessa área (Ibidem). Desta maneira, o senador abria o debate sobre o que seriam, efetivamente, os gastos com manutenção e desenvolvimento do ensino. Nesse contexto, o constituinte Louremberg Nunes Rocha indicou a necessidade de que todas as propostas apresentadas fossem discutidas, considerando-se os respectivos custos e o impacto em relação ao percentual vinculado à Educação, condição da exequibilidade das propostas. 
As propostas iniciais apresentadas pelo Constituinte Chico Humberto (PDTMG) foram no sentido de tornar a escolaridade obrigatória entre os cinco e dezesseis anos, assegurando-se a Educação de Jovens e Adultos que, por diferentes motivos, não tivessem tido a oportunidade de ter acesso à escola. Tratava-se de estender a gratuidade também aos que não tiveram acesso à educação na idade própria. Também sugeriu o atendimento público, gratuito e especializado aos portadores de deficiências físicas e mentais. Além disso, expressou concordância com a proposta de aposentadoria dos professores (homens e mulheres) aos vinte e cinco anos e indicou a necessária utilização dos livros didáticos de $1^{\circ}$ e $2^{\circ}$ graus por cinco anos, de modo a evitar que as editoras trocassem o livro didático a cada ano, induzindo compras anuais em grande escala.

Apontou ainda o dever dos pais em relação à educação dos filhos e a obrigação do Estado para com a educação. Propôs que os percentuais de vinculação dos recursos para a área fossem equiparados, isto é, $25 \%$ dos recursos da União para a educação, enquanto aos estados e municípios a vinculação deveria se manter em $25 \%$. O deputado manifestou-se ainda sobre as competências de oferta educacional de cada uma das esferas de governo: aos municípios deveria competir a oferta do ensino pré-escolar, primário e da merenda escolar; os Estados seriam os responsáveis pelo ensino de $2^{\circ}$ grau e pelo colegial até o universitário ${ }^{34}$. Já a União deveria assumir a responsabilidade pelo Ensino Superior e auxiliar com recursos aos municípios carentes. Por fim, Chico Humberto defendeu recursos públicos para as escolas públicas e a garantia de livre iniciativa na área da Educação.

O debate sobre propostas gerais para a área e sobre condições de financiamento continuou, com a manifestação do Constituinte Átila Lira (PFL-PI). Ele defendeu que o Estado brasileiro assumisse plenamente a função educacional (ao lado da saúde e da segurança); indicou a necessidade de que se partisse dos valores conquistados constitucionalmente, os $13 \%$; mostrou-se partidário da tese de que os gastos com merenda e material deveriam ser excluídos do percentual, e que esses recursos deveriam ser destinados para pessoal, investimentos, expansão e adequação das redes de ensino.

\footnotetext{
${ }^{34}$ A essa altura o colegial não mais existia, tampouco o ensino primário. Em vez disso tínhamos, de acordo com a 5.692/ 71 os ensinos de $1^{\circ}$ grau, com duração de 8 anos (7 a 14 anos) e $2^{\circ}$ graus, com três anos de duração (14 aos 17 anos). De qualquer modo, compreendemos o sentido.
} 
Vejo também como proposta fundamental, o rigoroso controle dos gastos públicos na área de Educação. Ninguém conhece, mesmo agora na chamada nova República, com a maior clareza, o que é que os Estados gastam ou se gastam adequadamente, e a própria União, na aplicação desses recursos.

Então, não vejo por que só a Assembléia Legislativa e as Câmaras de Vereadores tenham essa autoridade para representar toda a comunidade brasileira. Creio que os Conselhos Comunitários e os próprios sindicatos ou as formas institucionais de organização da sociedade devam exigir, mais do que nunca, com a maior clareza, o que diz respeito à aplicação desses recursos. (Ibidem, p. 16)

Embora o anunciado rigor em relação ao que seriam os gastos com a educação, sobre o investimento dos recursos públicos, afirma o parlamentar:

[...] Com relação aos recursos públicos para a escola pública, tenho uma total paixão - inclusive, creio que se fizermos um plebiscito aqui, neste momento, será uma vitória dentro deste Plenário - mas, na medida em que viermos a melhor discutir a questão, vamos ficar preocupados, por exemplo, com a questão da escola da igreja, seja ela católica, seja ela protestante, porque, de qualquer jeito, temos que procurar preservar. (Ibidem)

No que toca à relação entre competências das três esferas de governo e o aporte de recursos para financiar as ações a elas correspondentes na área da educação, isso é, à municipalização do ensino, o constituinte Átila Lira (PFL-PI) assim se pronunciou:

Com relação à municipalização do ensino, é um tema que quero colocar, aqui, para ser debatido, porque também tenho aquele princípio de partida da compreensão da questão educacional. Acho que a maior luta que temos, hoje, nesta Constituinte, é a questão da quebra do excesso de poder do Estado em relação à Federação e em relação ao próprio cidadão e a municipalização é uma forma, eu creio, de descentralização desse poder e mais do que nunca, já se viu, não só com relação à educação, como saúde, que, um dos pontos básicos da busca de uma democratização do ensino e eficiência do ensino, porque creio que também buscamos isto, está relacionado com a municipalização, com a descentralização do poder, não é uma prefeiturização [sic]; não é uma tentativa de criar algo original, no sentido de fazer com que a comunidade de transferir para o Estado, também este poder, mas uma tentativa seja mais presente no que diz respeito ao seu plano educacional, a sua ação educacional, e ao controle do que é necessário para investir nessa educação. (Ibidem, p. 17)

A municipalização foi apresentada no discurso como forma de descentralização do poder do Estado em relação às políticas públicas e, também, 
em relação à vida dos cidadãos, mostrando-se em sintonia tanto com a oferta obrigatória do então chamado ensino pré-escolar a partir dos cinco anos, quanto em relação à garantia de recursos públicos para a escola privada, "mais barata que a escola pública". Note-se que a proposta de municipalização foi apresentada pelo deputado antes mesmo de outras considerações acerca das competências em relação ao conjunto das atribuições educacionais a serem estabelecidas para todas as esferas de governo. Tampouco fez referência ao padrão de desenvolvimento econômico, social e cultural dos municípios - mais precisamente, a condição de desigualdade entre eles no País. As dificuldades de financiamento historicamente conhecidas tornavam possível que a obrigatoriedade da pré-escola proposta se tornasse um poderoso impulso à expansão das escolas privadas neste nível de ensino, que teriam, de acordo com a lógica do deputado, a possibilidade de disputar recursos públicos para realizar 0 atendimento das crianças. Com efeito, a obrigatoriedade da pré-escola, a municipalização e a proposta de verbas públicas para a escola privada compõem um constructo político voltado aos interesses do mercado educacional no Brasil.

Também sobre a municipalização, o constituinte Sólon Borges dos Reis (PTBSP) indicou:

Quanto à municipalização a que se referiu o constituinte Átila, está na linha da descentralização de que o Brasil precisa: a descentralização política administrativa, educacional, só que a municipalização, em si é também parte do processo surrealista com que se estuda a realidade brasileira, inclusive da nossa legislação. Nós temos a Lei de Diretrizes e Bases, por exemplo, que diz que paulatinamente o ensino básico, o antigo primário, antigo grupo escolar, mais ginásio e o primeiro grau [sic] passarão para a responsabilidade da Prefeitura. Mas com que recurso? Se as prefeituras ficam com, de cada cem cruzados que se paga de imposto numa cidade, num dos municípios brasileiros, não ficam dez cruzados no município, tudo vem para Brasília, embora $30 \%$ fiquem nos Estados, que arcam com todo o ensino, e Brasília tem todas as loterias que existem e talvez ainda possa regulamentar outras formas de arrecadação. Então, tudo vai depender do regime tributário. Se o regime tributário não for descentralizador, nós não vamos pensar em municipalização, mesmo que a lei diga, e a lei como é surrealista, ela mostra que uma coisa é o Brasil real e outra é o Brasil legal [...]. Quem sabe se o ideal não seria, se houvesse recursos, que os Municípios ficassem com o primeiro grau, os Estados com o segundo grau e a União com o ensino superior? Mas precisaria haver uma distribuição de recursos que permitisse essa divisão de atribuições descentralizadoras. (ANC, 1988b, p.17) 


\section{E, depois de vários apartes, concluiu:}

Eu vou concluir, Sr. Presidente, dizendo que estou partindo do princípio de que o dinheiro público é escrupulosamente e racionalmente utilizado. Sempre sustentei, inclusive tenho livro publicado sobre isto, de que não basta ganhar mais é preciso gastar melhor. E é fácil mostrar o desperdício que há na educação brasileira. Agora vejo também a corrupção: os jornais noticiaram, mas depois não se deu mais andamento à notícia, de desvios de recursos da Universidade de Pernambuco e também parece que em Curitiba, no Paraná. Então me parece que entramos no terreno da corrupção. Mas mesmo sem entrar no terreno da corrupção, e não é nesse terreno que eu prefiro entrar, é fácil demonstrar o desperdício em matéria da manutenção e desenvolvimento de ensino neste País. (Ibidem, p.18).

Há, no discurso, uma clara identificação entre municipalização, descentralização e reforma tributária. A descentralização suporia, nas palavras do deputado, uma ampliação de competências dos municípios, no contexto de uma nova divisão de responsabilidades institucionais entre municípios, estados e União, mas a única implicação fortemente indicada dizia respeito à repartição dos recursos públicos no país. O constituinte não se manifestou em relação a um sistema que articulasse as competências e responsabilidades e promovesse cooperação entre os entes federados, debate em vigor desde 1932, quando foi lançado o Manifesto dos Pioneiros da Educação Nova, tampouco fez qualquer referência às desigualdades regionais, aos padrões de desenvolvimento dos municípios e das regiões ${ }^{35}$ e às dificuldades decorrentes de tal realidade, como necessidade de existência de corpo

35 De acordo com o Relatório sobre o Desenvolvimento Humano no Brasil (1996), de responsabilidade do IPEA e PNUD, existiriam três Brasis, da perspectiva do índice de desenvolvimento humano (IDH): o Brasil do Sudeste (exceto Minas Gerais), do Sul, do Distrito Federal e do Mato Grosso do Sul, apresentaria elevado nível de desenvolvimento humano; o Brasil de Minas, Goiás, Mato Grosso, Rondônia, Amazonas e Amapá, considerado como integrante do nível de desenvolvimento humano médio; e o Brasil do nível de desenvolvimento humano mais reduzido, constituído por Pará, Acre, Tocantins e todos os estados do Nordeste. Com relação a este último conjunto, é importante destacar que os nove estados nordestinos estavam nos nove últimos lugares, considerada a classificação para as 26 unidades da Federação. Em relação aos indicadores de pobreza, verificou-se maior concentração no Norte e, sobretudo, no Nordeste, em comparação com as demais regiões. Com uma população equivalente a $29 \%$ do total do país, o Nordeste abrigava $45 \%$ dos pobres brasileiros. A porcentagem de domicílios com abastecimento de água e esgotamento sanitário também foi mais baixa no nordeste. Em relação aos aspectos econômicos, os indicadores mostravam, no que se refere ao produto interno por habitante, que o Nordeste registrava um nível que corresponde a menos da metade do produto interno brasileiro. No Sudeste, Sul e Centro-Oeste, os valores encontrados eram maiores que o da média nacional. Em relação à produtividade (produto dividido por população ocupada), a nordestina correspondia a um terço daquela encontrada no Sudeste e à metade da registrada para o Sul. Tais valores se repetiriam quando se considerasse a produtividade da agropecuária, e seriam um pouco menores quando se analisasse o segmento industrial. A estimativa para a região Norte não foi realizada em função da indisponibilidade de dados. (Neto, 1997, p. 46) 
técnico para o gerenciamento da educação, de profissionais habilitados, de universidades próximas visando à qualificação do trabalho pedagógico, o que contrastou fortemente com o discurso sobre os gastos excessivos, em função de supostos desperdícios e situações de corrupção.

Esta posição guardava relação com as afirmações de Átila Lira (PFL-PI) sobre a ineficiência e o custo das escolas públicas em relação às privadas. Melhor explicando: a municipalização era apresentada como perspectiva dissociada de uma estrutura capaz de promover a articulação entre os entes federados visando a oferta educacional pública em termos nacionais. A contra face dessa incipiente proposta é sua condição instrumental, isto é, se associada à obrigatoriedade da oferta, poderia se constituir em condição facilitadora da luta pela transferência de recursos públicos para escolas privadas, na medida em que a realidade dos municípios, mesmo com maior volume de recursos, não permitiria a construção de escolas, a formação de educadores e a estruturação de equipes técnicas nos departamentos de educação, em curto espaço de tempo.

Por sua vez, ao retomar a manifestação de Álvaro Valle (PL-RJ), é possível observar que o movimento discursivo se apoia na noção de carência das crianças pobres - que integra o ideário liberal -, não se ocupando do direito. É interessante lembrar que o direito como coisa pública pertence a todos de modo coletivo, ao mesmo tempo em que é comum, isto é, diz respeito a todos os indivíduos de modo distributivo.

Desse modo, a coisa pública é pública porque não pertence como propriedade a ninguém em particular e sim a todos e é comum porque cada qual pode participar de seus benefícios. Assim [...] temse que o público se opõe ao privado (como singular ou como familiar) e comum se opõe ao particular (entidade grupal de ordem privada). Mas o público é, também, o que é pertinente ao Estado como guardião de interesses maiores e gerais que pairem sobre as dimensões privadas e os interesses particulares. (...) O público não é o lugar dos segredos, próprios dos desejos de tiranos (déspotas) ou ditadores em tudo contrários à razão e à liberdade [...]. (Cury, 2009, p.81-82)

Opondo-se à abordagem de Álvaro Valle, o constituinte Chico Humberto (PDT-MG) afirmou:

[...] ele se esquece de dizer que o custo da escola privada é duas vezes onerado aos cofres públicos, uma vez porque recebe bolsas 
de estudo, e outra vez porque o pai da criança que estuda em escola particular desconta do Imposto de Renda o valor que paga do ensino de seu filho. Então, na verdade, é um custo muito maior do que se apresenta normalmente, porque esse custo, que é descontado do Imposto de Renda, do país, que pode, pelo menos, pagar o ensino particular do seu filho numa escola diferenciada, numa escola discriminadora, numa escola que não atende, na verdade, às necessidades do povo brasileiro, ele se beneficia quando faz a sua declaração do Imposto de Renda. Então essa imagem que se passa de que a escola pública custa quatro vezes mais cara, primeiro não é verídica, porque a escola particular também onera os cofres públicos, porque uma vez que se desconta o Imposto de Renda ele na verdade está usando o dinheiro público onde as oportunidades não são as mesmas das escolas particulares. (ANC, 1988b, p. 18)

A contraposição realizada pelo constituinte Chico Humberto (PDT-MG) remete à discussão acerca do custo-aluno na escola pública e na escola privada. Pretendeu o constituinte explicitar dois mecanismos de transferências dos fundos públicos para as escolas privadas. Em verdade o debate tornava pública a ausência de estudos em nível nacional, estadual e municipal acerca dos investimentos públicos por aluno nas escolas públicas e privadas.

Os gastos governamentais, em todos os níveis, com educação, em 1983, corresponderam a cerca de $3,2 \%$ do PIB compreendidos recursos orçamentários e extra orçamentários. Em 1986 era de 3,5\% do PIB.

O montante dos gastos pessoais com educação constitui valor ignorado, obtendo-se quando muito o valor informado pelas pessoas físicas que declararam renda para efeito de imposto. De todo o modo, esses dados se referem à parcela da população de mais alta renda (Cunha, 2009, p. 299)

Cunha tomando como referência os estudos de Velloso (1988) demonstrou que em 1986 o governo federal aportou como subsídios ao setor privado valores da ordem de Cz\$ 2 bilhões sendo que deste montante estavam excluídos bolsas de estudo de pós-graduação, subsídios na forma de juros negativos dos empréstimos do Fundo de Apoio ao Desenvolvimento, os empréstimos do Programa de Crédito Educativo e os recursos dos convênios da Financiadora de Estudos e Projetos a título de apoio institucional a pesquisas. Os valores destinados às instituições privadas representaram quase o dobro do que o MEC enviou às secretarias estaduais de educação como apoio ao então $1^{\circ}$ grau, foi equivalente a 1,4 vezes ao total dos investimentos na pós-graduação. (Ibidem, p. 302). 
Observe-se que entre os anos de 1986 e 1988 houve um aumento da receita para a educação em função da retomada da vinculação orçamentária no País com a vigência da emenda constitucional no 24 de 1983, a chamada emenda Calmon. Dois problemas, que marcaram a história da educação republicana, estiveram associados à ampliação de recursos. O primeiro, discutido durante todo o trabalho da Subcomissão, diz respeito à utilização dos fundos públicos da educação em outras áreas, merecem registro os expressivos gastos com servidores públicos de outras secretárias e, ainda, com a estrutura administrativa dos órgãos da educação. Tais procedimentos dificultaram sobremaneira que os recursos públicos chegassem à sala de aula. O segundo problema se refere aos critérios para distribuição de recursos ou, melhor dizendo, à falta deles. Valendo-se das tradições de nossa cultura política o governo da Nova República reforçou as práticas institucionais não republicanas (Ibidem, p. 300).

\begin{abstract}
Além de tudo, a prática de se fazer essas transferências mediante "projetos especiais", elaborados pelos estados, pelos municípios e por entidades privadas, com a intermediação de deputados e senadores, dava a marca do clientelismo, isto é, da utilização de recursos públicos que deveriam ser empregados no ensino, mas que acabavam por servir a propósitos eleitorais dos ocupantes dos cargos públicos.

(...) Com um aspecto da privatização da coisa pública, ou seja, da utilização de recursos públicos para apoiar a acumulação privada de capital, os subsídios governamentais ao ensino privado têm sido no Brasil um dos importantes eixos por onde se exerce tal apoio. Neste caso, mais do que em outros, o caráter antidemocrático da transferência de recursos públicos para o ensino privado se revela sem disfarces. Esse fato é tão mais grave quando se leva em conta que os recursos fazem falta não só para a expansão quanto para a própria manutenção do ensino público (Ibidem, p. 301).
\end{abstract}

O debate seguiria na reunião tendo como foco a vinculação de recursos para a educação e sua ampliação, como é possível constatar nas palavras do Constituinte Ubiratan Aguiar (PMDB - CE):

Eu não chegaria a tanto e até já pensei, num determinado momento, como o professor André Getti, da Universidade Federal do Ceará, que diz que se houvesse até a estatização, as minorias que detêm os privilégios conseguiriam puxar de tal forma a melhoria da qualidade de ensino na escola pública, que em pouco tempo nós alcançaríamos patamares nunca dantes imaginados por todos nós. Mas, sem chegar ao que pensa André Getti, eu entendo que é o momento de todos nós destinarmos os poucos recursos públicos, que durante muito tempo foi muito menos de $5 \%$ do Orçamento da 
União, e que através do nosso Relator João Calmon passou para $13 \%$, e de que precisamos até aumentar esse percentual para que possamos alcançar uma escola pública desejada pela sociedade brasileira. (ANC, 1988b, p.19)

Descartando a estatização como perspectiva para a educação, o constituinte retoma a questão do custo-aluno na escola pública alertando para o que chamou de custo social da escola pública, a saber: alimentação, saúde e livros didáticos. Tais custos, considerados por ele necessários, tornariam maiores os investimentos na educação pública. Indicou ainda que o salário pago pela iniciativa privada seria "muito mais miserável" do que aquele pago pelo poder público ao magistério o que também explicaria o custo mais baixo da escola privada.

Comparando os custos das escolas privadas e públicas afirmou ainda:

Os custos sociais não podem ser mensurados pelos lucros obtidos pela escola particular, pela iniciativa privada. Nós precisamos é melhorar, é puxar para que a melhoria da qualidade do ensino na escola pública venha através de uma maior soma de recursos que vá se manifestar no salário do professor, em primeiro lugar, nas condições de instalação de laboratórios, nas condições de instalação de laboratórios, nas condições físicas das próprias escolas para o atendimento de toda essa clientela (Ibidem, p.19)

No contexto do debate o constituinte Florestan Fernandes observou que as escolas particulares gozavam de isenções tributárias e empréstimos preferenciais e, que, portanto, havia gastos não visíveis onerando os cofres públicos razão pela qual a ideia de que o ensino privado seria mais barato e eficiente não passava de uma fantasia.

Retomando o problema da crise da educação pública durante os governos militares o constituinte Chico Humberto (PDT-MG), sem pretender confrontar-se com as escolas particulares discutiu a necessidade de igualdade de oportunidades para todos os cidadãos brasileiros.

Sobre gastos com manutenção e desenvolvimento de ensino como forma de direcionar e ampliar os gastos com educação, o constituinte Gumercindo Milhomem (PT-SP), na condição de professor da educação pública e privada, manifestou preocupação e desconfiança com relação às afirmações do constituinte Álvaro Valle (PL-RJ) e expressou-se em relação aos gastos com manutenção e desenvolvimento de ensino. 
[...] também desconfio muito das estatísticas que são citadas sem que se saiba, exatamente, qual é a fonte, de onde veio, como fez isso, com que objetivo que foi feito. [...]

Recentemente, no Rio Grande do Sul, os professores, através do Centro de Professores do Rio Grande do Sul, andaram envolvidos em um censo para que se descobrisse quem eram realmente aqueles professores [que] estavam realmente na escola. $O$ que tem se descoberto lá, como eu acho que aconteceria na maior parte do País se fosse feito um trabalho dessa maneira, é que existem dezenas, talvez mais do que dezenas de milhares de professores, de funcionários públicos contratados para a Secretaria de Educação e que prestam serviços em outras secretarias. Além do fato que tem sido até explorado, talvez com objetivos não expressos pela grande imprensa, de funcionários que, na verdade, nunca exerceram sua função em nenhuma repartição pública. Isto é verdade! Mas nós não podemos colocar isto na rubrica da educação como um problema da escola pública [...].

Hoje os números - como se diz hoje em dia - conservadores do MEC dão conta de 8 milhões de crianças na idade escolar que não estão frequentando a escola. Essas crianças não estão frequentando a escola só por causa da escola, mas porque têm que tomar conta do irmão mais novo enquanto os pais vão para o trabalho, ou porque têm elas mesmas que ir trabalhar para completar o orçamento doméstico, não têm camisa para ir à escola, não tem material didático, etc. São aquelas crianças que necessitariam, elas mais ainda do que as outras, do amparo público da escola pública [...].

Se nós considerarmos o fato de que esse número do MEC, 8 milhões em idade escolar não frequentando a escola, é um número contestado pelas contas do próprio Instituto Brasileiro de Geografia e Estatística, que aponta um número substancialmente maior, conforme divulgado pela Campanha da Fraternidade desse ano, da CNBB, nós só poderemos realmente ficar com a posição, reforçar essa posição, de que se tudo que se gastar na educação, ainda no Brasil, em face das nossas necessidades, é pouco, mas ainda nós devemos dizer: não se pode gastar em educação nada que seja em detrimento da escola pública. (Ibidem, p. 20).

Identificando a necessidade de que os números públicos precisos e confiáveis em relação ao número de crianças em idade escolar fora da escola, por parte do Ministério da Educação fossem elaborados, posto que poderiam ser maiores que aqueles apresentados pelo MEC e, ainda, que a maioria dessas crianças necessitava, por suas condições familiares e sociais, de políticas de apoio material para que pudessem frequentar a escola, o deputado considerou que, inversamente ao que propôs o constituinte Álvaro Valle (PL-RJ), os investimentos públicos não poderiam ocorrer em detrimento da escola pública, isto é em benefício da educação privada. 
O debate sobre vinculação teve prosseguimento, na $11^{\text {a }}$ reunião ordinária da Subcomissão, e o Constituinte Chico Humberto (PDT-MG) defendeu tanto e a vinculação de receitas quanto o aumento de seu percentual:

Temos sim que defender $25 \%$ da aplicação do orçamento da União, e isso não é sem razão que fazemos; esse é o exemplo de nações que querem se desenvolver, como Japão, a França, os Estados Unidos, que aplicam, que investem no futuro de sua pátria. (Ibidem, p. 38)

E no circuito de elaboração do anteprojeto, na $31^{1}$ reunião de 19 de maio de 1987, as preocupações do relator provocam:

Repito o meu temor, destaco o meu temor: se não agimos em conjunto, num bloco monolítico. Se alguém tivesse ainda qualquer dúvida, bastaria lembrar o pronunciamento do Relator de uma das Subcomissões que fulminou qualquer vinculação de recursos públicos para quaisquer finalidades.

Então, em relação a minha ideia fixa, a minha obsessão eu creio que até modestamente, sem essa intenção, eu superei alguns dos meus nobres, dos meus admiráveis companheiros que fazem restrição ao texto deste artigo.

O nobre Constituinte Octávio Elísio, creio que propõe o percentual de $15 \%$ no seu excelente trabalho que incorporei, como uma justa homenagem ao seu esforço, ao meu relatório.

O nobre Constituinte Florestan Fernandes, também, se não me engano propõe a manutenção dos $13 \%$. Tomei a iniciativa de aumentar para $18 \%$

Coloco, para meditação dos nossos companheiros, este ponto; a educação tem inimigos em numerosos setores deste País, esta Subcomissão, obviamente, não vai elaborar o texto final da nova Carta Magna. Estamos no primeiro nível da Constituinte, Subcomissão. Obviamente qualquer decisão tomada ao nível de Subcomissão pode ser modificada na área da Comissão de Sistematização e ainda mais em duas oportunidades no Plenário da Assembléia Nacional Constituinte.

De maneira que encerro esta exposição preliminar dedicada, exclusivamente, a este ponto, porque esta luta custou sacrifícios, esforços durante 18 anos, 18 árduos anos. Conseguimos vencer a batalha e, agora, tentaremos o novo aumento destas verbas e estou certo, estou absolutamente certo, de que na hipótese se ser aprovada esta proposta do Relator, os recursos para universidades não estatais diminuirão substancialmente, porque as exigências feitas para que elas recebam qualquer auxílio governamental são realmente muito rigorosos.

$\mathrm{E}$, repetindo, para encerrar. O meu único receio é de que se houver, de uma hora para outra, ou dentro de pouco tempo, um aumento do percentual de estudantes nas universidades públicas, que 
atualmente é de apenas $30 \%$ para 50 ou $60 \%$, a totalidade dos recursos federais para educação se destinará, exclusivamente, ao ensino superior, enquanto, até mesmo a Carta Universal dos Direitos do Homem declara, num dos seus artigos, que é um direito inalienável do ser humano um curso fundamental completo com a duração de 8 anos.

Falo, portanto, em nome das crianças que não votam, que não participam de qualquer manifestação, que não têm capacidade de arregimentação. Acho que essa minha preocupação é exatamente igual a de todos os nobres Constituintes que integram esta Subcomissão. (Ibidem, p. 491)

O discurso do relator, senador João Calmon, no contexto do debate acerca do anteprojeto por ele apresentado, na 23aㅗ reunião da Subcomissão (11 mai. 1987), traduzia um conjunto de contradições que, notadamente, marcavam os discursos e as práticas da Aliança Democrática à frente do governo da Nova República.

Reportando-se, em especial, aos constituintes Otávio Elísio e Florestan Fernandes, que se contrapunham a destinação de recursos públicos para instituições privadas, o autor procurava apresentar o aumento da vinculação como uma espécie de compensação necessária a garantia de transferência de recursos públicos para instituições privadas.

Valendo-se de longa análise sobre a história da vinculação de recursos para a educação nas constituições brasileiras, valendo-se também daqueles que no âmbito do Congresso Constituinte e do governo se contrapunham à vinculação e, ainda, da manifestação da maioria das entidades a favor da ampliação da vinculação, o relator pretendia demonstrar que nunca no Brasil a transferência de qualquer parcela de recursos públicos para instituições não estatais teria sido tão rígida. Declarava o temor em relação à possibilidade de que a destinação de verbas públicas para as escolas públicas gerasse o colapso das instituições confessionais e, portanto, uma demanda calculada entre 50 a 80 mil estudantes para as universidades públicas. 0 autor expressava a preocupação com o fato de que tendo o governo federal que se ocupar de atender tais alunos nas Universidades Públicas ampliaria os investimentos no ensino superior deixando de atender o ensino fundamental, considerado por ele como prioritário.

Ora, parece evidente que tal contraposição, assim formulada, deixava de considerar qualquer princípio de planejamento educacional posto que a construção de universidades para atender tal demanda não seria imediata devendo, por isso, 
prever tempo, recursos e, em decorrência, procedimentos de transição na futura constituição.

O desiderato das instituições particulares, especialmente confessionais, era transmutado no plano discursivo e tomava a forma de imperiosa necessidade para que não houvesse ameaça potencial aos interesses da maioria das crianças brasileiras. Tratava-se de um falso problema, pois não se pode notar no discurso qualquer indicativo de prospecção, no tempo e no espaço, visando tanto a universalização do ensino fundamental, com a participação da União, quanto a ampliação progressiva das universidades públicas. O discurso não toca, por sua vez, no papel que teriam para a universalização do ensino fundamental, os recursos do salário educação.

Estava criada uma oposição artificial, entre o ensino fundamental (e demais níveis da educação básica) e o ensino superior públicos que deixaria lastro nos debates educacionais ulteriores.

O constituinte Florestan Fernandes ao se contrapor ao relator expressou:

Eu não compartilho da visão pessimista do Relator, do colapso. Por quê?

Porque até hoje não houve o colapso. Se houvesse ameaça de colapso, ele já teria ocorrido. Ou, então, está escondida de nós todos uma participação do Governo no financiamento da escola privada uma quantia que é desconhecida pela Nação. Ou o Estado está pondo dinheiro lá e a gente não sabe de onde, nem como, mas numa escala muito grande, ou então esse risco é apenas uma hipótese, e nós aqui não podemos trabalhar com essa hipótese. Nós temos que trabalhar com princípios, eu acho que não País com os problemas do Brasil é fundamental que os recursos públicos sejam destinados a serviços públicos. (Ibidem, p. 494)

Florestan Fernandes considerando que quando o Brasil deixasse de ser uma Nação pobre, subdesenvolvida, com desenvolvimento desigual a questão pudesse ser revista, reafirmou a convicção de que o dinheiro público deveria ser destinado à educação pública.

No contexto do debate merece destaque a consideração do constituinte Octávio Elísio que, também defendendo recursos públicos para a educação pública, destacou a necessidade da Lei de Diretrizes e Bases da Educação (LDB) que, na condição de Lei Complementar, deveria concretizar as determinações 
constitucionais passíveis de regulamentação. Expressando a posição de outros deputados constituintes defendeu que $\mathrm{o}$ projeto fizesse referência a um Plano Nacional de Educação Plurianual que:

[...] amarre metas e recursos, que articule ações de União, Estados e Municípios, para que possamos, de fato, trazer, aproximar a realidade de miséria de educação, como já foi insistida aqui nesta Subcomissão, e o nosso projeto, o nosso desejo de educação, a nossa utopia em termos de educação, retratada na nossa Constituição. (Ibidem, p. 495)

O constituinte indicava a necessidade de um planejamento nacional da educação que, baseado em padrões de racionalidade, envolvesse as necessidades dos entes federados e os recursos disponíveis no País, depois de aprovada a Constituição.

Ao convocar os educadores que estavam participando do processo de discussão na Subcomissão para a elaboração da futura LDB, o constituinte Octávio Elísio os reconhecia como sujeitos da instalação de uma esfera pública voltada a afirmação do direito à escola pública e gratuita em todos os níveis e para todos. Para tanto, dizia ele, seriam imprescindíveis a garantia de direitos constitucionais ao magistério e recursos públicos exclusiva e efetivamente voltados para garantir a liberdade de ensino através da escola pública, gratuita e de boa qualidade para todos.

\section{3 - "Todos somos constituintes" 36}

\section{1 - A educação como questão nacional e democrática}

Historicamente, os esquemas binários - não raro essencialistas - naturalizam a complexidade das relações econômicas, sociais, políticas e culturais de uma sociedade. Ainda que seja difícil imaginar que não se relacionem, mesmo que em

\footnotetext{
36 Título do Boletim do Centro de Estudos e Acompanhamento da Constituinte (CEAC), da Universidade de Brasília (UNB), fundado em 1987 para reunir documentos e promover intercâmbio com centros similares criados por outras universidades, faculdades isoladas, instituições sindicais e culturais.
} 
graus e de formas variadas, economia e sociedade e economia e política acabam, não raro, reduzidas uma à outra, de forma que a esfera pública é apresentada necessariamente em correspondência direta com os interesses privados.

Ao considerar enganoso conceber o Estado como sinônimo de esfera pública, o debate e o conjunto das manifestações realizadas na Subcomissão indicavam dizer respeito ao exercício da cidadania a partir da defesa e da instalação de direitos, ampliando os espaços de diálogo público e transformando características da cultura política no país.

Destacamos um conjunto de manifestações que, por sua condição de representação social ou institucional, pela natureza das formulações e pelas propostas apresentadas, tiveram relevância para a compreensão das rupturas, convergências, continuidades e descontinuidades discursivas. Ao expressarem concepções políticas, tiveram centralidade nos confrontos, pactos, acordos e sínteses que marcaram os trabalhos nos diferentes espaços da Constituinte.

As manifestações ocorridas, representando a pluralidade de experiências, tradições e representações culturais, sociais e institucionais no país, trataram de inúmeras questões e propostas, revelando um conjunto de divergências, convergências, consensos e dissensos relativos: ao conceito de educação; ao direito à educação; ao papel do Estado; à destinação dos recursos públicos e à democratização do acesso; à organização dos sistemas de educação; às definições das competências dos entes federados; à democratização da gestão; e à categoria de qualidade. Estes temas atravessaram a dimensão política de dois eixos interpretativos: a educação como questão nacional e democrática; e a educação frente à antinomia entre o público e o privado, desafiando a pensar a relação entre o movimento interno dos debates na Constituinte e sua importância no contexto em que ocorreram, seja por sua eficácia ao tornarem visíveis determinadas realidades e experiências, seja por explicitarem projetos e visões presentes na sociedade brasileira.

No que se refere à Subcomissão de Educação, Cultura e Esporte, no curso dos dias 23 de abril de 1987 a 30 de maio de 1987, houve cinco audiências públicas, das quais da $12^{\text {a }}$ à 16 $6^{\text {a }}$ foram ouvidas entidades e organizações ligadas à área da Educação, somando 72 pessoas, entre intelectuais, representantes de instituições e 
entidades $^{37}$. Destas, 38 trataram da Educação, e 14 integraram o Fórum Nacional de Educação $^{38}$.

${ }^{37}$ Entidades participantes das audiências e principais pontos defendidos Associação Nacional de Educação (ANDE). Participa das conferências brasileiras de educação. Clama pela universalização do ensino básico. Defende a exclusividade de verbas públicas para a escola pública, é signatária da Carta de Goiânia, fruto da IV Conferência Brasileira de Educação, realizada entre 2 e 5 de setembro de 1986, na cidade de Goiânia, que pontuou vinte e um itens a serem inscritos no texto constitucional consagrando os princípios de direito de todos os cidadãos brasileiros à educação, em todos os graus de ensino e de dever do Estado em promover os meios para garanti-la. Reivindica a elaboração de uma nova lei de diretrizes e bases da educação nacional a partir dos princípios inscritos na Nova Constituição. Associação Nacional de Docentes do Ensino Superior (ANDES). Entidade criada em 1981, luta por uma universidade pública, gratuita, autônoma, crítica, democrática e competente. Defende a isonomia salarial e o provimento de cargos e funções através de concurso público e que a escola privada se mantenha com seus próprios recursos. Considera a educação prioridade nacional. Federação Brasileira de Associações de Professores de Educação Física (FBAPEF). Defende a educação escolar pública, gratuita e laica em todos os estabelecimentos de ensino, tendo a educação física como disciplina obrigatória nos três níveis de ensino e o direito de todo cidadão ao desporto e ao lazer. Associação Nacional dos Profissionais de Administração da Educação (Anpae). Entidade que congrega especialistas, dirigentes escolares e universitários, professores e pesquisadores, fundada em 1961, promove o desenvolvimento da teoria e da prática da Administração da Educação. Integra o Fórum de Entidades de Educação na Constituinte. Posiciona-se pelo reconhecimento do direito à educação gratuita, pública, laica e de qualidade em todos os níveis e modalidades de ensino como um direito de todos os cidadãos brasileiros. Sociedade Brasileira para o Progresso da Ciência (SBPC). É uma sociedade que congrega de nove a dez mil cientistas, estudantes de pós-graduação, pesquisadores e professores universitários, mantém sócios correspondentes fora do país e promove reuniões anuais desde 1948. Defende a autonomia da universidade, o vestibular como a forma mais democrática de acesso à universidade, pois está baseado no mérito, e o concurso público para o ingresso no magistério. Grupo de Trabalho Educação e Constituinte do Ministério de Educação (GT/MEC). Grupo de Trabalho criado no âmbito do Ministério de Educação para subsidiar os trabalhos da Subcomissão e trazer as contribuições das entidades educacionais. Conselho Federal de Educação (CFE). Começou a germinar em 1846, amadureceu no Império e se cristalizou na República. Sr. Fernando Fonseca, presidente do CFE. Fórum Nacional dos Secretários de Educação - Entidade que congrega todos os secretários de educação dos estados brasileiros, conhecido como Consed, Conselho Nacional dos Secretários de Educação. Defende a aposentadoria com proventos integrais aos vinte e cinco anos no magistério e o ensino público, gratuito, laico, mas não ateu. Defende a escolaridade mínima e obrigatória a partir dos seis anos sem estabelecer limites de idade. Sugere a busca de descentralização de responsabilidades para garantir a qualidade do ensino. Defende a co-participação do Estado na educação, uma vez que os municípios não podem arcar sozinhos com a educação de $1^{\circ}$ grau. Confederação dos Professores do Brasil (CPB). É uma entidade civil que congrega trinta e uma entidades do magistério nas unidades da Federação, constituída por professores de $1^{\circ}$ e $2^{\circ}$ graus. Defende o ensino público, gratuito e laico em todos os níveis de escolaridade como direito de todo cidadão brasileiro. Luta pela eleição direta para diretor de escola e pelos princípios básicos das carreiras do magistério público para os diferentes níveis de ensino, assegurando o provimento de cargos e funções mediante concurso público. Sociedade de Estudos e Atividades Filosóficas (Seaf). Defende a volta da filosofia ao ensino de $2^{\circ}$ grau, a reestruturação dos cursos superiores de filosofia e a pesquisa em filosofia. Federação das Associações de Servidores das Universidades Brasileiras (Fasubra). Reúne a categoria dos servidores técnico-administrativos das universidades e congrega cerca de 45 entidades, com cem mil servidores. Defendem o ensino público e gratuito em todos os níveis de ensino. Conselho de Reitores das Universidades Brasileiras (Crub). Entidade que congrega todas as universidades brasileiras, tanto públicas quanto privadas, criada em 1966. União Brasileira dos Estudantes Secundaristas (UBES). Luta pela escola democrática, para garantir o acesso de toda a juventude brasileira à educação, a permanência na escola, a eleição para diretores de escolas e universidades, o direito de organizar-se livremente em grêmios dentro das escolas. Centro de Estudos Educação e Sociedade (CEES). Entidade criada em 1978 para atuar na produção teórica, se posicionar nos movimentos educacionais, atuar no campo da organização educacional comprometida com o ensino público, gratuito, laico e de qualidade. Associação Nacional de Pós-Graduação em Educação (Anped). Esta 
associação reúne pesquisadores e professores de pós-graduação do país, sendo, na época, composta por 33 programas de pós-graduação, alguns centros de pesquisa, praticamente 600 professores, estudantes e pesquisadores de educação. Produziu um documento que serviu de base para a IV Conferência de Educação, realizada em Goiânia, que resultou na Carta de Goiânia, importante documento que subsidiou a luta de várias entidades durante a Constituinte. Centro de Trabalho Indigenista (CTI). Entidade que apoia a causa indígena e que luta pela discriminação histórica contra índios, negros e outros grupos minoritários. UNI - União das Nações Indígenas. Representa os 170 grupos tribais distribuídos pelas diversas regiões do país. Associação Brasileira de Escolas Superiores Católicas (Abesc). Reúne 16 universidades católicas, 32 outras instituições de ensino isoladas, com o total de aproximadamente 200 mil alunos. Campanha Nacional de Escolas da Comunidade (CNEC). É a antiga Campanha Nacional dos Educandários Gratuitos. Nasceu em 1943, no Recife, e atua no meio do povo, na comunidade. Está presente em todos os estados da Federação. Federação Nacional dos Estabelecimentos de Ensino (Fenen). É uma entidade de direito privado, representa 35 mil escolas privadas de todas as formações, origens, tendências, convicções e correntes educacionais. União Nacional dos Estudantes (UNE). Entidade de representação nacional dos estudantes universitários brasileiros, criada em 1937, esteve à frente de inúmeros acontecimentos sociais e políticos relevantes do país, com grande capacidade de mobilização. Associação de Educação Católica do Brasil (AECB). É uma associação presente em todos os estados brasileiros. Existe desde 1945 congregando escolas públicas e particulares, de $1^{\circ}, 2^{\circ}$ e $3^{\circ}$ graus, onde são debatidos temas vinculados à educação a partir dos princípios católicos, em consonância com a CNBB. Federação dos Trabalhadores em Estabelecimentos de Ensino da Região Sul (FETEE-Sul). Federação Interestadual dos Trabalhadores em Estabelecimentos de Ensino (FITEE). É uma entidade sindical que congrega professores e auxiliares de administração escolar, dentre aqueles que não são funcionários públicos, fundada em 1955. É vinculada à Confederação Nacional dos Trabalhadores e Estabelecimentos de Educação e Cultura. Conselho Federal de Farmácia - Reúne as lideranças farmacêuticas do país e busca o desenvolvimento independente, o processo científico, tecnológico e cultural dos alunos de graduação e pós-graduação em farmácia. Centro de Estudos Afro-Brasileiro (Ceab). Entidade dedicada ao estudo da situação do negro no Brasil, trouxe importantes contribuições de ordem didático-pedagógica, com o objetivo de promover uma pedagogia interétnica. Conselho da Comunidade Negra - Criado em 1984 por ação política dos negros do PMDB, no governo Franco Montoro, foi o marco inicial de uma nova forma de atuação no combate ao racismo. Foi a partir do Conselho da Comunidade Negra que começaram a se formar grupos de especialistas que colocaram o seu conhecimento técnico-acadêmico à disposição da causa negra, levando à sensibilização e inclusão de diversas categorias profissionais na questão negra. $\mathrm{Na}$ área de educação, desde os seus primórdios, o Conselho desempenhou relevante papel na mudança da abordagem da educação, especialmente a do ensino fundamental, com reflexos em todo o Brasil. Especialistas que hoje estão na academia defendendo teses, publicando livros e CD-ROMs, começaram esse trabalho no Conselho da Comunidade Negra, que estruturou uma assessoria junto à Secretaria de Educação, transformando São Paulo no primeiro estado brasileiro a ter um livro didático que respeita a população negra e a diversidade de maneira geral. União dos Diretores de Escolas do Magistério Oficial (Udemo). Fundada em 1952 com o objetivo de defender os interesses dos diretores de escolas estaduais do estado de São Paulo. Comissão Pró-Federação de Arte-Educadores. Congrega 28 entidades constituídas de associações, núcleos e grupos de educação artística com o objetivo de firmar o espaço e o valor da arte na educação do povo brasileiro. Associação Nacional dos Professores de Prática de Trabalho - Associação que valoriza a importância da produção no processo da aprendizagem, uma vez que o trabalho constitui elemento fundamental na formação integral do indivíduo. Organização das Cooperativas Brasileiras (OCB). Representa mais de três mil cooperativas atuantes e três milhões e meio de cooperados diretos, respondendo por um grande percentual de produtos, principalmente no setor agrícola, e também de serviços no setor urbano e no meio rural. Estimula o ensino do cooperativismo na escola como forma de desenvolvimento e integração social e econômica. Associação Educativa Evangélica - Reúne instituições da Assembleia de Deus, dos Pentecostais, dos Luteranos, dos Batistas, dos Presbiterianos e dos Metodistas. As instituições evangélicas de educação datam do ano de 1870, no Brasil, e introduziram a co-educação e a prática da educação física nas escolas. Estiveram sempre vinculadas ao ensino privado. Conferência Nacional dos Bispos do Brasil (CNBB). Defende a oferta de ensino religioso. Associação Brasileira de Antropologia. Constituída por professores, pesquisadores e antropólogos. Acompanha as questões das minorias e as questões ligadas à ordem social. Rejeita qualquer forma de censura exercida pelos órgãos de Estado. (Backes; Azevedo; Araújo, 2009, p. 543-64). 
A participação da Associação Nacional de Educação (ANDE) deu-se logo na primeira audiência pública, no dia 23 de abril de 198739, quando, após sua manifestação, entregou a Carta de Goiânia, documento que assumiu o papel de contraponto ao anteprojeto da Comissão Afonso Arinos, conforme analisado no capítulo anterior.

A Associação Nacional dos Docentes do Ensino Superior (ANDES) ${ }^{40}$ apresentou uma Plataforma Educacional à Subcomissão de Educação, Cultura e Esportes. Nela, apontava que:

Originária das grandes mobilizações de trabalhadores do século $X X$, a luta pelo ensino público e gratuito no Brasil representa, com clareza, um exemplo da divergência existente entre os interesses da maioria da população brasileira em obter serviços públicos de boa qualidade e aqueles das classes mais privilegiadas que controlam 0 Estado e suas políticas.

Lutamos por uma educação pública, gratuita, crítica, democrática e competente. Uma luta já antiga e hoje, mais do que nunca, necessária. Uma luta, portanto, para a transformação da realidade que temos entre nós. (ANC, 1988b, p. 70)

A Confederação de Professores do Brasil (CPB), entidade civil que congregava 31 entidades do magistério das unidades da Federação em todo país, foi representada por seu presidente, professor Tomaz Gilian Deluca Wonghon, na $15^{\mathrm{a}}$ reunião, dia 28 de abril.

Ao registrar que os professores de $1^{\circ}$ e $2^{\circ}$ graus estavam organizados na CPB porque estavam impedidos de sindicalização pela Constituição ${ }^{41}$, o presidente

\footnotetext{
${ }^{38}$ As quatorze entidades do Fórum: Associação Nacional de Educação - ANDE; Associação Nacional de Docentes de Ensino Superior (ANDES); Associação Nacional de Profissionais de Administração da Educação (ANPAE); Associação Nacional de Pesquisa e Pós-Graduação em Educação (ANPEd); Confederação dos Professores do Brasil (CPB); Centro de Estudos Educação e Sociedade (CEDES); Central Geral dos Trabalhadores (CGT); Central Única dos Trabalhadores (CUT); Federação das Associações dos Servidores das Universidades Brasileiras (FASUBRA); Ordem dos Advogados do Brasil (OAB); Sociedade Brasileira para o Progresso da Ciência (SBPC); Sociedade de Estudos e Atividades Filosóficos (SEAF); União Brasileira dos Estudantes Secundaristas (UBES) e União Nacional dos Estudantes (UNE).

${ }^{39} \mathrm{Na}$ audiência do dia 23 de abril também fizeram uso da palavra a professora Maria Beatriz Moreira Lucy, presidente da Associação Nacional de Profissionais da Administração da Educação; o professor Luiz Antônio Cunha, representando a Sociedade Brasileira para o progresso da Ciência (SBPC) e Cláudio Boschi, presidente da Federação Brasileira de Associações de Professores de Educação Física (FBAPEF).

${ }^{40}$ A ANDES fazia parte do Fórum Nacional na Constituinte em Defesa da Escola Pública e foi signatária da proposta educacional para a Constituição por ele formulada.

${ }^{41}$ Como afirma Maria Helena Moreira Alves (1984, p. 69), os governos militares se apoiaram na Consolidação das Leis do Trabalho (CLT) para intervir e controlar os sindicatos. Os Atos
} 
saudou os dirigentes sindicais que passaram a ter representação pública no Parlamento, e avaliou a situação do Brasil situando, antes de mais nada, o lugar da Constituição como instrumento de libertação do povo e como instrumento da construção da sociedade sonhada. Deluca Wonghon apontou que 64,7\% da população economicamente ocupada recebiam de um a dois salários, e que, dos $49,6 \%$ da população brasileira com menos de vinte anos, $52 \%$ tinham menos de dois anos de escolaridade, resultado da educação oferecida pelos governos militares.

A valorização da representação política foi retomada, agora não apenas para reforçar a importância de que o Parlamento contasse com representantes oriundos do movimento social. Ao tratar da participação da entidade no Conselho Federal de Educação destacou:

Nós não consideramos que o fato de termos alguns professores de $1^{\circ}, 2^{\circ}$ ou $3^{\circ}$ graus, representando no Conselho Federal, seja uma representação efetiva; para a construção dessa sociedade que nós queremos, queremos também que essa representação seja legítima, que o representado seja identificado com aquele que o representa e vice-versa, que haja essa pujança de representação e exercício da representatividade. (ANC, 1988b, p. 108)

Observe-se que duas concepções são aqui apontadas, ambas contendo o problema da legitimidade da representação. A primeira diz respeito à necessidade de identificação entre representantes e representados, para que as necessidades e interesses possam ter expressão política. A segunda se refere ao estabelecimento de relações sistemáticas entre os que representam e os que são representados, o que daria sentido à representação. Ambas são apresentadas como aspecto desejado na construção da utopia de uma nova sociedade.

Ao discutir as características da representação política, Bobbio (2000, p. 459) demonstrou o caráter ambíguo do conceito de representação, e o caráter genérico do conceito de interesse. Este último poderia comportar tanto o sentido específico de

Institucionais, do no 1 ao no 4, suspenderam os direitos individuais, apoiados na Constituição de 1967, a Lei de Segurança Nacional (Decreto-Lei 314/67) estabeleceu a punição às greves e o impedimento do direito à livre organização, manifestação e expressão, consideradas como ameaça à Segurança Nacional. Estavam instituídos os fundamentos para a censura, para as perseguições, para violenta repressão e condenações políticas. O Ato Institucional ํo 5 , sem prazo de vigência, fechou o Congresso e suspendeu as garantias constitucionais e individuais. A Emenda Constitucional $\mathrm{n}^{\circ}$ 1, de 24.01.1969, incorporou os Atos Institucionais baixados até então, consolidando no plano jurídico o autoritarismo e o arbítrio por parte do Estado. 
interesses parciais, locais, corporativos, fracionais quanto àqueles gerais, nacionais, coletivos e comuns.

A representação política estaria marcada pela mesma ambivalência, podendo ser uma representação política de interesses gerais ou particulares ou de grupos. A doutrina da democracia e do Estado representativo sustentaria a representação política como manifestação de interesses gerais. Ao analisar a polaridade entre a representação política e a representação de interesses, bem como os dilemas enfrentados para definir critérios que estabeleçam o "peso" de cada votante, as conclusões de Kelsen indicam que:

Se na assembleia representativa é a maioria que [...] decide contra a minoria, é muito mais sensato estabelecer um tal parlamento sobre um sistema de nomeação que considere cada eleitor não simplesmente como membro de uma determinada profissão, mas com membro do Estado em seu todo e que o suponha interessado não apenas em questões profissionais, mas, por princípio, em todas as questões que podem constituir objeto de regulamentação por parte do Estado." (Kelsen apud Bobbio, 2000, p.465).

Ora, a oposição entre a representação de interesses, justificaria, antes da formação dos partidos, a existência de mandatos vinculados, que representariam interesses e mandatos livres, voltados à representação geral. Assim, além da questão da soberania, diz respeito aos programas em relação ao Estado e aos destinos da sociedade. Já os partidos, assumiram o lugar de organização e mediação da representação,

[...] dando origem a duas relações distintas, uma entre eleitores e partido, outra entre partido e eleitos, que tornaram cada vez mais evanescente a relação originária e característica do Estado representativo entre mandante e mandatário, ou, hobbesianamente, entre o autor e o ator. (Bobbio, 2000, p. 469-70)

Também se tornariam o lugar de maior poder de decisão, mas relativamente soberanos, uma vez que suas práticas estariam determinadas pela Constituição de um Estado e pela escolha dos eleitores.

Há uma abordagem original na proposição e na experiência comunicada e posta em discussão pelo presidente da CPB, envolvendo muitos dos desafios da participação social na Constituinte e além dela. Ao instaurar o debate sobre temas gerais e nacionais, há um deslocamento do monopólio dos partidos no tratamento 
desses temas. A comunicação do presidente demonstra que estava em curso - na entidade e nos espaços de organização comum compartilhados com outras entidades - em particular no Fórum Nacional em Defesa da Escola Pública, um processo de ressignificação da participação, da representação, do poder e da soberania interna e externa do país, à luz das formulações e experiências de reorganização das entidades no contexto da transição democrática.

Além das questões de representação postas em relação ao Conselho Federal de Educação, órgão de formulação e normatização do Sistema Nacional de Educação (Brasil,1961), outras duas proposições foram apresentadas no sentido de redefinição, ampliação e fortalecimento das práticas democráticas. A primeira referiu-se à eleição de diretores porque "a comunidade escolar onde a escola está inserida tem a responsabilidade, e mais que isso, tem o direito de discutir, gerir os destinos dessa escola [...]". (ANC, 1988b, p. 108) A proposição de que a gestão da unidade escolar, e, portanto, da política educacional em seu âmbito, não fosse determinada apenas pelas estruturas do Estado e do governo estabelecia uma nova mediação no processo democrático, a saber: a de que os programas, planos e ações de governo não bastariam para que a política educacional assegurasse o direito à Educação. Quanto à segunda proposição, se referia ao fato de que a comunidade escolar, onde estivesse inserida a escola, além da gestão, deveria estar envolvida na discussão do planejamento do ensino.

A proposta de eleição do gestor, de participação na gestão e no planejamento educacional de cada unidade educacional pela chamada comunidade escolar - isto é, os setores envolvidos diretamente na vida da escola: professores, estudantes, funcionários e pais ou responsáveis - pretendia fortalecer o espaço público, tendo como elementos comuns e comunicáveis a garantia do direito à Educação e a expressão das expectativas sociais e culturais, assim como o domínio sobre as políticas e as práticas do Estado, ampliando o círculo público de formulação da política educacional e de sua concretização. Estas premissas permitiriam uma educação democrática, para o que concorreriam a liberdade de expressão e 0 respeito aos direitos humanos, direitos estes que prenunciariam o futuro, na medida em que deveriam estar a serviço de uma sociedade justa e livre.

O exercício da liberdade "não como atributo da vontade, mas sim um acessório do fazer e do agir” (Arendt, 2007, p. 213) estaria a serviço da constituição 
de direitos não apenas pela existência de espaços de reconhecimento de sua não existência, de reivindicação, de denúncia sobre as desigualdades e assimetrias sociais, mas porque a palavra

[...] individual ou coletiva, que diz o justo e o injusto, é também a palavra pela qual os sujeitos que a pronunciam se nomeiam e se declaram como iguais, igualdade que não existe na realidade dos fatos, mas que se apresenta como uma exigência de equivalência na sua capacidade de interlocução pública... (Telles, 1996, p. 5)

O registro da manifestação da CPB colocava o problema da participação dos segmentos educacionais em termos de formulação, elaboração e decisão da política educacional, tornando os sujeitos visíveis e reconhecíveis em termos culturais, sociais e cognitivos. Esta aparição social ensejaria a interlocução sobre a natureza e o sentido das decisões e dos parâmetros de execução das políticas públicas. Convergindo no que se refere à participação, a União Brasileira de Estudantes Secundaristas (UBES), manifestando-se por meio de seu presidente Rovílson Robbi Brito, destacou a necessidade do direito à livre organização no interior das escolas, uma conquista, à época, recente, que se constituiria em fato primordial para que o "estudante fosse ativo no processo educacional". Propôs também a eleição, pela respectiva comunidade educacional, da direção e coordenação das instituições de ensino e pesquisa em todos os níveis.

Marcando a diferença de interesses, o Presidente da União dos Diretores de Escolas do Magistério Oficial (UDEMO), Francisco Antônio Poli, manifestando a convicção da entidade sobre um processo constituinte que trouxesse justiça social, sobretudo na área da Educação, afirmou:

Quero deixar bem claro que a nossa presença aqui se prende única e exclusivamente a um fato, o fato de acreditamos numa Constituição que vá trazer justiça social para este País, e que isso se faça, principalmente na área da Educação (ANC, 1988b, p.224)

Contudo, em relação à gestão democrática da Educação, ele se colocou contrário à eleição de diretores, considerando um grande avanço a situação de São Paulo, em que os cargos de diretores seriam providos por meio de concursos públicos de provas e títulos. O concurso se constituiria em uma espécie de antídoto que evitaria "os problemas de política, com ' $p$ ' minúsculo, que poderíamos chamar de politiqueiros. Para evitar que apenas grupos monopolizem direções de escolas, 
direções de instâncias de educação" (Ibidem). A manifestação a esse respeito restringiu-se a um temor projetivo da proposta de eleição de diretores, a ela associando imagens de apropriação privada da esfera pública deslocadas de qualquer pensamento ou formulação crítica sobre a proposta.

Menos confiante quanto aos destinos da Constituinte, manifestou-se a Federação de Sindicatos de Trabalhadores Técnico-Administrativos em Instituições de Ensino Superior Públicas do Brasil (Fasubra) - representando 45 entidades das Universidades Federais, com cerca de cem mil servidores a ela filiados - acerca da democracia, expressando direta e claramente as dúvidas da entidade quanto à eficácia da Constituinte para que se "alcançasse a educação desejada e a felicidade do povo". (Ibidem, p. 109). Destacando o papel do movimento sindical e popular para a formação da consciência democrática no Brasil, o diretor da Fasubra, José Ferreira de Alencar afirmou:

[...] a verdadeira consciência democrática do País parte do movimento sindical brasileiro, parte das comunidades de associações de bairro, deveria, portanto, se prever na Constituição o apoio à entidade, porque é ela que tem dado consciência ao trabalhador brasileiro do que ele é. Ele vai aprender lá exatamente o que é contrário aos interesses dele. (Ibidem)

Esta perspectiva foi reforçada pelo documento entregue pela Fasubra à Subcomissão de Educação, Cultura e Esportes que destacou a natureza da Constituinte e suas limitações:

Neste momento em que se volta à discussão da elaboração de uma Nova Carta Constitucional, antes de analisarmos a questão específica da Educação, é importante ressaltar certas limitações específicas que se acenam em termos da Assembléia Constituinte recentemente eleita. Dentre estas limitações destacamos algumas: 0 fato de termos uma Assembleia Constituinte Congressual retira-nos a possibilidade de termos uma Constituinte livre, soberana e exclusiva; as forças mais reacionárias do País patrocinaram e até elegeram candidatos comprometidos com a política autoritária do regime militar; um enorme número de políticos, alguns até congressistas, comprometidos com os interesses do setor privado da economia faz parte de uma verdadeira articulação lobby nacional em defesa do ensino privado no País. Existem outras limitações de caráter mais profundo de ordem política, entre outras a chamada "abertura política" bem como a "transição democrática" que são as pressões de um processo em que as frações dominantes procuram substituir a forma com que conduzem a organização da sociedade. (Ibidem, p. 149) 
Ao longo do debate ocorrido durante a reunião da Subcomissão, uma nova manifestação teria lugar, tornando clara a desconfiança sobre a possibilidade de uma constituinte resolver os problemas dos trabalhadores, em função dos limites estabelecidos pela natureza da chamada transição democrática. O discurso do dirigente da Fasubra assumiu, assim, o tom de autodefesa e autoproteção. Ao reconhecer a invisibilidade dos movimentos do poder e dos interesses privados, preferiu legitimar-se como dirigente da entidade e de seus representados, afirmando suas propostas com certo distanciamento frente ao processo constituinte. Em suas próprias palavras:

Para finalizar, eu diria apenas o seguinte. Há companheiros aqui, trabalhadores, servidores de universidades, e há uma lenda africana que diz: em determinado momento o macaquinho fez amizade com o peixe, e começam a dialogar. O peixe aceitou o diálogo, e foi tudo muito bem. Mas, um dia, houve uma enchente muito grande e o macaquinho, preocupado, tirou o peixe para ele não se afogar, e o levou para as árvores - e o peixe morreu. Claro! Ele só poderia viver na água. Para nós trabalhadores, não temos ilusão: nossas águas é a organização e a consciência do trabalhador; não é a Constituinte; não é aqui que vamos encontrar.

Pode ser que o Brasil seja, mais uma vez, uma particularidade, mas, geralmente, a história dos povos é a seguinte: primeiro muda, depois vem uma Constituição. Nunca a Constituição mudou aquilo que o povo está esperando, e, nós, trabalhadores da Fasubra, temos essa posição. Como peixinhos não enxotamos o diálogo; fomos chamados, e aqui estamos. E toda vez que a Fasubra for convidada, apesar de ela ter uma visão muito clara do trabalhador, ela virá aqui, dirá sua opinião, e dirá também, às vezes, até da sua surpresa por ser convidada e das dúvidas que tem quanto a se saber se este é o caminho para resolver os problemas dos trabalhadores. Isto, para nossa posição não ficar duvidosa, e depois virem a perguntar: o que o Alencar estava fazendo lá? Estávamos propondo, inclusive, aquilo de que temos dúvida. (Ibidem, p. 127)

O documento apresentado pela Fasubra discorria sobre os movimentos das frações das classes dominantes no sentido de conquistar a direção intelectual e moral do conjunto da sociedade, para o que seria necessário ampliar o espaço político, visando a ampliar a legitimidade da dominação. Para a Fasubra, a forma de dominação repressiva era substituída pelo esforço de construção da hegemonia das classes dominantes.

A declaração de distância em relação aos donos do poder, e a afirmação de que a Constituinte "não seria o lugar" dos trabalhadores das Universidades Federais, legitimamente lançava dúvidas e questionamentos sobre todo o processo mas, por 
outro lado, criava uma espécie de cilada interna ao discurso, que o fazia perder potência e força no embate político, de vez que diminuía a possibilidade de desconstituição de outros discursos e práticas comprometidos com a redução de direitos universais em benefício de interesses privados, no próprio momento de seu transcurso, instituindo outras possibilidades e deslocando para outro tempo, o futuro, e para um lugar incerto o processo de transformação social desejada. Seja como for, o documento da Fasubra apontava a necessidade de mobilização de toda a sociedade para a conquista da democratização do país e para o acesso de todos, em igualdade de condições, à saúde, à educação e ao trabalho.

Ainda na sessão de trabalho de 28 de abril de 1987, manifestou-se o Centro de Estudos Educação e Sociedade (CEES) ${ }^{42}$, explicitando o lugar dos sujeitos nos debates da Constituinte. O CEES apresentou-se como força disposta a interferir no processo de decisão. Assim se manifestou a professora Elizabeth Camargo:

Quero chamar a atenção, com toda a polidez, desta Subcomissão que respeito muito, e dos Constituintes presentes, dizendo que é preciso que S. Ex. ${ }^{a}$ S pensem muito, pois sabemos que não dá para lutar facilmente contra os lobbies privatistas. Eles não aparecem, assim de público, como nós, mas temos uma luta que vem dos renovadores, e quando se fala até parece que estou vendo palavras da Revolução Francesa, quando se fala em escola pública, no ensino laico, ensino de qualidade [...]

[...] apesar de saber que a nossa mobilização vai muito além desta, quero declarar, em nome do CEES, uma entidade que surgiu em 1978, num momento difícil, tentando atuar ao nível da produção teórica, se posicionar nos movimentos educacionais, atuar na organização do campo educacional [...] temos que conseguir colocar marcos muito claros e realmente que revelem o nosso comprometimento com o ensino público, gratuito, laico e de qualidade.

Então, acho que os Constituintes que quiserem votar, realmente, em benefício da maioria da população brasileira, vão contar conosco. E nós estaremos aqui, certamente em caravanas muito grandes, assistindo a essa votação e observando, depois de 20 anos, quem está colocando o interesse público e coletivo acima dos interesses

\footnotetext{
42 O Centro de Estudos Educação e Sociedade surgiu em março de 1979, em campinas (sp), como resultado da atuação de alguns educadores preocupados com a reflexão e a ação ligadas às relações da educação com a sociedade. A partir de sua criação, o CEES passou a editar a revista Educação \& Sociedade, e atualmente edita também os Cadernos CEES. A ideia primeira de criação do centro, assim como o primeiro número da revista, surgiu durante o I Seminário de Educação Brasileira, realizado em 1978, na Unicamp. a partir do II Seminário de Educação Brasileira, o CEES passou a organizar, conjuntamente com a Anped e ANDE, as Conferências Brasileiras de Educação (CBEs). Além destes eventos, o centro participou de inúmeros movimentos sociais de reorganização do sistema educacional, congressos, encontros, seminários, assim como esteve presente no fórum nacional de educação na constituinte e do fórum nacional em defesa da escola pública.
} 
pessoais. Quero dizer que a entidade da qual faço parte é uma entidade que respeita os políticos, mas que sabe também fazer política [...] também fazemos política, embora não sejamos parlamentares, e que o bom parlamentar tem que ouvir o movimento social e nós fazemos parte deste. (Ibidem, p. 134)

Desta manifestação destacam-se três questões importantes. A primeira, a busca para tornar visível a "invisibilidade" dos setores privatistas na Constituinte, indicando e contribuindo para que o conflito aparecesse e fosse identificado no espaço público e comum. (Arendt, 2014, p. 64) A segunda é a defesa da escola pública, laica e de qualidade, mobilizando para isso o imaginário da Revolução Francesa e a dimensão histórica da construção dos direitos. Já a terceira diz respeito à advertência aos Constituintes sobre a observação e o controle social exercido pela entidade, no que respeita a uma possível defesa da prevalência dos interesses privados sobre os públicos.

As afirmações tornam inequívoca a intenção de ocupar lugar no espaço público, exigir reconhecimento dessa condição e tornar públicas e inteligíveis as proposições para o país. A matriz dessa condição é o suposto de que a ação política não é e não deve ser monopólio dos partidos e dos parlamentares. O espaço público comum estaria reafirmado na declaração que iguala os sujeitos no direito de pensar e agir. O fazer política não deveria ser atribuição de poucos, sustentado pelo discurso competente que gera a incompetência social (Chauí, 2013c).

Por outro lado, a natureza e a direção, da manifestação de Gilda Poli Loures, representante do Conselho Nacional de Secretários de Educação ${ }^{43}$, quanto à representação e a democracia, apresentava um sentido diverso. Ao esclarecer que o Conselho representaria o Governo (em verdade os governos), destacou os pontos de convergência com outras entidades, distinguindo-as:

[...] o Conselho de Secretários de Educação que representa o Governo e, no entanto, as suas posições coincidem em muitos pontos, em quase todos, com as representações da sociedade civil que hoje pela manhã fizeram as suas apresentações. Vou me ater, especificamente, nesses pontos, porque eu considero isto vital para os constituintes sentirem como a Nação está pensando sobre a educação. Este documento é fruto de um Governo que assumiu quando ainda tínhamos no Brasil uma ditadura e o compromisso do

\footnotetext{
${ }^{43}$ O Conselho Nacional de Secretários de Educação (Consed), foi criado em setembro de 1986, é uma associação de direito privado, sem fins lucrativos, que congrega, por intermédio de seus titulares, as Secretarias de Educação dos estados e do Distrito Federal.
} 
Governo Central não era absolutamente com o povo. Por isso, conseguimos aglutinar-nos, secretários de educação dos mais diferentes partidos políticos, porque o nosso compromisso era um só, com o povo, e era preciso [que] puxássemos o carro-chefe da democratização deste País, que passava necessariamente pela educação. (ANC, 1988b, p. 79)

Este texto é transparentemente claro, apresentando de novo as noções de nação e povo no debate, na tentativa de homogeneizar ideias e significados, legitimar posições e conviç̧ões. Os pressupostos que teriam levado às identificações políticas e discursivas e aos possíveis consensos não foram revelados, o que os tornava harmoniosamente coincidentes e, por isso, instrumentos de poder na batalha das categorias em curso no debate.

Ora, a não explicitação dos fundamentos é o que sustenta a operação ideológica que permite afirmar que só o compromisso com o povo, aqui entendido como cidadãos integrados e soberanos, teria permitido a aglutinação dos partidos. Isto equivale a dizer que, ao revés, seria exatamente isso o que define os partidos (seus programas, formas de organização e história), que teriam sido deixados de lado para levar a efeito a democratização, tendo a Educação - por razões indecifráveis - se tornado seu carro-chefe.

A mesma operação aproxima nação e educação, diferenciando-a dos políticos, para supostamente construir um lugar de poder e força para as propostas coincidentes sob as definições de povo e nação, mantida a ambiguidade semântica nada casual, uma vez inerente às naturezas e funções destas noções.

\section{2 - A educação e a cultura como centro da questão nacional democrática}

Quatro discursos de entidades não ligadas diretamente à atividade educacional trouxeram percepções distintas sobre o papel social da Educação como instrumento de acesso à cultura. $\mathrm{O}$ Centro de Trabalho Indigenista, representado pela professora Marina Kanh Villas Boas, manifestaria sua posição mobilizando outras imagens e significados presentes no país e na cultura e atribuindo significado à educação. Ponderava: 
Antes de tudo, queremos formar nossas vozes na defesa de uma educação pública gratuita e de boa qualidade para todos os brasileiros.

Assim sendo, ao darmos sugestões para o texto constitucional, enfatizamos a questão da educação escolar indígena, dentro da problemática mais abrangente da educação, referente a toda população brasileira, notadamente dos grupos sociais mais estigmatizados e alijados do centro de tomada de decisões do poder e dos benefícios daí decorrentes. Neste contexto, inserem-se os povos indígenas do Brasil. Defendemos, assim, uma educação que garanta a consolidação de um espaço democrático a todos os brasileiros, rompendo, desta forma, com a discriminação que historicamente vem atingindo índios, negros e outros grupos sociais minoritários, que são, na verdade, os que compõem a grande maioria da população brasileira. Sobretudo queremos fazer realçar no texto constitucional 0 respeito às diversidades e às especificidades culturais de um País pluriétnico e plurilíngue como o Brasil. Atualmente, sabemos estar registradas no País cerca de 200 línguas, sendo que aproximadamente 170 são indígenas, e 30 de origem europeia, asiática e africana. (Ibidem, p. 167)

A perspectiva de uma educação democrática seria ainda mais explicitada quando a representante do Centro de Trabalho Indigenista criticou a política oficial voltada à homogeneização cultural, isto é, ter-se assumido que apenas uma língua seria falada em todo o território. O silêncio que fez ocultar a realidade cultural, também por meio da Educação, teria limitado "a plena revitalização da identidade dos indivíduos e grupos sociais existentes no País. No caso dos povos indígenas, essa omissão resultou na destruição, lenta e decisiva, de uma grande parte de seu patrimônio sociocultural". (Ibidem)

A fala de Marina Kanh Villas Boas desvela uma narrativa que envolve a construção da identidade nacional associada à recusa da alteridade como prática política do Estado Brasileiro, particularmente no período ditatorial. Em nome da identidade una e indivisa da nação, ao tempo em que se negavam direitos, a expressão social, a memória e a capilarização da violência. Esta declaração nos remete à conferência de Ernest Renan, realizada na Sorbonne em 1882, que, marcada por um conjunto de ambiguidades, até porque um referente único e compacto do termo nação não existe e, talvez por isso mesmo, afirmou que a "essência de uma nação está em que todos os indivíduos tenham muito em comum, e também que todos tenham esquecido muitas coisas". (Renan, 1997, p. 162). Na conferência $O$ que é uma Nação? destacou: 
O esquecimento, e mesmo o erro histórico, são um fator essencial na criação de uma nação, e é por isso que frequentemente o progresso dos estudos históricos representa um perigo para a ideia de nação. De fato, a investigação histórica traz de volta à luz os atos de violência que ocorreram à origem de todas as formações políticas, mesmo daquelas cujas consequências foram as mais benéficas (Ibidem, p.161).

As palavras de Villas Boas deram início à proposta de um processo molecular de mudanças, rompendo a perspectiva de um progresso difuso que encobre a violência e afirmando o direito às identidades culturais das comunidades indígenas e ao direito de conhecê-las, uma vez inscritas na história do País. A proposta apresentada pela União das Nações Indígenas (UNI), Centro de Trabalho Indigenista ( $\mathrm{CTI})$, Comissão Pró-Índio (CPI); Conselho Indigenista Missionário (CIMI), Operação Anchieta (OPAN); Associação Brasileira de Antropologia (ABA) e Associação Brasileira de Linguística (ABRALIN) previam em seu artigo 1ํ:

O Brasil é um País pluriétnico e plurilíngue.

$\S 1^{\circ}$ É vedada toda forma de racismo e discriminação social, cultural e linguística no processo educacional.

$\S 2^{\circ}$ A educação é diferenciada, considerada a diversidade étnica e linguística do País,

$\S 3^{\circ}$ É garantida às minorias linguísticas autóctones escolarização em língua portuguesa e em língua materna.

Art. $2^{\circ}$ Todos os brasileiros têm direito à educação pública, gratuita em todos os níveis, independentemente da raça, sexo, idade, língua, credo religioso ou convicções políticas.

Parágrafo único. É garantido, através da educação, o acesso aos conhecimentos locais, regionais e universais, atendendo-se aos interesses de cada comunidade em particular e do País em geral. (ANC, 1988b, p. 194)

Mais do que a não discriminação, estava em questão o direito ao conhecimento da produção cultural local e regional em relação aos conhecimentos considerados universais.

Outro assunto que se colocou na agenda constava do documento elaborado a partir do II Encontro do Grupo de Estudo sobre a Educação Indígena, coordenado por UNI e CIMI, que denunciava as políticas contra os índios em função das omissões da FUNAl. Aos olhos das entidades, os problemas não estavam relacionados apenas às limitações e faltas do Estado brasileiro: poucos recursos e mau funcionamento das instituições. Lido no anverso é possível considerar que não 
se tratava de uma falta, antes de uma presença: "uma política indigenista orientada para integração à sociedade envolvente, integração esta entendida como um processo de substituição gradativa da cultura indígena pela chamada cultura nacional" (Ibidem, p. 195). O documento reafirmava o direito dos povos indígenas a uma educação específica que oferecesse respostas aos processos culturais que viviam, denunciando a negação desse direito pelos sistemas coloniais e neocoloniais.

Assinalou-se ainda que a conduta do Estado onipresente confundia o dever em relação à educação com o direito de impor um único tipo de ensino e um único tipo de escola. (Ibidem, p. 195-6). Com efeito:

Deve-se tomar por base, portanto, para a elaboração de um texto constitucional, os princípios da garantia e do respeito às especificidades culturais que caracterizam e constituem os diferentes grupos sociais brasileiros. Muitos deles são portadores e produtores de culturas originais e valiosas na composição da cultura brasileira, que deverão, portanto, estar evidenciadas, referidas e fortalecidas pelo sistema educacional. Este não pode ser concebido simplesmente como um conjunto de práticas pedagógicas, e sim como uma das várias dimensões da cultura de um país. É o espaço onde se permite a recriação e a transmissão de um conjunto de saberes, técnicas e valores históricos socialmente produzidos. (Ibidem, p. 167)

Não se pode perder de vista que este discurso se fundava no reconhecimento das especificidades culturais constitutivas dos diferentes grupos sociais. 0 reconhecimento da condição de alteridade deveria fundamentar as ações do sistema educacional, que teria como papel recriar e difundir as várias dimensões da cultura do país.

Esta abordagem superava as visões que restringiam a função social da Educação à esfera da simples reprodução de conhecimentos e, por conseguinte, da eficácia didática. O problema epistemológico neste caso é o de que à Educação não cabe apenas a reprodução de conhecimentos e informações, de maneira exterior ao sujeito, e que ensinar, em sentido amplo, "não é transferir conhecimento, mas criar as possibilidades para a sua produção ou sua construção" (Freire, 2011, p.25) o que implica a consideração dos sujeitos que conhecem e, por evidente, de sua experiência cultural e social: 
A educação como prática da liberdade, ao contrário daquela que é prática da dominação, implica a negação do homem abstrato, isolado, solto, desligado do mundo, assim como também a negação do mundo como uma realidade ausente dos homens. (Idem, 2007, p.81).

A perspectiva dialógica aqui indicada seria retomada por Ailton Krenak, representante da União das Nações Indígenas. Reconhecendo o momento de participação na Subcomissão de Educação como oportunidade rara de manifestação e de aparição social, o representante apontaria que as políticas educacionais no Brasil teriam dificuldades em reconhecer e considerar a cultura e a tradição dos povos indígenas. Disse:

Quando se pensa em texto constitucional, é muito importante lembrar, é muito importante resgatar o dever, o respeito que o estado nacional deve para com as minorias, para com os grupos tribais ainda existentes no Brasil hoje. Somos 170 grupos tribais vivendo nas regiões mais diversas do Território Nacional. Algumas dessas pequenas tribos somam 50, 60 indivíduos, mas são esses 50, 60 indivíduos que se expressam num idioma, numa língua única, que compreendem a realidade do mundo, têm uma leitura da sua história, em particular, e da história da humanidade que é muito particular e vinculada diretamente à sua tradição oral. A maioria desses pequenos grupos tribais explica a existência do mundo, explica a sua própria existência, situa-se diante do mundo, diante das pessoas europeias que vieram para o Brasil, diante das pessoas negras, diante das pessoas asiáticas; elaboram dentro do seu idioma um universo de significação para explicar a existência de vocês também. E a partir dessa possibilidade, a partir dessa condição de origem do pensamento, de origem de uma visão que está ligada à criação do mundo, é importante ressaltar, não se permita mais o atropelo, a descaracterização, a violência contra nossa tradição, contra nossa possibilidade de continuar falando um idioma que não foi escrito por nenhuma pessoa, um idioma que não foi elaborado por nenhum pensador de línguas, mas que foi aprendido de Deus. Cada um dos nossos grupos recebeu um idioma de Deus. O ancestral deu uma língua para cada um de nós, ensinou que cada grupo falasse a sua língua, ensinou que cada grupo se distinguisse do conjunto dos outros seres que existem no planeta, que vivem no mundo, e que elaborasse, a partir daí o seu universo, sua explicação do mundo. (ANC, 1988b, p. 171)

Ao situar e enunciar demandas do Estado-Nação quanto às suas finalidades, garantia dos direitos das minorias, dimensão ética e respeito pela existência das minorias, o discurso contrasta com a narrativa sobre a nação que pretende homogeneizar a sociedade, torná-la una e indivisa, ocultando suas contradições e antinomias, condição da universalização de interesses particulares. 
Ao avesso do discurso ideológico cativo do silêncio, o discurso da União das Nações Indígenas trazia ao espaço público não apenas necessidades, mas sua cosmovisão que, construída a partir dos diferentes idiomas, configurava diferentes identidades indígenas. Comunicando-a no espaço público, eles pareciam dar sentido à realidade do mundo, fazendo ouvir o que ouviam, fazendo ver o que viam. Estava constituindo um espaço de domínio público, tal qual concebeu Hannah Arendt: "É a publicidade do domínio público que pode absorver e fazer brilhar por séculos tudo o que os homens venham a querer preservar da ruína natural do tempo". (Arendt, 2014, p.68). Assim, esta participação no espaço da Constituinte mostrava-se mais como afirmação do direito à existência social destas nações no interior da nação do que como oportunidade de expressão de reivindicações. Krenak prosseguiu:

Talvez eu esteja falando com os senhores numa linguagem muito imprecisa, muito religiosa para um pensamento crítico e técnico especializado sobre a questão de educação, mas o que diz respeito às populações indígenas, hoje mesmo, é a questão da possibilidade de sobreviver o pensamento original do povo indígena [...]

Acredito que poucos conjuntos de pessoas, poucos grupos sociais que existem no mundo hoje têm a segurança de dizer que conhecem a história do seu povo desde o dia em que o seu ancestral mais antigo criou o seu povo e existiu. Um povo que tem a memória do nascimento dos rios e das montanhas, um povo que tem a memória do nascimento de cada um dos bichos que existem, e se essa memória é a afirmação desse povo como ser humano, afirmação como pessoa capaz de criar, capaz de enriquecer a experiência humana, acredito que os senhores hão de concordar que é fundamental que isso seja respeitado, que é fundamental que isso seja, se possível, fortalecido, porque é desta maneira que a Nação brasileira vai refletir um conjunto de cores, de riquezas, de pensamentos, e não uma coisa de uma nota só. Se a cultura brasileira for uma coisa de uma nota só, a cultura brasileira está perdida. Se a cultura brasileira for capaz de expressar a riqueza, a pluralidade, a diversidade que existe hoje, se for capaz de contemplar, poderemos ser uma Nação de muito pensamento bom, de onde uma produção de conhecimento muito rico poderá vir a colaborar no conjunto da Humanidade, para nos colocar como pessoas plenas. (ANC, 1988b, 171-2).

Ao fazer a defesa do direito à memória como componente da identidade cultural dos povos indígenas, o apelo ético, reiterado pela valorização de suas experiências e tradições, mostra-se como alicerce de uma nação plural cuja marca civilizatória viria a ser a plenitude humana. Estava em questão "a validade de outros universos culturais, cognitivos e valorativos", rompendo "a unanimidade construída em torno das concepções convencionais de nação e território, progresso e 
desenvolvimento, tradição e modernidade". (Telles, 1996, p. 6) A partir dessa perspectiva abriu-se espaço para outro tema polêmico, o da desigualdade racial no Brasil, tendo como central um tópico negligenciado: a Educação. Wladimir de Souza, representante do Centro de Estudos Afro-Brasileiros, estabelecendo clara relação entre garantia de direitos e democracia, afirmou:

O Estado brasileiro nunca cumpriu a sua função constitucional de educar, de dar uma condição digna à população como um todo. Parece-me que a mentalidade que o colonizador impingiu na consciência nacional, a partir da chamada consciência intelectual, e que se voltou para o culto de si mesma e não para o culto do homem, como o seu conjunto, que é a beleza de uma Nação, haja vista que o orçamento da União, antes da emenda comum, era $2 \%$, e nós propomos que o orçamento da União seja, pelo menos, de $40 \%$ no período de formação de uma geração. Aprendemos na ideia quilombista que o uso do solo e do subsolo é para que o cidadão ao nascer, tenha garantida a condição de se alimentar, de ter a instrução básica, de se profissionalizar e de contribuir com a Nação. Um brasileiro mal educado, mal alimentado não pode ser cidadão [...] (ANC, 1988b, p. 226-7)

A garantia de direitos como obrigação do Estado constitui um campo de referências que reconfigura a relação com a nação. São os direitos que definem o lugar dos sujeitos que deixam de estar encapsulados nas noções de elite e povo. Tornando pública certa compreensão da história do país, e relacionando colonização, consciência nacional e dos intelectuais brasileiros, o representante do Centro de Estudos Afro-Brasileiros denuncia o descompromisso do Estado e das universidades com o conjunto dos seres humanos que constituem a nação, em particular com as desigualdades sociais que tinham na cor um dos seus principais aspectos explicativos. No contexto de movimentos sociais em prol da cidadania, defendeu que $40 \%$ do orçamento da União, durante vinte e cinco anos, fossem destinados à educação e à cultura, esta como algo relacional envolvendo "sujeitos em relação de poder" (Clifford, 1986, p. 15). "Não creio que haja democracia - isso é ilusão - sem a instrução necessária, coletiva do País." (ANC, 1988b, p. 227) A Educação é vista como uma possibilidade de qualificar a participação e a representação.

O Presidente do Conselho da Comunidade Negra, Hélio Santos, reforçou esta consideração ao apontar a necessidade de se identificar a cara da Nação e de se 
discutir o que ensinar, pois, na escola, se edificariam as pessoas. Assim se manifesta:

Os juristas nos ensinam que a Constituição deve ter a cara da Nação. Essa expressão é muito inteligente, é uma figura correta. Mas, nunca se discute [...].

Dois terços da população brasileira têm menos de trinta anos. Pouco mais da metade da população, deste País, é do sexo feminino. E segundo o IBGE, 44\% da população brasileira não é branca. Se nós tentarmos desenhar essa cara ela terá que ser uma cara marcadamente feminina, jovem e não branca, necessariamente. Acho que cabe exatamente à educação esse papel. (Ibidem)

Ao defender a tese do aumento de investimentos o representante do Centro de Estudos Afro-Brasileiros não considerou factível a destinação de $40 \%$ do orçamento da União, se levadas em conta as necessidades de outros setores, em especial da saúde. A ênfase de sua fala estava na proposta de democratização em todos os níveis e da negação da discriminação de qualquer tipo. Aqui estava em jogo a própria explicação da questão da desigualdade racial no Brasil, sustentada pela ideia de que, se os afro-brasileiros adquirissem outros níveis de educação e renda, teriam iguais oportunidades de avanço social (Lovell, 1995).

Entendemos também que a educação é inseparável dos princípios de igualdade entre o homem e a mulher. É fundamental que o artigo que cuida da educação não diga apenas que a educação é um direito do cidadão e um dever do Estado; é necessário afirmar que a educação tem como base o repúdio à discriminação de qualquer natureza. (ANC, 1988b, p. 227)

Explicitando "o direito de toda a coletividade à educação" o representante destacou a necessidade de que as universidades estivessem envolvidas com a solução dos problemas nacionais. Ele considerou que a pesquisa realizada na universidade pública estava apartada dos problemas da sociedade, como a miséria e a marginalidade social. O Presidente do Conselho da Comunidade Negra retomaria o problema dos direitos humanos e da igualdade, alargando-o, mobilizando conceitos hierarquizadores das capacidades humanas, o que permitiu apontar a necessidade de que a Educação se constituísse em espaço de inclusão para construção do país. "A escola, de fato, deve estar igualmente voltada para potencializar o infradotado, porque este tem energia natural de construir este País e 
de legar este País para o rumo que deve ir." (Ibidem). Seja como for, para a entidade tratava-se da inclusão das maiorias como condição do alcance de outro futuro.

Outra entidade não ligada diretamente à Educação, que realizou uma significativa manifestação, foi a Confederação Nacional da Associação dos Moradores (CONAM), que agregava treze mil Associações de Moradores de bairros, vilas, favelas, mocambos e conjuntos habitacionais em todo o território nacional e 20 federações estaduais. De princípio, a CONAM apontou o valor da possibilidade de manifestação do povo e de suas entidades, anunciando a importância da Constituinte e da nova Constituição para a democratização do país.

A política educacional foi considerada elitista e alienante, e os governantes, pela prerrogativa de defini-la, responsabilizados por uma educação não comprometida com a realidade nacional e os interesses do povo. Aos olhos da entidade, este quadro seria resultante das opções do modelo de desenvolvimento econômico e social adotado pelos que assumiram cargos de mando no país desde a ditadura.

Ao fazer a defesa do ensino público, laico e gratuito em todos os níveis, a entidade, por meio de um texto, fez também uma apreciação da situação do país e defendeu seu projeto político em declarada oposição àquele encetado pelos militares. Cito:

Nós não temos dúvidas. O que está em jogo aqui é se nós queremos um Brasil dependente, subjugado aos interesses do capital financeiro internacional, das empresas multinacionais que violam os direitos dos nossos trabalhadores, espoliam as nossas riquezas naturais e saqueiam a nossa economia, subordinados aos interesses dos banqueiros e grande burguesia industrial nacional monopolista - que é associada aos interesses estrangeiros assim como aos interesses daqueles que detêm o monopólio da propriedade da terra, os latifundiários. Sob o guarda-chuva dos militares que ainda hoje tutelam o governo. Ou se nós queremos um Brasil livre das peias do militarismo, verdadeiramente autônomo e independente das grandes potências estrangeiras, com uma economia voltada para satisfazer prioritariamente as necessidades do fortalecimento e expansão do mercado de consumo interno, com relações de produção moderna e estáveis no campo e na cidade, reconhecendo-se os direitos sociais dos trabalhadores. Que se faça respeitar no conceito das nações civilizadas, como nação livre e soberana, centro irradiador de progresso econômico, social, político e cultural, para o bem-estar da humanidade. (Ibidem, p. 389) 
Apontando para a necessidade de soberania externa a partir da soberania interna, apoiada em uma economia movida pelo mercado interno e por relações de trabalho modernas e estáveis que suporiam o reconhecimento dos direitos sociais dos trabalhadores, a entidade pretendia demonstrar que sua proposta não tinha como referência única o interesse privado como condição para o desenvolvimento do país e, ainda, que a proposta de interferência na realidade vislumbrava um novo homem e uma nova sociedade.

A entidade apontou como elementos de avaliação da situação educacional a existência de 19 milhões de analfabetos adultos, $26 \%$ do total da população; mais da metade das crianças matriculadas na primeira série do $1^{\circ}$ grau que não chegariam à segunda série; professores mal remunerados; e gastos militares maiores do que os com educação.

A ambiguidade das noções de nação e povo e a condição intercambiável dos significados tornam-se aqui evidentes. A educação pública gratuita e universal seria direito dos filhos dos camponeses e operários, "que produzem a riqueza sem dela usufruir", ao mesmo tempo, em que formadores de "nosso caráter enquanto nação", ideologia que contribuiu para a imagem de uma nação totalizada, fruto da mistura das raças, que conviveriam em harmonia, em um território determinado, com sua língua ${ }^{44}$, crenças religiosas, folclore e costumes, expressões culturais que definiriam uma unidade social imaginária. ${ }^{45}$

A educação deveria ser reconhecida, por um lado, como direito daqueles que experimentaram a realidade da exclusão e, de outro, como sedimento de um caráter nacional fabulado e, por esta condição, integrante do imaginário social. O texto da entidade afirmava que a ausência de oportunidades para os trabalhadores sustentaria a continuidade do círculo vicioso da pobreza funcional e aos interesses do bloco econômico e social defendido pelos militares. Reconhecendo o Fórum da

\footnotetext{
${ }^{44}$ Hobsbawm (2013, p.155-8) demonstrou que a unidade linguística foi um dos elementos fundantes da formação do Estado-Nação. A educação foi um meio fundamental para a universalização da língua, escrita e falada, da cultura e de valores morais. Entre 1840 e 1880 a população da Europa cresceu $33 \%$, mas o número de seus filhos na escola cresceu $145 \%$.

${ }^{45}$ Marilena Chauí (2013a, p.163-66) diferenciou o caráter nacional da chamada identidade nacional. A ideologia do caráter nacional operaria com o pleno ou o completo, e a segunda com a falta, a privação e o desvio. No caso do Brasil, os outros seriam os países capitalistas desenvolvidos tomados como unidades plenamente realizadas, já o País estaria identificado pelo subdesenvolvimento e, portanto, uma identidade lacunar, marcada por privações, sem a plenitude imaginada pela ideologia do caráter nacional.
} 
Educação em Defesa do Ensino Público como espaço de organização relevante para o debate, reafirmava a proposta do Fórum, sem prejuízo daquelas formuladas pelo próprio movimento em encontros realizados (ANC, 1988b, p. 400-2).

Outro grupo, o dos seringueiros, representado pelo Conselho Nacional dos Seringueiros, se manifestou trazendo para o espaço público uma leitura particular da situação da Amazônia. O Secretário Nacional do Conselho, Osmarino Amâncio Rodrigues, representando meio milhão de trabalhadores do setor trouxe a público um documento aprovado no I Encontro Nacional dos Seringueiros da Amazônia ${ }^{46}$, realizado em outubro de 1985, em que tratava da relação entre educação, cultura e desenvolvimento da região.

O Conselho apontou a exigência de uma política de desenvolvimento que atendesse aos interesses dos seringueiros e não privilegiasse as grandes empresas. Sob esse prisma, situou o lugar da tecnologia considerada bem-vinda, desde que não em detrimento dos saberes, da cultura e do modo de vida dos habitantes da floresta amazônica. Este querer social implicava que os projetos e planos educacionais incluíssem a preservação das matas ocupadas e exploradas pelos seringueiros.

A partir de tais fundamentos, foi apresentado um conjunto de propostas articuladas entre si, que previam o direito de todos os seringueiros ao estudo, com a garantia de escolas em todos os lugares, para todas as idades, com qualquer número de alunos, preocupações que se justificavam também em função das grandes distâncias a serem percorridas por terra ou pelos rios. Sugeriu que os professores fossem seringueiros escolhidos pela comunidade, mas ao mesmo tempo indicava que o Ministério da Educação, junto com as Secretarias Estaduais e o Ministério da Cultura, deveriam cuidar da educação na Amazônia, sobretudo nos seringais, assegurando aos professores remuneração e treinamento adequados.

Diferentes dimensões da experiência e da produção cultural seriam valorizadas, começando pela merenda, que deveria incluir produtos locais como a castanha e outros gêneros alimentícios produzidos nos estados da Amazônia. Indicava, ainda, a necessidade de divulgar para o País, histórias, poesias, músicas,

\footnotetext{
${ }^{46}$ De acordo com a manifestação do secretário nacional do Conselho Nacional dos Seringueiros, o Encontro ocorreu entre 11 e 17 de outubro de 1985, com seringueiros dos estados de Rondônia, Acre, Amazonas e Pará, reunidos em Brasília. (ANC, 1988b, p. 403)
} 
receitas e objetos fabricados pelos seringueiros, apoio aos projetos como 0 "Seringueiro do Acre", e que os chamados treinamentos dos professores levassem em conta a cultura popular.

Hoje, nós não temos mais o direito, nem a liberdade de ter certeza que vamos continuar ali, dada a invasão do latifundiário, do fazendeiro. Eles estão expulsando a nós seringueiros, tanto para as periferias da cidade, como para o outro lado, no território boliviano. Dentro desse quadro, de cinco anos para cá surgiu o movimento sindical que nos deu oportunidade de começarmos a nos juntar e discutir o nosso destino. Isso veio nos dar condições de nós nos organizarmos. Hoje estamos fazendo um trabalho para tentar garantir a nossa permanência e, também, trazer de volta os companheiros que foram expulsos. Mesmo sabendo que não vamos poder trazer todos.

Em cima disso, começamos a pensar na criação da escola, a luta pela escola. Hoje no município de Xapuri, no Acre, tem oito escolas criadas pelos seringueiros através do Projeto Seringueiro.

Nesse projeto, o seringueiro constrói a escola, o seringueiro é quem é o professor de outro companheiro seu. Isso devido justamente nós acharmos que é possível nós, os seringueiros, sermos professor, sermos agente de saúde - outro trabalho que estamos fazendo lá, construindo postos de saúde. A partir do ano de 1986, a Secretaria de Educação e Cultura do Acre começou a pagar os professores seringueiros dessas escolas.

Porque o que se viu no passado foi sempre que o seringueiro - mais ou menos o mesmo caso dos que estão nas periferias das cidades sempre foi considerado "um pessoal que não sabe fazer nada"! E todo mundo sabe fazer as coisas, desde que haja oportunidade. (Ibidem, p. 431)

Parte desse processo envolveu a criação da Cartilha Poronga e a participação no Projeto Interação ${ }^{47}$. Mas a separação entre os Ministérios da Cultura e da Educação dificultou o aporte de recursos e a continuidade dos projetos. "Nós, seringueiros, achamos que os dois Ministérios devem trabalhar juntos, porque a educação não vive sem a cultura". (Ibidem)

O Conselho Nacional dos Seringueiros comunicou e apresentou ao país a violência a que esta parcela da população estava submetida. Malgrado essa

47 Trata-se de material utilizado no Projeto Seringueiro, conforme explicado pelo representante do Conselho Nacional dos Seringueiros,: "O material didático do Projeto Seringueiro é um material mesmo nosso, da nossa cultura. Nós achamos que não valia a pena para nós estudarmos ou ensinarmos os nossos companheiros com um material da cidade, que não tem a ver com a nossa realidade de lá. Em cima disso, foi criada a Cartilha Poronga, com a participação dos seringueiros, do Centro de Documentação e Pesquisa da Amazônia (Cedop/Acre) - que hoje não existe mais Assessoria do Centro de Documentação e Informação - Cedi/São Paulo e apoio financeiro do Projeto Interação do Ministério da Cultura". (ACN, 1987, p.431). 
condição, formulou e trouxe à esfera pública um conjunto de propostas que, além de contribuir para desconstituir as triviais e costumeiras imagens de atraso destas regiões do país, fez conhecer a experiência social e cultural dessas comunidades. Importa saber que este foi o sentido da apresentação do Pai Nosso dos seringueiros: ${ }^{48}$

Tanta coisa da borracha que não sei explicar não. Encontrei pedaço dela na panela de pressão (Bis). Vamos dar valor ao seringueiro, vamos dar valor a esta Nação, pois é bom o trabalho desse povo que faz pneu de carro e pneu de avião (Bis).

Fizeram a sandalinha, fizeram o chinelão, inventaram a botina, que a cobra não morde, não. Tanta coisa da borracha que não sei explicar, não. Encontrei pedaço dela na panela de pressão. (Bis). (Ibidem, p. 432)

As concepções sobre nação enquanto totalidade indivisível e povo, de um lado como total dos cidadãos integrados e soberanos e de outro como reserva dos excluídos, dos miseráveis, dos necessitados, indelevelmente impressas no imaginário dos autores do discurso, tem como núcleo as ideias de valorização e visibilidade do trabalho. Trata-se de uma batalha política travada também por meio das palavras e das metáforas, buscando o reconhecimento do direito e da condição de pertencimento ao país. Uma narrativa que pretende tornar a cultura e as distintas experiências sociais dos povos da floresta um desafio à interpretação e compreensão. Vale seguir a declaração final de Osmarino:

[...] Fiz todo um esforço de ficar aqui, porque, para onde eu vou, vou ter que caminhar seis dias a pé e tem companheiros seringueiros que, para chegar à capital ou no local do seu município, ele caminha até um mês para chegar às cidades. Então, aí está a questão na Amazônia que muitos não conhecem. E digo que quem não conhece a Amazônia não conhece o Brasil.

Quando se discute uma Constituição, devem-se levar em consideração os brasileiros, os trabalhadores do Brasil e muitas vezes, esquece, inclusive os Estados Unidos que já tem sua constituição feita. (Ibidem)

Notadamente, trata-se de outra apropriação das imagens do território, associando-as à experiência do trabalho. Osmarino, longe de se identificar com as

\footnotetext{
${ }^{48}$ Pai nosso do seringueiro: "Seringueira que estas na selva, multiplicados sejam os vossos dias. Venha a nós o vosso leite e seja feita a nossa borracha assim na prensa como na caixa. O sustento da nossa família nos daí hoje e todos os dias. Perdoai nossa ingratidão, assim como perdoamos a maldade do patrão. Ajudai-nos a nos defender das garras do regatão. Amém." (ANC, 1987, p.397)
} 
imagens de uma "natureza selvagem, com territórios incultos, fronteiras da civilização" (Murari, 2009, p.16) apresenta como desiderato a ampliação do campo de visão sobre a Amazônia, colocando-a no centro das imagens da vida dos trabalhadores. Como se vê, está em questão a expressão da soberania do País, tomando-se em consideração as experiências, reivindicações e direitos dos trabalhadores. Desafio específico e distinto de outro estado nacional, os Estados Unidos, já detentor de sua constituição.

\section{3 - Os sentidos da participação}

O discurso criava, assim, uma ruptura com a visão defendida e difundida pelos militares à frente do Estado brasileiro, de que os EUA representavam um ideal de nação a ser perseguido. Para os constituintes, era reafirmada, em termos políticos, a soberania como questão incontornável. Progressivamente se rompe a impermeabilidade dos regimes políticos brasileiros à presença dos homens comuns na política.

No dia 18 de maio de 1987, duas outras participações tratariam da relação entre educação, como questão nacional, e democracia. A primeira, do professor Moacir Gadotti, que identificava a participação da sociedade civil no processo da Constituinte como fonte de maior legitimidade para o texto constitucional, ao mesmo tempo em que constava a ampliação das responsabilidades dos constituintes na sua elaboração, além da delegação conferida pelos mandatos, pois implicava compromisso com a consecução das leis. Realizando a crítica aos processos autoritários da elaboração destas considerou que o texto constitucional só se tornaria exequível mediante a participação e pressão da sociedade. No caso da Educação, indicava a necessidade de que os educadores se sentissem comprometidos com o texto final, para o que a participação na constituinte já estaria sendo fundamental. Neste sentido, destacou três dimensões da participação:

Outro ponto em que tenho alguma convicção - que submeto realmente à discussão são verdades, talvez fruto da experiência - é que nenhum projeto pedagógico, por melhor que seja, tem condições de ser implantado, se aqueles aos quais ele se dirige não tiveram uma ativa participação na decisão política. A questão da participação nas decisões, através de Conselhos Populares de Educação, por 
exemplo - não sei de poderíamos dizer que Anísio também sonhava com a ideia de um Conselho Municipal de Educação, que não fosse um Conselho nomeado a partir do poder político local ou localista, mas a partir da representatividade que esse Conselho teria na comunidade - seria uma ideia necessária, digamos, para que as comunidades se sentissem responsáveis por seu plano educativo a partir do local. Então que o Plano Nacional de Educação seja fruto desse intenso debate, que esta Constituinte se realize em todas as salas de aulas, que esse debate que estamos tendo agora se realize em todas as escolas com a mesma responsabilidade. (ANC, 1988b, p. 486)

Moacir Gadotti apontou que a implantação de um projeto pedagógico não dependeria apenas de suas características e qualidade, mas da participação dos sujeitos dessa ação, isto é, dos educandos. Gadotti colocava o problema do acesso ao conhecimento de forma similar a Paulo Freire. Ao indicar que a ação pedagógica deveria supor os alunos como sujeitos, apontava para a superação da chamada "pedagogia bancária", que transforma os educandos "em recipientes, quase coisas", a partir de uma concepção mecânica da consciência, que a veria como algo vazio a ser preenchido, alienando-os ou mantendo-os alienados (Freire, 2007, p. 75-8).

Ora, a abordagem de Gadotti trazia um problema central da epistemologia de Paulo Freire, qual seja, o de que, ao se instalar o processo educativo, ambos, educadores e educandos, devem e podem se tornar sujeitos, a partir do estabelecimento de uma relação dialógica em que o ato de conhecer se identifica com a instauração da própria liberdade. Neste caso, a relação pretende superar a de que educador, detentores do saber, depositam informações em educandos passivos cabendo-Ihes, nesta condição, memorizar o conteúdo narrado. A questão posta em relação à liberdade se estende à discussão acerca da representação política, pois a proposição realizada indica que setores antes não representados, em função da força dos poderes locais, deveriam poder se fazer representar nos Conselhos Municipais de Educação.

Outra dimensão da participação seriam os Conselhos Populares de Educação. Ainda que não tenha explicitado sua compreensão acerca de tais Conselhos, é possível capturar a preocupação de Gadotti com a participação dos vários segmentos que fazem parte das unidades educacionais. Ao antever a normatização pela Carta Constitucional, do Plano Nacional de Educação, tal qual 
previsto em 1946, indicou a necessidade de que este fosse fruto também de intenso debate social.

Ainda em relação à participação, Gadotti destacou a importância de que o debate sobre as propostas para a Constituinte chegasse às escolas, ampliando o diálogo sobre direitos, justiça e políticas públicas, permitindo que um setor expressivo da sociedade se apropriasse de informações e da natureza do debate e das proposições. Como perspectiva, a questão central seria a de tornar popular a escola pública no que toca à sua gestão e aos conteúdos que deveriam ter relação com as necessidades dos alunos. Contrapondo-se à criação de escolas paralelas mais avançadas, a ênfase no discurso recai sobre a democratização da educação pública em seu conjunto.

Outra análise, a de Paulo Freire, apresentava a questão da consciência social e da política como instrumento de transformação social. Freire concluiu sua fala na Subcomissão relatando o testemunho de um menino no Primeiro Tribunal do Menor, em Teresina, no Piauí.

[...] Houve um deles, de uns 13 anos, que contou a história de um de seus companheiros que morreram no Ceasa porque o corpo não aguentou o peso que era obrigado a carregar com um saco de batatas. Era tão grande o peso, a desproporção era tão enorme com relação à competência física, que a criança morreu. E ele contou essa história, assim como contou a história de amigos mortos pela Polícia. Em certo momento ele parou, olhou e disse: e dizem que somos o futuro do País, mas nós não "tem" nem presente [...]

Um outro menino, fazendo também suas denúncias, perguntou: será que pensam que nós "trabalha" morrendo porque "gosta"? Será que pensam que nós não "vai" "prá" escola porque "é" preguiçoso, porque não "quer" estudar? Não. Nós "trabalha" morrendo para os meninos dos ricos "chupar pirulito [...]

Mas isso é verdade, Senador, isso não é demagogia daqueles guris, isso não é demagogia de comunista, de extremista, não. É a história presente deste País. $\mathrm{E}$ os meninos falaram, inclusive, muito em vocês todos na Constituinte, e gritavam que esperavam que fizessem alguma coisa por esses meninos esmagados. Realmente essa é a realidade brasileira. Agora, esse não é um fenômeno a ser resolvido pela pedagogia, mas pela política. É a decisão política, é exatamente a decisão política, que faz a pedagogia entrar. E educação não decide. Como ato político ela precisa de um ato político que decida o seu uso, o seu emprego. Evidentemente que podemos fazer na sociedade civil milhares de coisas, eu faço, todo mundo faz [...] Agora, o que é preciso é fiscalizar o uso desse negócio que você fez, para saber como é que estão chegando essas verbas. 
Bem, meus amigos, vou parar por aqui, porque sei que vocês têm muito que trabalhar, e eu quero, de qualquer maneira, agradecer enormemente a forma como nos receberam. É claro, já passou toda essa fase, pelo menos de estarem recebendo pessoas, mas estou absolutamente disposto, como brasileiro, a fazer o que puder dando a minha contribuição, não há dúvida nenhuma, isto é tarefa de nós todos.

Desejo felicitá-los também pela luta que estão travando e pedir que lutem mais. (ANC, 1988b, p. 488)

Ao ter relatado os dois casos, além de violência, Paulo Freire tratou do exercício da consciência como exercício de liberdade. Mostrou os meninos se reconhecendo a si próprios como objetos de violência e exploração em função das diferenças sociais. Prosseguindo, Freire deixa claro que o reconhecimento da experiência convergia para o sentido da pedagogia, de acordo com a qual é necessária uma permanente atitude crítica para a prática da liberdade.

Uma das grandes, se não a maior, tragédia do homem moderno, está em que é hoje dominado pela força dos mitos e comandado pela publicidade organizada, ideológica ou não, e por isso vem renunciando cada vez, sem o saber, à sua capacidade de decidir. Vem sendo expulso da órbita das decisões. As tarefas de seu tempo não são captadas pelo homem simples, mas a ele apresentadas por uma "elite" que as interpreta e lhas entrega em forma de receita, de prescrição a ser seguida. $E$, quando julga que se salva seguindo as prescrições, afoga-se no anonimato nivelador da massificação, sem esperança e sem fé, domesticado e acomodado: já não é sujeito. Rebaixa-se a puro objeto. Coisifica-se.

- Libertou-se - diz Fromm - dos vínculos exteriores que o impediam de trabalhar e pensar de acordo com o que havia considerado adequado. Agora - continua - seria livre de atuar segundo sua própria vontade, se soubesse o que quer, pensa e sente. Mas não sabe. Ajusta-se [...]. (Freire, 2000, p. 51-52)

A educação como prática da liberdade, expressão que dá nome a um livro do autor, concebida como experiência de problematização dos homens em sua relação com o mundo, se configurava como uma das faces da luta pela humanização e transformação social. A outra, determinante, era a política. Colocando-se na condição de educador, como um dos sujeitos da ação social, depositava sua expectativa de mudança da realidade na ação política enquanto espaço de decisão, avaliação e controle público.

Mais: se, como disse Hannah Arendt (2007, p. 194), o sentido da política é a liberdade e seu domínio de experiência, a ação, o espaço da Constituinte era o lugar 
para pedir aos deputados que lutassem mais. Decisões justas, buscando a efetiva construção de direitos era o que pedia Freire, a começar pela defesa da vida. Com efeito, o que estava em questão, como problema da modernidade, era saber se política e preservação da vida seriam conciliáveis. (Idem, 1993, p.118)

A manifestação dos representantes das entidades e dos intelectuais, e suas propostas de ampliação e/ou aperfeiçoamento da democracia, o tornavam sujeitos de um complexo debate sobre justiça e igualdade, cujo confronto principal delineouse em torno da relação do Estado com a esfera pública e a privada na educação, mais precisamente em torno da destinação dos fundos públicos. 


\title{
4 - Entre o público e o privado
}

\section{1 - Educação, justiça social e igualdade}

A Associação Nacional de Educação (ANDE) iniciou sua manifestação na Subcomissão de Educação, Cultura e Esporte no dia 23 de abril, na $12^{\text {a }}$ reunião ordinária da Subcomissão de Educação, Cultura e Esporte apresentando a Carta de Goiânia como produto das Conferências Brasileiras de Educação. A professora Elba Siqueira de Sá Barreto, de pronto, apresentou o posicionamento da entidade:

\begin{abstract}
A Ande, juntamente com mais duas entidades, o Centro de Estudos Educação e Sociedade (CEDES) e a Associação Nacional de PósGraduação e Pesquisa em Educação (ANPED), realizam as Conferências Brasileiras de Educação e, nesse sentido, nós temos um documento comum que é a Carta de Goiânia, com a proposta publicada a respeito de nossas sugestões para a Constituição que gostaríamos de deixar aqui aos Constituintes. E dentro dos princípios da Carta de Goiânia a ANDE também faz parte do Fórum de Entidades de Educação, que congrega uma série de entidades nacionais, e está defendendo a proposta de verbas exclusivamente para a escola pública, e do apoio dos poderes públicos à escola pública.
\end{abstract}

Dentro de nossos princípios gerais, gostaríamos de destacar na reunião de hoje a questão do descompromisso dos poderes públicos com a educação neste País, que é histórico, e, em especial, com as camadas majoritárias da população. Nós sabemos que os recursos da educação, historicamente, têm sido escassos e, sobretudo, preservados e canalizados para atender às demandas das classes média e alta. (ANC, 1988b, p. 45).

Ao apontar a iníqua distribuição de renda da oitava economia do mundo, Sá Barreto denunciava a existência de 30 milhões de analfabetos jovens e adultos e afirmava a premente necessidade de universalização do ensino básico como parte do direito da maioria da população à escola pública.

Outro representante da ANDE, o professor Jarbas Novelino Barato, tratou de dois pontos. Destacando que o debate se referia à garantia de direitos e não a favores do Estado, como poderiam indicar futuras campanhas políticas, propunha que a Educação de Jovens e Adultos (EJA) não fosse aligeirada, apenas assegurando algumas habilidades de uso imediato. A EJA deveria ser abordada 
como parte das políticas do Estado para garantir a educação dos cidadãos jovens e adultos, não devendo ser oferecida por meio de campanhas ou ações assistenciais.

A democratização da educação pública não deveria, contudo, se restringir ao acesso à escola, inclusive para os que a ela não tiveram acesso em idade própria. Tratar-se-ia de assegurar o acesso ao patrimônio cultural comum "com relação ao domínio da língua nacional, com relação aos conhecimentos no campo das Ciências Sociais, das Ciências Físicas, da Matemática, etc.”. (ANC, 1988, p. 46). A fala do professor Jarbas Novelino indica aspectos do sentido e da função social da Educação, indicando-a como meio de acesso à cultura. O direito se funda nessa premissa essencial que orienta a perspectiva de democratização do acesso à escola.

Nesta mesma reunião da Subcomissão de Educação, Cultura e Esportes, manifestou-se o presidente da Associação Nacional de Docentes do Ensino Superior (ANDES), professor Newton Lima Neto, que destacou:

\begin{abstract}
Em primeiro lugar, nós entendemos que a educação é um direito de todo cidadão, sendo dever do Estado oferecer ensino público gratuito e laico para todos e em todos os níveis. Isso não significa a extinção da escola particular, evidentemente, mas significa que cabe ao Estado, em função do recolhimento de impostos gerados pelo trabalho e pela riqueza desta Nação, devolver à população brasileira, na forma do benefício social da educação, em todos os níveis, o ensino de qualidade laico e gratuito. (ANC, 1988, p.51)
\end{abstract}

Ao ressaltar a necessidade de garantia do direito à Educação como decorrência da sustentação do Estado por meio dos impostos, a ANDES afirmou que, a partir das discussões realizadas pela entidade, tinha condições de demonstrar que a Constituição em vigor à época permitia a destinação de recursos públicos às mantenedoras das escolas particulares, a saber: subsídios fiscais, pequenos valores de dotações diretas e, sobretudo, programas específicos de apoio indireto, de compra de equipamentos, de computadores, de montagem de laboratórios, sendo que o Estado faria o papel das mantenedoras.

A professora Miriam Limoeiro, também da direção da ANDES, destacaria a necessidade de que fosse estabelecido no país um padrão de qualidade para as Instituições de Ensino Superior. O documento apresentado pela ANDES, intitulado "Plataforma Educacional para a Constituição", indicava, no caput do item 124, que 
as escolas particulares deveriam também estar submetidas a esta definição e, ainda, no parágrafo 1ำ que deveria ser garantida a participação de professores e funcionários nos órgãos deliberativos, cabendo ao Estado à observância das normas e condições de funcionamento das instituições privadas. O referido documento apontava, no parágrafo $3^{\circ}$ do item 1.2.4, que deveriam ficar proibidas isenções tributárias às mantenedoras e aos proprietários de empresas particulares de ensino. (Ibidem, p. 70-2)

Com a Carta de Goiânia, a ANDES defendia a vinculação de recursos para a Educação, sendo nunca menos de $13 \%$ da receita tributária para a União e nunca menos que 25\% para Estados e Municípios, e que as verbas públicas fossem destinadas exclusivamente às escolas públicas criadas e mantidas pela União, Estados e Municípios.

Observe-se que a entidade não tratou apenas de aspectos relativos ao financiamento, estrutura e funcionamento do ensino no Brasil, mas, já no início, o documento também apresentava uma concepção de educação:

A educação que queremos não se reduz apenas à transmissão de conhecimentos, mas conjuga saber crítico e compromisso social.

Volta-se, acima de tudo, para o desenvolvimento da capacidade de pensar, de refletir, de julgar. Propõe-se a conseguir estabelecer a relação com a própria realidade, rompendo com os mecanismos sutis da dominação ideológica, desenvolvendo ao mesmo tempo e no mesmo movimento o conhecimento, a consciência crítica e a capacitação à vida e ao trabalho em nossa realidade social. Esta concepção de educação pretende criar e desenvolver as oportunidades facilitadoras da formação da consciência social crítica.

Entendemos a educação como uma das formas, e a escola como um dos lugares, do desenvolvimento da capacidade crítica, cujo campo próprio, bem o sabemos, é a luta, são os enfrentamentos concretos da prática cotidiana, que desenvolvem a crítica, tanto mais quanto mais globais e organizados politicamente forem aquela luta e aquele enfrentamento.

Pela própria natureza da educação que propomos, são pontos inegociáveis e que devem pautar sua organização concreta: a democracia, a qualidade, a gratuidade, o interesse público e a autonomia. (Ibidem, p. 71)

A Plataforma, indicando com clareza a constituição do pensamento crítico como indissociável do processo de domínio do conhecimento, se ocupou da relação com a realidade, apontando como orientação a capacitação dos estudantes para a 
vida e para o trabalho. A perspectiva epistemológica enunciada constituiu-se no substrato da inter-relação proposta entre democracia, qualidade, autonomia e interesse público como princípios norteadores da Educação enquanto direito social. A ANDES indicou ainda, como formulação:

1.2.11 - As instituições de Ensino Superior terão plenamente garantidas a sua autonomia pedagógica, científica e administrativa em relação ao Estado ou entidades mantenedoras que garantirão os recursos financeiros, a seu pleno funcionamento, respeitadas as condições dos artigos anteriores;

1.2.12 - As Instituições de Ensino Superior brasileiras serão necessariamente orientadas pelo princípio da indissociabilidade de ensino, pesquisa e extensão;

1.2.16 - As normas mínimas ordenadoras da estrutura nacional de ensino serão definidas por um organismo colegiado superior de educação, que deverá ter caráter público, total autonomia do Estado e constituição democrática;

$\S 1^{\circ}$ Ao colegiado do caput estará ligado um organismo colegiado específico denominado Conselho Interuniversitário, que deve ter caráter público e permanente, completa autonomia do Estado, tendo entre suas atribuições, a definição de normas mínimas ordenadoras da estrutura nacional de Ensino Superior. (ANC, 1988, p.71)

$\mathrm{Na}$ mesma reunião da Subcomissão manifestou-se a Sociedade Brasileira para o Progresso da Ciência (SBPC). Seu representante, o professor Luiz Antônio Cunha, indicando como vergonhosa a situação cultural e educacional do País e defendendo como primeira proposta os recursos públicos para o ensino público, afirmou:

A situação brasileira em matéria de ensino é das mais deploráveis em toda a América. Se, em nosso País, temos razões para nos orgulharmos de uma série de situações e atividades, de realizações - uma delas é a Assembléia Nacional Constituinte que ora se desenvolve - temos vergonha, as pessoas conscientes dos problemas deste País, das situações terríveis a que está submetido nosso povo, têm vergonha da situação da educação e cultura em nosso País.

Esta constatação, este brado, trago não como um produto exclusivamente pessoal, mas da entidade que represento neste momento [...]. É uma sociedade que congrega 9 a 10 mil cientistas, estudantes de pós-graduação, principalmente pesquisadores e professores universitários de todo o País, mantendo sócios correspondentes fora do Brasil, que desenvolve reuniões anuais desde 1948; que constitui na verdade a Universidade brasileira [...].

Esta indignação da Sociedade Brasileira para o Progresso da Ciência fez com que reconhecesse a procedência das reivindicações do 
movimento de educadores, que se desenvolve por alguns anos em nosso País, no sentido da defesa da destinação exclusiva de recursos públicos para o ensino público, na defesa de uma recuperação da qualidade que o ensino público já teve neste País e que perdeu. (Ibidem, p. 60)

O presidente da SBPC fez referência ao fato de que $25 \%$ da população de quinze anos se encontravam em situação de analfabetismo, enquanto na Argentina, no Uruguai e no Chile isso seria da ordem de $6 \%$. Apontou também que, apesar de a escolaridade obrigatória ser de oito anos, a escolaridade média seria de dois anos, sendo que na zona rural a escolaridade mediana seria de zero ano, o que significaria dizer que metade da população teria escolaridade zero, isto é, nenhum ano de escolaridade.

Em relação ao Ensino Superior, a análise evidencia que a oferta era pequena e de baixa qualidade. Das 80 universidades do País, apenas 20 delas poderiam ser consideradas de boa qualidade. Tais indicadores se constituiriam na evidência da pobreza educacional e cultural do País. Considerando que, em face das desigualdades sociais, a educação estaria representando uma possibilidade de acesso à cultura no Brasil, disse o presidente da SBPC:

A experiência histórica nos mostra que neste País atrasado, que há muito consegue ultrapassar o limiar mais baixo do subdesenvolvimento e da miséria, é o ensino público que tem conseguido responder às demandas da população brasileira em termos de acesso à cultura, em termos da produção de Ciência e Tecnologia. Mas, a experiência histórica, Srs. Constituintes, mostranos que neste País vivemos, nos últimos vinte anos, o resultado de uma política deliberada de privatização do ensino dos que fizeram o golpe de 1964, é possível nomeá-los e, se for instado a isso, o farei. (Ibidem, p. 61)

O professor Luiz Antônio Cunha indicou a presença majoritária, quando não exclusiva, dos proprietários dos estabelecimentos de ensino nos Conselhos Federal e Estaduais de Educação, e uma política deliberada e quase orquestrada, de destruição sistemática e geral do ensino público, em benefício dos setores privados. A propósito, as entidades integrantes do Fórum, ao se posicionarem contra a transferência de recursos públicos para instituições privadas, compartilhavam da mesma percepção.

Substantivamente, os governos militares ampliaram as fontes de financiamento para educação em função da expansão da escolaridade obrigatória 
no País para oito anos, conforme previsto na Lei 5.692 (Art. 1 e 18). Para levar a efeito esta tarefa, criaram-se fontes adicionais de financiamento, e buscou-se racionalizar os gastos e a oferta educacional lançando mão da capacidade de atendimento instalada nas redes pública e privada. Além das receitas de impostos sob o controle da União, os estados e municípios tinham a obrigação de investir $20 \%$ de sua receita na expansão e manutenção de sua rede própria de escolas. Adicionalmente, foi criado o Salário-Educação, o Fundo Especial da Loteria Federal, dos quais $20 \%$ seriam destinados ao Fundo Nacional de Desenvolvimento da Educação $(\mathrm{FNDE})^{49}$. Também comporiam as receitas do FNDE $30 \%$ da receita líquida da Loteria Esportiva, neste caso, vinculada ao Movimento Brasileiro de Alfabetização (Mobral).

A destinação de tais recursos supunha investimento nas redes públicas e na rede privada, tendo como pavimento as definições das constituições de 1967 e 1969. A Constituição de 1967, no parágrafo $2^{\circ}$ do artigo 168, previa: "Respeitadas as disposições legais, o ensino é livre à iniciativa particular, a qual merecerá o amparo técnico e financeiro dos Poderes Públicos, inclusive bolsas de estudo".

Por sua vez, a Constituição de 1969 manteria praticamente a mesma redação cuja perspectiva seria desenvolvida na Lei 5.692. O artigo 41 da Lei afirmaria que

a Educação constitui dever da União, dos Estados, do Distrito Federal, dos Territórios, dos Municípios, das empresas, da família e da comunidade em geral, que entrosarão recursos e esforços para promovê-la e incentivá-la. (Brasil, 1971)

Ora, o ensino sendo livre à iniciativa privada, conforme previa o artigo 42 da Lei, poderia contar com recursos públicos conforme definição do artigo 45:

As instituições de ensino mantidas pela iniciativa particular merecerão amparo técnico e financeiro do Poder Público, quando suas condições de funcionamento forem julgadas satisfatórias pelos órgãos de fiscalização, e a suplementação de seus recursos se revelarem mais econômica para o atendimento do objetivo. (Ibidem)

${ }^{49}$ O Fundo Nacional de Desenvolvimento da Educação foi criado pela Lei 5.537 de 21 de novembro de 1968. O Fundo seria administrado por um conselho deliberativo que previa a participação de membros do governo e representantes do magistério, dos estudantes e do empresariado, no entanto, entre 1968 e 1985, dentre os representantes apenas os empresários participaram (Cunha, 2012, p. 329) 
Completava essa política de racionalização da oferta de vagas e fortalecimento do ensino privado, o estabelecimento de critérios para bolsas de estudo no ensino de primeiro grau, as quais deveriam ser deferidas apenas quando não houvesse vaga em estabelecimento oficial que permitisse ao aluno frequentar a escola com assiduidade. Anos depois, Luiz Antônio Cunha demonstrou que, desde 1968, visando a aproveitar a capacidade instalada nos estados, as orientações dos governos foram no sentido de que os Planos Estaduais de Educação só previssem a criação de equipamentos públicos quando a escola particular não pudesse fazê-lo. (Cunha, 2012, p.334)

Aparentemente paradoxais, as orientações permitiam que o planejamento da política educacional passasse a igualar o público e o privado, emergindo como ponto de diferenciação entre eles os custos para o Estado e o fortalecimento dos negócios, sem que qualquer distinção entre os objetivos educacionais fosse considerada. Em 1987, a participação privada na oferta de vagas do ensino de primeiro grau era de $13,2 \%$, em função dos investimentos públicos na ampliação do atendimento. Nos outros níveis, a participação privada era maior: na pré-escola, 34\%, e no segundo grau, $35 \%$.

Pode-se afirmar que até a crise econômica de 1973, a política educacional induziu a prosperidade do setor privado na área educacional, pois tanto as condições de ascensão das classes médias quanto as bolsas de estudo permitiam o pagamento das mensalidades e, por conseguinte, que a obtenção de lucros sustentasse um processo de concentração de capital que facilitou a extensão das atividades educacionais nas instituições, abarcando, muitas vezes, do primeiro grau até o superior.

O aumento da inflação, no contexto da crise de 1973 - quando foi quadruplicado o preço do petróleo - que durou mais de dez anos, foi o responsável pela mudança desse quadro. A crise teve como foco o fechamento de fábricas, a reestruturação industrial, o forte aumento do desemprego e forte refreamento dos investimentos privados. O governo brasileiro conteve os reajustes das bolsas de estudo e das mensalidades em função da perda do poder aquisitivo dos salários. Foram então desenvolvidos, pelas instituições, pela União, pelos estados e respectivos Conselhos de Educação, políticas e ações voltadas à sobrevivência das instituições, à garantia de seus lucros, incluindo-se incentivos fiscais e a participação 
do capital financeiro por meio do Programa de Crédito Educativo. (Cunha, 2012, p. 332-344).

Ao tratar dos custos da escola pública e da escola privada, o presidente da SBPC, no transcorrer da discussão no âmbito da Subcomissão, refutou a tese de que a escola pública seria mais cara que a privada. Ele apontava a necessidade de considerar se o setor público seria instado a realizar despesas que não tinham relação direta com o ensino, isto é, contabilizadas de forma indevida na área da Educação.

A Federação de Sindicatos de Trabalhadores Técnico-Administrativos em Instituições de Ensino Superior Públicas do Brasil (Fasubra) também se manifestou em defesa das propostas do Fórum Nacional em Defesa da Escola Pública na Constituinte a partir da realização da crítica da sociedade (28 abr.1987). Ao indicar a necessidade de uma ampla mobilização da sociedade brasileira para fazer frente às pretensões hegemônicas das frações das classes dominantes que teriam passado de uma condução repressiva para persuasiva, no Brasil, o documento da Fasubra entregue à Subcomissão apontava o esforço de tais setores no sentido de buscar legitimidade para impor dominação de seus interesses, bem como a necessidade de sustentação da luta por saúde, educação e trabalho com igualdade de acesso a toda população.

A Fasubra destacou, então, que a gratuidade da educação, em todos os níveis, se constituiria em condição para superação da divisão entre privilegiados e não privilegiados. Realizando em seu documento uma sumária avaliação das constituições brasileiras, salientava questões acerca do saber na sociedade capitalista:

Um elemento fundamental para a democratização da educação é a motivação escolar, que pode se apoiar na busca de um emprego à altura do curso, ou no desejo de simplesmente aprender. Mas, uma sociedade fundamentada no jogo capitalista da concorrência e do emprego como forma de afirmação no universo, poderá fazer predominar a motivação do saber puro, quando este não tem lugar no seu universo de valores? Não seria mais válida a busca de uma nova ordem que eliminasse o "capitalismo do saber" pela eliminação do capitalismo social e econômico? (Ibidem, p.151). 
A entidade realizou uma associação entre saber puro e superação da ordem capitalista como contraponto do saber enquanto instrumento de sustentação dessa mesma ordem. Presa em uma verdadeira armadilha, ao realizar sua análise apoiada numa contraposição dicotômica, a Fasubra apresentou uma pergunta para a qual o mero contraponto discursivo não oferecera resposta. O conhecimento como produção humana deslocado de sua temporalidade perde relação com o movimento da história.

A partir de tais considerações, apresentou um conjunto de proposições complementares àquelas do Fórum, que traduziram a orientação de verbas públicas para a escola pública: fim dos subsídios para as escolas particulares, tal como a proposta apresentada pela ANDES; fim do crédito educativo e das bolsas de estudo; estatização das instituições de ensino de primeiro, segundo e terceiro graus sem indenização ou absorção das dívidas de seus proprietários, uma vez que por ocasião da estatização as verbas públicas deveriam estar sob controle da comunidade escolar; regulamentação das escolas particulares até que fossem estatizadas; edição de livros didáticos pelo poder público submetida ao controle social e democrático da comunidade, com garantia de representatividade dos diferentes pontos de vista; criação de um imposto educacional aplicado às multinacionais, de $5 \%$ sobre o lucro total da empresa; e aplicação de pelo menos $2 \%$ do PIB em pesquisa científica e tecnológica. (Ibidem, p. 46-54)

O programa apresentado defendia a expropriação das instituições privadas pelo Estado, com controle social, visando à ampliação da oferta de vagas nas universidades públicas, que deveriam ser orientadas pelo princípio da indissociabilidade entre ensino, pesquisa e extensão e pela autonomia. Deveriam ser geridas democraticamente, com eleições diretas em todos os níveis, para todos os cargos de dirigentes das universidades, e gestão paritária nos órgãos colegiados. Deveria garantir a criação de cursos noturnos em todas as áreas e a convocação de Congressos Universitários e Estatuintes nas Instituições de Ensino Superior. Neste ponto, o programa da Fasubra se diferenciava da proposta da ANDES.

No que se refere à manifestação da Associação Nacional de Pós-graduação e Pesquisa em Educação (ANPED), realizada por seu presidente Osmar Fávero (28 abr. 1987), ela teve início com a apresentação da entidade que, envolvendo 33 programas de pós-graduação, alguns centros de pesquisa e 600 sócios, entre 
professores, estudantes e pesquisadores, foi uma das primeiras instituições a lançar o debate público sobre a Educação na Constituinte, além de elaborar o documentobase da IV Conferência de Educação, quando 6.000 educadores discutiram a Carta de Goiânia. (Ibidem, 132-3)

Ao tratar da necessidade de compromisso do Estado brasileiro com a educação pública e das condições de evasão e repetência no país, salientou que o sistema de ensino estava montado sobre o privilégio do Centro-Sul, e que as profundas discriminações que marcariam o sistema de ensino seriam de várias ordens: de sexo, de raça, de idade, de confissão religiosa, de filiação política e de classe social, além de regionais. As zonas mais pobres dentro dos estados e as regiões mais pobres do País teriam, então, os piores níveis de escolarização.

É daí a grande fonte do analfabetismo. O analfabetismo é o próprio
fracasso da escola elementar. É bom marcar estas coisas como
coisas bastante concretas. Associado a isso, quando se pedem verbas públicas para as redes de escolas públicas, passa em nossa consciência que, efetivamente, o compromisso fundamental do Estado, em particular do Ministério da Educação, não tem sido com o ensino das camadas populares.

O Ministério da Educação é, há vários anos, e hoje, particularmente, o próprio paladino da defesa do ensino privado.

Queremos marcar muito bem que esses dois princípios que pedimos sejam escritos na Constituição: da obrigação do Estado de atender ao direito de todos os cidadãos, passa, obrigatoriamente, por uma revisão fundamental na forma que está distribuída a educação, na forma como são organizados os sistemas de ensino, o que vai mexer com coisas que não estão apenas na esfera da educação. (ANC, 1988b, p. 132)

A manifestação destacaria ainda a necessidade de que a alfabetização e a educação de adultos estivessem inscritas na Constituição como direito. Observe-se que nas constituições anteriores este direito não foi assegurado e que incluí-lo significaria começar a assegurar a inclusão educacional de mais de 20 milhões de jovens e adultos. Reafirmando a necessidade de vinculação de recursos para a Educação, o presidente da ANPED foi além da Carta de Goiânia, indicando que, em termos históricos, quando na Constituição os percentuais mínimos foram desatrelados houve diminuição da oferta de vagas nas escolas públicas. Cito: 
Toda a substituição da defesa intransigente do ensino público através da vinculação de verbas substitui-la pela figura que progressivamente foi definida, que começa nos anos 45, mas tem plena expressão na Emenda Constitucional de 1969, ela é vexatória a todos nós, quando definidos de um lado o ensino como obrigatório, como fundamental da cidadania e obrigamos as camadas populares a pedir, de chapéu na mão, o favoritismo da bolsa de estudo que, na verdade, todos nós sabemos, favorece muito mais o sistema de escolas privadas. (Ibidem, p.133)

A crítica que aqui tomava forma dizia respeito às políticas que fizeram crer a seus beneficiários e à sociedade que direitos eram favores. Tal conversão reforçou, no imaginário social, a identificação de sujeitos caracterizados pela condição de privação, por um não ser ou vir a ser, representação que reforça e, em certo sentido, naturaliza a condição de desigualdade e exclusão social, fundamento da construção da noção de pobreza. Vera Telles considerou que pobreza e cidadania são categorias antinômicas, observando que:

Ao invés de pobre atado pelo destino ao mundo das privações, o cidadão que reivindica e luta por seus direitos: duas figurações opostas e excludentes da questão social. A indiferenciação do pobre remete a uma esfera homogênea das necessidades na qual 0 indivíduo desaparece como identidade, vontade e ação, pois é plenamente dominado pelas circunstâncias que o determinam na sua impotência. A figura do pobre se filia a uma sociedade autoritária que obsta a constituição de uma esfera pública na qual grupos e classes possam fazer valer seus interesse e razões. (Telles, 2013, p.51-2).

Já a presidente do Centro de Educação e Sociedade (CEES) ${ }^{50}$, Elizabeth Camargo (28 abr. 1987), depois de defender a Carta de Goiânia e o Documento do Fórum, reafirmou a necessidade de democratização da sociedade e do Estado como condição da democratização da educação:

E esse projeto temos que levar à frente, temos que criar a escola de qualidade neste País e, hoje, para mim, a única instituição, o único nível da sociedade que é capaz de fazê-lo, é o Estado e, para isso, temos que exigir a sua democratização.

Não somos o Estado porque as classes dominantes do Brasil sempre foram... Pregamos o chamado controle democrático sobre o Estado é isso que temos a fazer, é isso que os constituintes sérios devem fazer no seu dia a dia, exercer o controle democrático [...]. (ANC, 1988b, p.134)

${ }^{50}$ O CEDES foi fundado em 1979. 
A defesa da democratização do Estado tornou-se, para as entidades signatárias da Carta de Goiânia e integrantes do Fórum, um duplo desafio: proposta e prática fundacional. Assim foi percebida tal participação pelo CEES:

Outra coisa que eu queria colocar é que defendemos que as verbas públicas sejam exclusivamente para as escolas públicas, porque a escola privada, seja ela uma escola que faz um trabalho sério ou não, é uma instituição privada. Dizer que a escola é pública, mas não é estatal é falso. [...] Isto está mal empregado [...].

As nossas propostas, as propostas que as entidades apresentaram de um consenso, poderiam ser utilizadas pelo Governo, mas muitas foram perdidas, o caminhar está difícil em todos os níveis, por isso temos que assumir, na Constituinte, ao nível do Poder Legislativo, uma posição clara e não aceitar isso, como foi apresentado aqui: aprovaram um item de verbas exclusivamente para as universidades públicas e abaixo colocam - excepcionalmente. O que já foi um avanço acredito, ter-se chegado a isso.

$\mathrm{Na}$ realidade, as universidades públicas estão fechando porque essas verbas não vão apenas para projetos, não vão para instalações, vão para outras coisas, e entender financiamento no Brasil é coisa muito complicada.

Então o CEES fecha com todos os itens colocados aqui: escolaridade obrigatória, a questão da universidade, agora o eixo central é conseguirmos avançar por mobilização, fazer um trabalho de convencimento no sentido de não entrar nessa discussão marota de que a escola particular também é pública, não é! Temos que definir o que é público neste País. (Ibidem)

A fala da presidente da entidade identificou o público e o privado e qual o papel do Estado, localizando o espaço público e os meios de ação, ou seja, a luta social para ganhar adesões, convencer e estabelecer a negociação. A narrativa estabeleceu as entidades do Fórum como sujeito da pretendida democratização do Estado e a Constituinte como um dos espaços nessa direção.

\section{2 - A questão do financiamento: critérios e interesses das instituições}

A questão da democratização do Estado seria retomada pelo professor Jaques Veloso, da ANPED, ao tratar das dificuldades de obtenção de informações sobre o financiamento da educação no País. 
[...] Qualquer um que se detenha para estudar esse assunto verá que se trata, acima de tudo, de um garimpo de informações junto aos órgãos públicos, informações estas que deveriam estar à disposição de toda a sociedade brasileira.

Começo meu breve relato contando uma história que seria engraçada se não fosse trágica, do ponto de vista político.

Nos meus últimos garimpos, contei com a colaboração da jornalista Maenir Martins, que aqui está hoje, e esta jornalista, indo ao MEC colher informações adicionais, veio a descobrir que um dos secretários daquele Ministério, ao qual competiria gerir uma parte dos recursos da educação, desconhecia a outra parte dos recursos do Ministério; desconhecia que the tocava apenas menos da metade dos recursos que são arrecadados pelo Ministério da Educação do País [...]

O próprio Ministério reconheceu, em estudos recentes, que nessa compra de vagas, prevalecia, muitas vezes, o trabalho de intermediários entre as empresas e as escolas, intermediários esses que chegavam a receber $40 \%$ de comissão sobre os recursos que arrecadavam das empresas para aplicação nas escolas.

Ao longo do tempo esse mecanismo se aperfeiçoou de duas maneiras. Em primeiro lugar, o MEC passou a ter algum controle sobre a destinação desses recursos, em segundo, com a política deliberada do Estado, revelando seu descompromisso cada vez mais patente, com isso cresceu, assustadoramente, o volume de recursos que, em vez de se destinarem às escolas oficiais, destinavam-se às escolas privadas. Isso ocorreu através de um mecanismo chamado Sistema de Manutenção do Ensino, um eufemismo aos quais seus inventores esqueceram-se de acrescentar [...].(Ibidem, p. 135)

A manifestação de Jaques Veloso, na Subcomissão, ao indicar a importância de tornar públicos os destinos dos recursos públicos, retoma o problema da soberania interna - vale dizer, da legitimidade do próprio Estado - e busca desconstituir as políticas que patrocinam a utilização do que é público em benefício dos interesses privados. Ilustrando as questões inicialmente apresentadas, 0 pesquisador apontou que na Nova República se verificou a continuidade de queda da arrecadação dessa contribuição social. A arrecadação feita pelo IAPAS corresponderia a $42 \%$ do total da receita.

Para onde vai o resto do salário-educação? O que é esse resto do salário-educação?

Num passado recente, esse resto correspondia a empresas próprias, empresas que mantêm isso para os seus empregados, indenizações dos empregadores, a empregados que fazem Ensino Supletivo ou realizam estudos regulares em 
escolas de $1^{\circ}$ grau e bolsas, aquisição de vagas para filhos de trabalhadores nas escolas particulares e, também, bolsas para os chamados alunos da comunidade, alunos quaisquer que as empresas haviam por bem escolher, ou melhor, que as escolas escolhiam e procuravam recursos das empresas para que cobrissem seus estudos. Mais recentemente, com a mudança da legislação, diminuiu o número de alunos financiados diretamente pelas empresas, e cresceu o volume de recursos que sobravam no salário-educação, recursos que eram destinados pelas empresas a bolsas, ou seja, em resumo, as empresas, hoje, optam, preferem, de acordo com a legislação, destinar um volume gigantesco de recursos a bolsas de estudo, ou seja, esses $57 \%$ restantes, um resto maior do que a metade do salário-educação é destinada a bolsas de estudo. Está aí, então, como, em breves palavras, se compõe a origem e a destinação dos recursos do salário-educação.

Hoje, o total dos recursos do salário-educação é ponderável, pois em 1986 foi da ordem de 12 bilhões de cruzados, ou seja, $35 \%$ da despesa realizada pelo Ministério da Educação no ano passado.

Destes 12 bilhões de cruzados, mais da metade financia bolsas de estudo, em vez de financiar o ensino público. Bolsas concedidas ao ensino privado. (Ibidem, p. 135-6)

As considerações de Jaques Veloso foram impactantes porque desvelou as proporções do emprego dos recursos públicos para fins privados e, durante um período, a partir de critérios e interesses próprios das instituições. Além do salárioeducação, outras bolsas seriam concedidas às escolas privadas pelos governos estaduais e municipais e por outros órgãos federais, como a Fundação de Assistência ao Estudante e outros.

O quadro, apresentado por uma entidade de pesquisadores na área da educação, bem como as estratégias para ter acesso a elas, demonstrava o quanto o país teria que caminhar para que a produção e a socialização de informações integrassem o espaço público das discussões, dos conflitos e decisões entre as classes e grupos sociais. A forma de emprego e gestão dos recursos do salárioeducação tornava evidente a prática de um Estado que manteve a indistinção entre o público e o privado na vida em sociedade e que, por todos os meios, buscou naturalizá-la.

Os dados apresentados demonstravam que a mercantilização da educação, levada a efeito pelos militares, não teria sido transformada em sua substância. A Educação, concebida e figurada socialmente como mercadoria, era deslocada do mundo dos direitos para o dos privilégios e, por decorrência, deixava de pavimentar 
direitos políticos e civis. A polarização simplificadora entre carências e privilégios é o solo onde cresce a intencionalidade que impõe obstáculos ao direito à representação, à livre organização, à participação nas instituições da sociedade.

A transformação da educação em mercadoria comprometia também a criação e a produção da cultura, sua difusão e ressignificação como patrimônio social. A escola e a universidade pública, por natureza, são as instituições mais capazes de fomentar a investigação, a compreensão crítica das realidades históricas e da própria ciência, da tecnologia, da filosofia e das artes, condições para o exercício da liberdade e para compreensão dos assuntos humanos, tal qual concebeu Arendt (1993).

Com efeito, estavam em questão as políticas de um Estado cujas instituições recriavam históricas práticas autoritárias de clientela e dependência, transformando, como afirmou Marilena Chauí (1995), as diferenças e assimetrias em desigualdades que reforçariam a relação mando-obediência. Representando os pobres como maioria de necessitados, carentes e desamparados sociais, pretendiam continuar a torná-los ineptos a interferir nas dinâmicas de poder, deles subtraindo o direito de controlar e interferir nos rumos da coisa pública.

O outro jamais é reconhecido como sujeito nem como sujeito de direitos, jamais é reconhecido como subjetividade nem como alteridade. As relações entre os que se julgam iguais são de cumplicidade: e, entre os que são vistos como desiguais, 0 relacionamento toma a forma do favor, do clientelismo, da tutela ou cooptação, e, quando a desigualdade é muito marcada, assume a forma de opressão. Em suma: micro poderes capitalizam 0 autoritarismo em toda a sociedade: na família, na escola, nas relações amorosas, no trabalho, na mass mídia, no comportamento social nas ruas, no tratamento dado aos cidadãos pela burocracia estatal, no desprezo do mercado pelos direitos do consumidor, na naturalidade da violência policial, etc. (Chauí, 1993, p. 75)

Os pobres, tornados incapazes pelas políticas e suas representações, são deslegitimados para representar-se e experimentar o processo democrático e o exercício da liberdade. Assim, a apresentação de informações e interpretações da realidade social brasileira instalava a possibilidade e o espaço não apenas de reivindicações, mas de afirmação de sujeitos e direitos.

O professor Jaques Veloso retomou, no contexto do debate da Subcomissão, o problema da garantia da vinculação, da ampliação do percentual de vinculação e, 
ainda, de que os recursos fossem investidos na manutenção e desenvolvimento do ensino em todos os níveis de governo. Sua fala, ao entrelaçar responsabilidades políticas da Assembleia Nacional Constituinte e do Estado como caminho possível para concretização de diversas soluções, torna mais complexa a abordagem das questões relativas ao financiamento da educação e repõe, por outro lado, a ideia de fortalecimento da soberania interna como fonte da legitimidade do Estado para fazer valer os direitos sociais.

Oswaldo Della Giustina, representante do Grupo de Trabalho Educação e Constituinte do Ministério da Educação, (23 abr. 1987), tratou, a um só tempo, de problemas centrais da educação no País e das medidas necessárias para assegurar que os fundos públicos se estendessem ao Ensino Fundamental e a educação básica. O dirigente do MEC identificou as questões da obrigação, do dever de educar e do direito à Educação como aquelas em torno das quais deveriam se definir tanto a extensão da ação pública e privada e o alcance da gratuidade, quanto a origem dos recursos públicos, o montante necessário e como distribuí-lo. Além disso, foram apontadas também necessidades em relação ao acesso à tecnologia nas unidades de ensino e a questão do ensino dos chamados "excepcionais". Vale ressaltar que a referência ao atendimento dos excepcionais envolvia o debate sobre a transferência de recursos federais para a Associação de Pais e Amigos de Excepcionais (APAE), bem como, a questão da oferta de tecnologia e formação de profissionais nessa área envolvia também destinação de recursos.

Na mesma reunião de 23 de abril de 1987, o presidente do Conselho Federal de Educação, Fernando Fonseca, expressou preocupação tanto com o desafio de tornar a educação matéria constitucional, como com as políticas de governo marcadas por contradições entre a teoria e a prática.

Um dos desafios apontados pelo presidente do Conselho Nacional de Educação foi o relativo à fisionomia da Federação, considerada por ele uma ficção jurídica, uma vez que sem recursos os Estados não poderiam ter autonomia e não deveriam se constituir "em sócios de uma massa falida". Identificou três critérios para possíveis prescrições constitucionais:

[...] primeiro, a Constituição pode omitir-se, situando a educação no campo dos poderes residuais; segundo, pode atribuir, expressa e exclusivamente, a determinada categoria de Governo, a competência 
em matéria educacional; terceira, e, finalmente, optar pela competência concorrente em que a União e os Estados-membros recebam atribuições específicas e conjugadas em matéria de educação. É uma opção que prioritariamente deve ser feita, antes de tratar da matéria de educação propriamente dada à definição de direitos. (ANC, 1988 1, p.78)

Analisando exemplos internacionais, situa o Brasil que, desde 1891, tendo como princípio a prática e a competência concorrente, tornou a educação matéria constitucional. Ao reconhecer a tradição do direito constitucional brasileiro, considera que a educação deverá ser um tema obrigatório, ao mesmo tempo em que defendeu que fosse enxuta, seca e firme, para que não precisasse sofrer plásticas. A metáfora, que se contrapôs à constituinte salgada e molhada defendida pelo constituinte Florestan Fernandes, expressava a concepção de que antes das definições sobre a educação seria preciso defender o desenho federativo do país.

Fernando Fonseca (Ibidem, p. 79) apresentou, como objetivo central da Constituinte, a estruturação de um "Estado moderno, democrático, progressista, justo e tolerante com as ambiguidades", defendendo que a Constituição fosse uma carta de compromisso entre as várias tendências dos grupos sociais que compunham a chamada sociedade "pluralista brasileira", ambicionando perenidade, mas sem conteúdo de perpetuidade. O processo, sem maniqueísmo e radicalismos, deveria abrir espaço para o diálogo e para o consenso, apaziguando a contenda.

Além de pretender reduzir o campo das definições, deixando-as para a legislação infraconstitucional, ele indicou o que considerava fundamental: "definir o conteúdo do direito à educação e do dever do Estado".

Este delineamento foi acompanhado de dois alertas: o primeiro, o de que a Nação não teria assumido o desafio da educação nacional e o segundo, o de que a seriedade do tema não permitiria que o assunto fosse resolvido apenas por educadores.

Foi neste ponto que dois campos de representação fundamentaram o discurso sobre o direito e o dever de educar. $O$ primeiro, o de que seria recomendado um consenso, cujos pontos não foram explicitados, voltado para

\footnotetext{
${ }^{51}$ Competência residual é o poder de instituir outros tributos não previstos na Constituição Federal, em seus artigos 153, 154 e 155. No Brasil, somente a União detém a competência residual, nos termos do art. 154. (RAMOS, 2002)
} 
apaziguar uma contenda de conteúdo não declarado e entre sujeitos não identificáveis. Só foi feita referência aos educadores. A seriedade da questão educacional, ao não poder ser tratada apenas por estes profissionais, não sendo, portanto, particularizável, deles subtrai poder e competência conferidos a um espectro mais amplo de sujeitos nacionais. O segundo campo refere-se à Constituição detalhada, isto é, que se tornasse preciso o papel do Estado em relação ao dever de educar, ganhando o estatuto de perpetuidade, condição indesejável para uma Lei que, devendo promover o consenso, não poderia, ou não deveria abrigar e antecipar conflitos. Pode-se inferir que a Constituição e o consenso implicariam um campo de indefinições ou ambiguidades desejáveis, para que a Lei, em um futuro incerto, se encarregasse de definir, em um espaço público mais opaco, medidas apresentadas como realistas, condizentes com uma nação que até então não teria assumido o desafio da Educação.

É à luz da universalização do interesse ou desinteresse nacional pela Educação que o principal sujeito não identificado no discurso era legitimado: os setores privatistas que, com o Estado, deveriam assumir as responsabilidades pela oferta educacional no país, contando para isso com o recurso público.

\section{3 - Entre o público e o privado: a municipalização}

Como outra dimensão da relação entre o público e o privado, o debate acerca da municipalização da Educação foi retomado na Subcomissão. O representante do Ministério da Educação manifestou a preocupação do grupo de trabalho em relação ao tema:

[...] Mas, de modo geral, pela leitura dos documentos, há primeiro uma questão de preocupação com a descentralização que envolve não só a transferência de recurso, mas a natureza do recurso. O recurso é municipal; o recurso é estadual, é mais do que federal? Enquanto permanecer essa ideia de que a União é a dona e transfere o recurso para lá, ela sempre ficará com aquilo que é o poder fundamentalmente, e a descentralização se torna uma ilusão [...]

Em relação aos recursos do Ministério da Educação: primeiro os sistemas de $1^{\circ}$ e $2^{\circ}$ graus são estaduais. Dos recursos do 
Ministério da Educação, em torno de $60 \%$ do orçamento do Ministério da Educação, são transferidos para as universidades, para o Ensino Superior. Aliás, em torno de 60\%, creio que $90 \%$, para a manutenção do ensino federal, seguramente menos de $10 \%$ para a manutenção de ensino de outros graus [...]. Resta pouco de transferências do Ministério da Educação, isto é, da União, para os estados e municípios, resta muito pouco. Portanto, resta muito pouco,

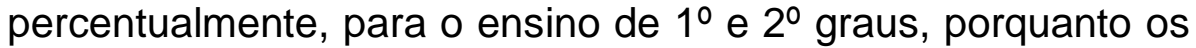
menos de $20 \%$ que restam são também, em grande parte, gastos na própria manutenção dos serviços da educação.

Chamo a atenção da importância que têm os programas sociais do Ministério da Educação, que não seriam educação, mas, em face das condições de miserabilidade do País, é a questão da merenda escolar que soma também significativos recursos, em torno de $5 \%$ em material didático - é a questão do livro didático. Se somarmos essas parcelas, praticamente esgotaremos o Orçamento do Ministério da Educação. (ANC, 1988 b, p.80)

A perspectiva de municipalização foi identificada como a da descentralização de recursos, fazendo crer que a questão das fontes de financiamento, assim como de sua distribuição, se constituiria na questão fundamental para que os municípios ampliassem suas responsabilidades na oferta educacional.

No que se refere ao grupo de trabalho do MEC, privilegiou a questão da repartição dos recursos federais. Apesar das injustiças tributárias indicadas, não havia referências às condições de geração de recursos em nível local, isto é, aos padrões de desenvolvimento econômico e social dos municípios e às desigualdades regionais. Esta tradição não estava sendo inaugurada no Brasil, pois, como demonstrou Melchior (2011), a supressão da vinculação de recursos na Constituição de 1967, e seu restabelecimento na Emenda Constitucional de 1969, apenas para os municípios ${ }^{52}$, fez com que os estados e os municípios, em particular os mais pobres, aumentassem seus esforços para assegurar educação pública, o que fez com que as responsabilidades fossem cristalizadas.

Outra presença importante foi a do Conselho Nacional de Secretários de Educação, representado por Gilda Poli Loures (23 abr. 1987), e que também identificou municipalização e descentralização, indicando a necessidade de que se

\footnotetext{
52 Emenda Constitucional de 1969. Artigo 15, parágrafo 3ㅇ: A intervenção nos municípios será regulada na Constituição do Estado, somente podendo ocorrer quando: não tiver sido aplicado, no ensino primário, em cada ano, de vinte por cento, pelo menos, da receita tributária municipal.
} 
respeitasse o princípio federativo e da coparticipação do Estado como ente. Segundo suas palavras: "temos que garantir não apenas responsabilidades, mas principalmente, recursos" (ANC, 1988b, p. 81). Estes deveriam garantir a execução de uma política educacional e de salários dignos para os professores. A posição era de que o município só poderia assumir o ensino de $1^{\circ}$ grau se possuísse pessoal qualificado para fazê-lo, para que a qualidade de ensino fosse preservada.

Além da centralização dos recursos federais e da indicação de números iguais aos apresentados pelo presidente do Conselho Federal de Educação, Fernando Fonseca, a fala da presidente apontou como problema a duplicação de serviços e de representações nos estados, estrutura considerada desnecessária, citando como exemplo as Delegacias Estaduais do MEC (Demecs). Reforçava essa perspectiva a ponderação feita pelo presidente do Conselho Federal no curso do debate desenvolvido com relação à ampliação da vinculação. Considerando-a desnecessária, sustentava os percentuais previstos na Emenda Calmon e tecia considerações acerca da municipalização:

Entendo, no entanto, que no artigo constitucional em que se determina que a União aplique percentual $X$ na educação, seja assegurada a prioridade para o $1^{\circ} \mathrm{grau}$, porque estamos verificando, neste País, que, apesar de toda ufania de que estamos vencendo o analfabetismo, existem Estados e unidades da Federação ainda com $47 \%$ de analfabetos. Acho que a União deveria, além dos 13\% fixados pelo texto constitucional, ou se for ampliado, a juízo de $\mathrm{V}$. Excelências dar prioridade a esse percentual na aplicação de recursos para a alfabetização, e à integração do homem brasileiro que está marginalizado do processo de desenvolvimento nacional.

De outra parte, eu esposo totalmente a tese da Dra. Gilda Poli, quando fala em centralização. Acho que deve ficar a critério dos estados a municipalização do ensino de $1^{\circ}$ grau, dando prioridade a recursos, mas recursos no sentido amplo, não só recursos financeiros, mas recursos humanos e que o Estado avaliasse qual 0 município ou quais os municípios que têm condições de assumir o primeiro grau. E que, se esses municípios não tivessem recursos suficientes, teriam, supletivamente, auxílio do percentual que ao Estado é assegurado, e do percentual que à União é assegurado [...] (Ibidem, p. 83)

O presidente do Conselho, ex-senador da República durante o ano de 1966 pela Arena, apontava a necessidade de uma revisão tributária para que se soubesse quais recursos seriam destinados ao município e ao estado, ao mesmo tempo em que fez uma severa crítica "às voltas do dinheiro público" desde que sai do controle 
da União até seu destino final. É interessante salientar que a municipalização esteve presente como perspectiva na Lei 5.692/71, sendo que o artigo 58 definia:

A legislação estadual supletiva, observado o disposto no artigo 15 da Constituição Federal, estabelecerá as responsabilidades do próprio Estado e dos seus Municípios no desenvolvimento dos diferentes graus de ensino e disporá sobre medidas que visem a tornar mais eficiente a aplicação dos recursos públicos destinados à educação ${ }^{53}$.

Parágrafo único - As providências de que trata este artigo visarão à progressiva passagem para a responsabilidade municipal de encargo e serviços de educação, especialmente de $1^{\circ}$ grau que pela sua natureza possam ser realizados mais satisfatoriamente pelas administrações locais. (Brasil, 1971)

Esta orientação não se concretizou como política pública durante os governos militares, mas ganhou impulso durante o processo de abertura política quando associada à ideia de descentralização tributária, em benefício dos municípios. A identificação entre municipalização e descentralização foi sustentada com argumentos como o de que, estando as escolas de $1^{\circ}$ grau sob a responsabilidade do município, pela proximidade no território entre o poder e os cidadãos seriam facilitadas a participação política e o controle social sobre as políticas e gastos públicos.

${ }^{53} \mathrm{O}$ artigo 15 da Constituição de 1969 estabelecia que a autonomia municipal seria assegurada:

"I - pela eleição direta de Prefeito, Vice-Prefeito e vereadores realizada simultaneamente em todo o País, em data diferente das eleições gerais para senadores, deputados federais e deputados estaduais;

II - pela administração própria, no que respeite ao seu peculiar interesse, especialmente quanto:

a) à decretação e arrecadação dos tributos de sua competência e à aplicação de suas rendas, sem prejuízo da obrigatoriedade de prestar contas e publicar balancetes nos prazos fixados em lei; e

b) à organização dos serviços públicos locais.

§ 3ำ A intervenção nos municípios será regulada na Constituição do Estado, somente podendo ocorrer quando:

a) se verificar impontualidade no pagamento de empréstimo garantido pelo Estado;

b) deixar de ser paga, por dois anos consecutivos, dívida fundada;

c) não forem prestados contas devidas, na forma da lei;

d) o Tribunal de Justiça do Estado der provimento a representação formulada pelo Chefe do Ministério Público local para assegurar a observância dos princípios indicados não Constituição estadual, bem como para prover à execução de lei ou de ordem ou decisão judiciária, limitando-se o decreto do Governador a suspender o ato impugnado, se essa medida bastar ao restabelecimento da normalidade;

e) forem praticados, na administração municipal, atos subversivos ou de corrupção; e

f) tiver havido aplicado, no ensino primário, em cada ano, de vinte por cento, pelo menos, da receita tributária municipal." (Brasil, 1969) 
Esta identificação deriva de uma representação que mobilizava a ideia de comunidade, na qual a presença temporal e espacial aproximaria os sujeitos, e estes com o poder. Neste discurso, não havendo lugar para descontinuidades, nem assimetrias políticas, nem desigualdades sociais, as transações entre o poder privado e o poder público, as práticas de clientela, a cooptação, o fortalecimento das hierarquias sociais e das relações de mando, a negação das diversidades sociais, regionais, a imposição de ideias, a perseguição e a violência contra a organização social e política que marcaram a cultura e as práticas políticas nos vários lugares do País deixavam de ser identificadas, reconhecidas e, portanto, não era objeto de reflexão. ${ }^{54}$

A relação imaginária eliminava do horizonte a perspectiva da intencionalidade e da proposta política, desconhecendo ou desconsiderando que a participação política nos assuntos públicos requeria reconhecimento do espaço público, criação de canais e práticas institucionais, democratização de informações e processo de formação dos sujeitos, para que se criasse igualdade de condições para a discussão, para a formulação de propostas, para o controle social e para a decisão. Enfim, o fortalecimento da cidadania é obra que envolve a decisão, a participação dos sujeitos e a decisão política daqueles que exercem o poder.

O discurso e a política voltados à municipalização atendiam tanto os adeptos da doutrina neoliberal - que começavam a ter influência no Brasil, depois de ganhar força na Europa e nos Estados Unidos, professando a retirada ou redução da participação do Estado nas atividades econômicas e no financiamento das políticas públicas -, quanto os privatistas, pois, em nível local, estariam mais defendidos dos mecanismos de controle público mais estruturado no âmbito do Estado Nacional. No âmbito dos municípios, as escolas confessionais teriam melhores condições para pleitear bolsas de estudo, assim como para buscar assegurar a efetivação do ensino religioso.

A Conferência Nacional dos Bispos do Brasil (CNBB) também se manifestou no dia 05 de maio de 1987, na 19a reunião da Subcomissão de Educação, Cultura e Esportes. De pronto, apresentou seis pressupostos coerentes entre si: O primeiro

\footnotetext{
54 Duas obras clássicas tratam do tema poder local: Coronelismo, enxada e voto, de Vitor Nunes Leal (1976) e O Mandonismo local na vida política brasileira e outros ensaios, de Maria Isaura Pereira de Queiroz (1976).
} 
era que, devendo o Estado estar comprometido com o bem comum, tudo que tornasse a sociedade mais humana deveria contar com o empenho e incentivo das instituições oficiais. $O$ segundo se referia à democracia, tanto mais autêntica quanto sua capacidade de defender direitos individuais e de grupos que se associassem para a realização humana mais profunda de seus membros. $O$ terceiro dizia respeito ao fato de que a sociedade, tendo conferido ao Estado o papel de educador, mas não de senhor absoluto da Educação, deveria tê-lo como facilitador das instituições que possibilitassem a todos os cidadãos o pleno desenvolvimento de suas potencialidades, incluindo-se a dimensão religiosa. $O$ quarto pressuposto indicava que a verdadeira humanização, uma das finalidades da educação, exigia o desenvolvimento da liberdade das pessoas, da família e da comunidade. O quinto, por sua vez, afirmava que um ensino de qualidade envolvia a opção pelo processo participativo e pelo desenvolvimento dos valores da pessoa humana, da cultura, da história de comunidades e pela pluralidade: de forma de vida, de concepções de homem, de organização sócio-político-religioso-cultural. Por fim, o sexto pressuposto: o de que não basta ao Estado declarar e afirmar um direito, é preciso que forneça os meios necessários e eficazes que favoreçam o seu pleno exercício. O Estado deveria assumir o dever de levar em consideração as aspirações do povo e da sociedade na escolha do tipo de educação que deseja, sobretudo nas escolas. (ANC, 1988b, p. 278-9)

\section{4 - Educação: dever do Estado ou direito da família?}

Um ambíguo sentido de humanidade tornou-se o vetor de articulação de um conjunto de significados na narrativa. Esse sentido, como valor estabelecido que se instaure mobilizando a afetividade, fixa pressupostos a partir dos quais todas as ideias e propostas entram em movimento sem comportar análise e, em consequência, a consciência das antinomias. Assim, este vetor de orientação se apresentando como válido, legitimaria todas as práticas individuais e associativas estabelecidas em seu nome. Melhor dizendo: todos os grupos, ou pessoas, voltados à realização humana em seu sentido profundo, se reconhecidos, confeririam à democracia um caráter autêntico. 
Outro suposto é o de que a sociedade teria conferido ao Estado papel educador. Sem que as intencionalidades e evidências de tal afirmação em relação ao processo democrático fossem explicitadas, outras questões surgem no discurso. Ao atribuir papel educador ao Estado, a sociedade não pretenderia torná-lo absoluto, em vez disso vislumbrava compartilhá-lo com as instituições que se ocupariam de fazer desenvolver todas as potencialidades humanas, incluindo-se a religiosa. Caberia ao Estado, por seu papel educador, validar e legitimar todas as instituições e pessoas que pudessem impulsionar o desenvolvimento humano, para o qual concorreria a religião.

Ao retomar a humanização como finalidade da Educação e, por conseguinte do Estado educador, surgiria como decorrência a liberdade afeta diretamente às três esferas de existência social estabelecidas no âmbito do discurso: o indivíduo, a família e as comunidades.

As comunidades imaginadas, não definidas e não nomeadas, aparecem como - locus onde se realizaria a participação, o cultivo das qualidades das pessoas, como condição da humanização. O sujeito que fala não manifesta intencionalidades, tampouco incertezas. Não se apresenta ao debate quando da abordagem de assertivas de caráter normativo em relação ao Estado. Assim, o silêncio sobre os conflitos que envolvem a participação, a oferta sobre o ensino religioso e sobre os recursos públicos para as instituições educacionais ligadas à Igreja Católica são a outra face do discurso que iguala, na vida em sociedade, as dimensões socialpolítica, religiosa-cultural tornando-as, depois de igualadas, expressão de pluralidade. Erigindo-as como o critério maior de qualidade da educação, elas são associadas e relacionadas ao desenvolvimento das pessoas e das, não nomeadas e identificadas, comunidades. Assim fundamentado, o direito à educação, para ser concretizado pelo Estado, careceria da interpretação das aspirações do povo e da sociedade no que se refere ao direito de escolha do tipo de educação que se deseja.

O Estado figura, nestas observações, articulando diferentes perspectivas do liberalismo. De um lado, representar o bem, a verdade e uma vontade geral das quais as comunidades, as famílias e os indivíduos seriam portadores, seguindo as tradições do liberalismo clássico e, de outro, agir em nome de determinados segmentos sociais (mudando o paradigma liberal de que representar seria estar no lugar do povo, agindo por ele e representando uma razão universal) (Chauí, 1993, p. 
292-7) -, em particular, as instituições que coincidiram com o Estado em seu papel de educar. Este Estado seria explicado por um discurso circular que se orienta pelo atendimento de necessidades e não pela garantia de direitos.

Ao levar em consideração as aspirações do povo, caberia ao Estado se constituir em facilitador, por meio da educação, da experiência de transcendência humana, uma das motivações para fortalecer o espírito de participação e a autêntica cidadania. Neste caso, o papel da Educação ultrapassaria as dimensões científicas e técnicas do conhecimento. A manifestação da CNBB acrescentou:

A sociedade como comunidade histórica, se firma em valores que sustentam a sua unidade. A sociedade brasileira está, sem dúvida, marcada pelo substrato religioso. O Estado, então, não pode se omitir desta responsabilidade de garantir a unidade da Nação na busca de um autêntico desenvolvimento democrático e social. $O$ Estado, e consequentemente, a Escola, não tem a função específica de formar os crentes das diversas confissões religiosas, mas garantir o desenvolvimento da dimensão religiosa que marca historicamente a cultura de todas as regiões do País. (ANC, 1988b, p.291).

A sociedade é apresentada como uma comunidade histórica que, pela via da experiência comum, estabeleceria elos e nexos identitários. A apresentação de tal comunidade, também imaginada, faz desaparecer as diferenças internas à sociedade e adiciona a religião à experiência comum, como um dos elementos da identidade nacional. Ora, sendo a dimensão religiosa marca da experiência cultural e, portanto, histórica, não deveria deixar de sê-lo, razão pela qual o Estado deveria proporcionar as condições para sua continuidade por meio da Educação como questão consensual e, portanto, aceita por todos.

Nesse discurso fica explícito o que Marilena Chauí (1993, p. 33) define como sendo a racionalidade da representação. A racionalidade do discurso ideológico tende "para o anonimato ou para a neutralidade, a fim de testemunhar uma verdade que estaria inscrita nas próprias coisas", deslocando a racionalidade do mundo para sua representação. "Não há mais necessidade de que alguém o pense: ele está posto aí diante de nós, como racional em si e por si".

A CNBB, autora do discurso não se colocava no contexto social como sujeito de uma experiência, de uma percepção, de uma convicção em relação a outros sujeitos e a outras convicções, reconhecendo e validando a pluralidade de outros discursos, propostas e ações. Bem ao contrário, se pôs como exterior ao contexto, 
construindo elos que terminaram por fazer coincidir fundamentos do discurso com a realidade, anulando no plano discursivo a separação entre Estado e sociedade.

Movido por tal perspectiva, ao Estado caberiam três campos de ação. De um lado, funcionar como uma agência financiadora e reguladora da oferta educacional, a ser apreciada e avaliada pelas famílias, visando à tomada de decisão quanto à formação de seus filhos, sem deixar de manter uma rede de escolas públicas. De outro, garantir as fontes de financiamento para a escola pública e mecanismos de financiamento (bolsas de estudo, por exemplo) nas instituições privadas de ensino. Além disso, no caso das escolas públicas, caberia ao Estado assegurar, nas instituições, a oferta de ensino religioso entendido como direito fundamental do educando, da família e da sociedade.

Observe-se que tal papel atribuído ao Estado o distinguia do Estado totalitário, aquele definido pela avidez do controle de todas as dimensões da vida em sociedade. O arcebispo de Aracaju, Luciano Cabral Duarte, já tinha apresentado os fundamentos dessa visão sobre o Estado. Assim escreveu em artigo para o Jornal do Brasil em dezembro de 1986, antes da instalação da Constituinte:

[...] o dilema com o qual vai confrontar-se o Congresso Constituinte é este: queremos dar ao Brasil uma Escola do Estado ou Escola da Nação? O Estado, em nossa Pátria, proclamando-se leigo (sic) não está ligado a nenhuma religião. Mas, a educação brasileira é o estuário onde se encontram três grandes correntezas: a Família, a Religião e o Governo, para conviverem no respeito mútuo e em paz. Uma escola fechada à Religião e puramente secularizada seria uma Escola do Estado, mas nunca seria a Escola da Nação [...].

Todas as ditaduras de esquerda ou de direita começam por estabelecer o monopólio do ensino. Depois, o dos meios de comunicação. E por aí vai, até a imposição de uma nova lista bíblica política, no gênero dos "Pensamentos do Presidente Mao-Tsé-Tung". O Brasil espera que seus novos constituintes não empurrem a Educação pela vertente estatal e secularizante. Este declive é inexorável e nunca soube conviver com a liberdade. (Duarte apud Cunha, 2009, p. 435)

Este debate retomava muitos dos argumentos desenvolvidos durante a Constituinte de 1946. O relatório da Subcomissão que tratou do tema da educação apresentou como formulação, no art. 6: "A educação é dever e direito natural dos pais, competindo supletiva e subsidiariamente aos poderes públicos". (Brasil apud Oliveira, 2005, p. 175) O deputado Ataliba Nogueira do PSD-SP assim justificou, à época, a formulação da Subcomissão: 
Chamo a atenção para o espírito que está sendo inoculado em nosso meio educacional de uns 16 anos para cá. llustrados colegas participam da concepção de que a Educação pertence ao estado principalmente, de que o estado pode contrariar a vontade dos pais, quando este art. 6을 diz precisamente o contrário. $O$ Estado não pode substituir-se aos pais de família na educação dos filhos. A tendência veio exatamente dos Estados antidemocráticos, que procuram modelar a infância à sua feição, ao passo que os pais perturbam tal modelação [...]

Se desejo dar a meu filho tal educação, não pode o Estado de maneira nenhuma impor que ele seja educado de outra forma. $O$ mesmo deve acontecer com a instrução.

Os pais são obrigados a ensinar; o Estado pode coagi-los a assim proceder, pois é dever deles [...]. Se os pais não podem acudir ao dever, então cabe ao poder público substituí-los [...].

Não estamos sempre invocando aqui o exemplo dos Estados Unidos? Pois ali, não só subsidiária é a ação do Estado, este como em outros assuntos de relevo?

O art. $6^{\circ}$ segundo o substitutivo é o seguinte: "A educação é direito de todos e deve ser ministrada pela família e pelos poderes públicos".

São direitos concorrentes. Não se vê a legítima preeminência da família. Pelas leis do Estado poderemos chegar à compreensão absolutamente totalitária da aplicação do texto. Não aceito, porque não atribui à família a preeminência da educação. (Nogueira apud Oliveira, 2005, p. 176-177)

Malgrado a crítica, a concomitância de responsabilidades se manteve no texto constitucional de 1946, bem como a responsabilidade pública na oferta dos diferentes ramos do ensino, assegurada a liberdade de oferta à livre iniciativa. ${ }^{55} \mathrm{Se}$, em 1946, o dilema esteve entre o direito (e o poder) dos pais de educar seus filhos, tornando o pátrio poder a única via de direitos em discussão, e o papel do Estado em assegurar a oferta educacional, a manifestação da CNBB em 1987 passava a movimentar, além do direito dos pais sobre os filhos, os direitos do educando. ${ }^{56}$

\footnotetext{
${ }^{55}$ O artigo 166 da Constituição de 1946 estabeleceu: A educação é direito de todos e será dada no lar e na escola. Deve inspirar-se nos princípios da liberdade e nos ideais de solidariedade humana. (Brasil, 1946)

${ }^{56}$ O Código Civil de 1916, substituído pelo Novo Código Civil em 2002, determinava em seu artigo 233 que o marido era o chefe da sociedade conjugal. $O$ artigo 380 definia que durante o casamento 0 pátrio poder competiria aos pais exercendo-o o marido com a colaboração da mulher. $O$ parágrafo único do mesmo artigo estabelecia que, em caso de divergências dos progenitores quanto ao exercício do pátrio poder, prevaleceria a decisão do pai, ressalvado à mãe o direito de recorrer ao juiz para solução da divergência. $O$ inciso I do art. 384 determinava que competia aos pais, quanto à pessoa dos filhos menores, dirigir-lhes a criação e educação. (Brasil, 1916) O Código Civil de 2002 estabeleceu em seu art. 1.511 o casamento como comunhão plena de vida, com base na igualdade de direitos e deveres dos cônjuges. $\mathrm{O}$ art. 1.630 estabeleceu que os filhos estão sujeitos ao poder
} 
À luz de tantos direitos fundamentais do educando, da família, da sociedade e do respeito à memória histórica de nossa gente cristã e das exigências de uma sociedade democrática nos fins e nos meios, seja assegurado na nova Constituição o direito ao ensino religioso, não como concessão do Estado, mas como direito fundamental do educando, da família e da sociedade brasileira. (ANC, 1988b, p. 291).

Com efeito, no contexto do debate em curso na Constituinte sobre os deveres, em vez de poderes, da família quanto à garantia do direito à vida; à saúde; à alimentação; à educação; à proteção ao lazer; à profissionalização; à cultura; à dignidade; ao respeito; à liberdade e à convivência familiar e comunitária e proteção contra exploração, violência, crueldade e opressão, a CNBB pretendeu introduzir o ensino religioso como direito fundamental. Assim propôs: "Respeitadas a opção e a confissão dos pais ou alunos, o ensino religioso constituirá componente curricular na educação escolar de $1^{\circ}$ e $2^{\circ}$ graus das escolas estatais." (Ibidem, p. 292)

Entre a garantia de direitos às crianças e adolescentes e o direito dos pais, se constrói uma narrativa cuja ambiguidade permite atar, no mesmo discurso, tanto a proposta de ensino religioso nas escolas estatais quanto a liberdade de escolha pelas famílias, das escolas em que seus filhos poderão estudar. Entre as conclusões expressas na manifestação da CNBB:

Vale para a Educação e para o ensino nas escolas o critério fundamental de que compete à sociedade ser sujeito coletivo da transformação social, e neste sentido utilizar a mediação do Estado para que a vida democrática se aperfeiçoe e a justiça prevaleça nas relações sociais.

À sociedade cabe, portanto, orientar e controlar o Estado para que haja educação e ensino que atendam às necessidades e aspirações da sociedade.

Todos têm o direito inalienável não só à instrução, mas a uma educação escolar plena e de qualidade, gratuita e obrigatória, e na escola que melhor atender às necessidades dos alunos e às aspirações de seus pais. (Ibidem, p. 291-2)

Como se pode verificar, a transformação social surge como um objetivo que deve ter um sujeito coletivo - a sociedade. Sujeito cujas falas e propostas não se distinguem ou diferenciam, mas que tem no Estado o mediador de uma vida social

familiar, enquanto menores. $\mathrm{O}$ inciso I do art. 1.634 se manteve tal qual o art. 384 do Código Civil de 1916. (Brasil, 2002) 
democrática, voltada à justiça social. Todavia, o próprio Estado, por meio da democracia que venha a assegurar, deve ser orientado e controlado pela mesma sociedade indistinta, a qual, ainda que não se apresente a partir de seu movimento interno, tem necessidades e aspirações. Este Estado, como ente público, deveria garantir educação gratuita e de qualidade como direito, que no discurso assume a forma de interesse privado, posto que transmutado em necessidades dos alunos e aspirações particulares de seus pais. No que diz respeito ao direito dos pais - como sinônimo de poder dos pais - se sobrepunha ao direito dos filhos. Esta sobreposição era funcional no plano discursivo e político, pois deslocava o acesso à cultura para os domínios privados. Se reconhecido o acesso aos conhecimentos científicos, filosóficos e tecnológicos por meio da Educação, como direito universal de crianças, jovens e adultos, independentemente da posição econômica do sujeito e de qualquer outra característica, era a questão da igualdade e da superação das iniquidades que recolocaria o papel do Estado como ente capaz de assegurar o direito e a lei. As observações da CNBB permitem entrever o movimento de constituição do discurso ideológico na medida em que se tornava impessoal, estabelecendo a passagem do discurso de para o discurso sobre a sociedade e a política. (Chauí, 1993, p.19)

Apresentando propostas mais específicas, manifestou-se o presidente da Associação Brasileira de Escolas Superiores Católicas (ABESC), Waldemar Valle Martins, em 29 de abril, na 16 ${ }^{\text {a }}$ reunião da Subcomissão. Antes, anunciou sua participação no Conselho de Reitores das Universidades Brasileiras (CRUB), indicando seu campo de alianças e esclarecendo o compromisso das Universidades Católicas com a qualidade de ensino e as dificuldades financeiras dessas instituições, em face da "desproporção entre custos e receitas" (ANC, 1988b, p. 168). As propostas apresentadas foram as seguintes:

1ㅇ Somos favoráveis à liberdade de ensino, que é condição e decorrência do regime democrático;

$2^{\circ}$ entendemos que o interesse maior da família brasileira é o acesso à educação de qualidade;

3o reafirmamos a prioridade, a obrigatoriedade e a gratuidade do ensino de $1^{\circ}$ grau para todos, cabendo ao Estado oferecer as condições e meios necessários para isso; 
$4^{\circ}$ com relação ao $2^{\circ}$ e $3^{\circ}$ graus, afirmamos o dever do Estado em garantir 0 acesso a instituições desses níveis aos cidadãos capacitados, mas carentes de recursos;

$5^{0}$ com relação à destinação dos recursos públicos, entendemos que - Estado, além de manter as escolas de sua criação e responsabilidade, deverá também subvencionar as instituições que, pela sua atividade, contribuam relevantemente para a cultura, 0 ensino ou a pesquisa no País, na forma regulamentada por lei. (lbidem)

O presidente da ABESC esclareceria que as Universidades Comunitárias estavam sob a responsabilidade de uma associação ou fundação sem fins lucrativos, confessionais ou não. Reconhecidas como idôneas para prestação de serviços educacionais de interesse público, aplicariam seus recursos e resultados financeiros em suas finalidades universitárias. Outra informação destacada foi a de que vinte universidades comunitárias receberiam subvenções do poder público, e que tais verbas, destinas às instituições particulares, seriam inexpressivas, representando $0,58 \%$ dos recursos destinados ao Ensino superior.

Observe-se que, na narrativa, a análise sobre a execução orçamentária e a destinação de recursos desliza das referências às Universidades Comunitárias para as demais Universidades Particulares, construindo uma outra comunidade de interesses. Nessa perspectiva, o discurso seria uma das dimensões de enlace entre as diferentes instituições privadas na disputa pelos fundos públicos.

Retomando o debate sobre a Escola Comunitária, o presidente da Campanha Nacional de Escolas da Comunidade explicou que tal Escola seria diferente, isto é, não seria nem a favor nem contra a escola pública e a escola particular. Também afirmou que o governo destinava uma pequena parcela às escolas particulares e que os que faziam parte da Campanha Nacional de Escolas da Comunidade estavam muito interessados em saber quanto o Governo iria gastar em educação: "Que gaste muito, se tiver muito para gastar"! Declarando estar em quase todos os estados do País (ANC, 1988b, p.169) com cerca de mil escolas, a Campanha agradeceu a ajuda das comunidades e dos governos estaduais e municipais. (Ibidem, p.169)

Sem que fossem apresentados os sujeitos das comunidades e como as chamadas escolas comunitárias se organizavam no presente, foram destacadas apenas as ajudas governamentais em nível local e o número de instituições distribuídas pelo País, de sorte a tornar claro o prejuízo que significaria seu 
fechamento em face da ausência de número suficiente de escolas públicas. O presidente da entidade encerrou sua fala mobilizando e articulando um conjunto de imagens que visavam a legitimar a existência de tais instituições: "Este é o esforço de uma escola que nasceu com os estudantes de Recife, e no meio dos operários, com teatro que ali formamos para conseguir recursos para aquisição das primeiras carteiras de nossos primeiros alunos". (Ibidem) A existência das escolas comunitárias estaria legitimada por sua origem, por uma relação inespecífica entre os estudantes e os operários que, num esforço de ação conjunta, teriam conseguido os primeiros recursos para sustentá-las.

Em sintonia com as diretrizes da Conferência Nacional dos Bispos do Brasil, tendo como referência a opção preferencial pelos pobres e a busca da transformação social, a Associação de Educação Católica no Brasil (AEC) se apresentou na 16 reunião da Subcomissão, em de 29 de abril de 1987, como entidade que buscaria apoiar os educadores católicos de escolas públicas e particulares na reflexão sobre educação. Comprometendo-se com uma sociedade onde "todos gozem dos mesmos direitos e não seja tolerado nenhum tipo de discriminação" a associação dizia defender, simultaneamente, uma sociedade livre, pluralista e participativa, na qual o Estado fosse o instrumento a serviço da sociedade, subordinado e controlado por ela (Ibidem, p.182-3).

Tais princípios constituir-se-iam dos fundamentos da defesa de uma escola pública de qualidade para todos, mas também dos questionamentos sobre sua definição. Assim, concordando com o slogan que diz: "dinheiro público para escola pública", a entidade defendeu uma ampliação do significado do que seria a educação pública colocando-se contra a estatização e o monopólio. Entendendo o confronto entre a escola pública e particular como velho e defasado, remontando à Revolução Francesa, o padre Agostinho Castejon, presidente da entidade, rejeitou o que considerou "desvios da mercantilização da Educação em casos extremos" (Ibidem. p 182).

Eis aqui uma das inflexões mais significativas do discurso da Igreja Católica, quando o privado é convertido em coisa pública e a definição semântica se torna o prenúncio da indiferenciação necessária à aliança política entre a Igreja e os empresários da Educação. A antinomia presente na estrutura argumentativa seria 
justificada pelo "pluralismo na educação" concretizado na Nicarágua e em outros países.

[...] Esse sistema de escolas públicas não estatais e gratuitas, financiadas pelos poderes públicos, com recursos públicos, existia no Chile no tempo de Eduardo Frei, no tempo de Allende e existe no tempo de Pinochet. Existe o sistema na Argentina, na Espanha, na Bélgica, na Alemanha, na França, etc. Por que não pode existir uma coisa desta no Brasil. (Ibidem)

Desta maneira, tais escolas estariam legitimadas pela existência em conjunturas diversas, fosse sob a direção do Estado ditatorial ou democrático. Esta condição atemporal das circunstâncias históricas permitiria que a experiência transitasse para o Brasil tornando possível aos pais exercerem a liberdade de escolha para seus filhos. Ao abrandar a crítica à mercantilização e ao pretender a constituição de dois sistemas públicos de educação, um estatal outro não, o discurso sedimentava, em nome da liberdade e das carências sociais, uma forte aliança com os setores empresariais. Esta redefinição do público permitiu, como demonstrou Luiz Antônio Cunha, que a Confederação Nacional dos Bispos do Brasil (CNBB), a Associação de Educação Católica do Brasil (AEC) e a Associação Brasileira de Escolas Superiores Católicas (ABESC) formulassem uma proposta de emenda que combinava o apoio do Estado ao ensino privado e a manutenção da oferta de ensino religioso nas escolas, reunindo 750 mil assinaturas. (Cunha, 2012, p. 436).

O conteúdo da apresentação realizada por Roberto Dornas, presidente da Federação Nacional dos Estabelecimentos de Ensino, corroboraria com o conteúdo da aliança dos chamados setores privatistas ${ }^{57}$.

A nossa proposta quanto ao Capítulo da Educação já foi formalizada nesta subcomissão. Preferimos tratar de alguma coisa mais transcendental, porque o receio que se tem é que na Constituinte predomine o debate do facciosismo, do sectarismo, sem que se chegue àquilo que é o intuito da sociedade brasileira - uma democracia plural, em que o indivíduo seja respeitado na sua individualidade como ser humano [...].

Numa sociedade em que, lado a lado, possa viver o católico, possa viver o evangélico, possa viver aquele que se convence de seu

\footnotetext{
${ }^{57}$ Estamos aqui considerando a definição de Luiz Antônio Cunha, segundo a qual o privatismo consistiria na prática de pôr a administração pública a serviço de grupos particulares, sejam econômicos, religiosos ou político partidários.
} 
ateísmo, possa viver o marxista, possa viver o nazista, possa viver qualquer um.

Então o transcendental, em matéria de educação na Constituição é construir essa democracia plural de amanhã. (ANC, 1988b, p.180)

No plano discursivo, como uma das dimensões do embate que se estabeleceria com mais força no plano político, a aliança com a Igreja Católica se faria expressar por meio das referências ao campo dos valores, apresentados como expressão da liberdade humana.

Por enquanto, temos visto que se bate apenas pela instrução, e não pela Educação. Instruir é muito diferente de educar. Cada pai procura, e quer para seu filho, criá-lo e educá-lo nas suas convicções filosóficas, nas suas convicções religiosas, nos valores em que acredita. Todos procedemos desta forma. Se cada um tem uma crença, uma convicção, uma filosofia, é preciso que ele encontre uma escola que vá dar a seu filho a educação de sua preferência, conforme aquilo que ele acredita. (Ibidem)

A dimensão axiológica da formação dos educandos tornar-se-ia, de acordo com esta manifestação, uma prerrogativa de algumas escolas particulares, identificando-se o Estado com a instrução ao invés da formação. A ética como uma dimensão do processo de conhecimento é subtraída do campo de possibilidades da educação pública:

Não vejo nas escolas dos países totalitários formarem a democracia de amanhã. Não vi nos parlamentos dos países totalitários a pluralidade e as divergências que existem neste Parlamento.

E como se golpeia a democracia de amanhã é golpeando a Educação na sua base, é formando a criança pela vontade do Estado, do Estado que impõe. A preocupação da escola particular é que a sociedade futura do Brasil não seja um Chile, não seja um Paraguai, não seja uma Alemanha de Hitler, não seja uma Itália de Mussolini, não seja a Nicarágua, porque lá não vemos este Parlamento, lá não vemos esta diversidade.

Transcendente, se quer democracia, temos que ter uma escola essencialmente plural. (Ibidem).

Não estava em debate na Subcomissão qualquer proposta que impedisse as escolas privadas, confessionais ou não, de existir. Por tal razão, o discurso acerca do exercício da liberdade como uma representação anti-totalitária mostra-se, uma vez mais, instrumental, isto é, mobilizado para atender à finalidade específica de, em nome da liberdade, assegurar-se a continuidade de acesso aos fundos públicos no 
País. Esta perspectiva é desnudada verificando-se como são mobilizadas as experiências internacionais no âmbito do discurso. A Associação de Educação Católica procurava demonstrar a validade da concepção da escola pública não estatal, isto é, financiada com recursos públicos, na Nicarágua e também no Chile. Ter se mantido nos governos de Eduardo Frei, de Allende e de Pinochet conferiria uma universalidade legitimadora à experiência. Já a Federação Nacional dos Estabelecimentos de Ensino (FENEN), referindo-se aos mesmos países, os tomaria como o inverso da liberdade, e que as escolas não estatais financiadas com recurso público deveriam ajudar a promover e sustentar.

A compreensão desta relação instrumental com a democracia se completa se examinadas as propostas apresentadas no documento entregue à Subcomissão pela FENEN. No item V intitulado: "Direito da família, liberdade de ensino e garantia do direito de escolha", lê-se:

1 - O primeiro artigo e seus três parágrafos iniciais almejam estabelecer:

a) os princípios democráticos que devem orientar a educação;

b) o princípio de que a educação é direito da família, conforme suas opções, e dever do Estado, e não direito deste;

c) a liberdade de qualquer um de respeitadas as orientações legais, ministrar a educação e ensino, para atender às diversas opções das famílias;

d) garantia efetiva à família seja qual for a sua condição econômica, de escolher a escola de sua preferência;

e) a gratuidade de ensino, para o carente, em qualquer escola.

Hoje, quem tem meio, embora pagando imposto e tendo direito a ensino gratuito, pode escolher uma escola batista, metodista, católica, leiga, marxista ou nazista, conforme sua preferência; ao pobre não se permite o direito de crença, de religião, de filosofia, de ideal, de opção, porque só tem - querendo ou não - a escola pública. Confunde-se gratuidade de ensino com escola oficial, que não é gratuita, porque é paga regiamente pelo imposto de todos, dela usufruindo apenas alguns. (Ibidem, p. 213)

O texto permite entrever a luta retórica pela definição de liberdade, além da proposta de que o Estado se tornasse o ordenador de um mercado de ofertas educacionais no qual ela - a ideia - estivesse adstrita. Note-se que a liberdade aprisionada na discussão sobre as opções educacionais, silencia a necessidade de expressão e do seu exercício (da liberdade) nas próprias instituições educacionais, isto é, as manifestações se abstêm de tocar na questão da democracia como 
condição do exercício da liberdade nas instituições, nas redes de ensino e nos Conselhos de Educação.

A liberdade, de acordo com o pensamento liberal da FENEN, deveria ser assegurada também por meio da garantia do ensino religioso nas instituições públicas, já que nas instituições privadas a escolha seria feita na matrícula. Tal declaração atava os interesses da livre iniciativa e das escolas confessionais.

O texto propunha ainda a elevação das verbas para educação, imunidade tributária e fiscal, posto que a realização de tais atividades poupasse gastos ao Estado. Propunha-se assegurar que a contribuição social do salário-educação fosse realizada diretamente na comunidade onde estivesse situada a empresa, sem que fosse arrecadado pelos órgãos públicos e percorresse o fluxo do Estado. (Ibidem, p. 212-3)

Por fim, vale ressaltar que o texto produzia uma noção de pobreza, que poderia ser minimizada pela pluralidade do mercado educacional, conferindo aos pobres tantas oportunidades quantas oferecidas às classes médias e às elites. $O$ presidente do Conselho de Reitores das Universidades Brasileiras (CRUB), reitor Rodolfo Joaquim Pinto da Luz, ratificou essa posição. Assim se manifestou:

Nós temos defendido sempre que o ensino, a Educação é una. Não há como distinguir primeiro, segundo, ou terceiro grau, ou quarto grau. É indispensável para o desenvolvimento e para transformação deste País um investimento maciço na área educacional [...]

É necessário e substancial que não só se mantenha o atual percentual de vinculação, como também que esse percentual seja ampliado. Sabemos que uma das reivindicações históricas era no sentido de que $12 \%$ do orçamento nacional fossem destinados à Educação. E a emenda, como foi aprovada, o que já representou um grande avanço, destinou $13 \%$ dos impostos. Isso significa praticamente a metade, em termos de orçamento como um todo, tanto da União como dos Estados e Municípios.

Precisamos, então, não só garantir como também ampliar. Uma alternativa para essa transformação que precisamos fazer no país seria, após a Constituinte, não só regulamentarmos o sistema educacional que precisamos ter, mas também um amplo plano educacional que definisse quais as prioridades, quais os investimentos necessários.

A partir daí, poderíamos ter recursos crescentes destinados à área educacional e, após um período, uma avaliação feita pelo próprio Congresso Nacional e por toda a sociedade brasileira que ele representa, para conhecermos resultados desse plano. 
Poderíamos ter, então, progressivamente, uma vinculação orçamentária maior, sem causar prejuízos às demais áreas em que o Governo e a Nação precisam investir através do Estado.

Mas também devemos dizer que, se o ensino gratuito, em todos os níveis, deve ser assegurado pelo Poder Público, não podemos desconhecer também que há necessidade de aquelas instituições, que têm um eminente caráter público, e não mercantilista, como aqui já se abordou, venham a ter apoio do Poder Público, já que prioritariamente, diríamos até exclusivamente, as verbas do orçamento público devem ser destinadas para as escolas públicas. Excepcionalmente, deveremos destinar àquelas instituições, que têm promovido o desenvolvimento do ensino, da pesquisa e da extensão, esse apoio necessário, sob a pena de prejudicarmos 0 desenvolvimento também da Educação neste País. (Ibidem, p. 111)

A manifestação do CRUB trazia um componente novo ao debate, qual seja o de considerar o Plano Nacional de Educação como instrumento da definição de prioridades para destinação de recursos, uma espécie de modulador e regulador das metas da Educação. Assim, a avaliação dos resultados do Plano Nacional, pelo Congresso Nacional e pela sociedade, condicionaria uma progressiva ampliação da vinculação de recursos. Indicando a necessidade de tornar a Educação prioridade, de assegurar com urgência o $1^{\circ}$ grau no País e da necessidade de aumento dos fundos públicos, a manifestação do CRUB ia ao sentido de ampliar a vinculação de recursos para a área da Educação. $O$ representante do CRUB parecia indicar também como contrapartida a proposta de destinação de recursos públicos para as instituições privadas, consideradas e nomeadas como de interesse público.

Na realidade, o que este país precisa realmente é decidir pela prioridade à Educação. Os recursos são escassos, limitados e sempre o serão dadas as necessidades não só sociais como outras que o País tem.

A falta de recursos, hoje, é flagrante em todos os níveis do ensino, seja $1^{\circ}, 2^{\circ}$ e $3^{\circ}$ graus. Então, impõe-se uma resolução imediata. É esta, pois, a decisão que solicitamos aos Srs. Constituintes. Quanto vamos destinar em recursos? Não apenas os $13 \%$. Tendo defendido que, se fossem aplicados $25 \%$ do orçamento nacional - mas não é esta a posição da entidade, portanto, não vou defendê-la aqui poderíamos priorizar a Educação neste País. Depois faríamos uma reavaliação, para saber onde nos encontramos (Ibidem, p. 122)

No contexto do debate, após a manifestação do presidente do CRUB e de outros parlamentares, vale destacar outra vertente de abordagem apresentada pelo senador João Calmon (PMDB-ES), ligada à ideia da regulamentação dos artigos constitucionais. Senão, vejamos: 
Não adiantará nada ou quase nada a inclusão na nova Constituição de percentuais maiores para a área de educação. Porque a constituição é por definição um documento sintético e não analítico. A constituição, para ser cumprida, exige, como no caso da educação, uma lei complementar e uma lei ordinária. E temos, no caso concreto desta emenda que vinculou um percentual mínimo; a confirmação desta tese. A emenda foi aprovada e incluída na Constituição nos últimos dias de novembro de 1983. Entretanto, o todo poderoso Ministro do Planejamento à época, o hoje Constituinte Deputado Delfim Netto, decidiu não cumprir essa decisão do Congresso sob a alegação de que a emenda precisaria ser regulamentada para ser cumprida. Isso não passava de uma mentira, de um sofisma, porque o artigo da Constituição, nesse caso, é auto aplicável e independeria, para a sua aplicação, de qualquer regulamentação.

$\mathrm{Na}$ realidade, decorreram os anos de 84,85 e só em 86 , no ano passado, começou a aplicação dessa emenda. E não podemos, de forma nenhuma, desde logo, responsabilizar os que não cumpriram a emenda, porque a regulamentação desse inciso constitucional prevê que na hipótese do não cumprimento da emenda num determinado exercício, se fará um levantamento da diferença, e ela será transferida para exercício seguinte, portanto para o exercício de 1987, que ainda, obviamente, não chegou nem na sua metade.

De maneira que me parece fundamental essa esplêndida mobilização feita pela CPD, agora pela Andes, pela Fasubra, que são entidades combativas, aguerridas, sempre a serviço da educação. Que esta mobilização deva continuar para que se obtenha uma regulamentação que não frustre as aspirações de toda a sociedade brasileira, que considera a educação, sem dúvida nenhuma, da mais alta prioridade. (Ibidem, p. 126)

$\mathrm{Na}$ continuidade dos debates, se manifestou a UBES, reafirmando as propostas do Fórum e lançando como questão: "Qual é a parcela de jovens que pode pagar duas vezes pela educação em nosso País? Com certeza, é uma ínfima parcela que o faz por opção." (Idem, p. 131). Esta questão colocou o problema da natureza das políticas levadas a efeito pelo Estado brasileiro, do uso do dinheiro público e, ainda, o quanto elas produziram de exclusão da juventude em relação ao acesso à Educação.

Tomando a questão do crescimento do ensino privado como central, a presidente da UNE, Gisela Moulin Mendonça, na reunião da Subcomissão de 29 de abril de 1987, apontou que entre 1964 e 1982, o número de matrículas na rede particular cresceu $1.470 \%$, enquanto as matrículas na rede pública cresceram apenas em 590\%. As 25 universidades públicas criadas após 1964 o foram sob o regime jurídico único de fundações que definiam que no mínimo 1/3 das receitas deveriam ser provenientes de fontes privadas. 
A estas medidas de orientação privatizante se somou a diminuição de recursos públicos para as universidades públicas, redução de salários de professores e funcionários, afastando das universidades públicas seus melhores funcionários e comprometendo a qualidade da docência e da pesquisa, além de ter esvaziado as universidades. Paralelamente, a presidente da UNE apontava a ausência de investimentos na manutenção dos prédios e equipamentos, comprometendo o patrimônio público, dando como exemplo a redução de investimentos na Universidade Nacional de Brasília (UNB), que teria recebido apenas $20,7 \%$ das verbas necessárias para o seu funcionamento. Ao mesmo tempo, quatorze universidades privadas receberiam verbas do governo federal, por meio do Projeto Nova Universidade, o que seria desnecessário, posto que as instituições privadas tinham lucros expressivos, conforme teria apontado o Instituto de Pesquisas Econômicas da Universidade de São Paulo. Ao tomar como exemplo a Universidade Federal do Rio de Janeiro, em que metade dos 1.400 daqueles que ingressam pelo vestibular abandonariam a instituição, a UNE chamava a atenção dos deputados constituintes para a progressiva evasão na universidade.

A apresentação da situação do Ensino Superior vinha acompanhada da exigência de que os constituintes se comprometessem com a perspectiva de que o conhecimento se tornasse efetivamente um patrimônio da humanidade e não propriedade de poucos:

Ninguém mais do que a UNE e as entidades que formam hoje o Fórum de Educação Pública na Constituinte defendem a liberdade de ensino [...]. A todas as correntes religiosas, as correntes filosóficas, que quiserem ter uma escola, sendo sustentada pelas próprias correntes, isto devem ser garantidas. Não se podem fechar os olhos - já que é uma questão de vida a questão da educação - para esta situação que temos hoje no País.

A liberdade de ensino só vai ser efetivada, realmente, quando houver a opção de escolha, o que não existe hoje. Existe hoje uma escola pública que não assimila e não comporta o conjunto da população brasileira.

E esta é a verdadeira liberdade de ensino que esta Constituição quer garantir. (Ibidem, p.182)

A Confederação de Professores do Brasil (CPB) registrou alguns dados sobre a situação de atendimento educacional: $85 \%$ das crianças de dois a seis anos estariam fora do atendimento; oito milhões de crianças de 7 a 14 anos estariam fora 
da escola; 10 milhões de jovens que deveriam ser atendidos no $2^{\circ}$ grau estariam sem atendimento. Em face deste quadro, a CPB reafirmou as propostas apresentadas pelo Fórum, destacando que a União deveria aplicar nunca menos de $13 \%$, e que os Estados, o Distrito Federal e os Municípios 25\%, no mínimo, da receita tributária, exclusivamente na manutenção e desenvolvimento dos sistemas oficiais de ensino. Defendeu também que os recursos do salário-educação deveriam ser destinados exclusivamente ao ensino público oficial de 1ํgrau, sendo vedado seu emprego para qualquer outro fim.

A CPB defendeu ainda que a lei estabelecesse, em nível nacional, princípios básicos das carreiras do magistério público para os diferentes níveis de ensino, assegurando o provimento de cargos e funções mediante concurso público de títulos e provas, condições dignas de trabalho e aperfeiçoamento profissional, piso salarial mínimo, estabilidade no emprego (sob qualquer regime jurídico), aposentadoria com proventos integrais, aos vinte e cinco anos de serviço em funções do magistério, direito irrestrito à sindicalização, paridade de tratamento entre ativos e inativos e aplicação do estatuto do magistério municipal, em todos os municípios que dispusessem de rede própria de ensino. Por fim, o dirigente da CPB apontou a necessidade de que o texto constitucional previsse mecanismos legais para cobrança do Estado em caso de omissão. A pauta apresentada pela Confederação indicava a necessidade de que fossem criadas as condições de profissionalização dos educadores no país.

As propostas apresentadas pretendiam constituir-se em resposta a problemas tais como: $62 \%$ de professores não habilitados em nível de $1^{\circ}$ e $2^{\circ}$ graus; $95 \%$ dos professores municipais da Paraíba recebendo menos que um salário mínimo, o mesmo se repetindo com 93\% dos professores do Ceará, do Maranhão e do Piauí, 90\% dos professores municipais de Alagoas, $80 \%$ dos professores municipais do Pará e do Rio Grande do Norte, 65\% dos professores municipais da Bahia, Pernambuco, Sergipe e São Paulo. O presidente da entidade registrou ainda que muitos destes professores estavam registrados em carteira profissional, mas não recebiam salários em função das condições das prefeituras. A situação do magistério demonstrava as grandes dificuldades para a universalização da educação e para que se alcançassem patamares de qualidade condizentes com a garantia deste direito. 
A avaliação da CPB integrava uma plataforma específica que não estava restrita às reivindicações dos educadores, indo além ao tratar de diversos aspectos de uma política nacional de educação, sem prejuízo de sua adesão à plataforma do Fórum Nacional em Defesa da Escola Pública na Constituinte o qual integrava. As outras entidades participantes do Fórum construíram dinâmica similar, reforçando suas propostas comuns e apresentando, ao mesmo tempo, as avaliações específicas sobre a situação educacional e propostas nacionais para a Educação envolvendo todas as dimensões da política pública.

Cada uma destas instituições realizou reuniões, assembleias e encontros com diferentes características e dinâmicas, ampliando as condições e a natureza do debate sobre educação, financiamento das políticas públicas, estrutura federativa. $O$ processo de preparação, formulação, diálogo, apresentação das propostas, antes mesmo do final da Constituinte e independentemente de seus resultados, foi uma experiência de organização, aperfeiçoamento da representação e elaboração políticas que permitiu a instituição de alteridade e uma dinâmica de diálogo que marcou uma nova fase de relação com o Estado no Brasil.

Podemos dizer que se instituiu uma esfera pública não estatal que, em meio a inúmeras contradições, tornou possível que as informações, representações, conflitos e negociações se tornassem passíveis de comunicação e conhecimento público. Segundo Raichelis (2005, p.85), para a existência de esferas públicas democráticas é necessário que existam sujeitos sociais dotados de autonomia, capazes de tornar legítimas suas representações.

Na Subcomissão, a dinâmica de trabalho que previu a interação das várias representações com os parlamentares tornou possível que as características políticas e culturais de cada um se tornasse visível e a produção política, a partir da dialética estabelecida, favorecesse distintas formulações junto a seus respectivos partidos, a depender do quanto fossem mais ou menos permeáveis às propostas, a depender da história, do programa, da estrutura e da dinâmica organizativa e do papel de cada um nas estruturas de poder.

As dimensões interativas da experiência configuraram continuidades e descontinuidades dos discursos e propostas em todos os campos, tornando a linguagem também um meio de realização da luta por diferentes concepções e 
sentidos, travando-se assim, no presente, a invenção do futuro. Como afirmou Koselleck (2006, p. 109), os conceitos reúnem uma multiplicidade de significados e sentidos, reúnem em si a diversidade da experiência histórica. A condição polissêmica dos conceitos e noções, no contexto de uma construção político-jurídica como a de uma Constituição, torna o debate um exercício intenso e extenso de definições e redefinições, de movimentação das contradições e representações por parte dos sujeitos das diferentes entidades e partidos, tendo-se como referência os respectivos projetos políticos.

É nesse sentido que se poderia dizer que os direitos, como luta e conquista, significam também uma reinvenção do princípio republicano da coisa pública, o que, na situação brasileira, significa na verdade uma (re)criação da própria República [...] (Telles, 1994, p.102).

Por outro lado, essa experiência fortalece a noção de cidadania associada a "uma estratégia de construção democrática, de transformação social, que afirma um nexo constitutivo entre as dimensões da cultura e da política" (Dagnino, 1994, p.104)

O processo de discussão na Subcomissão desenvolveu-se a partir de um conjunto de contribuições que, na condição de plataformas nacionais, estavam comprometidas com a associação entre transformação social e redemocratização do País. Ainda que algumas das entidades se colocassem na defesa da conservação de determinadas políticas como condição do acesso e controle de fundos públicos, a maioria dos debates transcorreu nesse ambiente de mudança, de grande expectativa quanto às possibilidades de transformação da educação pública.

Ainda no transcorrer das audiências públicas, no dia 11 de maio, o senador João Calmon, no contexto de um debate intenso, apresentou seu relatório parcial com um anteprojeto para a área da Educação, marcado pelas divergências que vinham se expressando no interior da Subcomissão. O Ministro da Educação, Jorge Borhausen, falou aos deputados constituintes na 25a reunião da Subcomissão em 13 mai. 1987 (ANC, 1988b p. 437) reforçando aspectos centrais do relatório e pretendendo influir no debate em relação a aspectos com os quais não tinha concordância.

A apresentação envolveu um balanço das ações do Ministério, compreendendo aquelas voltadas ao ensino básico ( $1^{\circ}$ e $2^{\circ}$ graus), ações de 
alfabetização voltadas a cidadãos com 15 anos ou mais pela Fundação Educar (que nasceu da transformação do antigo Mobral), ao Ensino Técnico e Educação especial, também no âmbito da educação básica e ao Ensino Superior por meio do Programa Nova Universidade. Mereceu destaque a questão do financiamento da educação. Os números apresentados dialogavam com as manifestações das entidades que procuraram indicar como o recurso público financiou as instituições privadas no país.

O orçamento do Ministério da Educação em 1986 (com as suplementações) foi apresentado nos seguintes campos: Emenda Calmon: 24,3 bilhões de cruzados; Salário-Educação (cota-federal): 3 bilhões de cruzados; Salário-Educação (bolsas de estudo): 500 milhões de cruzados; Finsocial (financiador da merenda e do material escolar): 5,8 bilhões de cruzados; outras receitas próprias das universidades, loteria esportiva e outras fontes: 6,7 bilhões, totalizando 41,5 bilhões de cruzados.

Sem pretender levar a efeito uma análise sobre o orçamento do Ministério, não cabível no âmbito deste trabalho, apenas registra-se que, para compreensão das questões envolvidas em relação ao discurso do Ministro sobre a aplicação dos recursos públicos e a execução do orçamento, alguns pressupostos seriam imprescindíveis para a compreensão pública das questões sem que fossem mesclados na apresentação, arrecadação e despesa.

Tendo sido apresentados os valores totais, relativos à vinculação de recursos (13\% previsto na Emenda Calmon) seria necessário, para a compreensão do volume total dos recursos disponíveis, apresentar a arrecadação global da contribuição social do salário-educação, o valor da cota federal (um terço do arrecadado), o valor global destinado à cota estadual (dois terços) e o valor das isenções concedidas às empresas para financiamento de escola própria (para filhos de empregados e outras crianças, jovens e adultos), oferta de bolsas de estudo em escolas da rede privada, indenização de despesas com a escolarização do empregado, em nível do $1^{\circ} \mathrm{grau}$, indenização para os filhos dos empregados, entre sete e quatorze anos, mediante comprovação de frequência em estabelecimentos privados ${ }^{58}$. A mesma questão poderia ser observada em relação às receitas resultantes da Loteria Esportiva e as "outras receitas próprias" das universidades.

${ }^{58}$ Conforme Decreto № 88.374 de junho de 1983 em vigor à época. 
Quanto à aplicação dos recursos, a execução orçamentária tornar-se-ia mais compreensível se estivesse também relacionada às competências do Ministério. Todavia, o Ministro optou por descrever apenas a destinação dos recursos vinculados, por ele denominados recursos da Emenda João Calmon. Aqui estamos tomando, a título de indicação dos problemas, apenas o orçamento executado em 1986, na medida em que a execução do orçamento de 1987 estava em curso, não obstante a previsão de gasto tenha sido apresentada pelo Ministro:

\author{
1986 \\ I Grau, 1,7bilhão \\ II Grau, 2,4 bilhões \\ III Grau 16,7 bilhões \\ Administração 1,7 bilhão \\ Pasep 1,2 bilhão \\ Outros 600 milhões (Ibidem, p. 441)
}

A lista de gastos não revelaria as questões apontadas tanto pelo representante da SBPC quanto pelo da ANPED. O Ministro apontou um conjunto de pontos que deveriam contribuir para o debate e para a elaboração do relatório final do senador João Calmon. Foram eles:

Em primeiro lugar, a educação é um direito de todos e um dever do Estado, mas, também da família e da sociedade. Acho que não podemos deixar de acrescentar esse problema família e sociedade na Constituição brasileira. [...]

Segundo, o ensino básico obrigatório, começando dos 7 aos 14 anos, ou dos 6 aos 14 anos, e gratuito nos estabelecimentos oficiais.

Terceiro, o ensino médio gratuito nos estabelecimentos oficiais para os que demonstrarem efetivo aproveitamento e provarem falta ou insuficiência de recursos.

Quarto, no ensino superior, no meu entender respeitando inúmeras opiniões em contrário, acho que o ensino superior, mantido total ou predominantemente com recursos oficiais dos orçamentos públicos, deve ser gratuito para os que demonstrarem efetivo aproveitamento e provarem a falta ou insuficiência de recursos.

Acho que não podemos deixar de esquecer [sic] de inserir um instrumento que compete ao poder público: a supervisão e a avaliação da qualidade do ensino em todos os níveis.

O Poder Público tem que partir da igualdade de oportunidades, e ela se faz através do acesso e permanência em qualquer nível de ensino, através de programas que suplementem as disponibilidades da família e do educando para que haja realmente justiça social.

Sou a favor do ensino livre, como liberal à iniciativa particular. Vedada a transferência de recursos públicos às entidades que por si 
mesmas, ou através de mantenedoras, tenham a finalidade lucrativa ou que remunerem diretamente ou indiretamente seus dirigentes.

No que diz respeito à vinculação, se tomássemos como base a atual distribuição, diria que $18 \%$ era um valor justo, aquele que acrescentaria o grande trabalho já concretizado na Emenda Calmon.

Mas, temos que prestar atenção no problema da distribuição tributária, porque, se não, podemos fixar um porcentual que seja maior neste momento, mas que será menor no futuro.

Por isso, mais uma vez, coloco a necessidade de se manter o salário-educação como dispositivo constitucional, embora ache e entenda que a sua regulamentação deve promover modificações, ajustes e melhorias. (Ibidem, p. 442, grifo nosso)

A fala do Ministro tornava explícito o compromisso com a política de destinação de verbas públicas para o ensino privado. Seis aspectos se combinaram, traduzindo a perspectiva liberal que orientava as políticas educacionais levadas a efeito por sua gestão à frente do MEC: o primeiro, o de que a Educação, sendo dever do Estado, deveria também ser da família e da sociedade. A partir desta premissa estavam assegurados o direito de a família escolher a escola para seus filhos e, de outro, o direito da sociedade, em particular dos empresários, de manter escolas próprias, oferecer bolsas de estudo para seus empregados e filhos, em escolas particulares, e indenizar despesas realizadas com educação, deixando de recolher a contribuição do Salário-Educação.

O segundo aspecto era o de que tanto o Ensino Médio quanto o Ensino Superior deveriam ser gratuitos nos estabelecimentos oficiais a partir de uma combinação de bom desempenho, com comprovação de insuficiência de recursos. Note-se que o bom desempenho se torna critério para aqueles definidos como pobres e/ou carentes. Pode-se constatar que os demais jovens poderiam ter acesso a estes níveis de ensino recebendo bolsas de estudo, neste caso sem qualquer avaliação.

O terceiro aspecto refere-se a programas que suplementem a família e o educando. Aqui o sentido polissêmico da expressão comportaria tanto programas como merenda e transporte escolar quanto as bolsas de estudo em escolas particulares por meio do salário-educação, validando a liberdade da família e promovendo a igualdade de oportunidades. Vale dizer que nesta direção se situa também a proposta de gratuidade do ensino para todos os portadores de deficiência, 
tornando possível a oferta de bolsas de estudo ou transferência de recursos para as instituições que realizam o atendimento a estas crianças e jovens.

Proibindo a transferência direta de recursos públicos para instituições cujas mantenedoras tivessem fins lucrativos, o discurso a partir de uma negação, defendida por uma parte expressiva das entidades de pesquisa e sindicais que se manifestaram, criava uma contrapartida que legitimava a oferta de vagas nas redes privadas com os fundos públicos. Este quarto aspecto abria espaço para o quinto que o completava, qual seja, o de ampliação da vinculação de recursos para a Educação, de $13 \%$ para $18 \%$, que, assegurado em combinação com distribuição tributária e, diríamos nós, uma política voltada ao crescimento, tornaria viável a oferta gratuita, obrigatória e pública da educação de 7 a 14 anos, bem como o financiamento de bolsas para uma parte expressiva dos estudantes.

Por isso, faria todo o sentido a preservação do salário-educação que, não compondo as receitas sobre as quais incidiria a vinculação, tornava possível que, mesmo limitando-se a transferência direta de recursos para as instituições privadas, se mantivessem as bolsas. A partir deste sexto aspecto, destacamos a afirmação, por parte do Ministro, de que o papel da União, em relação aos Estados e Municípios, deveria ser subsidiário, razão pela qual a Educação deveria ser estadualizada e/ou municipalizada, circunstância que, segundo o Ministro, facilitaria a fiscalização e a avaliação. A mesma representação sobre a intimidade entre os sujeitos no plano local seria aqui novamente evocada.

Depois da apresentação deste conjunto de propostas que, articuladas, permitiam o acesso aos fundos públicos pela iniciativa privada, o Ministro dedicou algumas palavras à valorização do Magistério, indicando a necessidade de que as questões referentes a concursos e carreiras na área pública fossem muito pensadas e debatidas.

A política defendida pelo Ministro pode ser reconhecida quando, na reunião do dia 11 de maio de 1987, dois dias antes de sua manifestação, o relator João Calmon (PMDB-ES), após receber da Mesa da Assembleia Nacional Constituinte um total de 333 emendas, apresentou o relatório à Subcomissão. 


\section{5 - A Constituição inacabada}

O anteprojeto apresentado pelo senador João Calmon (ANC, 1987b), ainda inconcluso, na 23ª reunião da Subcomissão (11 mai. 1987) começava declarando a educação como direito de todos e dever do Estado a ser promovida com a participação da família e da sociedade, mas, diferentemente da Constituição de 1969 (Brasil, 1969c), não subordinando este direito e este dever à garantia da unidade nacional.

Materializava-se o deslocamento, nas letras da lei, do papel da Educação como um dos instrumentos de realização da unidade da Nação (Oliveira, 1995, p.94), representação necessária à sustentação ideológica do Estado ditatorial voltada à promoção da segurança e de um desenvolvimento fortemente identificado com a prosperidade do mercado e com a perspectiva de tornar o Brasil uma potência capitalista em aliança com os EUA. A referida dissociação já se fazia presente no anteprojeto apresentado no Relatório Afonso Arinos (ANC, 1986).

A afirmação de direitos em curso no país ganhava expressão no processo de reorganização, discussão e formulação de políticas por parte de diferentes setores da sociedade que se manifestaram na primeira versão apresentada por João Calmon, em particular, aqueles setores que não tiveram acesso às decisões do Estado durante os governos militares, como os setores dos movimentos sociais urbanos, as Comunidades Eclesiais de Base, o novo sindicalismo urbano - não atrelado à figura do Estado e do dirigente "pelego"- e pouco mais tarde, em 1984, também os sindicatos de trabalhadores rurais, como no oeste de Santa Catarina, sudoeste do Paraná e noroeste do Rio Grande do Sul, ao lado de outras organizações mais moleculares como as dos índios e as dos afro-brasileiros.

A formação deste lastro social importante reforçou o começo da construção de uma nova cultura política que teve como centro as bases para uma vida ao mesmo tempo mais democrática e socializada. Entretanto, no que se refere ao texto sobre a educação, este processo representou uma importante modificação para o fortalecimento do papel do Estado, ainda que de acordo com o anteprojeto fosse delegada à família e à comunidade a colaboração com o dever de educar, 
assegurando-lhes a possibilidade que a partir de suas escolhas 0 Estado assegurasse bolsas de estudo para crianças e jovens.

Ao lado deste, outros aspectos reforçavam a perspectiva de garantia do direito à educação. Os princípios norteadores como liberdade, democracia, bem comum e o repúdio a todas as formas de preconceito e de discriminação contrastavam com a noção liberal de liberdade e solidariedade humana estabelecidas nos princípios da Constituição de 1969. Ao contrário, na Constituinte de 1987, o direito à educação se desprendia do projeto político encetado pelos militares à frente do Estado, ao afirmar que entre as diretrizes da Educação deveriam estar a democratização do acesso e da continuidade dos estudos; o pluralismo de ideias; e a liberdade de pesquisa e de comunicação no exercício do Magistério.

A afirmação das liberdades civis representava uma descontinuidade importante em relação ao legado constitucional deixado pelos militares e seria associada a outra diretriz de vocação democratizante: a "participação adequada, na forma da lei, de todos os integrantes do processo educacional nas suas decisões". (ANC, 1986, p. 52). Essa diretriz foi materializada no texto referente aos municípios com mais de 50 mil habitantes, os quais deveriam organizar conselhos de educação cujos membros seriam eleitos pelo voto popular, direto e secreto, por ocasião das eleições para as câmaras municipais.

Vale reiterar que aos princípios democráticos apresentados se associavam proposições que materializavam o dever do Estado para com a educação pública, como a garantia de ensino fundamental - regular ou supletivo-, sendo que o ensino regular, obrigatório e gratuito para todos deveria ter duração mínima de oito anos, sendo permitida a matrícula a partir dos 6 anos de idade; oferta de vagas em creches e pré-escolas para crianças até 6 anos; e atendimento oficializado e gratuito às pessoas com deficiência e aos superdotados, em todos os níveis de ensino. Em relação ao Ensino Fundamental a definição quanto à obrigatoriedade e a gratuidade não eram asseguradas que a oferta ocorresse em instituições públicas. E quanto às creches e pré-escolas a garantia da oferta, sem qualquer outra especificação, tornava possível que o Estado o fizesse por meio de bolsas de estudo remuneradas com recursos públicos. Ainda em relação ao direito à educação o anteprojeto previa 
que, no caso do Ensino Fundamental, deveria ser assegurado auxílio suplementar ao aluno, de modo a melhorar seu aproveitamento na escola.

Completa a tendência de universalização a definição de que o acesso de todos os brasileiros ao Ensino Fundamental se constituiria em direito público subjetivo, instituto jurídico que permitia a qualquer cidadão acionar o Estado mediante mandado de injunção. ${ }^{59} \mathrm{O}$ texto indicava que os estados e o Distrito Federal organizariam seus sistemas de ensino, sendo que o sistema federal teria caráter supletivo em todo o País, o que, aliás, já constava das constituições de 1967 e 1969. Ficava proposto que a União prestaria assistência técnica e financeira aos sistemas de ensino estaduais o que, aliás, também esteve previsto nas constituições dos governos militares. A diferença fundamental na proposta da Constituinte é que, neste caso, este papel teria como foco e prioridade o atendimento da escolaridade obrigatória.

Por outro lado, o relatório criava condições para municipalização da educação, na medida em que indicava que os estados transfeririam aos municípios as obrigações afetas à educação pré-escolar e ao $1^{\circ}$ grau, sempre que esses alcançassem condições técnicas e financeiras suficientes. Os municípios, por sua vez, só poderiam atuar em outros níveis de ensino quando o Ensino Fundamental estivesse satisfatoriamente atendido. O texto previa ainda que a lei deveria estabelecer sanções jurídicas para o não cumprimento dos dispositivos previstos.

A municipalização foi identificada com a descentralização, em sintonia com várias das manifestações na Subcomissão de Educação, Cultura e Esportes sendo que o anteprojeto previa, diferentemente das Constituições de 1967 e 1969, que uma lei complementar deveria estabelecer padrões mínimos de eficiência escolar. Esse conjunto de aspectos parece explicar o significado da ênfase tão grande dada ao tema da municipalização da educação. Não se tratava de simples descrições de características objetivamente encontradas.

Observe-se que o texto se estrutura em duas direções: por um lado a garantia do direito e das liberdades civis no campo da educação e, por outro, estabelecia um

59 Mandado de Injunção é [...] um instituto processual civil, outorgado ao legítimo interessado como remédio constitucional para a obtenção, mediante decisão judicial de equidade, a imediata e concreta aplicação de direito, liberdade ou prerrogativa inerente à nacionalidade, à soberania popular ou à cidadania, quando a falta de norma reguladora torne inviável o seu regular exercício. (Oliveira, 1995, p.114) 
circuito de artigos que inter-relacionados favoreciam a destinação de fundos públicos à iniciativa privada. Três artigos se articulavam nessa direção. $O$ primeiro, definindo a liberdade do ensino à livre iniciativa privada observadas as disposições legais; o segundo determinava que a lei regulasse a transferência de recursos públicos às instituições privadas que prestassem relevantes serviços públicos.

Note-se que a prestação de relevantes serviços públicos se assemelhava à definição apresentada pela Federação Nacional dos Estabelecimentos de Ensino FENEN. Sem qualquer indicação de procedimentos legais de tipificação da relevância, o parágrafo único estabelecia que as instituições referidas fossem organizadas por comunidades e grupos de caráter social, religioso e cultural, além de indicar a necessária comprovação de não distribuição de lucros e reaplicação de eventuais excedentes em educação com apresentação de contabilidade aberta e verificável. Os princípios apontados indicavam que, possivelmente, as instituições confessionais estariam habilitadas para receberem tais recursos. Em relação às demais instituições privadas, os mecanismos de transferência de recursos não se mostravam de maneira tão evidente.

Já o terceiro artigo, sem citar o salário-educação, recuperava a ideia de uma contribuição tributária, com texto muito semelhante ao da Emenda Constitucional no 1 de 1969 (ANC, 1987b):

As empresas comerciais, industriais e agrícolas são obrigadas a
manter o ensino fundamental gratuito de seus empregados e filhos
destes, entre os seis e os catorze anos, ou a concorrer para aquele
fim mediante contribuição tributária, na forma que a lei estabelecer.
[...] As empresas comerciais e industriais são ainda obrigadas a
assegurar, em cooperação, condições de aprendizagem a seus
trabalhadores menores e promover o preparo do seu pessoal
qualificado. (Ibidem, p. 26)

A expansão do direito à educação por meio do dever do Estado se combinava com a liberdade da iniciativa privada atuar na área educacional, tendo para isso acesso aos recursos públicos. Para tanto a ampliação da vinculação de recursos era fundamental. Neste contexto, o relator propôs que a União aplicasse $18 \%$ e os Estados, o Distrito Federal e os municípios, 25\%, no mínimo, da receita resultante de impostos, inclusive as provenientes de transferências, na manutenção e desenvolvimento do ensino. Para tanto estabeleceu que devessem estar excluídos desses valores o auxílio suplementar aos educandos. 
$O$ relator indicaria ainda o estabelecimento de prioridade para o ensino obrigatório no que se refere à repartição de recursos públicos, apontando que uma lei complementar definiria, plurianualmente, a porcentagem dos recursos a serem investidos por cada um dos entes federados. A proposta do relator foi intensamente discutida pela Subcomissão, destacando-se duas manifestações, a de Florestan Fernandes (PT) e a de Octávio Elísio (PMDB).

Florestan Fernandes, na reunião da Subcomissão de 14 de maio de 1987, (ANC, 1988b, p.459-60) considerando a proposta pobre e pouco dignificante ressaltou que o relator se colocava mais como agente do Governo do que do processo percorrido pela Subcomissão. Na reunião de 18 de maio do mesmo ano (Ibidem, 469-70), seu discurso foi ainda mais contundente na defesa das verbas para a escola pública. Na mesma direção o deputado Octávio Elísio, em 14 maio, reivindicou que fosse feita uma reflexão política sobre a situação da Educação que expressasse o trabalho da Subcomissão. (Ibidem, p. 462-63)

Na reunião da Subcomissão de 19 de maio a ANPED apresentou documento que expressava a posição dos educadores presentes na $X$ Reunião Anual realizada entre 12 a 15 de maio, na cidade de Salvador (Brasil, 1988b, p. 497-9). Ao reconhecer o esforço do relator, no sentido da universalização do ensino público fundamental, apontou a necessidade de que a gratuidade fosse estendida para os demais níveis de ensino, tornando imprescindível a exclusividade de verbas públicas para a escola pública. Também destacou que a laicidade deveria se constituir em valor fundamental da escola pública, como teria sido para os fundadores da República e que os princípios democráticos deveriam nortear a elaboração, execução e controle da política educacional. Por fim, destacava a imprescindibilidade de a nova Constituição apontar para uma nova Lei de Diretrizes e Bases da Educação Nacional.

Em 20 de maio se manifestou a União Nacional dos Estudantes reivindicando verbas públicas para a escola pública. Em 22 de maio de 1987, foi apresentado novo anteprojeto votado em 23 de maio. A votação fez prevalecer o destino dos recursos públicos para a escola pública, mas o debate e o conflito tiveram maior densidade na Comissão da Família, da Educação, Cultura e Esportes, da Ciência e Tecnologia e da Comunicação. Presidida por Marcondes Gadelha (PFL-PB), e tendo como relator Artur da Távola (PMDB-RJ) a Comissão contou com 62 integrantes. (Anexo G) 
Cinco dias depois, no dia 28 de maio de 1987, o relator João Calmon apresentou na Comissão da Família, da Educação, Cultura e Esportes, da Ciência, de Tecnologia e da Comunicação os principais aspectos do anteprojeto. Suas palavras mostravam o intuito de restabelecer a negociação com os parlamentares de centro e de direita, representantes do setor privado.

O conteúdo dos debates na Subcomissão e sua versão final produzida pelo relator João Calmon envolveram a relação entre liberdade de ensino e acesso aos fundos públicos pelos entes privados. Uma das razões de não ter sido votado um anteprojeto para a Comissão de Sistematização diz respeito ao debate em relação ao papel do ensino privado. Este artigo foi objeto de intensa discussão na Comissão de Sistematização e no Plenário e esteve na origem da crise com o chamado Centrão.

Compreender as razões do dissenso impõe recuperar a trajetória da formulação desde o final dos trabalhos da Subcomissão de Educação. Depois do amplo debate realizado com a participação de vários sujeitos da sociedade, a votação realizada estabeleceu que o artigo $7^{\circ}$ teria a seguinte redação: $O$ ensino é livre à iniciativa privada, observadas as disposições legais, sendo proibido o repasse de verbas públicas para criação e manutenção de entidades de ensino particular. (Ibidem, p. 565) No mesmo texto do anteprojeto o artigo 11 afirmaria que:

A União aplicará, anualmente, nunca menos de dezoito por cento, e os Estados, o Distrito Federal e os Municípios, vinte e cinco por centro, no mínimo, da receita resultante de impostos, inclusive os provenientes de transferências. (Ibidem, p. 565-6)

Como no artigo 11 não havia sido feita referência a que a aplicação dos recursos vinculados fosse no ensino público, mas ao ensino de forma geral, quando o debate teve início na Comissão VIII e João Calmon fez a apresentação do anteprojeto e explorou a aparente contradição entre os dois artigos:

Em relação ao artigo 11, houve uma outra redação que foi submetida à votação da nossa subcomissão, de autoria do eminente Presidente Hermes Zanetti (PMDB-RS). No texto proposto pelo presidente da nossa Subcomissão, a parte final receberia um acréscimo de um adjetivo, inclusive os provenientes de transferências na manutenção e desenvolvimento do ensino, o nobre Presidente da Subcomissão acrescentava do ensino público [grifo nosso]. Posta em votação estou dando estes detalhes, por que aqui há membros das outras duas Subcomissões que não conhecem os detalhes da nossa 
Subcomissão - S.Ex ${ }^{\underline{a}}$ acrescentava a palavra público, enquanto que no meu texto, que repetia Ipsis litteris, os textos das constituições de 1934 e 1946, se referia apenas à manutenção e desenvolvimento do ensino, sem especificar público ou privado. Surgiu, portanto, um conflito entre dois artigos; porque 0 art. $7^{\circ}$ do anteprojeto do Relator, tinha o seguinte texto: "O ensino é livre à iniciativa privada, observadas as disposições legais".

A Subcomissão entendeu, na sua alta sabedoria, aprovar uma emenda da nobre constituinte Abigail Feitosa, acrescentando mais essas palavras ao artigo que ficou com esse texto completo:

Art. $7^{\circ} \mathrm{O}$ ensino é livre à iniciativa privada, observadas as disposições legais, sendo proibido o repasse de verbas públicas, para criação e manutenção de entidades de ensino particular.

Então obviamente, 0 art. $7^{\circ}$ entra em conflito com 0 art.11, que se refere à destinação de verbas públicas para o ensino em geral sem exclusividade para o ensino público. Admitindo, portanto, também a destinação de verbas para entidades que estavam contempladas no art. 15 do anteprojeto do relator, impondo uma série de exigências para algumas entidades particulares receberem verbas públicas. Foi o texto do art. 15 que não chegou nem sequer a ser votado na Subcomissão, através de um acordo de cavalheiros, - que muito honra nossos colegas que integraram esta Subcomissão [...]. (ANC, 1988a, p. 42-3)

João Calmon retomou sua proposta - não votada na Subcomissão - no contexto de uma manifestação que nitidamente desaprovava a votação ocorrida. A retomada de sua emenda na apresentação do anteprojeto constitui uma clara tentativa de retomar a negociação com os representantes dos setores privatistas pois, nesta fase, seria no âmbito dos acordos parlamentares que se pretendia resolver a questão. O relator continuou:

Art. 15. A lei regulará a transferência de recursos públicos a instituições educacionais privadas, que prestam relevantes serviços públicos.

Parágrafo único: As instituições a que se refere o caput deste artigo: a) serão organizadas por comunidades e grupos de caráter social, religioso e cultural

b) comprovarão a não distribuição de lucros, a reaplicação de eventuais excedentes em educação, e apresentarão contabilidade aberta e verificável pela comunidade e pelo poder público.

Através de um acordo de cavalheiros não foi nem sequer votado esse artigo, porque a Subcomissão, através desse acordo, que a nível de Comissão Temática ou de Comissão de Sistematização seria apresentado uma proposta introduzindo 0 artigo nas disposições transitórias, contemplando por algum tempo, não ainda especificados, 5,10 ou 15 anos, estas poucas entidades, do setor privado, universidades confessionais, como a Pontifícia Universidade Católica, na área católica, da Universidade Mackenzie, na área 
evangélica, a Universidade Metodista de Piracicaba que são, sem dúvida nenhuma, entidades de um mais alto nível e que, no seu conjunto abrigam 250 mil estudantes, e o que temia o Relator, ao elaborar o seu trabalho, é facilmente compreensível. Se eventualmente entrassem em colapso essas universidades católicas e evangélicas, e a PUC de São Paulo, que outro dia foi socorrida com um empréstimo de 76 milhões de cruzados, pela Caixa Econômica Federal, com recomendação de prioridade do Ministério da Educação e do Ministério da Cultura já estariam fechadas.

Então, mais de 250 mil alunos na área do ensino superior, no setor público, representaria uma tremenda pressão, e todo o dinheiro federal para a educação, não bastaria para o terceiro grau, e haveria um grave e irremediável dano para $87 \%$ das crianças deste País, que não completam o ensino fundamental, que hoje, no Brasil, tem 8 anos de duração. Foi esse o único objetivo que inspirou o Relator ao propor a aprovação desse art.15" (Ibidem, p. 43)

Esta declaração, reconhecendo a participação estrutural do ensino privado na oferta de vagas no País, toma como certo que a existência da ação empresarial dependeria dos recursos do Estado. A ausência de uma análise sobre a situação das mantenedoras além de propostas que previssem a transição, mesmo que de longo prazo, para que as instituições pudessem se tornar autossustentáveis ou fossem assumidas pelo Estado (Nadai, 1986 p. 231) denotam que a política expressa na proposta era efetivamente de aportar recursos públicos para o setor privado.

O argumento, ao opor a garantia de ensino fundamental obrigatório ao atendimento do Ensino Superior ignorava possibilidades de transição, aumento e planejamento de investimentos por parte do Estado brasileiro, capaz de permitir que o modelo herdado do período militar fosse devidamente superado.

Questionado, entre outros, pela professora Vanilda Paiva - na qualidade de convidada para a oitava reunião ordinária da Comissão VIII (03 jun. 1987) -, Calmon analisou a relação público e privado, a partir de uma perspectiva sociológica:

As forças privadas que se aplicam em áreas como educação, não são forças, digamos assim, comprometidas com a produção propriamente, quer dizer, não são áreas que geram riquezas; são áreas que, primeiro oneram a população para que ela possa obter alguma educação; em segundo lugar oneram o Estado, porque passam a depender do subsídio do Estado. Do meu ponto de vista, a educação pública, apesar de todos os argumentos que têm sido colocados agora em cima da mesma, muitos dos quais quantitativamente falaciosos não são argumentos com pesos suficientes para que o nosso sistema continue sendo um sistema 
altamente privatizado. Acho que no rastro dessa discussão existem algumas outras que certamente se tornarão muito quentes na discussão da Constituinte, mormente aquela que diz respeito à tentativa de definir o público como privado [...]

[...] gostaria de apoiar aqui a iniciativa dos Constituintes Hermes Zaneti e Octávio Elísio no sentido de que nas disposições transitórias da nova Constituição, haja espaço para uma espécie de programa de emergência que vá até o ano 2000, no sentido de que permita não só a ampliação, mas a recuperação do nosso sistema de ensino de uma maneira rápida e inteligente. (ANC, 1988a, p.124)

Suas palavras deixam clara a perspectiva de que a Constituição abrisse campo no Brasil para superação da política - fortemente acentuada pelos militaresde privatização da Educação por meio de um processo de transição que fortalecesse o sistema público de educação. E foi este o sentido dos substitutivos apresentados pelo relator na Comissão VIII, que se constituindo referência para o debate se diferenciou na medida em que declarava que a iniciativa privada não sofreria ingerência do Poder Público, exceto para fins de supervisão. $\mathrm{O}$ artigo 10 definia: "O ensino é livre à iniciativa privada, que ministrará sem ingerência do Poder Público, salvo para fins de supervisão de qualidade”. (ANC, 1987c, p. 3)

O artigo 11 estabelecia que fosse assegurada exclusividade de utilização das verbas públicas para o ensino público. O repasse de verbas públicas para as escolas comunitárias, filantrópicas ou confessionais seria admitido desde que estas, conforme o parágrafo $1^{\circ}$ prestassem gratuitamente os seus serviços, podendo receber, na forma da lei, auxílio do Poder Público e de entidades públicas e da iniciativa privada. Além dessa premissa, o relator introduziu um dispositivo voltado ao controle público de tais instituições, a saber: as escolas deveriam ser administradas em regime de cogestão pelos integrantes e pela comunidade, conforme o parágrafo $2^{\circ}$. Além disso, deveriam também, segundo o item "b" do parágrafo $2^{\circ}$, comprovar finalidade não lucrativa, bem como a reaplicação de excedentes em educação. Por sua vez, O item "c" definia que em caso de encerramento das atividades, o patrimônio da instituição deveria ser destinado a outra escola comunitária ou ao Poder Público.

No primeiro Substitutivo elaborado pelo relator Artur da Távola o artigo 10 manteve basicamente a redação anterior, acrescentando-se que a "ingerência" do Poder Público estaria circunscrita à autorização, reconhecimento e credenciamento 
de cursos e supervisão da qualidade. Por sua vez, o artigo 11 mudava o anterior, ampliando as condicionantes para acesso ao Fundo Público. Definia:

É assegurada a exclusividade de utilização das verbas públicas para o ensino público.

$\S 1^{\circ} \mathrm{Na}$ insuficiência de ofertas na rede pública, as escolas comunitárias, filantrópicas ou confessionais poderão receber, na forma da lei, auxílio do Poder Público.

$\S 2^{\circ}$ As escolas mencionadas no parágrafo anterior merecerão o estímulo financeiro do Poder Público se:

a - aprovarem finalidade não lucrativa e reaplicarem eventuais excedentes financeiros em educação;

b - previrem a destinação de seu patrimônio a outra escola comunitária, filantrópica, ou confessional ou ao Poder Público, no caso do encerramento de suas atividades;

c- forem administradas em regime de participação, pelos integrantes do processo educacional e pela comunidade. (ANC, 1987d, p. 3)

Duas mudanças merecem registro: o acesso ao fundo público mediante constatação de insuficiência de vagas em instituições públicas, caso em que não havia nenhuma indicação da natureza transitória da definição que previsse, por exemplo, o planejamento do atendimento pelo Estado, no Plano Nacional de Educação. A segunda mudança se refere ao substitutivo do relator que ganhou nova redação sem nenhuma alteração dos artigos 10 e 11. Estes substitutivos, entretanto, foram derrotados na Comissão VIII pelos parlamentares de centro-direita que, a partir da derrota dos substitutivos do relator tentaram aprovar emendas de seus interesses. Porém, não houve acordo com os demais parlamentares, identificados com o espectro de centro-esquerda.

Sob a pressão opaca da FENEN junto aos parlamentares e sem mobilização, participação e reflexão crítica da maioria dos setores que se expressou na Subcomissão, o processo se inverteu:

Formou-se uma aliança entre os constituintes ligados aos meios de comunicação, os representantes das empresas de ensino e os evangélicos. Esses grupos se uniram para combater a exclusividade, a formação de um Conselho Nacional de Comunicação e a criação da reserva de mercado. Nessa aliança, a posição dos evangélicos, interessados na área de educação e das comunicações, foi decisiva porque constituíam uma bancada de doze parlamentares que representavam a maioria da Subcomissão da Família, do Menor e do Idoso. (Pinheiro, 2005, p. 272) 
Durante as discussões dos substitutivos foram produzidas 1.921 emendas dos demais Constituintes, das quais 1.047 referentes aos Anteprojetos das Subcomissões e 874 ao primeiro Substitutivo do Relator. Destas, foram acolhidos 747 Pedidos de Destaque para emendas e partes dos Substitutivos. O último Substitutivo foi derrotado, sendo 37 votos contrários e 26 favoráveis. Em seguida foi votado o primeiro Substitutivo, também derrotado por igual número de votos. Então, o presidente Marcondes Gadelha (PFL-PB) colocou em votação as emendas, mas o Plenário recusou-se a votar. Assim, enviou em 16 jun. 1987 à Comissão de Sistematização um conjunto de anexos e uma proposição subscrita por 37 Constituintes membros da Comissão.

Com sucessivos atos anti-democráticos e demagógicos, típicos de sociedades autoritárias, os seus apoiadores tentaram, em vão, fazer suas ideias prevalecerem, contrárias às aspirações da maioria do Povo Brasileiro, que representamos.

Solicitamos a Vossa Excelência que transmita à Comissão de Sistematização as posições da maioria desta Comissão, que cumpre assim o seu dever de exprimir a vontade majoritária da Nação Brasileira, nos campos a cujo estudo nos dedicamos.

Não aceitamos a elitização da Escola Brasileira, criando escolas para ricos e escolas para pobres.

Não queremos fechar a escola privada de excelência para as crianças carentes. Defendemos os direitos que têm as famílias pobres de também terem seus filhos em escolas confessionais, se 0 desejarem. Por essas razões, não aceitamos que tais escolas sejam marginalizadas quando se utilizam de verbas públicas. Queremos os veículos livres para que a opinião pública seja bem informada em uma democracia pluralista.

Recusamos a censura em qualquer de suas formas, mas defendemos o direito que têm as famílias de bem educar seus filhos, devendo-se por isso, exercer vigilância sobre programas de televisão.

Fique, pois, tranquila a Sociedade Brasileira. A maioria de seus representantes, de diferentes correntes partidárias, está coerente e fiel àquelas que são suas maiores aspirações [...]. (ANC, 1987f, p. 56)

Impelido pela disputa política, o discurso se mostra sem qualquer pretensão de ressignificar o sentido do que é público. A representação constrói simplificações importantes que se entrelaçam. Ao reduzir o público ao que é ruim e o privado ao que é bom, a imagem das crianças pobres ganhava todo sentido, reatando os laços com as noções de direito e justiça. 
Com efeito, o prenúncio do fim dos binômios escola privada e escola pública carente e escola privada e elites era apresentado como consequência da mobilidade dos sujeitos com os fundos públicos, reforçando a imaginada ascensão social por meio da educação. Era esta consciência e compreensão que pretendiam universalizar e tornar capilar na Comissão de Sistematização.

A clareza de objetivos em relação aos recursos públicos se manifestou também no anteprojeto encaminhado pelo presidente da Comissão VIII que, reorganizando e redefinindo os artigos tornava possível o acesso aos recursos vinculados (cuja possibilidade de serem elevados para $18 \%$, àquela altura, era grande) e o acesso aos recursos do salário-educação.

Art. 8 - A União aplicará anualmente nunca menos de dezoito por cento, e os Estados, o Distrito Federal e os Municípios, vinte e cinco por cento, no mínimo, da receita resultante de impostos, inclusive os provenientes de transferência, na manutenção e desenvolvimento do ensino. [...]

$\S 5^{\circ}$ As escolas comunitárias, filantrópicas ou confessionais, sem finalidades lucrativas, poderão receber, na forma da lei, verbas do Poder Público e de entidades públicas e da iniciativa privada.

$\S 6^{\circ}$ As escolas mencionadas no parágrafo anterior merecerão estímulo financeiro do Poder Público se:

a) administradas, em regime de participação, pelos integrantes do processo educacional e pela comunidade;

b) Comprovarem finalidade não lucrativa e reaplicarem eventuais excedentes na Educação;

c) Previrem a destinação do seu patrimônio a outra escola comunitária, filantrópica ou convencional ou ao Poder Público, no caso de encerramento de suas atividades. [...]

Art. 10 - O ensino é livre à iniciativa privada, que o ministrará sem gerência do Poder Público, salvo para fins de autorização, reconhecimento e credenciamento de recursos e supervisão da qualidade.

Art. 11 - As autarquias, fundações e empresas comerciais, industriais e agrícolas, que não mantiverem escolas próprias ou não concederem bolsas de estudo para matrícula de seus empregados e respectivos dependentes no pré-escolar e no primeiro grau, deverão recolher o salário educação, na forma da lei.

$\S 1^{\circ}$ - Os recursos a que se refere o caput deste artigo destinam-se à expansão da oferta do ensino público e, em casos especiais de escolas comunitárias, filantrópicas ou confessionais, nos termos do artigo $8^{\circ}$ e seus parágrafos.

$\S 2^{\circ}$ - As empresas que mantiverem escolas, ou custearem sob qualquer forma os estudos de seus empregados ou de seus filhos, 
poderão descontar as despesas de recolhimento do salário educação, na forma da lei. (Ibidem, p. 12-3, grifos nossos)

A organização e conteúdo dos artigos conformam uma divisão racional das fontes de recursos entre os chamados setores privatistas, de tal sorte que a lei permitiria que as escolas filantrópicas, confessionais e comunitárias, mediante um conjunto de critérios, pudessem receber recursos públicos. Já as escolas particulares, sem nenhum critério, os receberiam por meio de bolsas de estudo, pois tomariam a forma de isenção fiscal. As empresas que tivessem escolas ou ofertassem bolsas de estudo, conforme seus interesses estariam isentas do pagamento da contribuição do salário-educação.

$\mathrm{O}$ anteprojeto apresentado na fase $\mathrm{H}$ tornava clara a estratégia dos setores empresariais, no contexto da produção, dos dissensos e conflitos havidos até então, desde a instalação das Subcomissões.

Findos os trabalhados da Comissão VIII as atenções se voltaram para a Comissão de Sistematização, que teve como presidente Afonso Arinos (PFL-RJ) e como relator Bernardo Cabral (PMDB-AM), tendo sido instalada em 09 de abril de 1987 e concluído seus trabalhos em 18 de novembro do mesmo ano, depois de 22 reuniões ordinárias e 32 reuniões extraordinárias (Anexo L). O trabalho se apoiou na produção das 24 Subcomissões agrupadas em oito Comissões Temáticas que além de respeito ao processo de discussão e ao Regimento Interno ${ }^{60}$ revelou-se também como estratégia para negociação, pois a Comissão de Sistematização tinha perfil mais progressista que a maioria do Plenário, identificado com a chamada centrodireita (Pinheiro, 2005 p.274). O relator apresentou um projeto de Constituição em 29 de junho de 1987 que recebeu 20.770 emendas de Plenário.

No caso da Educação, como a Comissão temática VIII não aprovou um anteprojeto, caberia ao relator da Comissão de Sistematização, de acordo com o regimento interno, elaborá-lo, o que fez ouvindo os relatores João Calmon e Artur da Távola, procedimento muito criticado por parlamentares como a deputada Sandra Cavalcanti (PFL-RJ).

\footnotetext{
60 "§ $4^{\circ} \mathrm{Na}$ hipótese de alguma Comissão não apresentar seu trabalho no prazo estipulado no parágrafo anterior, caberá ao Relator da Comissão de Sistematização a elaboração do mesmo, obedecido o prazo estabelecido no caput do art. 19." (ANC, 1987a, art. 14, § $4^{\circ}$ )
} 
O primeiro substitutivo apresentado pelo Relator, em 26 de agosto de 1987, foi objeto de discussão em oito audiências públicas de 26 de agosto a 04 de setembro de 1987, recebendo 14.320 emendas entre 31 de agosto e 05 de setembro. Ao se dirigir a Afonso Arinos, presidente da Comissão de Sistematização, apresentou o Anteprojeto da Comissão (Fase I) ${ }^{61}$, em 26 de junho de 1987.

\begin{abstract}
A vista do notório impasse que marcou, de forma duvidosa, o fim dos trabalhos da Comissão da Família, da Educação, Cultura e Esportes, da Ciência e Tecnologia e da Comunicação, ainda uma vez o relator preferiu adotar alternativa que não suprimisse ou mutilasse o amplo debate que a matéria mereceu. Por isso pareceu-lhe, próprio, em interpretação construtiva, da regra insculpida no parágrafo $4^{\circ}$, do artigo 14, do Regimento Interno da Assembléia Nacional Constituinte, aproveitar ao máximo, os trabalhos da referida Comissão abrindo-se a possibilidade agora, nesta Comissão de Sistematização, da formulação de emendas que efetivamente possam traduzir a vontade popular, se divergentes do que ora aqui se consigna. (ANC, 1987h, p. 2)
\end{abstract}

Ao considerar inadequada a utilização do anteprojeto do relator Artur da Távola da Comissão VIII a deputada Sandra Cavalcanti (PFL- RJ), na reunião da Comissão de Sistematização de 09 de julho de 1987, manifestando sua discordância em relação ao anteprojeto de Bernardo Cabral, Sandra Cavalcanti proferiu as seguintes palavras:

Essa generosidade mantida já veio do substitutivo do meu nobre colega, meu caro amigo Artur da Távola, já veio no primeiro substitutivo, passou no segundo e foi objeto de vários debates; essa generosidade - na destinação das verbas públicas, com exclusividade só para as entidades públicas [...] (ANC, 1987g, p. 197)

Uma vez mais o debate sobre os recursos públicos para as escolas privadas era trazido para o centro dos trabalhos. A deputada pretendia retirar do texto, por meio de emenda, a referência à excepcionalidade da destinação de recursos, posto que a redação do primeiro substitutivo do relator previa que: "Os recursos públicos serão destinados às escolas públicas, podendo nas condições de lei e em casos excepcionais, ser dirigidos a escolas confessionais, filantrópicas ou comunitárias, desde que: [...]". (Anexo N, p. 341) ${ }^{62}$

\footnotetext{
${ }^{61}$ A partir de então, se sucederiam seis outras fases (Anexo E).

${ }^{62}$ Para facilitar o trabalho dos leitores, ao nos referirmos ao Anexo $\mathrm{N}$, indicaremos as páginas da obra original de onde foi extraído (Lima; Passos; Nicola, 2013), uma vez que elas constam na reprodução que utilizamos.
} 
Em 19 de setembro de 1987, o relator apresentou o segundo substitutivo que considerou, além destas emendas, mais 86 emendas populares (Farenzena, 2001, p.106)

Ao examinar os dois Substitutivos a partir do Anteprojeto de Constituição apresentado, parece explicitar-se que houve a intenção de Bernardo Cabral, conforme indicou Pinheiro, em preservar algumas das conquistas, tanto do projeto da Subcomissão quanto dos anteprojetos derrotados na Comissão VIII. Leia-se:

A intenção do relator foi resguardar os dispositivos aprovados no
anteprojeto da Subcomissão e as contribuições do relator da
Comissão Temática 8. Nos três anteprojetos apresentados pela
Sistematização, a educação seguiu a orientação política geral: o
primeiro retratava, com exceção da exclusividade, as resoluções
aprovadas na Subcomissão; o segundo foi mais para a direita,
cedendo a pressões do Centrão; e o terceiro retomou o equilíbrio das
decisões anteriores. (Pinheiro, 2005, p.275)

A partir da apreciação das atas e dos substitutivos é possível entrever que, ao retirar uma série de definições consolidadas até então, o relator pretendia criar condições de negociação com os setores de centro de direita. Vejamos as modificações.

O artigo 233 do Substitutivo 2, no qual foi inserida a referência ao repúdio a todas as formas de discriminação, já prevista na versão final do anteprojeto da Subcomissão.

A educação, direito de cada um, e dever do Estado, será promovida
e incentivada com a colaboração da família e da comunidade,
visando ao pleno desenvolvimento da pessoa e ao seu compromisso
com o repúdio a todas as formas de preconceito e discriminação
(grifo nosso). (Anexo N, p. 334).

O relatório da Subcomissão e o Substitutivo $\mathrm{F}$ (ANC, 1987e) já apresentavam formulações nessa direção. Outra modificação se referiu à inclusão no item $V$ do parágrafo único do artigo 233, do concurso de ingresso e carreira para o Magistério. Os princípios enunciados neste item já estavam presentes na proposta final da Subcomissão e nos Substitutivos apresentados no âmbito da Comissão de Educação, sofrendo modificações no Substitutivo I da Comissão de Sistematização. 
Para a execução do previsto neste artigo, serão obedecidos os seguintes princípios:

V - valorização dos profissionais de ensino, obedecidos padrões condignos de remuneração e garantindo-se em lei critérios para a implantação de carreira para 0 magistério, com 0 ingresso exclusivamente por concurso público de provas e títulos. (Anexo N, p. 335)

O Substitutivo I não fez referência a outros dois princípios que seriam inseridos no artigo 233 no Substitutivo II. O primeiro princípio configurava o parágrafo único do artigo e o segundo, como inciso I do parágrafo único, estabelecia que:

I - Democratização do acesso e permanência na escola [...]

VI - Gestão democrática do ensino, com participação de docentes, alunos, funcionários e representantes da comunidade. (Idem, p. 3345)

Em relação às Universidades, no Substitutivo II, a referência à autonomia econômica foi suprimida do texto, além de ter sido retomado o princípio de indissociabilidade entre pesquisa e ensino sem referência a extensão, presente na versão final do projeto da Subcomissão e no substitutivo da fase $\mathrm{H}$.

As universidades gozam de autonomia didático-científica, administrativa e de gestão financeira e patrimonial nos termos da lei. O ensino superior nas universidades far-se-á com observância ao princípio da indissociabilidade entre ensino e pesquisa. (Idem, p. 336).

No inciso I do artigo 234 foi retomada a formulação, já presente no substituto das fases $\mathrm{F}$ e $\mathrm{H}$ da Comissão VIII, que reinseria no texto a definição de que o Ensino Fundamental seria obrigatório e gratuito, inclusive para aqueles que a ele não tiveram acesso em idade própria. (Idem, p. 336). Esta formulação também não estava presente no Substitutivo I. Seu retorno ao anteprojeto tratava de assegurar que o direito fosse extensivo ao conjunto dos cidadãos e não apenas às crianças entre 7 a 14 anos.

Também foi inserido o inciso II que assegurava: "extensão do ensino obrigatório e gratuito progressivamente ao Ensino Médio" (Idem, p. 336) retomando aspectos do Substitutivo aprovado na Subcomissão e o conteúdo do Substitutivo $F$ não aprovado pela Comissão VIII. 
Em relação à questão do atendimento às pessoas com deficiências a mudança do segundo substitutivo foi relevante, pois previa "atendimento educacional especializado aos portadores de deficiências, preferencialmente na rede regular de ensino" (Idem, p. 336). Até então esta formulação não tinha sido produzida em nenhuma das versões. O primeiro Substitutivo elaborado pelo relator Artur da Távola na Comissão VIII previa, no inciso IV do artigo 3o, a garantia de educação gratuita aos deficientes e superdotados (ANC, 1987c, p. 2), além de um direito se constituía em possibilidade de recursos públicos pelas instituições que atendiam pessoas com deficiência no País. A garantia de atendimento na rede pública representava um direito não assegurado em outra Constituição do Brasil. Vale observar que nos dois substitutivos se mantiveram as formulações relativas ao "atendimento em creches e pré-escolas às crianças de zero a seis anos de idade". (Anexo N, p. 336)

Ainda no artigo 234 , houve modificação em relação ao inciso que tratava da mesma questão nos substitutivos anteriores. A versão final do anteprojeto da Subcomissão e as versões da Comissão VIII previam que sendo o Ensino Fundamental direito público subjetivo, o Estado quando do não cumprimento, seria acionável por mandado de injunção. Ao final dos trabalhos da Comissão de Sistematização se verificavam alterações na redação do artigo 234 , como no Substitutivo 2 da Comissão de Sistematização em que foi retirada a referência ao mandado de injunção, passando a ter a seguinte forma: o "não oferecimento do ensino pelo Estado, ou a sua oferta regular, importa em responsabilidade das autoridades competentes" (Idem, p.337). A mudança passava a indicar a responsabilização do ente público sem, contudo, a garantia de um instrumento jurídico para fazer valer as responsabilidades do Estado.

No que toca ao ensino religioso a redação do parágrafo $2^{\circ}$ artigo 236 mudou a definição, sendo que deixando de ser disciplina facultativa passou à condição de disciplina a ser oferecida em horários normais da escola pública passando, então, a matrícula a ser facultativa. (Idem, p. 338). A mudança pretendia incorporar parcialmente as sugestões realizadas no âmbito da Comissão de Sistematização, em particular, pela deputada Sandra Cavalcanti (PFL-RJ), que defendia a oferta do ensino religioso, "como antiga aspiração do povo brasileiro", também nas escolas de 2ํㅡ Grau e Instituições Públicas de Ensino Superior, nestes casos como disciplina facultativa. (ANC, 1987g, p. 196) 
O texto do Substitutivo I indicava em seu caput que a "União, os Estados, o Distrito Federal e os Municípios organizarão em regime de colaboração, os seus sistemas de ensino." (Anexo N, p. 339). Esta redação se manteve no artigo 237 do Substitutivo II.

Em relação aos sistemas de educação a redação se tornaria mais precisa e específica. No Substitutivo I o parágrafo $1^{\circ}$ indicava que: "A União organizará o sistema federal e dos Territórios tendo caráter supletivo em relação aos demais entes federados nos limites das deficiências locais." (Idem, p. 339)

O mesmo parágrafo no Substitutivo 2 passou a ter a redação anteriormente prevista nos anteprojetos $\mathrm{F} \mathrm{e} \mathrm{H}$ da Comissão VIII.

A União organizará e financiará o sistema federal de ensino e dos Territórios, e prestará assistência técnica e financeira aos Estados, ao Distrito federal e aos Municípios para o desenvolvimento de seus sistemas de ensino e atendimento prioritário à escolaridade obrigatória. (Idem, p. 339)

Pelo artigo, os municípios também teriam seus sistemas de ensino, para o que deveriam contar com o papel supletivo da União, agora materializado tanto na assistência técnica quanto financeira, tendo como referência 0 atendimento prioritário à escolaridade obrigatória.

O parágrafo $2^{0}$ do mesmo artigo teve sua redação alterada no Substitutivo 2, na perspectiva de ampliação das competências dos municípios, como formulado no anteprojeto final da Subcomissão pelo relator João Calmon. Vale observar que no mesmo anteprojeto o planejamento da relação entre os entes federados para articulação e desenvolvimento dos níveis de ensino com prioridade para o Ensino Fundamental, erradicação do analfabetismo e melhoria da qualidade de ensino deveria estar consubstanciado no Plano Nacional de Educação para onde se deslocariam também as disputas quanto às competências.

O Substitutivo I previa que: "Os municípios só passarão a atuar em outros níveis de ensino quando as necessidades do Ensino Fundamental estiverem plenamente atendidas". Esta restrição é retirada do texto, abrindo possibilidades no Substitutivo II para que o município atuasse em outros níveis de ensino: "Os municípios atuarão prioritariamente no Ensino Fundamental e pré-escolar, sem prejuízo da oferta que garanta o prosseguimento dos estudos". (Idem, p. 339) 
Nesse caso, duas questões de natureza diferentes são entrelaçadas na redação: as competências dos municípios e o direito ao prosseguimento dos estudos. As formulações na Subcomissão caminharam no sentido de que o município ficasse prioritariamente responsável pelo Ensino Fundamental, "sem prejuízo de oferta que garanta o prosseguimento dos estudos." (ANC, 1988b, p. 5657)

A tensão estava ao alcance das competências municipais, isto é, ao alcance da municipalização. Vale observar que o documento $\mathrm{H}$, assinado pelo presidente da Comissão VIII, Marcondes Gadelha, no parágrafo $2^{\circ}$ do artigo $7^{\circ}$ definia que competiria aos estados e municípios, por meio de lei complementar estadual, organizar e oferecer o ensino básico e médio.

Tratava-se de deslocar a definição de competências para a esfera estadual, permitindo que as determinações legais fossem estabelecidas entre cada Estado e seus municípios. Em função das desigualdades entre os municípios e os estados, havia falta de vagas, de recursos, de infraestrutura, de educadores habilitados, de equipes pedagógicas e técnicas. Neste contexto e sem definições nacionais estabelecidas seria mais fácil à rede privada disputar recursos públicos para oferecer vagas em muitos lugares e regiões do País.

Claro está que os liberais dos partidos de centro-direita sabiam que quanto menos específicas fossem as competências municipais maiores seriam as chances, sobretudo por meio de bolsas de estudo, de que as vagas oferecidas pela iniciativa privada fossem preenchidas de modo a suprir as deficiências de atendimento do Estado, prever e auferir ganhos. É certo que os defensores da livre iniciativa na educação viam no Estado a oportunidade de riscos menores. A livre iniciativa, como se verificou em diferentes momentos e situações da história republicana, tinha como interesse e projeto um capitalismo sem riscos.

Inversamente, a garantia do direito aos estudos em escolas públicas demandava precisão e articulação das competências dos entes federados. De novo, os setores privatistas se mostravam presentes, pois o município, não podendo atender aos níveis ulteriores ao Ensino Fundamental teria que se valer da oferta de bolsas de estudo. 
Não é outra a razão pela qual no referido documento $H$, elaborado pelo presidente da Comissão VIII e um grupo de parlamentares ligados à chamada centro-direita, representando interesses dos setores privatistas, não há qualquer referência à atuação prioritária do município em relação ao Ensino Fundamental, exatamente quando vinha se consolidando no processo da Constituinte a visão de que o Ensino Fundamental deveria ser público, obrigatório e gratuito.

Novamente aqui se constata o deslocamento do campo do direito e da cidadania para o das necessidades e das carências. A esse respeito, Bosi demonstrou as consequências do deslocamento de recursos públicos, por meio de bolsas de estudo, para "os ditos pobres ou dependentes".

Desaparece, de plano, a mediação universal que é figura do estudante de escola pública, cidadão igual aos colegas perante a lei.(grifo do autor) Essa mediação obtém-se, numa sociedade democrática, pelo bom uso de impostos gerais que todos os cidadãos se devem mutuamente, conforme o seu salário e as suas rendas.

Os tributos devem ser geridos publicamente por um governo representativo, o qual aplicará - também publicamente - os seus recursos em áreas consideradas prioritárias para todos os cidadãos.

Na verdade, a escola dita "gratuita", acessível a todos, baseia-se no pressuposto de que TODOS JÁ ESTÃO PAGANDO, PROPORCIONALMENTE, VIA ESTADO, PARA O BEM DE TODOS E DE CADA UM. (Bosi, 1986, p. 66).

Bosi colocou como tarefa do Estado, por meio da justiça tributária e social, a superação das iniquidades produzidas pela exploração do trabalho.

Cada cidadão deve merecer a redistribuição constante e sistemática do bem público, principalmente em setores vitais que empenham a pessoa e a sociedade por um tempo longo, como é o ensino de $2^{\circ} \mathrm{e}$ $3^{\circ}$ graus. O mesmo raciocínio vale para os órgãos responsáveis pela saúde pública. [...]

A quem não tem, ao "menos favorecido", para usar de um velho eufemismo, não é o caso de conceder, nem de emprestar, mas, sim, de restituir, sob a forma de bens materiais e culturais, o que o pobre paga com o seu trabalho, no dia-a-dia, gerando a renda nacional. $\mathrm{O}$ Estado democrático, no regime capitalista, não pode fazer menos do que corrigir o mercado e compensar a erosão que a mais-valia produz no salário e na vida do trabalhador. (Ibidem)

A natureza das formulações sobre fontes de financiamento e destinação do fundo público, como contraface do debate sobre as responsabilidades do Estado, se 
expressa no artigo 238, ao tratar da vinculação de recursos. A vinculação retorna ao texto do Substitutivo II:

A União aplicará, anualmente, nunca menos de dezoito e os Estados, o Distrito Federal e os Municípios vinte e cinco por cento, no mínimo, da receita resultante de impostos, inclusive a proveniente de transferência, na manutenção e desenvolvimento do ensino. (Anexo $\mathrm{N}$, p.339)

O texto do Substitutivo I indicava que o "Poder Público assegurará recursos financeiros para a manutenção e desenvolvimento dos seus sistemas de ensino, tendo como base padrões mínimos de qualidade e custos, definidos nos termos da lei". (Idem, p.339)

O parágrafo 1을 do artigo 238 estabelecia que: o produto da arrecadação de impostos transferido pela União aos Estados, Distrito Federal e Municípios ou pelos Estados aos respectivos Municípios, é considerado, para efeito do cálculo previsto no "capuf", receita do governo a que é entregue. (Idem, p. 340)

A redação do artigo passou a ser a seguinte:

A parcela da arrecadação de impostos transferida pela União aos Estados, Distrito Federal e Municípios, ou pelos Estados aos respectivos Municípios, não é considerada, para efeito do cálculo previsto no "caput", receita do governo que a transferir. ${ }^{63}$ (Idem, p. 340 , grifo nosso)

O parágrafo $2^{0}$ completou as definições do artigo 238, não previsto no Substitutivo 1, e o parágrafo 3ํ, se manteve basicamente, com a mesma redação:

Para efeito do cumprimento do disposto no "caput" deste artigo, serão considerados os sistemas de ensino federal, estaduais e municipais

A repartição dos recursos públicos assegurará prioridade ao atendimento das necessidades do ensino obrigatório, nos termos do Plano Nacional de Educação. (Idem, p.340)

As definições sobre financiamento abarcariam os artigos relativos à contribuição do salário-educação, cuja destinação envolveu um dos pontos de maior

\footnotetext{
${ }^{63}$ Neste caso a vinculação incidiria sobre a receita resultante de impostos não se confundindo com a totalidade dos recursos orçamentários, nem tributários (o imposto é uma espécie de tributo). As contribuições sociais, como o salário-educação, não integram a base de cálculo. A vinculação referese à receita líquida. Portanto, não se consideraria para o cálculo, de acordo com a proposição, a parcela de arrecadação transferida pela União aos demais entes da Federação e dos Estados aos seus Municípios. (Sena, 2002)
} 
disputa no que tange à destinação do Fundo Público. No Substitutivo I ficou estabelecido que: "As empresas comerciais, industriais e agrícolas contribuirão com o salário-educação, na forma da lei." (Anexo N, p. 340)

Por sua vez, o artigo 242 do Substitutivo estabelecia que: "o ensino público fundamental terá como fonte adicional de financiamento a contribuição social do salário-educação, a ser recolhida pelas empresas na forma da lei”. (Idem, p.340).

A vinculação do salário-educação ao atendimento obrigatório, público e gratuito do Ensino Fundamental, constituía-se em limitação a qualquer tentativa de tornar essa contribuição social disponível para outros níveis de ensino por meio da oferta de bolsas de estudo em instituições privadas. Contudo, a vinculação dessa contribuição social ao Ensino Fundamental obrigatório e público, restringia as possibilidades de utilização desse recurso pelas entidades privadas posto que era preciso assegurar condições de acesso e permanência a milhões de crianças entre 7 a 14 anos.

Em relação à destinação dos fundos públicos, o Substitutivo I precisava que:

Os recursos públicos serão destinados às escolas públicas, podendo, nas condições da lei e em casos excepcionais ser dirigidos a escolas confessionais, filantrópicas ou comunitárias desde que:

I provem finalidades não lucrativas e reapliquem excedentes financeiros em educação;

Il prevejam a destinação de seu patrimônio a outra escola comunitária, filantrópica ou confessional ou ao Poder Público, no caso de encerramento de suas atividades. (Idem, p. 341)

A mudança fundamental foi no caput, com a retirada da referência a "excepcionalidade". Também ficava definida pela Comissão de Sistematização, a possibilidade de transferência de recursos públicos para as escolas públicas, como se constata: "Os recursos públicos serão destinados às escolas públicas, podendo ser dirigidos a escolas comunitárias, confessionais ou filantrópicas definidas em lei, que:" (Idem, p. 341)

Por fim, o Substitutivo II estabeleceu que seria o Conselho Federal de Educação que definiria o Plano Nacional de Educação, restringindo o alcance da participação dos cidadãos, uma vez que o Substitutivo I determinava que o PNE seria definido em lei. Este Substitutivo I foi votado em sessão pública na qual sete emendas foram apresentadas ao texto: três em relação aos recursos públicos; duas 
sobre a universidade; uma sobre os Centros Integrados de Ensino Público (CIEP); e uma sobre a elaboração do Plano Nacional de Educação pelo Conselho Federal de Educação (CFE). (Pinheiro, 2005)

Em relação à destinação do Fundo Público, Florestan Fernandes (PT-SP) apresentou uma emenda, recolocando a proposta de verbas públicas para a escola pública. Na condição de relatora auxiliar, Sandra Cavalcanti (PFL-RJ), ao se manifestar de forma contrária, mesclou argumentos discutidos em outras fases, pretendendo redefinir o sentido do que é público. Esvaziando-se, uma vez mais na ideia de direito a educação foi definida como prestação de serviço a ser realizado tanto por entidades oficiais da rede estadual como por entidades sem fins lucrativos. Ao fazê-lo a deputada pretendia reforçar a aliança com os setores da Igreja, agora discorrendo mais sobre as condições de recebimento de recursos, do que sobre a natureza das instituições e a liberdade das famílias.

Outras emendas, contudo, reporiam a discussão da transferência de recursos públicos para instituições privadas. Mozarildo Cavalcanti (PFL-RR) pretendia que a destinação das verbas públicas não ficasse restrita às escolas "filantrópicas, comunitárias e confessionais". Victor Faccione (PDS- RS), por meio de sua emenda pretendia que as bolsas de estudo não fossem financiadas apenas pelo salárioeducação, isto é, defendeu que os recursos fossem destinados diretamente às entidades de ensino privadas ou para bolsas de estudos nestas instituições. Todas as emendas apresentadas sobre destinação dos fundos públicos foram rejeitadas.

Emenda apreciada e, desta feita, aprovada foi a que determinava que o Plano Nacional de Educação fosse admitido por lei e não, como previsto no Substitutivo II, pelo Conselho Federal de Educação.

Observe-se que Cavalcanti e Faccione não agradaram os parlamentares de centro e direita que não atuaram apenas em função das orientações das lideranças de suas bancadas e partidos. O posicionamento dos parlamentares expressou, em maior ou menor grau, os interesses da base social que representavam o que permitiu acordos e articulações suprapartidários que deram origem ao Bloco autodenominado Centrão. Limitados pelo regimento para alterar os projetos de Constituição produzidos no âmbito da Comissão de Sistematização, estes setores, apoiados no documento intitulado "Democracia e desenvolvimento", que teria 
contado com o apoio do Palácio do Planalto, (Rocha, 2013 p. 82) tornaram a mudança regimental o foco do conflito.

Seria simplista não perceber que a crise se abriu com a conformação do Centrão expressando as contradições da Aliança Democrática, na medida em que seus principais partidos tinham também as maiores bancadas da ANC e os que tinham mais representantes no Centrão (Munhoz, 2011, p. 351).

Florestan Fernandes analisou esse período como expressão de uma crise de poder, na qual "setores dirigentes das classes burguesas" arruinaram seus partidos e a autonomia relativa dos políticos profissionais. O Planalto teria se aproveitado dessa crise para sobrepor-se à ANC e assegurar uma Constituição conservadora. Assim se posicionou:

O Governo encontrou escancaradas todas as portas que poderiam facilitar pressões ilegítimas, influências espúrias e, até mesmo, a corrupção desenfreada. Aproveitou-as uma a uma, como se estivesse envolvido em um "jogo de guerra", cujo objetivo final fosse a derrota da ANC e a consagração da "vontade constituinte" da Presidência. O primeiro movimento consistiu em um ataque frontal, através da indicação de um líder do Governo na Câmara dos Deputados, Carlos Sant'Anna, um golpe ultrajante que não foi repelido. O movimento seguinte voltou-se para arregimentação de tropas próprias, compostas por constituintes de "centro" e "democráticos". O Correio Brasiliense noticiou em primeira mão que havia dez mil cargos colocados à disposição desses constituintes. A notícia causou perplexidade, e o escândalo foi denunciado no plenário da ANC. (Fernandes, 1989, p.106)

Com efeito, Florestan colocava em questão a soberania da Constituinte e sua legitimidade, em particular, junto aos setores populares. Dizia ainda:

Os partidos da ordem conviveram do melhor modo possível com a intromissão, e o governo Sarney ganhou a batalha, plantando dentro da ANC o seu "grupo de centro" ou a "turma do DO", que conferiu ao Presidente e aos seus ministros que o desejaram a liberdade de manipular todos os assuntos de importância vital para o Executivo, seus acordos políticos, suas alianças com interesses privados e com instituições como a Igreja Católica, ou para adaptar dispositivos constitucionais a negociatas de caráter pessoal. Muitas escaramuças e conflitos execráveis entre os constituintes tiveram suas origens nessa trama de envolvimento ou de repúdio à podridão do regime. Os que resistiram pertencessem ao PMDB, ao PFL, ao PTB, ao PDS ou à esquerda foram estigmatizados como "a minoria radical", que recorria à baderna para impor teses constitucionais "exóticas e "alheias ao temperamento do Povo brasileiro [...]" (Ibidem) 
Duas dimensões situam a constituição e a ação do Centrão nas palavras de Florestan, a ação do Estado visando a preservar interesses econômicos de diferentes setores da burguesia brasileira, mas também dos interesses específicos e particularistas. A outra dimensão se refere ao discurso ideológico que não cessava de buscar abrigar tais interesses sob a noção de um povo homogêneo que partilhasse de uma identidade comum. A perspectiva autoritária do discurso da Aliança Democrática e de seus representantes no Congresso Nacional se completava com as tentativas recorrentes, como aponta Florestan, de desqualificar e deslegitimar as experiências de organização de diferentes setores da sociedade civil, de desqualificar as propostas e de estigmatizar os sujeitos, mesmo quando integravam a base de sustentação do governo.

A violência e a virulência de algumas das manifestações públicas e das manobras realizadas pelos constituintes que integravam o Centrão denotam que, malgrado todas as ações de cooptação levadas a efeito pelo governo Sarney e o ambiente de depreciação da formulação política e programática que se instalou, decorreram da dialética construída pela natureza da presença de movimentos e entidades da sociedade civil, notadamente, dos movimentos populares. No caso da educação foi se tornando visível, ao longo do processo constituinte, que a estrutura dos vários anteprojetos se referia aos direitos e concepções formulados no âmbito da Subcomissão de Educação, Cultura e Esportes e da Comissão VIII. (Munhoz, 2011)

Neste contexto, onde uma vez mais se fez mostrar o clientelismo e o patrimonialismo que marcaram a cultura política do País, as datas estipuladas para a conclusão dos trabalhos da Comissão de Sistematização não foram cumpridas. Assim de 17 de setembro a votação foi adiada para 28 de outubro de 1987 e depois para 30 de outubro de 1987. A emenda do Centrão foi apresentada em 11 de novembro de 1987. O texto estabelecia que ficava facultada à maioria absoluta dos membros da Assembleia Nacional Constituinte a apresentação de substitutivos a títulos, capítulos, seções e subseções a dispositivos do Projeto de Constituição, sendo que caberia ao relator da Comissão de Sistematização, no prazo máximo de sete dias, emitir parecer conclusivo pela aprovação ou rejeição da matéria, não podendo subemendá-la ou concluir por substitutivo. (ANC, 1988c) 
Nova votação para aprovação do Substitutivo foi prevista para 17 de novembro, ocorrendo no dia seguinte, quando negociada a apresentação de emendas para todos os constituintes e não só para os membros da Comissão. Além disso, foi elaborado em 24 de novembro de 1987, o projeto que seria analisado no transcurso do $1^{\circ}$ turno.

O Regimento foi aprovado em 3 de dezembro de 1987, com 290 votos a favor, 16 contrários e 3 abstenções, porque os partidos de esquerda e parte do PMDB se retiraram do Plenário. A Comissão de Sistematização deixava de existir e seria substituída pela figura individual do relator geral. A redação final do Projeto deveria acontecer em uma comissão específica.

De acordo com o novo regimento, o "Centrão" pôde apresentar um projeto alternativo de Constituição que pretendia substituir o Projeto $A^{64}$, por meio da emenda 2044 de 13 de janeiro de 1988, contando com 288 assinaturas. Nesta mesma ocasião foram apresentadas ainda 2045 emendas. Paralelamente, começou a se fortalecer o Colégio de Líderes dos partidos, de modo a assegurar uma agenda do processo e a costura de acordos que permitissem governabilidade no Plenário. (Figueiredo; Limongi, 1999)

Florestan considerou que não existiam contradições entre o projeto constitucional do "Centrão" e o projeto de constituição $(A)$ da Comissão de Sistematização: "Longe de ser um Frankenstein, o projeto do 'Centrão' refina o Estado patrimonialista". E continuou:

É a Constituição necessária nos trópicos, nas fronteiras extremas da civilização e no ápice da barbárie: um Estado de opressão dos de baixo, de monopolização do poder político estatal pelos de cima e de acumulação capitalista originária, permanente, para a burguesia "nacional" e "estrangeira".

As conseqüências são claras. Esse tipo de constituição, por si mesma, entra em conflito com a nação como um todo e remove da carta constitucional a essência da função do Parlamento na vida moderna. Ele não permitirá canalizar para o Parlamento as lutas de classes, porque deixa de ser um canal institucional de solução dos conflitos econômicos, sociais, culturais e políticos. A luta de classe é expulsa para o seio da sociedade civil onde ela crepita de modo crescentemente mais denso e violento [...] (Fernandes, 2014, 203-4)

\footnotetext{
${ }^{64}$ As diferenças entre o Substitutivo II, de 18 set. 1987, e o Projeto (A), de 24 nov. 1987, não foram significativas razão pela qual não realizaremos aqui a comparação entre eles.
} 
Observe-se, entretanto que se as tentativas de submeter os direitos públicos aos interesses privados, no caso da Educação, seguiam sendo um dos principais vetores de ação dos parlamentares agrupados no Centrão é certo que o faziam no contexto de formulações inéditas na história das constituições brasileiras, em relação ao direito à educação e às responsabilidades do Estado em face de tais direitos. O debate no Plenário da Constituinte foi marcado pelo dissenso e pelo conflito entre o projeto da Comissão de Sistematização e a Emenda 2044 do Centrão. Como os deputados deste agrupamento tinham maioria, se estabeleceu um quadro de negociações entre as lideranças dos partidos, resultando em uma emenda conjunta de fusão que veio a constituir o Projeto $B^{65}$. A votação ocorrida em 19 de maio de 1988 expressou o resultado da negociação: quatrocentos e quarenta e três votos a favor da emenda de fusão, dois votos contra e três abstenções. (Farenzena, 2001, p.112)

Examinando o Projeto (B) pode-se constatar as principais inflexões realizadas no texto a partir do acordo referido. $O$ direito à educação, uma vez mais apareceria no artigo 210 do Substitutivo (B), como dever do Estado e da Família. Quanto à redação se manteve nos textos do Projeto C (15 set.1988):

A educação, direito de todos e dever do Estado e da família, será promovida e incentivada com a colaboração da sociedade, visando ao pleno desenvolvimento da pessoa, seu preparo para o exercício da cidadania e sua qualificação para o trabalho (Anexo N, p. 334)

Foram retirados do texto "o repúdio a todas as formas de preconceito" e passou a integrá-lo o preparo para a cidadania e a qualificação para o trabalho. A educação era de novo definida como direito de todos. O inciso I do artigo 210 do Projeto (B) estabeleceria que em vez de "democratização" deveria haver "igualdade de condições" para o acesso e permanência na escola e assim o texto se manteria até a versão final. (Idem, p. 335)

Uma modificação significativa foi introduzida no inciso IV do artigo 211 do Projeto (B). A gratuidade do ensino público, definida como um dos princípios da educação deveria ocorrer em estabelecimentos oficiais. Isto significa que prevalecia

65 O estudo de Munhoz (2011, p. 367-8) demonstra que embora o PMDB tivesse participação expressiva em números absolutos no Centrão menos da metade de sua bancada votou com o bloco. Dessa maneira o PDS, PFL e PTB teriam tido maior participação nas votações. A autora conclui que foram os partidos, com maior ligação com os governos militares que sustentaram as votações do Centrão em Plenário. 
uma definição política sobre a educação pública e gratuita como aquela oferecida diretamente pelo Estado em instituições por ele criadas, não obstante, as definições de progressividade e metas de atendimento fossem matérias a serem tratadas no âmbito da Lei de Diretrizes e Bases da Educação e do Plano Nacional de Educação.

Foi em relação à gestão democrática prevista no inciso IX do artigo 211 (Projeto B) que se extraiu a referência à participação de representantes da comunidade, alunos, funcionários e docentes, remetendo à lei a regulamentação. Igualmente nesse caso, essa seria a versão final. (Anexo N, p. 335)

Da mesma forma vale indicar a precisão em relação ao parágrafo $2^{\circ}$ do artigo 212 do Projeto (B), no qual o não oferecimento do ensino obrigatório pelo Poder Público em vez do Estado importaria a responsabilidade da autoridade competente (no singular), e não das autoridades competentes, tornando ainda mais precisa a responsabilidade de prefeitos e governadores. Esta redação não seria alterada até o final dos trabalhos (Idem, p. 337).

Em relação ao caput do artigo 214 (projeto B) ficou indicado que a "União, os Estados, o Distrito Federal e os Municípios deveriam organizar, em regime de colaboração, os seus sistemas de ensino". O plural tornava inequívoca a possibilidade de que cada ente federado tivesse seu sistema de ensino, cuja existência não integraria um mesmo sistema, mas seria levada a efeito por meio do que ficou definido como regime de colaboração. (Idem, p. 339).

Do mesmo modo, o parágrafo $2^{\circ}$ do mesmo artigo foi alterado, retirando-se do texto a referência explícita que permitia aos municípios atuarem em outros níveis de ensino, sendo apenas indicada a sua competência específica, a saber: "Os Municípios atuarão prioritariamente no ensino fundamental e pré-escolar". (Idem, p. 339). A redação permaneceria a mesma até o final do processo.

Quanto ao salário-educação, o parágrafo $5^{\circ}$ do art. 215 do Projeto B (Anexo $\mathrm{N}$, p. 340) trouxe de volta ao texto a possibilidade de dedução, pelas empresas, da aplicação realizada com o Ensino Fundamental relativo aos seus empregados e dependentes. A isso se somaria, do ponto de vista da destinação dos recursos, uma precisão importante presente no parágrafo $2^{\circ}$ do artigo 215 do Projeto (B): "Para efeito do cumprimento do disposto no "caput" deste artigo, serão considerados os 
sistemas de ensino federal, estadual e municipal e os recursos aplicados na forma do art. 216". (Idem, p. 340)

O caput do artigo se referia à vinculação de recursos nos âmbitos federal, estadual e municipal e o texto acima citado reforçava a ideia da existência de um sistema no âmbito de cada um dos entes federados. A redação, também nesse caso, se manteve a mesma até o final. A mudança fundamental em relação à destinação dos recursos públicos aconteceria a partir da introdução do parágrafo $1^{\text {o }}$ do artigo 216 do Projeto (B). Dizia o caput: "Os recursos públicos serão destinados às escolas públicas, podendo ser dirigidos a escolas comunitárias, confessionais ou filantrópicas, definidas em lei que:" (Idem, p. 341)

O parágrafo trouxe de volta a possibilidade da concessão de bolsas de estudo:

Os recursos de que trata este artigo poderão ser destinados a bolsas de estudo para o ensino fundamental e médio, na forma da lei, para os que demonstrarem insuficiência de recursos, quando houver falta de vagas e cursos regulares da rede pública na localidade da residência do educando, ficando o poder público obrigado a investir prioritariamente na expansão de sua rede na localidade. (Idem, p. 341)

Malgrado a possibilidade de utilização dos fundos públicos para a concessão de bolsas de estudos para o ensino fundamental e médio representasse uma vitória dos setores privatistas, ela estava mediada por uma determinação importante que pretendia estabelecer temporalidade definida para esta destinação. O Poder Público deveria expandir rede própria em cada um dos lugares. Esta limitação foi reforçada pela precisão realizada no inciso IV do artigo 211 que definia como princípio da educação nacional a gratuidade do ensino público em estabelecimentos oficiais não havendo, portanto, indistinção entre as escolas públicas e privadas, no que se refere à oferta de vagas para o Ensino Fundamental obrigatório e demais níveis de ensino, como pretendiam os parlamentares comprometidos com os interesses das escolas privadas e com o ideário liberal.

As definições em relação às Universidades, no Projeto (B), foram estabelecidas como princípios nos incisos X e XI do artigo 211:

Autonomia didático-científica, administrativa e de gestão financeira e patrimonial das universidades; [...] 
Indissociabilidade entre ensino, pesquisa e extensão e garantia de padrão de qualidade, na educação superior. (Idem, p.336)

A referência ao padrão de qualidade na Educação Superior seria retirada do texto no Projeto (C) apresentado no Plenário em 15 de setembro de 1988, no final do $2^{\circ}$ turno de votação. Ainda no Projeto (C), o inciso VII do artigo 206 faria referência a indissociabilidade entre ensino, pesquisa e extensão nas universidades e não mais na educação superior. O Projeto $D$ de 21 de setembro elaborado pela Comissão de Redação Final trataria a Universidade em artigo específico com o mesmo conteúdo. A redação final do artigo 207 do texto promulgado foi a seguinte:

As universidades gozam de autonomia didático-científica, administrativa e de gestão financeira e patrimonial, e obedecerão ao princípio de indissociabilidade entre ensino, pesquisa e extensão. (Anexo N, p.336)

No Projeto (B) houve aperfeiçoamento da redação do artigo 217 sobre o Plano Nacional de Educação que se manteve no texto da redação final:

A lei estabelecerá o plano nacional de educação, de duração plurianual, visando à articulação e ao desenvolvimento do ensino em seus diversos níveis e à integração das ações do Poder Público que conduzam à:

$[\ldots]$

I - erradicação do analfabetismo; [...]

II - universalização do atendimento escolar; [...]

III - melhoria da qualidade de ensino; [...]

IV - formação para o trabalho; [...]

$\mathrm{V}$ - promoção humanística, científica e tecnológica do País. [...] (Anexo N, p. 341-2)

Vale destacar as formulações relativas aos artigos do Ato das Disposições Constitucionais Transitórias. A redação estabelecida no caput do artigo 67 do Projeto (B) se manteve até a redação final:

Nos dez primeiros anos da promulgação da Constituição, o poder público desenvolverá esforços, com a mobilização de todos os setores organizados da sociedade e com a aplicação de, pelo menos, cinqüenta, por cento dos recursos a que se refere o art. 212 da Constituição, para eliminar o analfabetismo e universalizar 0 ensino fundamental. (Anexo N, p.421) 
O parágrafo único do artigo 67 das Disposições Constitucionais Transitórias do Projeto $B$, que se referiu à expansão das universidades públicas, permaneceu com a mesma redação na versão promulgada em 05 de outubro de 1988:

Em igual prazo, as universidades públicas, descentralizarão suas atividades, de modo a estender suas unidades de ensino superior às cidades de maior densidade populacional. (Idem, p.421)

Por fim o artigo 68, previsto no Projeto B, estabeleceu que:

As entidades educacionais a que se refere o art.216, bem como as fundações de ensino e pesquisa cuja criação tenha sido autorizada por lei, que preencham os requisitos dos incisos I e II do referidos artigo e que, nos últimos três anos, tenham recebido recursos públicos, poderão continuar a recebê-los, salvo disposição legal em contrário. (Idem, p. 421)

O Projeto (B) de 05 de maio de1988 recebeu 1.844 emendas supressivas, para sanar omissões, erros ou contradições e, ainda, para precisões de redação e linguagem. (Brusco; Ribeiro apud Farenzena, 2011).

A votação de segundo turno que compreendeu a apreciação das emendas ao Projeto B, ocorreu entre 25 de julho e $1^{\circ}$ de setembro de 1988 . Conforme Pinheiro, a votação realizada em 30 de agosto de 1987 apreciou sete emendas supressivas, sendo que cinco foram retiradas antes do processo de votação, entre as quais, aquelas relativas à supressão da obrigatoriedade de oferta do ensino religioso na escola pública.

Por sua vez, as duas emendas mantidas se referiam à supressão do artigo que garantia transferência de recursos para as escolas comunitárias, de autoria de Florestan Fernandes (PT-SP), e a segunda, de autoria do deputado Victor Faccioni (PDS-RS), estendia o mecanismo de distribuição de bolsas de estudo também para o Ensino Superior.

Quanto aos conflitos em torno dos destinos dos fundos públicos chegaram até a fase final da Constituinte, o que tornou evidente que a maioria numérica exercida pelo Centrão com o apoio do governo da Aliança Democrática, não foi suficiente para eliminar do espaço público as posições e proposições construídas desde o início dos trabalhos da Constituinte. Os sujeitos tornaram suas opiniões públicas, 
portanto, comunicáveis e visíveis. E o conflito ocupou o espaço público. Fruto da negociação do Projeto $B$, as duas emendas foram rejeitadas ${ }^{66}$, mantendo-se o texto.

O Projeto B com as respectivas emendas deu origem ao Projeto (C), aprovado ao final do $2^{\circ}$ turno, em 15 de setembro de 1988. A partir de então, o texto foi para a Comissão de Redação $^{67}$ onde foram apreciadas proposições exclusivamente dessa natureza, para então ser promulgada no dia 05 de outubro de 1988.

Em comparação às constituições anteriores, os princípios consagrados no artigo 206 e as determinações referentes ao artigo 208 da Constituição compõem um marco em relação à garantia do direito à educação. Os princípios se articulam em torno de três questões indissociáveis: a primeira se refere à liberdade no processo educacional, definida pela garantia do pluralismo de ideias e concepções pedagógicas, pela liberdade de pesquisar, divulgar o pensamento, a arte e o saber, de aprender, de ensinar e a gestão democrática do ensino; a segunda diz respeito ao papel do Estado na garantia da educação, expresso na gratuidade do ensino, não obstante esteja assegurada a coexistência de instituições públicas e privadas de ensino, e a igualdade de condições para o acesso e permanência na escola; e a terceira refere-se à qualidade da educação, definindo a valorização dos profissionais, por meio do estabelecimento em lei de piso salarial profissional, plano de carreira e concurso público de provas e títulos e, por outro lado, a garantia de um padrão de qualidade, o que passa a ser parte do direito à educação.

Note-se que no âmbito do artigo 208 o direito ao ensino fundamental foi estabelecido a partir de dupla obrigatoriedade "de um lado, a do Estado de garantir tal direito e, de outro, ao dever do pai ou responsável de provê-la, uma vez que passa a não fazer parte do seu arbítrio a opção de levar ou não o filho à escola" (Oliveira, 1995, p.10). Garantiu-se também programas suplementares de material didático-escolar, transporte, alimentação e assistência à saúde para o educando do Ensino Fundamental. Além disso, assegurou-se que os jovens e adultos também gozassem do acesso ao Ensino Fundamental, nos casos em que não o tivessem

\footnotetext{
${ }^{66}$ A emenda do deputado Florestan Fernandes foi rejeitada, teve 340 votos contrários, 88 favoráveis e 5 abstenções. A emenda do deputado Victor Faccioni, também rejeitada teve 230 votos contrários, 192 favoráveis e 3 abstenções.

${ }^{67}$ A Comissão de Redação iniciou seus trabalhos em 20 de abril e encerrou em 20 de setembro 1988. Foi presidida por Ulysses Guimarães (PMDB-SP) e teve como relator Bernardo Cabral (PMDB-AM)
} 
cursado em idade própria, definição que permitia o estabelecimento de uma política para a Educação de Jovens e Adultos como possibilidade de superação de campanhas e ações pontuais fragmentadas e fragmentárias. Da mesma forma, nesse caso a definição não foi encontrada em outras constituições.

Aliás ficou definido que os estados teriam responsabilidade na garantia de todos os níveis e modalidades de ensino aos portadores de deficiências, atendendo de preferência alunos de creche e pré-escola com idade de zero a seis anos de idade, da rede regular de ensino, estendendo a obrigatoriedade ao Ensino Médio. Registre-se também a garantia de curso noturno regular adequado às condições do educando.

A responsabilização da autoridade competente, quando não oferecido o ensino obrigatório pelo Poder Público, reveste-se de caráter particularmente importante. Como afirmou Cury et. al. (2005, p. 20) "o direito público subjetivo auxilia e traz um instrumento jurídico institucional capaz de transformar este direito num caminho real de efetivação de uma democracia educacional".

Esse conjunto de definições reconfigurou o campo do direito à educação no Brasil e a perspectiva de destinação dos fundos públicos. Não obstante a vinculação de recursos - União $18 \%$ e estados e municípios $25 \%$ - da receita de impostos compreendida a proveniente de transferências pudesse ser disputada tanto pelas escolas comunitárias, filantrópicas ou confessionais, quanto pelas instituições privadas, por meio da destinação de recursos às bolsas de estudo, no âmbito do ensino fundamental e médio. $O$ fato é que teria que fazê-lo no contexto de políticas educacionais que passariam a ter como referência as determinações constitucionais.

No contexto da transição conservadora, a aparição de sujeitos sociais que pronunciaram seus direitos e formularam políticas diante do Estado Nacional e dos representantes da sociedade na Assembleia Constituinte tornariam a disputa pelos fundos públicos uma questão nacional da República e da democracia. 


\title{
CONSIDERAÇÕES FINAIS
}

A profunda crise do Estado brasileiro, que esteve na origem da pretendida abertura lenta e gradual, levada a efeito pelo governo do Gal Ernesto Geisel e pelas forças sociais que o sustentavam, explica o caráter que se procurou imprimir ao processo Constituinte instalado no Brasil em 1987. A saída dos militares do poder deveria ser concretizada a partir de uma conciliação que se sobrepusesse as Diretas-Já reivindicadas por milhares de pessoas nas ruas. Por isso os setores conservadores apoiaram a eleição de um civil pelo Colégio Eleitoral inaugurando a Nova República sustentada pela aliança entre o Partido Liberal (PL) e o Partido do Movimento Democrático Brasileiro (PMDB) a chamada Aliança Democrática.

\begin{abstract}
Aliaram-se os chefes militares "civilizados", o PMDB através de suas cúpulas dirigentes e os "democratas" recém-saídos do ventre do regime em decomposição. Isso significa que a oscilação foi detida por uma nova conspiração, que se crismou como um ato de conciliação política. [...] Convertido em partido da ordem, o PMDB deu guarida à Aliança Democrática, pela qual os chefes militares e os notáveis da ditadura iriam cobrar, em conúbio com a maioria conservadora da cúpula do PMDB e do Parlamento a continuidade da ordem ilegal forjada pela República institucional. (Fernandes, 1988, p.15)
\end{abstract}

Tal qual Florestan Fernandes, para os conservadores tratava-se de remover o chamado "entulho autoritário" em vez de superar uma ordem ilegal. Tratava-se de "uma colossal mistificação, pela qual a ordem ilegal não é expelida da cena histórica e condiciona, ao contrário, o processo de reconstrução da sociedade civil e do Estado" (Ibidem) De outro lado estavam aqueles que defendiam uma Assembléia Constituinte exclusiva e soberana.

Com efeito, como indicou Florestan, um Congresso Constituinte poderia ser limitado pela instância judiciária e ainda, pelos próprios militares. Já a Constituinte exclusiva e soberana prefigurava uma solução para a crise do Estado e do próprio capitalismo brasileiro que dependeria do peso e da participação dos oprimidos, dos trabalhadores na sociedade civil para exercer o controle ativo sobre o funcionamento do Estado. 
envolve uma ruptura com a ordem existente no plano mais sensível e popular do sistema do poder; o Parlamento considerado como poder constituinte. Como poder emanado do Povo, neste momento, a Assembléia Nacional Constituinte derroga a ordem ilegal vigente e a ilegitimidade da Nova República, e afirma a própria faculdade de instituir normas constitucionais civilizadas para o funcionamento da sociedade civil e normas constitucionais democráticas para a organização do Estado. O presente e o futuro pertencem à Nação, não à minoria no poder. A ruptura com o atual estado de coisas representa a conquista de novas vias de evolução histórica e, sob pressão popular, a elaboração de uma Constituição que defina os requisitos mínimos da extinção simultânea do subcapitalismo e do capitalismo perverso ou selvagem. (Ibidem, p. 16)

A explicitação da natureza da transição e dos dilemas constitucionais conduziam o pensamento e a prática do intelectual e deputado constituinte Florestan Fernandes (PT-SP) para o compromisso de desvelar as intenções políticas que sustentavam a proposta de um parlamento constituinte e, nesse processo, contribuir para inserção de um número expressivo de trabalhadores na vida política de sorte a interferirem nos rumos da vida social e nas práticas do Estado.

Menos otimista sobre tal possibilidade se mostrou Raymundo Faoro. Entendendo que a instalação do Congresso Constituinte representava uma traição à construção de uma verdadeira democracia no País, explicitava que a chave do processo de abertura era dada pelo presidente Geisel que apresentava a abertura, e o fim do Al5, como necessidade do desenvolvimento econômico, político e social. Tal dialética comportava o reconhecimento por parte do presidente e dos militares da validade da tomado do poder, entendia que os interesses capitalistas exigiam uma nova fase de desenvolvimento no País. Um consenso construído a partir de uma conciliação oligárquica, pelo alto, a partir da coerção, inerente ao controle ideológico, poderia dar um novo impulso ao desenvolvimento brasileiro. O PMDB estaria no centro do processo como um partido que teria feito a "transição interna, nas suas fileiras, 'para fazer a transação externa fora das [suas] fileiras'”. (Faoro, 2008, p. 21-33)

Em memorável entrevista, concedida em dezembro de 1996, afirmou:

No momento em que se fez a Constituinte "dentro" do Congresso, já era o Estado Novo do PMDB que estava operando, estava trabalhando. Para que a Constituinte saia desse projeto é uma dificuldade imensa, em primeiro lugar porque o PMDB junto com o PFL é hegemônico. E a 
Constituinte foi entregue não aos deputados e senadores: o sentido do voto popular não foi votar nem em senador nem em deputado, foi em governador. A Constituinte está entregue a uma coligação de governadores que vai manter o presidente enquanto o presidente for fiel a eles. ${ }^{68}$ (Ibidem, p. 70).

A referida política de conciliação impediria, na percepção de Faoro, que a pressão popular pudesse transformar o destino da Constituinte e a natureza da Constituição. Duvida o autor da possibilidade de que houvesse pressão popular sobre a Constituinte. Considerava difícil que a proposta apresentada pelo Partido dos Trabalhadores de participação popular, de transmissão pela TV dos trabalhos da Constituinte e movimentação de caravanas a Brasília.

Nas palavras do autor:

[...] para uma mobilização dessas, eles deveriam contar com os meios de comunicação de massa e esses meios não estão disponíveis para essas forças. O governador é uma chave muito importante. Nós vimos, por exemplo, nas Diretas Já que - movimento só tomou um grande impulso quando os governadores o apoiaram, o de São Paulo e o do Rio de Janeiro. Esse espontaneísmo popular é que eu não acredito que ocorra. (Ibdem, p. 73-4)

O processo de reorganização da sociedade civil e a relação dos movimentos sociais e dos sindicatos com os partidos, particularmente com os que defendiam um programa progressista e ou socialista, contribuiu para a criação de um ambiente de participação que se expressou no regimento da Assembléia Nacional Constituinte, não obstante o empenho do governo Sarney no sentido de que houvesse um projeto prévio aos trabalhos da Constituinte. Com a derrota da proposta do governo, inaugurava-se um novo período na história das constituições na medida em que não havia um projeto inicial que orientasse as discussões.

O PMDB, em face das tradições políticas democráticas que abrigava e das contradições decorrentes do confronto entre os diferentes grupos no seu interior, aceitou que o projeto de constituição resultasse dos trabalhos do congresso constituinte. (Pinheiro, 1991, p. 84)

A criação de vinte e quatro subcomissões organizadas em torno de oito comissões, a previsão e realização de audiências públicas no âmbito das

68 "O Estado Novo do PMDB" foi o título de uma entrevista concedida por Faoro na qual associava a Nova República ao autoritarismo do Estado Novo (1937-45) e ao do regime de 1964. (Faoro, 1985) 
subcomissões e, em menor grau nas comissões, o direito de apresentação de emendas por parte de qualquer constituinte e a possibilidade de apresentação de emendas populares permitiram a realização de debates públicos, com menor ou maior amplitude, nos quais a luta de classes "se tornou visível nos dois pólos" como afirmou o constituinte Florestan Fernandes (PT-SP).

Os debates comprometeram muitos dos constituintes em função das preocupações com relação às eleições futuras de deputados e senadores.

Tais condições contribuem para a compreensão do porque uma assembléia que nasceu de uma transição "transada", como apontaram Faoro e Florestan, de composição majoritariamente conservadora, pôde abrigar inúmeras propostas de vocação progressistas, muitas das quais voltadas à realização de transformações sociais profundas, como as reformas urbana e agrária, e a concretização das revoluções democrática e nacional preteridas pelas elites no Brasil. (Fernandes, 1988, p. 61).

É indubitável que a experiência de participação política estabelecida no processo de elaboração da Constituição de 1988 a distingue das anteriores o que explica sua singularidade histórica.

Em particular no caso da Educação, tem especial relevância o fato de que além da organização e da mobilização, grande parte das entidades da sociedade civil apresentou contribuições que tomaram a forma de programas nacionais para a Educação.

Para ocupar este lugar no espaço público, a maior parte das entidades que pretendiam se tornar reconhecíveis construiu dinâmicas próprias, voltadas ao fortalecimento do debate e à elaboração de proposições. Estas dinâmicas ensejaram, por exemplo, a articulação de entidades no âmbito do Fórum Nacional da Educação na Constituinte e em Defesa do Ensino Público e Gratuito, cujas propostas se constituíram em referência para a formulação dos primeiros anteprojetos no âmbito da Subcomissão de Educação, Cultura e Esportes na medida em que o Fórum produziu estudos e proposições que se tornaram referências para o debate. A experiência do diálogo entre pesquisadores, intelectuais, sindicalistas e representantes dos novos movimentos sociais tornou possíveis a elaboração de sínteses e as formulações para uma política nacional de educação. 
Por outro lado, a participação no debate sobre educação por entidades ligadas aos indígenas, aos afrodescendentes e ao movimento de moradia, com a expressão de suas identidades sociais e culturais, desconstituiu a noção fixa de povo e, por conseguinte, de nação, que de forma exterior às experiências concretas, até então havia negado a visibilidade de tais agentes históricos e suas possibilidades de expressão social política e cultural.

A representação de uma nação indivisa começava a sofrer esgarçamentos, em função da pluralidade de expressões que romperam silêncios em diferentes espaços da Constituinte, como as comoventes manifestações realizadas pelos representantes de organizações indígenas e indigenistas.

O Brasil, sendo "constituído por cinco, seis, oito ou dez nações" experimentava pela primeira a oportunidade de elaborar uma Constituição para as diferentes nações presentes em nosso espaço territorial. (Ibidem, p.62)

É indispensável reiterar que a pluralidade de sujeitos afirmando suas identidades sociais, implicou a ampliação do espaço público e o alargamento efetivo da participação política, na medida em que o papel do cidadão pôde ir além do voto para eleger representantes. Esta experiência indicou que a relação entre representantes e representados, também nesse caso, pode ir bem além do processo eleitoral apontando a relevância dos aparatos institucionais para o desenvolvimento da democracia. Se naquela conjuntura a relação entre diferentes movimentos e entidades foi intensa em função das expectativas de garantia de direitos civis, políticos e sociais, não é menos verdade que tais práticas influenciaram os partidos e os parlamentares, deixando a marca da conquista da cidadania na trajetória social e cultural destes sujeitos.

Observe-se que as experiências democráticas no interior da Constituinte, sobretudo no âmbito das Subcomissões e o desejo de superação das práticas e da legislação da Ditadura tornou possível que um conjunto de propostas de democratização das instituições e das práticas educacionais fossem apresentadas. Tanto assim, que entre os princípios do ensino se inscreveu a gestão democrática.

A participação dos movimentos e entidades e suas proposições tiveram real importância nas formulações acerca da educação, tornando-se possível considerar que a Constituinte foi um marco no desenrolar de processos históricos 
caracterizados pelo entrelaçamento de dimensões sociais, econômicas, políticas e culturais, em particular no que se refere à educação.

A natureza e a força dessas presenças e proposições desvelam as razões e a lógica da batalha semântica, como uma das dimensões da batalha política e ideológica, travada em torno de um conjunto de noções. A mais significativa delas referiu-se aos sentidos relativos ao público e o privado. Pelo menos, três movimentos foram se tornando perceptíveis durante os trabalhos da Constituinte. $O$ primeiro pretendia opor o público e o privado ressaltando a excelência das instituições particulares, visando legitimá-las para disputar os fundos públicos, e depreciando a educação pública a partir da baixa qualidade e de supostos custos elevados. Tais argumentos foram sendo refutados a partir dos números e estudos realizados pelas entidades ligadas à educação e à pesquisa tornando públicas a opacidade das informações oficiais ou mesmo sua inexistência. Desta maneira a representação construída em torno da polaridade escola privada de qualidade e escola pública ruim foi sendo desconstituída

O segundo movimento realizado pretendeu retomar a discussão sobre a responsabilidade em relação ao dever de educar, se da família ou do Estado.

O deslizamento discursivo, nesse caso, se opera em torno da questão da liberdade e do direito. Inicialmente os setores privatistas defenderam que a família deveria ter a liberdade de escolher a escola na qual deveriam estudar seus filhos, nesse caso ao Estado caberia financiar tal escolha. Depois passaram a defender que a "criança carente" teria o "direito" de estudar em uma escola privada, razão pela qual as instituições de ensino privadas não deveriam ser "marginalizadas" do acesso às verbas públicas.

No transcorrer dos debates, particularmente no âmbito da Comissão de Sistematização, operou-se um terceiro movimento que pretendeu resignificar o sentido do público, isto é a educação deixaria de ser apresentada como um direito para tornar-se uma prestação de serviço que poderia tanto ser oferecido por instituições públicas como privadas.

Os setores privatistas reconfiguraram várias vezes seu discurso, lançando mão das mais expressivas representações do ideário liberal, empenharam-se em 
atender os interesses dos setores mais conservadores da Igreja Católica, e, ao mesmo ampliar ao máximo o acesso aos fundos públicos.

Outro campo onde a disputa ideológica e semântica se revelou marcante diz respeito à municipalização e as responsabilidades dos entes federados. Desde os debates iniciais na Subcomissão a municipalização foi identificada com a descentralização de poder e, sobretudo, de recursos sendo, por isso, apresentada como alternativa para a gestão da educação infantil e do ensino fundamental no País. A ideia de descentralização, por sua vez, foi apresentada como capaz de ensejar maior participação social dos cidadãos em função da proximidade física, no território, entre governos e cidadãos. Aparecendo como mais democrática a descentralização

A municipalização se adequava tanto aos preceitos neoliberais, que defendiam menor participação do Estado no financiamento das políticas públicas, como atendia aos interesses imediatos das instituições privadas na medida em que estando sob o controle da esfera municipal, e fora dos mecanismos de controle nacional, poderiam pleitear com maior facilidade bolsas de estudo, para atender a demanda e suprir as efetivas dificuldades de garantia de vagas, particularmente no caso do ensino fundamental e médio. Por isso se explica que no âmbito da Comissão de Sistematização tenha surgido a proposta de que ficasse sob a responsabilidade de cada estado, com seus municípios, estabelecer em Lei Complementar as responsabilidades em relação a estes dois níveis de ensino. $O$ empenho era o de se conseguir melhores condições para acessar os fundos públicos e diminuir os riscos dos empreendimentos capitalistas no campo do ensino.

Entretanto, malgrado todos os esforços dos setores privatistas e de seus aliados, entre os constituintes da chamada centro-direita, a afirmação de direitos ganhou presença, expressão, visibilidade e força, ampliando a esfera pública e, por isso, tornando-os incontornáveis.

Podemos considerar que as ideias de carência e necessidade tão caras ao ideário liberal foram sendo substituídas, ao longo dos debates e na maioria dos anteprojetos propostos, pela garantia de direitos e de cidadania. O exercício dos direitos gerou e instituiu direitos 
O detalhado exame das atas e dos anteprojetos - fontes que constituíram o corpus documental desta pesquisa - revelou que foram sendo criados mecanismos para a oferta de ensino público em instituições oficiais em todos os níveis de ensino, em sintonia com o sentido do inciso IV do art. 206 do texto final.

O inciso I do art. 208 que estabeleceu a garantia do ensino fundamental, obrigatório e gratuito, inclusive para os que a ele não tiveram acesso na idade própria, embora não previsse que esse direito fosse assegurado em estabelecimentos oficiais, estava relacionado ao parágrafo $1^{\circ}$ e $2^{\circ}$ do inciso VII do art. 208. Respectivamente estabeleciam o acesso ao ensino obrigatório e gratuito como direito público subjetivo e a responsabilização da autoridade competente em caso de não-oferecimento do ensino obrigatório pelo poder público.

O parágrafo $5^{\circ}$ do art. 212 estabeleceu o salário educação como fonte adicional de financiamento do ensino fundamental público ampliando as condições de atendimento além dos recursos vinculados previstos no caput do art. 212.

A previsão de atendimento em creches e pré-escolas de zero a seis anos, de atendimento educacional especializado aos alunos com deficiência, preferencialmente na rede regular de ensino, o direito ao ensino noturno regular, adequado às condições do educando e a progressiva extensão da obrigatoriedade e gratuidade ao Ensino Médio foram conquistas que ampliavam as condições de luta pela apropriação dos fundos públicos para a educação pública.

Entre as definições constitucionais merece destaque o princípio da garantia de padrão de qualidade para o ensino (inciso VII do art. 206) perspectiva que criava uma ruptura com o discurso que pretendia naturalizar e perpetuar os problemas da educação pública.

Se a previsão de recursos públicos para as escolas comunitárias, confessionais ou filantrópicas (caput do art. 213), assim como a previsão de bolsas de estudo para o ensino fundamental e médio em casos de insuficiência de recursos e falta de vagas e cursos regulares da rede pública (parágrafo $1^{\circ}$ do inciso II do art. 213) representava uma vitória dos setores privatistas é certo as condições de acesso aos recursos públicos teria como limite os direitos inéditos assegurados no texto constitucional. 
Ademais, transformar as definições constitucionais em políticas educacionais encontrava amparo tanto na definição de competências dos entes federados quanto do regime de colaboração entre eles, de acordo com o caput e os parágrafos $1^{\circ}$ e $2^{\circ}$ do art. 211.

A educação, concebida como direito de todos e dever do Estado e da família, teria ainda como instrumento de planejamento, visando à articulação dos níveis de ensino e das ações do poder público, o Plano Nacional de Educação com previsão de duração plurianual (art. 214)

Assim, não parece suficiente analisar a Constituição de 1988 apenas pelo que the falta.

A ideia de uma Constituição inacabada permite inferir que a República, a justiça social e a democracia não seriam alcançáveis nos países dependentes de tradição colonial como o Brasil e que aos setores excluídos restaria apenas uma conduta de permanente denúncia frente às desigualdades, assimetrias e violências, o que a História desmentiu.

A lei não tem força sem ação política e, portanto, a luta por direitos não se esgotaria com as definições constitucionais. Ao contrário, ela demarcava fundamentos para a elaboração da Lei de Diretrizes e Bases e para que o Brasil pudesse pensar em uma política nacional de longo prazo, por meio do Plano Nacional de Educação.

A presente pesquisa permitiu identificar um vasto campo de temas e de questões que desafiam os investigadores como a relação entre os partidos políticos e as entidades, organizações e movimentos da sociedade civil que atuaram no processo Constituinte. Da mesma forma resta a necessidade de novos estudos que aprofundem a compreensão sobre o significado das emendas apresentadas, sobretudo aquelas que derivam da mobilização e organização popular autônoma, nas circunstâncias históricas específicas da conjuntura dos anos 1985 a 1988 . No mesmo sentido cabe também indicar a importância de que seja melhor investigado o papel dos intelectuais no processo constituinte, no caso da educação merece destaque o entrelaçamento entre a produção teórica dos pesquisadores e a produção coletiva desenvolvida pelo Fórum da Educação na Constituinte em Defesa da Escola Pública e Gratuita. 
Por fim, é consensual que as concepções neoliberais além de permanecerem à frente no Estado brasileiro se fortaleceram junto às dinâmicas do sistema capitalista. Nesse quadro, a Constituição de 1988 - "salgada e molhada" -, bem como a experiência social a partir dela constituída, permitiram a, conquista de instrumentos de proteção social e a garantia de direitos para diferentes setores da sociedade brasileira, especialmente para os trabalhadores. que se tornariam referências para a inescapável luta contra as desigualdades, a violência e assimetrias sociais e regionais.

A educação, nas letras da Constituição, se tornava um direito e, como questão nacional, um vasto e desafiador campo de luta pelo acesso à cultura e pela conquista da liberdade. 


\section{BIBLIOGRAFIA E FONTES}

ABICALIL, Carlos Augusto. Plano Decenal de Educação para Todos: um cenário para muitos atores. Em aberto, Brasília, ano 13, n.59, p.37-41, jul./set. 1993.

ADERALDO, Vanda Maria C. ESG: um estudo de currículos e programas. Dissertação de Mestrado, IUPERJ, Rio de Janeiro, 1978

ALVES, Antonio; VIANA, Jorge. A República do Acre. In: ALVES, Antonio. Artigos em geral. Rio Branco: Valor, 2004.

ALVES, Márcio Moreira. Beabá dos MEC-USAID. Rio de Janeiro: Gernasa, 1968.

ALVES, Maria Helena Moreira. Estado e Oposição no Brasil (1964-1984). Petrópolis: Vozes, 1984.

ANTONACCI, Maria Antonieta. Cultura, trabalho, meio ambiente: estratégias de "empate" no Acre. In: Revista Brasileira de História, v. 14, n. 28, [1994]. Disponível em:

<http://www.anpuh.org/revistabrasileira/view?ID REVISTA BRASILEIRA=15>. Acesso em: 29 nov. 2014

ASSOCIAÇÃO NACIONAL DE EDUCAÇÃO; ASSOCIAÇÃO NACIONAL DE PESQUISA E PÓS-GRADUAÇÃO EM EDUCAÇÃO; CENTRO DE ESTUDOS EDUCAÇÃO E SOCIEDADE. Carta de Goiânia. In: IV Conferência Brasileira de Educação. Goiânia, 1986. Anais da IV Conferência Brasileira de Educação (t. 2). São Paulo: Cortez, 1988. Disponível em: <http://www.cedes.unicamp.br/carta goiania.pdf>. Acesso em: 22 nov. 2014.

ANDERSON, Benedict. Comunidades imaginadas: reflexões sobre a origem e a difusão do nacionalismo. São Paulo: Companhia das Letras, 2008.

ANDERSON, Perry. Zona de compromisso. São Paulo: Editora da Unesp, 1996.

ANPED. Parecer da ANPEd sobre a proposta elaborada pelo MEC para o Plano Nacional de Educação. São Paulo, dezembro de 1997.

ARAPIRACA, José Oliveira. A USAID e a educação brasileira. São Paulo: Cortez, 1982.

ARENDT, Hanna. Entre o passado e o futuro. São Paulo: Perspectiva, 2007. . A dignidade da política. Rio de Janeiro: Relume Dumará, 1993.

A condição humana. Rio de Janeiro: Forense Universitária, 2014.

ARRUDA, Antonio. ESG: História de sua doutrina. São Paulo; Brasília: GDR; Instituto Nacional do Livro; MEC, 1980. 
ASSUNÇÃO, Vânia Noeli Ferreira de. Ditadura como bonapartismo: apreensões marxistas sobre o regime inaugurado em 1964. Verinotio - revista on-line de filosofia e ciências humanas, n. 17, Ano XI, abr. 2013.

AZEVEDO, Fernando de. Cultura brasileira: introdução ao estudo da cultura no Brasil.São Paulo: Companhia Editora Nacional, 1944.

BACKES, Ana Luiza; AZEVEDO, Débora Bithiah de; ARAÚJO, José Cordeiro de (orgs.). Audiências Públicas na Assembleia Nacional Constituinte: a Sociedade na Tribuna. Brasília: Câmara dos Deputados, 2009 (3 v.).

BALAKRISHNAN, Gopal (org.). Um mapa da questão nacional. Rio de Janeiro: Contraponto, 2008.

BASBAUM, Leôncio. História sincera da República. São Paulo: Alfa-Ômega, 1991.

BARROS, Alexandre S. C. Formando elites. Jornal da Tarde, São Paulo, 25.08.1979.

BHABHA, $\mathrm{H}$. Disseminação: o tempo, a narrativa e as margens da nação moderna. In: O Local da Cultura. Belo Horizonte: Editora da UFMG, 2001.

BICUDO, Hélio. Segurança nacional ou submissão. São Paulo: Paz e Terra, 1984.

BLOCH, Marc. Apologia da História: ou o ofício de historiador. Rio de Janeiro: Jorge Zahar Editor, 2001.

BOBBIO, Norberto. Estado, governo, sociedade: para uma teoria geral da política. Rio de Janeiro: Paz e Terra, 2011.

. O futuro da democracia: uma defesa das regras do jogo. Rio de Janeiro: Paz e Terra, 1986.

. A era dos Direitos. Rio de Janeiro: Campus, 1992.

. As ideologias e o poder em crise. Brasília: Editora UNB, 1999.

. Teoria Geral da Política. Rio de Janeiro: Elsevier, 2000.

2001.

. Entre duas Repúblicas: às origens da democracia italiana. Brasília: UNB,

Qual democracia? São Paulo: Loyola, 2010.

. Liberalismo e democracia. São Paulo: Brasiliense, 2013.

BOLAÑO, César. "Considerações sobre o conceito de cultura em Celso Furtado". In: D'AGUIAR, Rosa Freire. Celso Furtado e a dimensão cultural do desenvolvimento. Rio de Janeiro: E-papers; Centro Internacional Celso Furtado, 2013.

BOSI, Alfredo. A educação e a cultura nas Constituições brasileiras. Novos Estudos 
CEBRAP, São Paulo, no 14, fev. 1986.

Presença de Florestan Fernandes, Revista Estudos Avançados, São Paulo: IEA/USP, v. 10, n. 26, 1996.

BOTO Carlota. A Escola do homem novo. São Paulo: Editora UNESP, 1996.

BOURDIEU, Pierre (coord.). A miséria do mundo. Petrópolis: Vozes, 2012.

BOURDIEU, Pierre. A economia das trocas simbólicas. São Paulo: Perspectiva, 2013.

BRASIL. Constituição da República dos Estados Unidos do Brasil. 1824. Disponível em:

$<$ http://www.camara.gov.br/Internet/InfDoc/conteudo/colecoes/Legislacao/Const 182 4.pdf >. Acessado em: 30 nov. 2014.

. Lei 3.071, de 1ํ de janeiro de 1916. Disponível em:

<http://www.soleis.adv.br/direitodefamiliacodcivil.htm>. Acesso em: 30 nov. 2014.

. Constituição da República dos Estados Unidos do Brasil. 1934.

Disponível em: <http://www2.camara.leg.br/legin/fed/consti/1930-1939/constituicao1934-16-julho-1934-365196-publicacaooriginal-1-pl.html>. Acesso em: 30 nov. 2014.

. Constituição da República dos Estados Unidos do Brasil. 1937.

Disponível em: http://www2.camara.leg.br/legin/fed/consti/1930-1939/constituicao-

35093-10-novembro-1937-532849-publicacaooriginal-15246-pe.html. Acesso em: 30 nov. 2014.

. Constituição dos Estados Unidos do Brasil, 1946. Disponível em:

$<$ http://www2.camara.leg.br/legin/fed/consti/1940-1949/constituicao-1946-18-julho1946-365199-publicacaooriginal-1-pl.html>. Acesso em: 30 nov. 2014

. Lei no 4.024, de 20 de dezembro de 1961. Disponível em:

<http://www2.camara.leg.br/legin/fed/lei/1960-1969/lei-4024-20-dezembro-1961353722-publicacaooriginal-1-pl.html>. Acesso em: 30 nov. 2014.

Lei 4.440, de 27 de outubro de 1964. Disponível em: $<$ http://www2.camara.leg.br/legin/fed/lei/1960-1969/lei-4440-27-outubro-1964376713-publicacaooriginal-1-pl.html>. Acesso em: 30 nov. 2014.

. Constituição da República Federativa do Brasil. 1967. Disponível em: $<$ http://www2.camara.leg.br/legin/fed/consti/1960-1969/constituicao-1967-24-janeiro1967-365194-publicacaooriginal-1-pl.html>. Acesso em: 30 nov. 2014.

Lei 5.540, de 28 de novembro de 1968a. Disponível em: <http://www2.camara.leg.br/legin/fed/lei/1960-1969/lei-5540-28-novembro-1968359201-publicacaooriginal-1-pl.html>. Acesso em: 30 nov. 2014. 
. Ato Institucional $n^{\circ}$ 5, de 13 de dezembro de 1968b. Disponível em:

07/2014<http://www.planalto.gov.br/ccivil 03/AIT/ait-05-68.htm>. Acessado em: 30 nov. 2014.

Decreto-lei 477, de 26 de fevereiro de 1969a. Disponível em: $<$ http://www2.camara.leg.br/legin/fed/declei/1960-1969/decreto-lei-477-26fevereiro-1969-367006-norma-pe.html>. Acesso em: 30 nov. 2014.

. Decreto-Lei ํo 872, de 15 de setembro de 1969b. Disponível em: $<$ https://www.planalto.gov.br/ccivil 03/Decreto-Lei/1965-1988/Del0872.htm>. Acesso em: 30 nov. 2014.

. Emenda Constitucional o 1/69, de 17 de outubro de 1969c. Disponível em: $\quad<h t t p: / / w w w 2 . c a m a r a . l e g . b r / l e g i n / f e d / e m e c o n / 1960-$ 1969/emendaconstitucional-1-17-outubro-1969-364989-republicacao-28547pl.html>. Acesso em: 30 nov. 2014.

- Lei 5.692, de 11 de agosto de 1971. Disponível em: http://www.camara.gov.br/sileg/integras/136683.pdf. Acesso em: 30 nov. 2014.

- Decreto 88.374, de 7 de junho de 1983a. Disponível em: < http://www2.camara.leg.br/legin/fed/decret/1980-1987/decreto-88374-7-junho1983-438124-publicacaooriginal-1-pe.html>. Acesso em: 30 nov. 2014.

. Emenda Constitucional $\mathrm{n}^{\circ} 24 / 83$, de $1^{\circ}$ de dezembro de 1983b. Disponível em: $\quad<h t t p: / / w w w 2 . c a m a r a . l e g . b r / l e g i n / f e d / e m e c o n / 1980-$ 1987/emendaconstitucional-24-1-dezembro-1983-364949-publicacaooriginal-1pl.html>. Acesso em: 30 nov. 2014

- Lei 7.348, de 24 de julho de 1985. Disponível em: $<$ http://www.planalto.gov.br/ccivil 03/leis/1980-1988/L7348.htm>. Acesso em: 30 nov. 2014.

. I Plano Nacional de Desenvolvimento da Nova República - 1986-1989. Brasília, 1986.

. Constituição da República Federativa do Brasil. 1988. Disponível em: $<$ http://www.senado.leg.br/legislacao/const/con1988/CON1988 05.10.1988/CON198 8.pdf>. Acesso em: 30 nov. 2014.

. Emenda Constitucional $n^{\circ}$ 14/96, de 12 de setembro de 1996. Disponível em: <http://portal.mec.gov.br/arquivos/pdf/e1496.pdf>. Acesso em: 30 nov. 2014.

- Lei 9.424, de 24 de dezembro de 1996. Disponível em: <http://www.planalto.gov.br/ccivil 03/leis/l9424.htm>. Acesso em: 30 nov. 2014.

Lei 9.394 de 20 de dezembro de 1996. Disponível em: <http://www.planalto.gov.br/ccivil 03/leis//9394.htm>. Acesso em: 30 nov. 2014. 
. Lei 10.406, de 10 de janeiro de 2002. Disponível em: $<$ http://www.planalto.gov.br/ccivil 03/leis/2002//10406.htm>. Acesso em: 30 nov. 2014.

BRASIL. Assembleia Nacional Constituinte. Anteprojeto Constitucional. Diário Oficial da União, Suplemento Especial ao no 185, 26 set, 1986. Disponível em: $<$ http://www.senado.gov.br/publicacoes/anais/constituinte/AfonsoArinos.pdf >.

Acesso em: 30 nov. 2014.

- Resolução $\mathrm{n}^{\circ}$ 2, de 25 de março de 1987a. Disponível em: $<$ http://www2.camara.leg.br/legin/fed/resaco/1980-

1987/resolucaodaassembleianacionalconstituinte-2-25-marco-1987-592261normaatualizada-pl.html> Acesso em: 30 nov. 2014.
v. 207
207, $1987 \mathrm{~b}$.
$<$ http://www.camara.gov.br/internet/constituicao20anos/DocumentosAvulsos/vol-
207.pdf>. Acesso em: 30 nov. 2014.

Disponível

tes,

Substitutivo do relator da Comissão da Família, da Educação, Cultura e Esportes, da Ciência e Tecnologia e da Comunicação, v. 202, 1987c. Disponível em: <http://www.camara.gov.br/internet/constituicao20anos/DocumentosAvulsos/vol202.pdf>. Acesso em: 30 nov. 2014.

- Substitutivo do relator da Comissão da Família, da Educação, Cultura e Esportes, da Ciência e Tecnologia e da Comunicação, v. 204, 1987d. Disponível em: $<$ http://www.camara.gov.br/internet/constituicao20anos/DocumentosAvulsos/vol204.pdf >. Acesso em: 30 nov. 2014.

Substitutivo do relator da Comissão da Família, da Educação, Cultura e Esportes, da Ciência e Tecnologia e da Comunicação (nova redação), v. 205, 1987e. Disponível em: $<$ http://www.camara.gov.br/internet/constituicao20anos/DocumentosAvulsos/vol205.pdf $>$. Acesso em: 30 nov. 2014.

Anteprojeto da Comissão da Família, da Educação, Cultura e Esportes, da Ciência e Tecnologia e da Comunicação, v. 206, 1987f. Disponível em: $<$ http://www.camara.gov.br/internet/constituicao20anos/DocumentosAvulsos/vol206.pdf>. Acesso em: 30 nov. 2014.

Atas das Comissões. Diário da Assembleia Nacional Constituinte, Brasília, ano I, Suplemento ao $\mathrm{n}^{\circ}$ 118, 8 ago. 1987g. Disponível em: $<$ http://imagem.camara.gov.br/lmagem/d/pdf/sup118anc08ago1987.pdf $>$. Acesso em: 30 nov. 2014.

Anteprojeto de Constituição, v. 219, 1987h. Disponível em: $<$ http://www.camara.gov.br/internet/constituicao20anos/DocumentosAvulsos/vol219.pdf>. Acesso em: 30 nov. 1987. 
Atas da Comissão da Família, da Educação, Cultura e Esportes, da Ciência de Tecnologia e da Comunicação. Anais da Assembleia Nacional Constituinte 1987-1988. Brasília, 1988a Disponível em: $<$ http://www2.camara.leg.br/atividadelegislativa/legislacao/Constituicoes Brasileiras/constituicaocidada/publicacoes/anais-da-assembleia-nacional-constituinte>. Acesso em: 30 nov. 2014.

Atas da Subcomissão de Educação Cultura e Esportes. Anais da Assembleia Nacional Constituinte 1987-1988. Brasília, 1988b Disponível em: $<$ http://www2.camara.leg.br/atividadelegislativa/legislacao/Constituicoes Brasileiras/constituicaocidada/publicacoes/anais-da-assembleia-nacional-constituinte>. Acessado em: 30 nov. 2014.

Resolução no 3, de 1988c. Disponível em: $<$ http://www2.camara.leg.br/atividadelegislativa/legislacao/Constituicoes Brasileiras/constituicaocidada/publicacoes/regimento-interno-da-assembleia-nacional/resolucao-3-1987>. Acesso em: 30 nov. 2014.

- O processo histórico da elaboração do texto constitucional: mapas demonstrativos. Brasília: Câmara dos Deputados, Coordenação de Publicações, 1993. Disponível em: <http://www2.camara.leg.br/atividadelegislativa/legislacao/Constituicoes Brasileiras/constituicao-cidada/publicacoes/oprocesso-historico-da-elaboracao-do-texto-1>. Acesso em: 12 mai. 2015.

BRASIL. Câmara dos Deputados. 25 anos da Constituição Cidadã: biografias.

BRASIL. Ministério da Educação. Reforma Universitária - Relatório do Grupo de Trabalho. Diário Oficial da União, 23 ago. 1968.

- Dia nacional de debate sobre educação: síntese e perspectivas. São Paulo: CENAFOR, 1985a.

. Educação para Todos: caminhos para mudança. Brasília: 1985b.

- Programa setorial de ação do governo Collor na área de educação 1991-1995. Brasília, 1990.

. Plano Decenal de educação para todos. Brasília, 1993.

. Desenvolvimento da educação no Brasil.1996.

. Programa toda criança na escola. Brasília, 1997

. Balanço das realizações - 1993. Brasília, s.d.

1994.

. Conferência Nacional de Educação para todos: Anais. SEF: Brasília, 
. Programa Nacional de Alfabetização e cidadania: marcos de referência. Brasília, 1991.

BRASLAVSKY, Cecília. "Evolución de los sistemas educativos en los processos de transición a la democracia". In: UNESCO; OREALC. Educación en la transición a la democracia: casos de Argentina, Brasil e Uruguay. Santiago de Chile: 1989.

CADEMARTORI, Lígia (org.). O desafio da escola básica: qualidade e equidade. Brasília: IPEA, 1991.

CÂNDIDO, Antonio. "Uma palavra instável". Folha de São Paulo, Caderno Mais, 27.08.1995.

. CANDIDO, Antonio. O jovem Florestan. Revista Estudos Avançados, São Paulo, IEA/USP, v. 10, n. 26, 1996.

CARDOSO, Fernando Henrique. Regime político e mudança social: algumas reflexões a propósito do caso brasileiro. Revista de Cultura e Política, São Paulo, n.3, 1981.

CARDOSO, Miriam Limoeiro. Ideologia do desenvolvimento: Brasil, JK/JQ. Rio de Janeiro: Paz e Terra, 1978.

CARONE, Edgard. A quarta República (1945-1964). São Paulo: Difel, 1980.

A república liberal: instituições e classes sociais.São Paulo: Difel, 1981.

CARVALHO, Jose Murilo de. Forças Armadas e política no Brasil. Rio de Janeiro: Zahar, 1980. 2013.

Cidadania no Brasil: o longo caminho. Rio de Janeiro: Civilização Brasileira,

A formação das almas: o imaginário da República no Brasil. São Paulo: Companhia das Letras, 2013.

CARVALHO, José Sérgio. Reflexões sobre educação, formação e esfera pública. Porto Alegre: Penso, 2013.

CARVALHO, Marta Maria Chagas de. A escola e a republica. São Paulo: Brasiliense, 1989.

CASTELO BRANCO, Carlos. A revolução de 31 de Março. Rio de Janeiro: Biblioteca do Exército, 1966.

Os militares no poder. Rio de Janeiro: Nova Fronteira, 1976.

CASTELO BRANCO, Humberto de Alencar. A revolução e o comunismo. Brasília: Departamento de Imprensa Nacional, 1964 (Discurso). 
CASTRO, Celso; D'ARAUJO, Maria Celina (orgs.). Dossiê Geisel. Rio de Janeiro: Fundação Getúlio, 2002.

CEPAL. Educación y conocimiento: eje de la transformación productiva con equidad.UNESCO: Santiago de Chile, 1992.

CEPAL; UNESCO. Educação e conhecimento: eixo da transformação produtiva com equidade. Brasília: IPEA/CEPAL/INEP, 1995.

CERTEAU, Michel de. A escrita da história. São Paulo; Rio de Janeiro: Forense Universitária, 2008.

CHAUÍ, Marilena. "Apontamentos para uma crítica da Ação Integralista Brasileira". In: CHAUÍ, Marilena; FRANCO, Maria Sylvia de C. Ideologia e mobilização popular. Rio de Janeiro: CEDEC; Paz e Terra, 1978.

. Cultura e democracia. São Paulo: Cortez, 1993.

. Cultura política e política cultural. Estudos Avançados. São Paulo, v. 9, n. 23, abr. $1995 . \quad$ Disponível em:

$<$ http://www.scielo.br/scielo.php?script=sci arttext\&pid=S0103-

40141995000100006\&lng=en\&nrm=iso\&tlng=pt>. Acesso em: 05 jul. 2014.

- Manifestações ideológicas do autoritarismo brasileiro. Belo Horizonte: Autentica Editora. São Paulo: Editora Fundação Perseu Abramo, 2013a.

- Contra a servidão voluntária. Belo Horizonte: Autentica Editora. São Paulo: Editora Fundação Perseu Abramo, 2013b.

. A ideologia da competência. Belo Horizonte: Autentica Editora. São Paulo: Editora Fundação Perseu Abramo, 2013c.

COMPARATO, Fábio Konder. Educação, estado e poder. São Paulo: Brasiliense, 1987.

COSTA, João Cruz. Esboço de uma historia das idéias no Brasil na primeira metade do século XX (II). Revista de História, São Paulo, FFLCH, n.20, 1954 (Separata).

COSTA, João Cruz. Contribuições à historia das idéias no Brasil. Rio de Janeiro: José Olympio, 1956.

COUTO E SILVA, Golbery do. Planejamento estratégico. Brasília: Editora da UNB, 1981a. . Conjuntura política nacional: o poder executivo e a geopolítica do Brasil. Rio de Janeiro: Jose Olympio, $1981 b$.

CUNHA. Antônio Geraldo. Dicionário Etimológico da Língua Portuguesa. Rio de Janeiro: Lexikon, 2012.

CUNHA, Luiz Antônio. Educação e desenvolvimento social no Brasil. Rio de Janeiro: 
Francisco Alves, 1980.

. A universidade crítica. Rio de Janeiro: Francisco Alves, 1983.

. Educação Brasileira: projeto em disputa. São Paulo: Cortez, 1995.

. A universidade reformada: o golpe de 1964 e a modernização do ensino superior. São Paulo: UNESP, 2007.

. Educação, Estado e democracia no Brasil. São Paulo: Cortez, 2009.

CURY, Carlos Roberto Jamil et al. A profissionalização do ensino na Lei no 5.692/71. Trabalho apresentado pelo INEP à XVIII Reunião Conjunta do Conselho Federal de Educação com os Conselhos Estaduais de Educação. Brasília, 1982.

CURY, Carlos Roberto Jamil. Educação e contradição: elementos metodológicos para uma teoria crítica do fenômeno educativo. São Paulo: Cortez - Autores Associados, 1985.

. Lei de Diretrizes e Bases da Educação Nacional (versão base preliminar). XX Reunião Anual da Associação Nacional de Pesquisa e Pós-Graduação em Educação. Caxambu, set. 1997.

. "A Educação e a Primeira Constituinte Republicana". In: FÁVERO, Osmar (org.). A educação nas constituintes brasileiras(1823-1988). Campinas: Autores Associados, 2005.

. "Projetos republicanos e a questão da educação nacional". In: VAGO, T. M.; et AL. (orgs.) Intelectuais e escola pública no Brasil: séculos XIX e XX. Belo Horizonte: Mazza Edições, 2009.

DA CUNHA, Célio. Plano Decenal: fundamentos, trajetória e alcance social.Em Aberto, Brasília, ano 13, n. 59, p. 24-35, jul./set. 1993.

DAGNINO, Evelina (org.). Anos 90: política e sociedade no Brasil. São Paulo: Brasiliense, 1994.

D'ARAUJO, Maria Celina; CASTRO, Celso (orgs.). Ernesto Geisel. Rio de Janeiro: Fundação Getúlio, 1997.

DE TOMMASI, Lívia; WARDE, Mirian Jorge; HADDAD, Sérgio (orgs). O Banco Mundial e as políticas educacionais. São Paulo: Cortez, Ação Educativa, PUC-SP, 1996.

DEBERT, Guita G. O nacionalismo da Escola Superior de Guerra. mimeo. (Texto apresentado à ANPOCS), 1984.

A política do significado no inicio dos anos 60: o nacionalismo no Instituto Superior de Estudos Brasileiros (ISEB) e na Escola Superior de Guerra (ESG), São Paulo. Tese de Doutorado. Departamento de Ciências Sociais, FFLCH/USP, 1986. 
DEBRUN, Michel. Ideologia e realidade. Rio de Janeiro: Instituto Superior de Estudos Brasileiros (MEC), 1959.

DINIZ, Eli; AZEVEDO, Sergio (orgs.) Reforma do Estado e democracia no Brasil. Brasília: Editora da Universidade de Brasília, 1997.

DINIZ, Eli; AZEVEDO, Sergio; CAMARGO, Aspásia (orgs.). Continuidade e mudança no Brasil da Nova República. São Paulo: Vértice, Editora dos Tribunais, 1989.

DREIFUSS, René Armand. 1964: A conquista do Estado - Ação política, poder e golpe de classe. Petrópolis: Vozes, 1987.

DUARTE, Clarice Seixas. Direito público subjetivo e políticas educacionais. São Paulo em Perspectiva. São Paulo, v. 18, n. 2, jun. 2004. Disponível em: $<$ http://www.scielo.br/scielo.php?script=sci pdf\&pid=S010288392004000200012\&lng=en\&nrm=iso\&t|npt>. Acesso em: 29 nov. 2014.

DULLES, John W. F. Castelo Branco: o caminho para a presidência. Rio de Janeiro: Jose Olympio, 1979.

ESCOLA SUPERIOR DE GUERRA. Departamento de Estudos. Manual Básico, 1975.

ESTADO-MAIOR DO EXÉRCITO. História do exército brasileiro: perfil militar de um povo. Rio de Janeiro: Biblioteca do Exército, 1972.

ESTADO-MAIOR DO EXÉRCITO. História do Estado-Maior do Exército. Rio de Janeiro: Biblioteca do Exército, 1984.

FAORO, Raymundo. O Estado novo do PMDB. Revista Senhor, São Paulo, n. 250/251, dez. 1985.

A aventura liberal numa ordem patrimonialista. Revista USP, Dossiê liberalismo/neoliberalismo, São Paulo, n.17, mar./abr./mai. 1993.

. A república inacabada. São Paulo: Globo, 2007.

A democracia traída: entrevistas. São Paulo: Editora Globo, 2008.

FAGNANI, Eduardo. Política social no Brasil (1964-2002): entre a cidadania e a caridade. Tese de Doutorado, Instituto de Economia da Unicamp, Campinas, 2005.

FARENZENA, Nalu. Diretrizes da política de financiamento da educação básica Brasileira: continuidades e inflexões no ordenamento constitucional-legal (19871996). Tese de Doutorado. Universidade Federal do Rio Grande do Sul. Faculdade de Educação. Programa de Pós-Graduação em Educação. Porto Alegre, 2001. 
FÁVERO, Osmar (org.). A educação nas constituintes brasileiras (1823-1988). Campinas: Autores Associados, 2005.

FERNANDES, Florestan. Os circuitos da história. São Paulo: Hucitec, 1977. . O processo constituinte. Brasília: Câmara dos Deputados, 1988.

. A Constituição inacabada: vias históricas e significado político. São Paulo: Estação Liberdade, 1989.

. A revolução burguesa no Brasil. Rio de Janeiro: Guanabara, 1987.

. Capitalismo dependente e classes sociais na América Latina. São Paulo: Global, 2009.

. A integração do negro na sociedade de classes: o legado da "raça branca". São Paulo: Globo, 2008.

. Sociedade de classes e subdesenvolvimento. São Paulo: Global, 2008.

. Florestan Fernandes na Constituinte: leituras para a reforma política. São Paulo: Fundação Perseu Abramo; Expressão Popular, 2014.

FERREIRA, Oliveiros S. As Forças Armadas e o desafio da revolução. Rio de Janeiro: Edições GRD, 1964.

. "A Escola Superior de Guerra no quadro do pensamento político brasileiro". In: As idéias políticas no Brasil. São Paulo: Editora Convívio, 1979.

. Forças Armadas para quê? São Paulo: Edições GRO, 1988.

FIGUEIREDO, Argelina; LIMONGI, Fernando. Executivo e Legislativo na nova Ordem Constitucional. Rio de Janeiro: FGV Editora, 1999.

FILMUS, Daniel. Estado, sociedad y educación em La Argentina de fin de siglo: proceso y desafios. Buenos Aires: Troquel, 1999.

FÓRUM DA EDUCAÇÃO NA CONSTITUINTE. "Proposta educacional para a Constituição". Revista Brasileira de Estudos Pedagógicos. Brasília, 68 (160): 665-8, set./dez. 1987.

Proposta educacional para a Constituição. Revista Brasileira de Estudos Pedagógicos, Brasília, v. 68, n.160, pp. 665-8, set.-dez. 1987,

FRANÇA. Assembleia Nacional. Declaração dos Direitos do Homem e do Cidadão, 1789. Disponível em: <http://pfdc.pgr.mpf.mp.br/atuacao-e-conteudos-deapoio/legislacao/direitos-humanos/declar dir dev homem.pdf> Acessado em: 11 mar. 2014. 
FRANÇA. Convenção Nacional. Declaração dos Direitos do Homem e do Cidadão, 1793. Disponível em: <http://www.dhnet.org.br/direitos/anthist/dec1793.htm>. Acesso em: 11 mar. 2014.

FREIRE, Paulo. Educação como prática da liberdade. São Paulo: Paz e Terra, 2000. . Pedagogia do Oprimido. São Paulo: Paz e Terra, 2007. . Pedagogia da Autonomia. São Paulo: Paz e Terra, 2011.

FREITAG, Bárbara. Escola, estado e sociedade. São Paulo: EDART, 1978.

FRIGOTTO, Gaudêncio. O contexto sócio-político brasileiro e a educação na década de 70-90. Contexto e Educação, Universidade de ljuí, out./dez. 1991, p. 43-57.

FURTADO, Celso. Ensaios sobre cultura e o Ministério da Cultura. Rio de Janeiro: Contraponto, 2012.

GARCIA, Tânia Cristina Meira. Estado e descentralização da educação no Brasil: a política educacional no Ceará (1987-1996). 1997, Dissertação de Mestrado, Universidade Federal do Ceará, Fortaleza.

A próxima atração. O Povo. Fortaleza, 25 de abril de 1998.

GARRIDO, Maria do Céu Jurema; GOMES, Cândido Alberto. "A educação na Assembléia Constituinte". Revista Brasileira de Estudos Pedagógicos. Brasília, 68 (160): 669-99, set./dez. 1987.

GENTILI, Pablo A. A.; DA SILVA, Tomaz Tadeu (orgs.). Neoliberalismo, qualidade total e educação: visões críticas.Petrópolis: Vozes, 1994.

GERMANO, José Willington. Estado Militar e educação no Brasil (1964-1985). São Paulo: Cortez, 1993.

GHIRALDELLI Jr., Paulo. História da educação. São Paulo: Cortez, 1990.

GOMES, Cândido Alberto. A educação no Brasil nos anos 90. Brasília: UNICEF, 1997, (mimeografado).

GOMES, Cândido Alberto; AMARAL SOBRINHO, José (orgs.). Qualidade, eficiência e equidade na educação básica. Brasília: IPEA, 1992.

GOES, Walder de. O Brasil do General Geisel. Rio de Janeiro: Nova Fronteira, 1978.

GRAMSCI, Antonio. Concepção dialética da história. Rio de Janeiro: Civilização Brasileira, 1966. La política y el Estado moderno. Barcelona: Península, 1971. 
Brasileira, 1989.

Maquiavel, a política e o Estado moderno. Rio de Janeiro: Civilização

GURGEL, Jose Alfredo Amaral. Segurança e democracia. Rio de Janeiro: Biblioteca do Exército, 1975.

HAGE, Jorge. A educação na Constituinte. Mesa redonda promovida pelo INEP, por ocasião de seu cinqüentenário. Brasília, 24 de novembro de 1987 (transcrição de depoimento gravado).

. A nova Lei de Diretrizes e Bases da Educação Nacional. In: LDB - Lei de diretrizes e bases da educação nacional: texto aprovado na Comissão de Educação Nacional Cultura e Desporto da Câmara dos Deputados. São Paulo: ANDE - Cortez, 1990, p. 83-93.

HERNANDEZ, Leila Leite. Os filhos da terra do sol: a formação do Estado-Nação em Cabo Verde. São Paulo: Summus, 2002.

HOBSBAWM. Eric J. "Nacionalismo e marxismo". In: PINSKY, Jaime. Questão nacional e marxismo. São Paulo: Brasiliense, 1980.

. A era das revoluções (1789-1848). São Paulo: Paz e Terra, 2006.

. Nações e nacionalismo desde 1780: programa, mito e realidade. São Paulo: Paz e Terra, 2011.

A era dos extremos: breve século XX (1914-1991). São Paulo: Companhia das Letras, 2013.

KOSELLECK, Reinhart. Futuro passado: contribuição à semântica dos tempos históricos. Rio de Janeiro: Contraponto, Ed. PUC-Rio, 2006.

KUENZER, Acácia Z. Política educacional e planejamento no Brasil: os descaminhos da transição. In. KUENZER, Acacia Z. et al. Planejamento e educação no Brasil. São Paulo: Cortez, 1990.

(coord.). Política educacional nos anos 90: determinantes e propostas. Recife: Editora Universitária da UFPE, 1995.

LAGO, Ana. Nacionalismo nas Forças Armadas. (Texto apresentado a ANPOCS), 1984 (mimeo.).

LAMOUNIER, Bolívar. Formação de um pensamento político autoritário na Primeira República. Uma interpretação. In: FAUSTO, Boris (org.). História Geral da Civilização Brasileira. São Paulo: Difel, 1977, t.3, v.2, "Sociedade e Instituições (1889-1930)".

LASKI, H. J. El liberalismo europeo. México DF: Fondo de Cultura Económica, 1961. 
LASSALLE, Ferdinand. Que é uma Constituição? Brasil: eBooksBrasil, 2006. Disponível em: <http://www.ebooksbrasil.org/adobeebook/constituicaol.pdf> Acesso em: 17 mai. 2015.

LEAL, Victor Nunes. Coronelismo, enxada e voto. São Paulo: Alfa-Omega, 1976.

LEITE, Dante Moreira. O caráter nacional brasileiro. São Paulo: Livraria Pioneira Editora, 1969.

LIMA, Alceu de Amoroso et. al. Em defesa da nação ameaçada. 1980. Disponível em: < http://www.arqanalagoa.ufscar.br/pdf/recortes/R07819.pdf> Acesso em: 25 nov. 2014.

LIMA, João Alberto de Oliveira; PASSOS, Edilenice; NICOLA, João Rafael. $A$ gênese do texto da Constituição de 1988. Brasília: Senado Federal, Coordenação de Edições Técnicas, 2013 (2v.).

LIMONGI, Fernando. "O Poder executivo na constituição de 1988”. In: OLIVEN, Ruben George; RIDENTI, Marcelo; BRANDÃO, Gildo Marçal (orgs.). A Constituição de 1988 na vida brasileira. Editora Hucitec, 2008.

LYRA, Fernando. Em depoimento histórico ao JC, Fernando Lyra relembrou o processo de redemocratização: entrevista. Jornal do Comércio, Recife, 15 fev. 2013.

Disponível

em: $<$ http://jconline.ne10.uol.com.br/canal/politica/noticia/2013/02/15/em-depoimentohistorico-ao-jc-fernando-lyra-lembrou-o-processo-de-redemocratizacao-73413.php> Acesso em: 17 mai. 2015.

MANNHEIM, Karl. O pensamento conservador. In: MARTINS, José de Souza (org.). Introdução crítica à sociologia rural. São Paulo: Hucitec, 1981.

MARX, Karl. O 18 Brumário e Cartas a Kugelmann. Rio de Janeiro: Paz e Terra, 1974.

MÉDICI, Emilio Garrastazu. "Mensagem do Senhor Presidente da República ao Congresso Nacional". In: Diário Oficial do Estado de São Paulo, Suplemento especial, 28 de setembro de 1971.

MELCHIOR, José Carlos de Araújo. Financiamento da educação: subsídios à Constituinte. Revista de Financiamento da Educação, v. 1, n. 1, 2011.

MELO, Adriana Almeida Sales de. "Mudanças nas Propostas Educacionais do Estado Estrito Senso". In: NEVES, Lúcia Maria Wanderley (coord.). Política educacional nos anos 90:determinantes e propostas. Recife: Editora Universitária da UFPE, 1995, p. 47-64.

MELLO, Jaime Portella. A revolução e o governo Costa e Silva. Rio de Janeiro: Guairra Editores, 1979. 
MENEGUELLO, Rachel. PT: a formação de um partido (1979-1982). Rio de Janeiro: Paz e Terra, 1989.

. Partidos e governos no Brasil contemporâneo (1985-1995). Tese de Doutorado, Instituto de Filosofia e Ciências Humanas, Unicamp, Campinas, 1996.

MENEZES, Janaina S. S. A vinculação constitucional de recursos para a educação: os (des) caminhos do ordenamento constitucional. In: VII Jornada do HISTEDBR, Campo Grande, 2007.2 Disponível em: $<$ http://www.histedbr.fe.unicamp.br/acer histedbr/jornada/jornada7/03trab-gtgt2.htm>. Acesso em: 30 nov. 2014.

MORAES, João Quartim de. et. al. A tutela militar. São Paulo: Vértice, 1987.

MORENO, Jorge Bastos. A História de Mora, capítulo 14: 'Estou cercado, eu ataco'. O Globo, Rio de Janeiro, 14 jan. 2012. Disponível em: $<$ http://oglobo.globo.com/brasil/a-historia-de-mora-capitulo-14-estou-cercado-euataco-3671356>. Acesso em: 12 mai. 2015.

MOTA, Carlos Guilherme. Ideologia da cultura brasileira. São Paulo: Ática, 1977.

MUNHOZ, Sara Regina. A atuação do "Centrão" na Assembleia Nacional Constituinte de 1987/1988. Revista Política Hoje, v. 20, n. 1, 2011.

MURARI, Luciana. Natureza e cultura no Brasil (1870-1922). São Paulo: Alameda, 2009.

NAGLE, Jorge. Educação e sociedade na Primeira República. São Paulo: EPU, Rio de Janeiro, Fundação Nacional de Material Escolar, 1976.

NETO, Leonardo Guimarães. Desigualdades e políticas regionais no Brasil. Planejamento e Políticas Públicas, n. 15, jun. 1997. Disponível em: http://www.ipea.gov.br/ppp/index.php/PPP/article/viewFile/123/125. Acesso em: 20 nov. 2014.

NEVES, Lúcia Maria Wanderley. Educação e política no Brasil de hoje. São Paulo: Cortez, 1994.

NEVES, Lúcia Maria Wanderley (coord.). Política educacional nos anos 90: determinantes e propostas. Recife: Editora Universitária da UFPE, 1995.

NOVAIS, Fernando A.; SILVA, Rogério F. da (orgs.). Nova história em perspectiva (vol.1). São Paulo: Cosac Naify, 2011.

OLIVEIRA, Eliézer Rizzo de (org.). Militares: pensamento e ação política. Campinas: Papirus, 1987. . Política educacional: impasses e alternativas. São Paulo: Cortez, 1995.

OLIVEIRA, Eliézer Rizzo de. et al. As Forças Armadas no Brasil. Rio de Janeiro: Espaço e Tempo, 1987a. 
OLIVEIRA, Eliézer Rizzo de (org.). Militares: pensamento e ação política. Campinas: Papirus, 1987b.

OLIVEIRA, Mauro Márcio. Fontes de informações sobre a Assembléia Nacional Constituinte de 1987: quais são, onde buscá-las e como usá-las. Brasília: Senado Federal, 1993.

OLIVEIRA, Romualdo Portela de. Educação e sociedade na Assembleia Constituinte de 1946. Dissertação de Mestrado, Faculdade de Educação/USP, São Paulo, 1990 (2v.) (mimeo.).

. Educação e cidadania: o direito à educação na Constituição de 1988 da República Federativa do Brasil. Tese de Doutorado, Faculdade de Educação/USP, São Paulo, 1995 (mimeo.).

"A Educação na Assembléia Constituinte de 1946". In: A Educação nas Constituintes Brasileiras 1823-1988. Osmar Fávero (org). Editora Autores Associados, 2005.

O'DONNELL, Guillermo; SCHMITTER, Philippe C. Transições do regime autoritário: primeiras conclusões e América Latina. São Paulo: Vértice - Editora Revista dos Tribunais, 1988.

O’DONNELL, Guillermo; SCHMITTER, Philippe C.; WHITEHEAD,Laurence (orgs.). Transições do regime autoritário: sul da Europa. São Paulo: Vértice - Editora Revista dos Tribunais, 1988.

PASSARINHO, Jarbas. "Exposição de Motivos do Senhor Ministro da Educação e Cultura". In: Diário Oficial do Estado de São Paulo, Suplemento especial, 28 de setembro de 1971.

PÉCAUT, Daniel. Os intelectuais e a política no Brasil. São Paulo: Ática, 1990.

PEREIRA, Osny Duarte. Constituinte: anteprojeto da Comissão Afonso Arinos. Brasília: Editora Universidade de Brasília, 1987.

PINHEIRO, Maria Francisca. "O público e o privado na educação: um conflito fora de moda?". In: FÁVERO, Osmar (org.). A educação nas constituintes brasileiras (18231988). Campinas: Autores Associados, 2005.

PINO, Ivany. "A Lei de Diretrizes e Bases da Educação: a ruptura do espaço social e a organização da educação nacional”. In: BRZEZINSKI, Iria (org.). LDB interpretada: diversos olhares se entrecruzam. São Paulo, Cortez: 1997.

PIRES AZANHA, José Mario. Palestra proferida na Escola de Governo. Cadernos de Pesquisa, São Paulo, nº 85, passim.

POCOCK, J.G.A. Linguagens do ideário político. São Paulo: Edusp, 2003. 
PRATT, Mary Louise. Os olhos do império: relatos de viagem e transculturação. São Paulo: Edusc, 1999.

PROJETO NORDESTE; BANCO MUNDIAL; UNICEF. Chamada à ação: combatendo o fracasso escolar no Nordeste: programa de pesquisa e operacionalização de políticas educacionais. Brasília, 1997.

QUARESMA, Silvia Jurema Leone. O Estado e dominação nos pressupostos de Marx, Weber e Durkheim. Revista de Ciência Política, n. 42, 2009. Disponível em: $<$ http://www.achegas.net/numero/42/silvia jurema 42.pdf>. Acesso em $12 / 05 / 2015$.

QUEIROZ, Maria Isaura Pereira. O mandonismo local na vida política brasileira e outros ensaios. São Paulo: Alfa-Omega, 1976.

RAICHELIS, Raquel. Esfera pública e conselhos de assistência social no Brasil. São Paulo: Cortez. 1998.

RAMOS, Augusto Cesar. Competência tributária. 2002. Disponível em: $<$ http://jus.com.br/artigos/2621/competencia-tributaria\#ixzz3|IZqNU2a>. Acesso em: 20 nov. 2014.

"Relatório Meira Mattos mostra situação do ensino universitário". Correio da Manhã, Rio de Janeiro, 25 ago. 1968.

RENAN, Ernest. Que é uma Nação? Plural, Sociologia USP, São Paulo, 1997, p.174 Disponível em: <http://www.revistas.usp.br/plural/article/viewFile/75901/79400> Acesso em: 25 nov. 2014.

RIBEIRO, Sérgio Costa. Educação e cidadania. 1993 (mimeo.).

ROCHA, Antonio Sérgio. Genealogia da Constituinte: do autoritarismo à democratização. Lua Nova, São Paulo, n. 88, 2013.

ROCHA, Maria Selma de Moraes. A evolução dos conceitos da doutrina da Escola Superior de Guerra nos anos 70. Dissertação de Mestrado, FFLCH/USP, São Paulo, 1996.

Fundos públicos e sistemas de ensino na cidade de São Paulo. São Paulo: Instituto Polis / PUC-SP, 2003. (Observatório dos Direitos do Cidadão: acompanhamento e análise das políticas públicas da cidade de São Paulo, 13)

ROCHA, Marlos Bessa Mendes da. "Tradição e modernidade na educação: o processo constituinte de 1933-34". In: FÁVERO, Osmar (org.). A educação nas constituintes brasileiras (1823-1988). Campinas: Autores Associados, 2005.

RODRIGUES, José Honório. Aspirações nacionais. São Paulo: Fulgor, 1965. 
ROMANELLI, Otaíza. História da educação no Brasil (1930-1973). Petrópolis: Vozes, 1982.

ROUQUIÉ, Alain (coord.). Os partidos militares no Brasil. Rio de Janeiro: Record, s/d.

ROUQUIÉ, Alain. O Estado Militar na América Latina. São Paulo: Alfa-Ômega, 1984

ROSANVALLON, Pierre. A Nova Questão Social: repensando o Estado Providência. Brasília: Instituto Teotônio Vilela, 1998.

SAID, Edward W. Cultura e Imperialismo. São Paulo: Companhia das Letras, 2011.

SANTIAGO, Emerson. Common Law. s/d. Disponível em: <http://www.infoescola.com/direito/common-law>. Acesso em: 20 nov. 2012.

SANTOS, Boaventura de Sousa. Modernidade, identidade e a cultura de fronteira. Tempo Social: Revista de Sociologia da USP. São Paulo, v.5, n.1-2, p.31-52, nov. 1994.

SANTOS, Boaventura de Sousa; MENEZES, Maria Paula (orgs.). Epistemologias do Sul. São Paulo: Cortez Editora, 2010.

SARNEY, José. Mensagem no 48, de 1985-CN. Brasília, 28 jun. 1985. Disponível em: http://www.senado.gov.br/publicacoes/anais/constituinte/emenda.pdf. Acesso em 25 nov. 2014.

Palavras do Presidente da República. Diário Oficial da União, Suplemento Especial ao $\mathrm{n}^{\mathrm{0}}$ 185, 26 set. 1986. Disponível em: $<$ http://www.senado.gov.br/publicacoes/anais/constituinte/AfonsoArinos.pdf $>$.

Acesso em: 20 nov. 2014.

SAVIANI, Dermeval. Florestan Fernandes e a educação. Revista Estudos Avançados, São Paulo, IEA/USP, v. 10, n. 26, 1996.

O público e o privado na educação brasileira. Tese de concurso para professor titular. Setor de Estudos: Educação Brasileira - Política Educacional. Universidade Federal do Ceará, Fortaleza, 1992 (mimeo).

Política de municipalização do ensino no Brasil. Tecnologia Educacional. v.22, n.119-120, p. 13-17., jul./out. 1994.

. A nova lei da educação: trajetória, limites e perspectivas. Campinas: Autores Associados, 1997.

SCHERER-WARREN, Ilse; KRISCHKE, Paulo J (orgs.). Novos movimentos sociais: encontros e desencontros com a democracia. São Paulo: Brasiliense, 1987.

SCHWARTZMAN. Simon. Bases do autoritarismo brasileiro. Rio de Janeiro: Campus, 1982. 
SCHULTZ, Theodore W. O valor econômico da educação. Rio de Janeiro: Zahar, 1967.

SENA, Paulo. A União e a aplicação dos recursos vinculados à manutenção e desenvolvimento do ensino. Revista Brasileira de Estudos Pedagógicos, v.83, n.203/204/205, jan.-dez., 2002.

SILVA, Helio. O poder militar. São Paulo: L\&PM, 1987.

SILVA, José Afonso da. "Prefácio". In: LIMA, João Alberto de Oliveira; PASSOS, Edilenice; NICOLA, João Rafael. A gênese do texto da Constituição de 1988. Brasília: Senado Federal, Coordenação de Edições Técnicas, 2013 (2v.)

SKIDMORE, Thomas E. Brasil: de Getulio Vargas a Castello Branco (1930-1964). Rio de Janeiro: Paz e Terra, 1975.

A lenta via brasileira para a democratização: 1974-1985. In: STEPAN, Alfred C. (org.). Democratizando o Brasil. Rio de Janeiro: Paz e Terra, 1988.

1994. . Brasil: de Castelo a Tancredo (1964-1985). São Paulo: Paz e Terra, . Uma história do Brasil. São Paulo: Paz e Terra, 1998.

SOARES, Renato Viana. A educação na Constituição de 1988. Dissertação de Mestrado, Programa de Pós-graduação em Educação, UFES, Vitória, 1990.

- Participação política \& educação: a construção do modelo educacional brasileiro na Constituição de 1988. Vitória: EDUFES, 1999.

SOBOUL, Albert. História da revolução francesa, Zahar Editores, Rio de Janeiro, 1974.

SODRÉ, Nelson W. A história militar do Brasil. Rio de Janeiro: Civilização Brasileira, 1979.

SOUSA JÚNIOR, Luiz de. Educação e política: o projeto de educação do Partido dos Trabalhadores e a Constituinte de 1988. João Pessoa: Editora Universitária, UFPB, 1998.

SOUZA, Maria do Carmo Campello de. A Nova República brasileira: sob a espada de Dâmocles. Stepan, Alfred (org.) Democratizando o Brasil. Rio de Janeiro: Paz e Terra, 1988.

STEPAN, Alfred C. Os militares: da abertura à nova república. Rio de Janeiro: Paz e Terra, 1986.

STEPAN, Alfred C. (org.). Democratizando o Brasil. Rio de Janeiro: Paz e Terra, 1988. 
SUCUPIRA, Newton. "O Ato Adicional de 1934 e a Descentralização da Educação". In: FÁVERO, Osmar (org.). A Educação nas Constituintes Brasileiras 1823-1988. Campinas: Autores Associados, 2005.

TAVARES, Aurélio de Lyra. Segurança nacional: problemas atuais. Rio de Janeiro: José Álvaro Editor, 1964.

TAVARES, Aurélio de Lyra.Brasil de minha geração. Rio de Janeiro: Biblioteca do Exército Editora, 1976/77 Tomos I e II.

TELLES, Vera. "Sociedade civil e a construção de espaços públicos". In: DAGNINO, Evelina (org.) Anos 90: política e sociedade no Brasil. São Paulo: Brasiliense, 1994.

. Pobreza e Cidadania. São Paulo: Editora 34, 2013.

. Direitos Sociais. Belo Horizonte: Editora UFMG, 1996. Disponível em: $<$ http://www.veratelles.net/home/wp-content/uploads/2013/04/1996-Direitossociais.pdf > Acesso em: 25 nov. 2014.

THOMPSON, E. P. Os românticos. Rio de Janeiro: Civilização Brasileira, 2002.

TORRES, Alberto. A organização nacional. São Paulo: Companhia Editora Nacional, 1978.

TREVISAN, Leonardo. O pensamento militar brasileiro. São Paulo: Global, 1985.

TROTSKY, Leon. Aonde vai a França? Brasília: Editora Kiron, 2012.

Bonapartismo, fascismo y guerra. Marxists Internet Archive, mar. 2014. Disponível em: < https://www.marxists.org/espanol/trotsky/1940/agosto/20.htm>. Acesso em: 12/05/2015.

VALDÉS, Jorge Tapia. La doctrina de la seguridade national y el rol politico de las Fuerzas Armadas. Nueva Sociedad,s.1. mar./abr. 1980.

VIANA FILHO, Luís. Governo Castello Branco. Rio de Janeiro: Biblioteca do Exercito, 1975.

VIANNA, Oliveira. Instituições políticas brasileiras. São Paulo: EDUSP, 1987.

VIEIRA, Sofia Lerche. Educação e legislação ordinária: há razões para esperança? Em Aberto, Brasília, ano 7, n.38, pp. 1-12, abr./jun. 1988.

. Em busca de uma $\angle D B$ cidadã. In: $\angle D B$ - Lei de diretrizes e bases

da educação nacional: texto aprovado na Comissão de Educação Nacional, Cultura e Desporto da Câmara dos Deputados.São Paulo: ANDE/Cortez, 1990, p. 95-102.

. Política educacional brasileira na atual conjuntura. XVII Reunião Anual da ANPEd, Caxambu, 23 a 27 de outubro de 1994. 
. Política de municipalização do ensino no Brasil. Tecnologia Educacional, v. 22, n.119-120, pp. 13-17, jul./out. 1994,

. Concepções de qualidade e educação superior. Universa, Brasília, v.3, n.2 (5), out. 1995a.

. "Neoliberalismo, privatização e educação no Brasil". In: Política educacional: impasses e alternativas. São Paulo: Cortez, 1995b.

Política educacional em tempos de transição (1985-1995). Tese para concurso de professor titular em educação, UECE, Fortaleza,1998 (mimeo.).

2003.

. Política Educacional no Brasil: introdução histórica. Brasília: Plano,

WEBER, Max. Textos selecionados. São Paulo: Abril Cultural, 1980.

. Ciência e Política: duas vocações. São Paulo: Martin Claret, 2001.

. La política como profesión. Madrid: Biblioteca Nueva, 2007.

. Economia e sociedade: fundamentos da sociologia compreensiva.

Brasília: Editora UnB, 2012.

WEBER, Silke (org.). Democratização, educação e cidadania:caminho do governo Arraes. 1987-1990. São Paulo: Cortez, 1991.

WEFFORT, Francisco Correia. O populismo na política brasileira. Rio de Janeiro: Paz e Terra, 1980.

WEREBE, Maria José Garcia. 30 anos depois: grandezas e misérias do ensino no Brasil. São Paulo: Ática, 1994. 
ANEXOS 


\section{ANEXO A - MARCOS GERAIS DA ASSEMBLEIA NACIONAL CONSTITUINTE ${ }^{69}$}

\begin{tabular}{|c|c|c|c|c|c|c|c|c|c|}
\hline \multirow[b]{2}{*}{$\begin{array}{l}\text { Fevereiro } \\
\text { de } 1987\end{array}$} & \multirow{2}{*}{$\begin{array}{l}\text { 25/3/1987 } \\
\text { Publicaçăo da } \\
\text { Resolução n } \\
2 / 87 \text { - } \\
\text { Regimento } \\
\text { Interno da } \\
\text { ANC } \\
\text { Março } \\
\text { de } 1987\end{array}$} & \multirow[b]{2}{*}{$\begin{array}{c}\text { Abril } \\
\text { de } 1987\end{array}$} & \multicolumn{2}{|c|}{$\begin{array}{l}\text { 26/6/1987 } \\
\text { Entrega do } \\
\text { anteprojeto de } \\
\text { constituição - } \\
\text { Comissão de } \\
\text { Sistematização } \\
\\
15 / 6 / 1987 \\
\text { Término do } \\
\text { prazo para } \\
\text { encaminhamento } \\
\text { dos anteprojetos } \\
\text { das comissōes } \\
\text { temáticas }\end{array}$} & \multicolumn{2}{|c|}{$\begin{array}{l}\text { 24/11/1987 } \\
\text { Entrega do } \\
\text { Projeto "A" } \\
\\
\text { 18/11/1987 } \\
\text { Término da } \\
\text { votação do } 1^{\circ} \text { e } \\
2^{\circ} \text { substitutivos } \\
\text { da Comissão de } \\
\text { Sistematização }\end{array}$} & \multirow{2}{*}{$\begin{array}{c}5 / 7 / 1988 \\
\text { Entrega do } \\
\text { Projeto "B" } \\
\text { Julho } \\
\text { de } 1988\end{array}$} & \multirow[b]{2}{*}{$\begin{array}{l}\text { Setembro } \\
\text { de } 1988\end{array}$} & \multirow{2}{*}{$\begin{array}{c}\text { 5/10/1988 } \\
\text { Promulgaçăo } \\
\text { Outubro } \\
\text { de } 1988\end{array}$} \\
\hline & & & \multirow[t]{2}{*}{$\begin{array}{c}\text { Junho } \\
\text { de } 1987\end{array}$} & $\begin{array}{l}\text { Julho } \\
\text { de } 1987\end{array}$ & $\begin{array}{l}\text { Novembro } \\
\text { de } 1987\end{array}$ & $\begin{array}{l}\text { Janeiro } \\
\text { de } 1988\end{array}$ & & & \\
\hline $\begin{array}{l}\text { 1/2/1987 } \\
\text { Instalação da } \\
\text { Assembleia } \\
\text { Nacional } \\
\text { Constituinte }\end{array}$ & & $\begin{array}{l}\text { 1/4/1987 } \\
\text { Instalação } \\
\text { das } 8 \\
\text { comissões } \\
\text { temáticas } \\
7 / 4 / 1987 \\
\text { Instalação } \\
\text { das } 24 \\
\text { subcomissões } \\
\text { temáticas } \\
\text { 9/4/1987 } \\
\text { Instalação da } \\
\text { Comissão de } \\
\text { Sistematização }\end{array}$ & & $\begin{array}{l}9 / 7 / 1987 \\
\text { Entrega do } \\
\text { projeto de } \\
\text { constituição } \\
\text { Comissão de } \\
\text { Sistematizaç }\end{array}$ & & $\begin{array}{l}6 / 1 / 198 \\
\text { Publicaş } \\
\text { Resoluç } \\
n^{\circ} 3 / 88 \\
\text { Alteraçã } \\
\text { Regimer } \\
\text { Interno } \\
\text { ANC }\end{array}$ & & $\begin{array}{l}\text { 8/9/1988 } \\
\text { Entrega do } \\
\text { Projeto "C" } \\
\\
\text { 22/9/1988 } \\
\text { Aprovação do } \\
\text { Projeto "D" - } \\
\text { Redação Fina }\end{array}$ & \\
\hline
\end{tabular}

69 Disponível em: <http://www2.camara.leg.br/atividade-legislativa/legislacao/Constituicoes Brasileiras/constituicao-cidada/o-processo-constituinte/linha-do- 
tempo>. Acesso em: 23 nov. 2014. 


\title{
ANEXO B - CARTA DE GOIÂNIA70
}

\section{2 a 5 de setembro de 1986}

\begin{abstract}
A "Carta de Goiânia," aprovada item por item na Sessão de Encerramento, pelos 5 mil educadores presentes, constituía indicação dos educadores brasileiros para a Nova Constituição.
\end{abstract}

Eis a íntegra:

Os educadores presentes em Goiânia na IV Conferência Brasileira de Educação, no período de 2 a 5 de setembro de 1986, vêm a público divulgar as resoluções votadas no encerramento dos trabalhos. Atendendo ao convite das entidades organizadoras - ANDE (Associação Nacional de Educação), ANPEd (Associação Nacional de Pesquisa e PósGraduação em Educação) e CEDES (Centro de Estudos Educação e Sociedade) - seis mil participantes [sic], vindos de todos os Estados do país, debateram temas da problemática educacional brasileira, tendo em vista a indicação de propostas para a nova Carta Constitucional.

Os profissionais da educação declaram-se cientes de suas responsabilidades na construção de uma Nação democrática, onde os cidadãos possam exercer plenamente seus direitos, sem discriminação de qualquer espécie. Estão, por isso, empenhados em debater, analisar e fazer denúncias dos problemas e impasses da educação brasileira, e ao mesmo tempo, em colocar sua capacidade profissional e sua vontade política para a superação dos obstáculos que impedem a universalização do ensino público de qualidade para todo o povo brasileiro.

A IV Conferência Brasileira de Educação, ao propor princípios básicos a serem inscritos na Constituição, tem presente que o país enfrenta graves problemas sociais e econômicos, de natureza estrutural, que entravam a efetiva democratização do conjunto da sociedade. Tem presente, também, que o não enfrentamento urgente de tais problemas acarretará o comprometimento da viabilização das políticas sociais, especialmente da política educacional.

De fato, dados divulgados pelo próprio Governo Federal mostram que cerca de $60 \%$ dos brasileiros encontram-se em estado de extrema pobreza material, em contraste com uma minoria de grupos privilegiados que detêm o usufruto privado da riqueza que é social. Isso significa que as aspirações da coletividade pela democracia econômica, social e política são obstaculizadas por uma organização social injusta e, em decorrência, por políticas governamentais incapazes de promover a justiça social. Persiste uma política econômica, e particularmente salarial, marcada pela distribuição desigual da renda, cujas expressões são

\footnotetext{
${ }^{70}$ ASSOCIAÇÃO NACIONAL DE EDUCAÇÃO; ASSOCIAÇÃO NACIONAL DE PESQUISA E PÓSGRADUAÇÃO EM EDUCAÇÃO; CENTRO DE ESTUDOS EDUCAÇÃO E SOCIEDADE. Carta de Goiânia. In: IV Conferência Brasileira de Educação. Goiânia, 1986. Anais da IV Conferência Brasileira de Educação (t. 2). São Paulo: Cortez, 1988. Disponível em:

$<$ http://www.cedes.unicamp.br/carta goiania.pdf>. Acesso em: 22 nov. 2014.
} 
a questão agrária e a violência social contra os trabalhadores rurais; o enorme endividamento externo; a dívida pública; o precário atendimento às necessidades de escolarização da população e a outras necessidades sociais como saúde, assistência e previdência social.

No âmbito da Educação, o país continua convivendo com problemas crônicos referentes à universalização e qualidade do ensino, à gratuidade escolar, às condições de trabalho do magistério e à escassez e má distribuição das verbas públicas.Não é demais relembrar alguns dados que revelam o estado lastimável em que se encontra a educação nacional:

- mais de $50 \%$ de alunos repetentes ou excluídos ao longo da $1^{\text {a }}$ série do ensino de $1^{\circ} \mathrm{Grau}$;

- cerca de $30 \%$ de crianças e jovens na faixa dos 7 aos 14 anos fora da escola:

- $30 \%$ de analfabetos adultos, e numeroso contingente de jovens e adultos sem acesso à escolarização básica;

- $22 \%$ de professores leigos;

- precária formação e aperfeiçoamento profissional dos professores de todo o país;

- salários aviltados em todos os graus de ensino.

Há dois anos, os participantes da m Conferência Brasileira de Educação aprovavam um Manifesto em que expressavam suas esperanças de que tais problemas crônicos Viessem a ter um encaminhamento mais efetivo. Os educadores envolveram-se num clima de positiva expectativa, que tomava conta da sociedade brasileira face às possibilidades abertas pelas mudanças na vida política do país, uma vez cessado o longo período de regime militar. Havia razões para esperanças: governos estaduais haviam sido eleitos pelo voto popular; profissionais da educação foram chamados a ocupar postos administrativos e técnicos; outras áreas da administração pública passaram a contar com profissionais compromissados com ideais e práticas convergentes com os interesses majoritários da sociedade; algumas reivindicações há anos exigidas pelos educadores (como, por exemplo, a priorização do ensino de $1^{\circ}$ e $2^{\circ}$ Graus) foram anunciadas pelos governos.

Entretanto, passado esse período, os educadores continuam denunciando a incapacidade do sistema político em assegurara concretização de diretrizes educacionais voltadas para o atendimento dos interesses majoritários da população brasileira. Insistindo em práticas políticas arcaicas, os governos federal e estaduais continuam recorrendo a programas de impacto político e de favorecimento a grupos que colocam a educação a serviço de interesses menores. Promoções nacionais como o "Dia D da Educação", Educação Para Todos, Programa Nacional do Livro Didático, Projeto Educar, Projeto Nova Universidade, Projeto das 200 Escolas Técnicas, como também a sucessiva criação das chamadas "comissões de alto nível", não chegam a produzir mais do que efeitos de visibilidade política, já que são medidas descontínuas e desconectadas de um plano global de atendimento ao conjunto dos problemas educacionais. Tais promoções criam uma expectativa ilusória,contribuindo para desviar a atenção dos reais problemas.

Em relação às políticas públicas estaduais, essas mesmas práticas têm sido reiteradas, acrescentando-se que alguns programas de governo pretendem utilizar-seda estrutura e dos recursos do setor educacional para resolver problemas afetos a outros 
setores das políticas públicas, tais como a substituição da educação escolar por meros programas de assistência, saúde e treinamento profissional.

Cabe destacar, ainda, a questão das verbas públicas para a educação, destinadas sobretudo aos projetos de impacto político e não às prioridades efetivas, e frequentemente desviadas para instituições privadas. Esta situação tende a agravar-se com as ações dos grupos privatistas organizados para assegurar seus interesses na Carta Constitucional.

Neste momento em que a Nação seprepara para eleger seus representantes ao Congresso Constituinte, os educadores brasileiros renovam sua disposição de luta, exigindo que os problemas educacionais sejam tratados de maneira responsável e coerente, tendo em vista as reais necessidades e interesses da população.

Os participantes da IV Conferência Brasileira de Educação reivindicam, assim, que a nova Carta Constitucional consagre os princípios de direito de todos os cidadãos brasileiros à educação, em todos os graus de ensino e de dever do Estado em promover os meios para garanti-la. Ao mesmo tempo, se comprometem a lutar pela efetivação destes princípios, organizando-se nas suas entidades, exigindo compromissos dos candidatos às Constituintes a nível federal e estadual e cobrando o cumprimento de medidas propostas para a democratização da educação.

Finalmente, propõem que os princípios formulados a seguir sejam inscritos no texto constitucional:

1 - A educação escolar é um direito de todos os brasileiros e será gratuita e laica nos estabelecimentos públicos, em todos os níveis de ensino.

2 - Todos os brasileiros têm direito à educação pública básica comum, gratuita e de igual qualidade, independentemente de sexo, cor, idade, confissão religiosa e filiação política, assim como da classe social ou da riqueza regional, estadual ou local.

3 - O ensino fundamental com 8 anos de duração é obrigatório para todos os brasileiros, sendo permitida a matrícula a partir dos 6 anos de idade.

4 - O Estado deverá prover os recursos necessários para assegurar as condições objetivas ao cumprimento dessa obrigatoriedade, a ser efetivada com um mínimo de 4 horas por dia, em 5 dias da semana.

5 - É obrigação do Estado oferecer vagas em creches e pré-escolas para crianças de 0 a 6 anos e 11 meses de idade, com caráter prioritariamente pedagógico.

6 - São assegurados aos deficientes físicos, mentais e sensoriais serviços de atendimento pelo Estado, a partir de 0 (zero) ano de idade, em todos os níveis de ensino.

7 - É dever do Estado prover o ensino fundamental, público e gratuito, de igual qualidade, para todos os jovens e adultos que foram excluídos da escola ou a ela não tiveram acesso na idade própria, provendo os recursos necessários ao cumprimento desse dever.

8 - O Estado deverá viabilizar soluções que compatibilizem escolarização obrigatória e necessidade de trabalho do menor até 14 anos de idade e, simultaneamente, captar e concentrar recursos orçamentários para a criação de um Fundo de Bolsas de Estudo a ser destinado às crianças e adolescentes de famílias de baixa renda, matriculados na escola pública. 
9 - O Ensino de $2^{\circ}$ grau, com 3 anos de duração, constitui a segunda etapa do ensino básico e é direito de todos.

10 - O ensino, em qualquer nível, será obrigatoriamente ministrado em língua portuguesa, sendo assegurado aos indígenas o direito à alfabetização nas línguas materna e portuguesa.

11 - Será definida uma carreira nacional do magistério, abrangendo todos os níveis e que inclua o acesso com o provimento de cargos por concurso, salário digno e condições satisfatórias de trabalho, aposentadoria com proventos integrais aos 25 anos de serviço no magistério e direito à sindicalização.

12 - As universidades e demais instituições de ensino superior terão funcionamento autônomo e democrático.

13 - As universidades públicas devem ser parte integrante do processo de elaboração da política de cultura, ciência e tecnologia do País, e agentes primordiais na execução dessa política que será decidida, por sua vez, no âmbito do Poder Legislativo.

14 - A lei regulamentará a responsabilidade dos Estados e Municípios na administração de seus sistemas de ensino e a participação da União para assegurar um padrão básico comum de qualidade dos estabelecimentos educacionais.

15 - Os recursos públicos destinados à educação serão aplicados exclusivamente nos sistemas de ensino criados e mantidos pela União, Estados e Municípios.

16 - Será de responsabilidade exclusiva dos setores da saúde pública a atenção à saúde da criança em idade escolar.

17 - A merenda escolar e qualquer outro programa assistencial a ser desenvolvido nas escolas devem contar com verbas próprias, desvinculadas, dos recursos orçamentários para a educação "stricto sensu", porém gerenciadas por órgãos da área educacional.

18 - E permitida a existência de estabelecimentos de ensino privado, desde que atendam às exigências legais e não necessitem de recursos públicos para sua manutenção.

19 - O Estado deverá garantir à sociedade civil o controle da execução da política educacional em todos os níveis(federal, estadual e municipal), através de organismos colegiados, democraticamente constituídos.

20 - O Estado assegurará formas democráticas de participação e mecanismos que garantam o cumprimento e o controle social efetivo das suas obrigações referentes à educação pública, gratuita e de boa qualidade em todos os níveis de ensino.

21 - Fica mantido o disposto pela Emenda Calmon (24, § 4ํㅡ do art. 176 da atual Constituição), assim como pelas Emendas Passos Porto (EC 23) Irajá Rodrigues (EC 27) e a lei estabelecerá sanções jurídicas e administrativas no caso do não - cumprimento destes dispositivos.

Consideram, outrossim, essencial sua participação, através das entidades de representação na área, tanto na elaboração da Constituição, quanto da lei acima referida.

Os educadores presentes à IV Conferência Brasileira de Educação consideram indispensável que seja elaborada uma nova lei de diretrizes e bases da educação nacional, a partir dos princípios inscritos na Constituição. 
Consideram, ainda, que devem ser mobilizados todos os recursos no sentido de tomar público este posicionamento e de conclamar os candidatos dos diversos partidos à Constituinte, para a defesa dos princípios aqui enunciados.

Goiânia, 5 de setembro de 1986. 


\title{
ANEXO C - MANIFESTO EM DEFESA DA ESCOLA PUBLICA E GRATUITA71
}

\author{
Fórum da Educação na Constituinte Defesa do Ensino Público e Gratuito
}

Lutamos por uma educação pública, gratuita, critica, laica, democrática e de qualidade. Se esta é uma luta já antiga, hoje mais do que nunca ela é necessária. É uma luta pela transformação da educação que temos.

Os problemas centrais da educação no Brasil são o descompromisso do poder público com a educação e a privatização do ensino, resultando no baixíssimo nível de escolaridade da população. Fugindo à sua responsabilidade social com o ensino e a produção do saber, o governo desenvolve uma política educacional que favorece o empresariamento do ensino, tratado como mercadoria.

Oito milhões de crianças em idade escolar estão fora do sistema educacional. Trinta milhões de brasileiros são analfabetos. São poucos os filhos de trabalhadores que continuam seus estudos além de algumas séries iniciais. O descaso com a educação e o desvio de recursos governamentais para os estabelecimentos particulares vêm prejudicando a qualidade do ensino público, que continua apresentando carências crônicas e dramáticas. Apesar das conquistas dos trabalhadores da educação, seus salários continuam aviltados e as condições de trabalho permanecem precárias.

Defendemos a escola pública e gratuita porque a educação é um direito de todo cidadão. Esta luta passa hoje, principalmente, pela exigência de uma efetiva política de ampliação e fortalecimento de toda a rede oficial de $1^{\circ}$ e $2^{\circ}$ graus, faculdades $e$ universidades. Os princípios desta política devem estar expressos na Constituição.

Vivemos um momento crucial para a construção da democracia em nosso país. A Constituição que queremos não pode ter como marca fundamental o descompromisso com a maioria da sociedade, com seus anseios de justiça e com suas legitimas aspirações de igualdade e de respeito aos direitos individuais e sociais.

Hoje o Congresso Constituinte, apesar das limitações a que está submetido pela vigência da legislação da ditadura militar, inclusive a lei da greve e de segurança nacional, e pelo abuso do poder econômico no processo eleitoral, é, contudo, um importante espaço de luta e conquista social.

Queremos uma educação para todos os brasileiros e marcada pela significativa ampliação do espaço democrático. É preciso reverter a saída prematura de tantos alunos do sistema educacional, oferecendo condições para que nele permaneçam por mais tempo e com maior proveito. É preciso que a escola tenha uma gestão democrática. É preciso que a universidade tenha plenamente garantida sua autonomia pedagógica, cientifica e administrativa.

A educação pela qual lutamos conjuga saber crítico e compromisso com a realidade social e sua transformação. O ensino em todos os níveis deve voltar-se para 0 desenvolvimento da capacidade de pensar, julgar e agir.

Só a escola pública, gratuita, democrática e de boa qualidade pode cumprir este papel para o conjunto da população.

Só a universidade pública, gratuita, autônoma, democrática e competente pode cumprir seu papel de agente da soberania cultural, científica, artística e tecnológica do país.

\footnotetext{
71 Ata da 48aㅗ Sessão, 9 de abril de 1987. Diário da Assembléia Nacional Constituinte, ano I, n. 43. Brasília: Senado Federal, 10 abr. 1987, p. 192-3. Disponível em: $<$ http://www2.camara.leg.br/atividade-legislativa/legislacao/Constituicoes Brasileiras/constituicaocidada/publicacoes/anais-da-assembleia-nacional-constituinte>. Acesso em: 22 nov. 2014.
} 
Neste momento arregimentam-se as forças privativas, interessadas em se apropriar de mais verbas públicas do ensino para servir grupos minoritários da população.É chegada a hora de uma grande Campanha Nacional em Defesa da Escola Pública e Gratuita para todos. No interesse da maioria a Constituinte precisa garantir os seguintes princípios básicos:

1. A educação é direito de todo cidadão, sendo dever do Estado oferecer ensino público, gratuito e laico para todos, em todos os níveis;

2. Governo federal destinará nunca menos de 13\%, e os governos dos Estados, do Distrito Federal e dos Municípios aplicarão, no mínimo, 25\% de sua receita tributária na manutenção e desenvolvimento do ensino púbico e gratuito;

3. As verbas públicas destinam-se exclusivamente às escolas públicas, criadas e mantidas pelo governo Federal, pelos Estados, Distrito Federal e Municípios;

4. A democratização da escola em todos os níveis deve ser assegurada quanto ao acesso, permanência e gestão.

Conclamamos todos os brasileiros a se manifestarem publicamente na defesa destes princípios para garantir sua aprovação na Constituinte. Vamos organizar uma ampla e massiva Campanha em Defesa da Escola Pública e Gratuita!

([14] Entidades que Subscrevem)

- Associação Nacional de Educação - ANDE

- Associação Nacional de Docentes de Ensino Superior - ANDES

- Associação Nacional de Profissionais de Administração da Educação - ANPAE

- Associação Nacional de Pesquisa e Pós-Graduação em Educação - ANPEd

- Confederação dos Professores do Brasil - CPB

- Centro de Estudos Educação e Sociedade - CEDES

- Central Geral dos Trabalhadores - CGT

- Central Única dos Trabalhadores - CUT

- Federação das Associações dos Servidores das Universidades Brasileiras FASUBRA

- Ordem dos Advogados do Brasil - OAB

- Sociedade Brasileira para o Progresso da Ciência - SBPC

- Sociedade de Estudos e Atividades Filosóficos - SEAF

- União Brasileira dos Estudantes Secundaristas - UBES

- União Nacional dos Estudantes - UNE 


\section{ANEXO D - PROPOSTA EDUCACIONAL PARA A CONSTITUIÇÃO ${ }^{72}$}

Fórum da Educação na Constituinte em Defesa do Ensino Público e Gratuito

Art. 1ํ- A educação, baseada nos princípios de democracia, da liberdade de expressão, da soberania nacional e do respeito aos direitos humanos é um dos agentes do desenvolvimento da capacidade de elaboração e reflexão crítica da realidade, visando a preparação para o trabalho e a sustentação da vida.

Art. $2^{\circ}$ - O ensino público, gratuito e laico em todos os níveis de escolaridade é direito de todos os cidadãos brasileiros, sem distinção de sexo, raça, idade, confissão religiosa, filiação política ou classe social.

Parágrafo único. É dever do Estado o provimento em todo o território nacional de vagas em número suficiente para atender à demanda.

Art. $3^{\circ}$ - É livre a manifestação pública de pensamento e de informação. Sobre o ensino e a produção do saber não incidirão quaisquer imposição ou restrições de natureza filosófica, ideológica, religiosa ou política.

Parágrafo único. É proibida toda e qualquer forma de censura.

Art. 4ํ - O ensino de primeiro grau, com oito anos de duração, é obrigatório para todas as crianças a partir de sete anos de idade, visando propiciar formação básica comum indispensável a todos.

$\S 1^{\circ}$ - Cabe aos Poderes Públicos a chamada à escola até, no mínimo, 14 anos.

$\S 2^{\circ}$ - É permitida a matrícula no primeiro grau a partir de seis anos de idade.

$\S 3^{\circ}$ - O ensino de primeiro grau público e gratuito será também garantido aos jovens e adultos que na idade própria a ele não tiveram acesso.

$\S$ 4ํ - A União assegurará, supletivamente, aos Estados, ao Distrito Federal e aos Municípios os meios necessários ao cumprimento da obrigatoriedade escolar na forma do caput deste Artigo.

Art. $5^{\circ}$ - O ensino de segundo grau constitui a segunda etapa do ensino básico e é direito de todos. Visa assegurar formação humanística, científica e tecnológica voltada para o desenvolvimento de uma consciência crítica em todas as modalidades de ensino em que se apresentar.

No segundo grau serão oferecidos cursos de:

I - formação geral;

II - caráter profissionalizante, em que a formação geral seja Articulada com formação técnica de qualidade e;

III - formação de professores para as séries iniciais do $1^{\circ}$ grau e da pré-escola.

Art. 6ำ - As instituições de ensino e pesquisa brasileira devem ter garantido um padrão de qualidade indispensável para que sejam capazes de cumprir seu papel de agente da soberania cultural, científica, artística e tecnológica do País, contribuindo para a melhoria das condições de vida, trabalho e participação da população brasileira.

$\S 1^{\circ}$ As Instituições de Ensino Superior terão plenamente garantia e sua autonomia pedagógica, científica, administrativa e financeira.

\footnotetext{
72 BRASIL. Assembleia Nacional Constituinte. Atas da Subcomissão de Educação Cultura e Esportes. Anais da Assembleia Nacional Constituinte 1987-1988. Brasília, 1988b Disponível em: $<$ http://www2.camara.leg.br/atividade-legislativa/legislacao/Constituicoes Brasileiras/constituicaocidada/publicacoes/anais-da-assembleia-nacional-constituinte>. Acessado em: 05 jul. 2014, p. 243-4.
} 
$\S 2^{\circ}$ As Instituições de Ensino Superior brasileiras serão necessariamente orientadas pelo princípio da indissociabilidade do ensino, da pesquisa e da extensão.

Art. $7^{0}$ - A formação mediante estágios deverá propiciar condições da aprendizagem condignas e compatíveis com cada área de especialização, na forma da lei.

Art. 8o - O Estado garantirá a todos o direito ao ensino público e gratuito através de programas sociais, devidamente orçamentados no seu setor específico, tais como:

I - transporte, alimentação, material escolar e serviço médico-odontológico nas creches, pré-escolas e escoas de $1^{\circ}$ grau;

II - bolsas de estudo a estudantes matriculados na rede oficial pública, quando a simples gratuidade não permitir que continuem seu aprendizado.

Art. 9ำ Inclui-se na responsabilidade do Estado, na forma do art. 1을

I - a oferta de creches para crianças de zero a três anos e ensino pré-escolar dos quatro aos seis anos;

II - a garantia de educação especializada para os portadores de deficiências físicas, mentais e sensoriais em qualquer idade.

Art. $10^{\circ}$ - O ensino, em qualquer nível,será obrigatoriamente ministrado na língua portuguesa, sendo assegurado aos indígenas o ensino em sua língua nativa.

Art. $11^{\circ}$ - Anualmente a União aplicará nunca menos de $13 \%$, e os Estados, o Distrito Federal e os Municípios $25 \%$ no mínimo, da Receita Tributária, exclusivamente na manutenção e desenvolvimento dos sistemas oficiais de ensino, na forma da lei.

$\S 1$ 10 Para fins desse artigo excluem-se as escolas de treinamento destinados a fins específicos e subordinados a Ministérios, Secretarias e empresas públicas, que não o Ministério da Educação.

$\S 2^{\circ}$ É vedada a transferência de recursos públicos a estabelecimentos educacionais que não integrem os sistemas oficiais de ensino.

Art. $12^{\circ}$ - Serão criados mecanismos de controle democrático da arrecadação e utilização dos recursos destinados à educação, assegurada a participação de estudantes, professores, funcionários, pais de alunos e representantes da comunidade científica e entidades da classe trabalhadora.

Art. 13ำ - As empresas comerciais, industriais e agrícolas são obrigadas a recolher a contribuição do salário-educação, na forma da lei.

Parágrafo único. Os recursos do salário-educação destinam-se exclusivamente ao desenvolvimento do ensino público oficial de $1^{\circ}$ grau, vedado seu emprego para qualquer outro fim.

Art. 14ำ - Anualmente a União aplicará nunca, menos de $2 \%$ do valor do Produto Interno Bruto em atividades de pesquisa científica e tecnológica desenvolvida no País.

Art. 15ำ - O Estado autorizará a existência de escolas particulares, desde que não recebem verbas públicas, que estejam segundo padrões de qualidade e que sejam subordinadas às normas ordenadoras da educação nacional.

$\S 1$ 1 A existência de escolas privadas estará condicionada à observância daquelas normas, à garantia aos professores e funcionários da estabilidade no emprego, de remuneração adequada, de carreira docente e técnico-funcional e da participação de alunos, professores e funcionários nos organismos de deliberação da instituição, bem como a garantia de que a instituição sustentará econômica e financeiramente o funcionamento da escola. 
$\S 2^{2}$ Cabe aos Poderes Públicos assegurar, através da fiscalização, a observância permanente dessas normas e condições, sob pena de suspensão da autorização para o funcionamento, sem prejuízo das sanções cabíveis, na forma da lei.

$\S 3^{\circ}$ Os estabelecimentos de ensino privado, em funcionamento na data da promulgação deste ato, deverão ajustar-se aos dispositivos legais ou terão sua autorização de funcionamento suspensa, na forma da lei.

Art. $16^{\circ}$ - Compete à União elaborar o Plano Nacional de Educação, prevendo a participação dos Estados, Distrito Federal e Municípios.

Art. 17ํㅡ - A lei regulamentará a responsabilidade dos Estados e Municípios na administração de seus sistemas de ensino e a participação da União com vistas a assegurar padrões de qualidade, na forma do art. $1 \stackrel{\circ}{\circ}$.

Art. 18ำ - A lei regulamentará a participação da comunidade escolar (professoras, estudantes, funcionários e pais), da comunidade científica e das entidades representativas da classe trabalhadora em organismos democraticamente constituídos para a definição e o controle da execução da política educacional em todos os níveis (federal, estadual e municipal).

Art. 19ำ - A gestão acadêmica, científica, administrativa e financeira de todas as instituições de ensino de todos os níveis e das instituições de pesquisa, além de todos os organismos públicos de financiamento de atividade de pesquisa, extensão,aperfeiçoamento de pessoal docente e desenvolvimento científico e tecnológico deverá ser democrática, conforme critérios públicos e transparentes.

$\S 1^{\circ}$ - As funções de direção e coordenação nas instituições de ensino em todos os níveis e nas instituições de pesquisa serão preenchidas através de eleições pela comunidade da instituição respectiva, sendo garantida a participação de todos os segmentos dessa comunidade.

$\S 2^{0}$ - A produção, a seleção, a edição e a distribuição de material didático sob a responsabilidade do poder público devem ser submetidas ao controle social e democrático da comunidade, garantindo-se a representatividade dos diferentes pontos de vista, respeitadas as especificidades regionais e culturais.

Art. $20^{\circ}$ - As normas de funcionamento e supervisão do ensino, fixadas em lei, visarão assegurar padrões de qualidade, na forma do art. $1^{\circ}$.

Art. 21 - A lei estabelecerá nível nacional, princípios básicos das carreiras do magistério público para os diferentes níveis de ensino, assegurando:

I - provimento de cargos e funções mediante concurso público de títulos e provas;

II - salário e condições dignas de trabalho e aperfeiçoamento profissional;

III - estabilidade de emprego, seja qual for o regime jurídico;

IV - aposentadoria com proventos integrais aos 25 anos de serviço:

V - direito irrestrito à sindicalização; e

VI - condições para a elaboração e aplicação do estatuto do magistério municipal em todos os municípios que dispuserem de rede própria de ensino. Os municípios que não cumprirem o estabelecido serão punidos na forma da lei.

\section{Do Sistema Tributário, do Orçamento e das Finanças}

Art. 1 - Integram a Receita de Impostos dos Estados, Distrito Federal e Municípios os tributos diretamente arrecadados, bem como aqueles que Ihes forem transferidos nos termos da lei. 
Art. $2^{\circ}$ - Os estabelecimentos privados de ensino não serão beneficiados por isenção fiscal de qualquer natureza, ficando sujeitos aos mesmos impostos que incidam sobre as atividades das demais empresas privadas.

Art. 3o - Os valores das receitas e das despesas dos Poderes Constituídos das esferas federal, estadual e municipal serão de domínio público no que respeita às suas diversas origens e finalidade, modos de arrecadação e formas de emprego.

\section{Da Legislação Complementar}

Art. 1 - A legislação complementar estabelecerá sanções para os casos de violação dos mandamentos Constitucionais. 
ANEXO E - CRONOLOGIA GERAL DA ASSEMBLEIA NACIONAL CONSTITUINTE $\left(1987\right.$ - 1988 ${ }^{73}$

\begin{tabular}{|c|c|c|}
\hline MOMENTOS & ETAPAS (7) & FASES \\
\hline $\begin{array}{c}1987 \\
1 \text { fev. a } \\
31 \text { mar. }^{74}\end{array}$ & Preliminar & $\begin{array}{l}\text { Definição do Regimento Interno da ANC } \\
\text { Sugestões: Cidadãos, Constituintes e Entidades }\end{array}$ \\
\hline \multirow{2}{*}{$\begin{array}{l}1{ }^{\circ} \text { abr. a } \\
15 \text { jun. }\end{array}$} & Subcomissões Temáticas (24) & $\begin{array}{l}\text { A: Anteprojeto do Relator } \\
\text { B: Emenda ao Anteprojeto do Relator } \\
\text { C: Anteprojeto da Subcomissão } \\
\text { D: NÃO HÁ FASE D }\end{array}$ \\
\hline & Comissões Temáticas (8) & $\begin{array}{l}\text { E: Emenda ao Anteprojeto da Subcomissão na Comissão } \\
\text { F: Substitutivo do Relator } \\
\text { G: Emenda ao Substitutivo } \\
\text { H: Anteprojeto da Comissão }\end{array}$ \\
\hline $\begin{array}{c}9 \text { abr. a } \\
24 \text { nov. }{ }^{75}\end{array}$ & Comissão de Sistematização & $\begin{array}{l}\text { I: Anteprojeto de Constituição } \\
\text { J/K: Emendas de Mérito e de Adequação ao Anteprojeto } \\
\text { L: Projeto de Constituição } \\
\text { M: Emendas (1P) de Plenário e Populares } \\
\text { N: Substitutivo } 1 \text { do Relator } \\
\text { O: Emenda (ES) ao Substitutivo } 1 \\
\text { P: Substitutivo } 2 \text { do Relator }\end{array}$ \\
\hline $\begin{array}{l}1988 \\
7 \text { jan. a } \\
2 \text { set. }\end{array}$ & Plenário & $\begin{array}{l}\text { Q: Projeto A (início } 1^{\circ} \text { turno) } \\
\text { R: Ato das Disposições Transitórias } \\
\text { S: Emenda (2P) de Plenário e Emendas do Centrão } \\
\text { T: Projeto B (fim do } 1^{\circ} \text {; início } 2^{\circ} \text { turno) } \\
\text { U: Emenda }(2 \mathrm{~T}) \text { ao Projeto } \mathrm{B} \\
\text { V: Projeto } C \text { (fim } 2^{\circ} \text { turno) }\end{array}$ \\
\hline $\begin{array}{l}21 \text { abr. a } \\
22 \text { set. }\end{array}$ & Comissão de Redação & $\begin{array}{l}\text { W: Proposta exclusivamente de redação } \\
\text { X: Projeto D - redação final }\end{array}$ \\
\hline 5 out. & Epílogo & Y: Promulgação \\
\hline
\end{tabular}

73 Elaborada a partir de quadros disponíveis em: <http://www2.camara.leg.br/atividade-legislativa/legislacao/Constituicoes Brasileiras/constituicao-cidada/oprocesso-constituinte> e <http://www.senado.gov.br/publicacoes/GeneseConstituicao/pdf/encarte painel2.pdf>. Acesso em 22 nov. 2014.

74 De 9 fevereiro a 31 de março de 1987: Regimento Interno e eleição da Mesa.

75 De 10 de novembro a 5 de janeiro de 1988: reforma do Regimento Interno. 


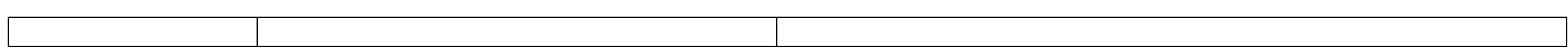




\section{ANEXO F - COMISSÕES E SUBCOMISSÕES TEMÁTICAS ${ }^{76}$}

Assembleia Nacional Constituinte

\begin{tabular}{|c|c|}
\hline COMISSÕES (8) & SUBCOMISSÕES (24) \\
\hline $\begin{array}{l}\text { I. Comissão da Soberania e } \\
\text { dos Direitos e Garantias do } \\
\text { Homem e da Mulher }\end{array}$ & $\begin{array}{l}\text { Nacionalidade, da Soberania e das } \\
\text { Relações Internacionais (A) } \\
\text { - } \begin{array}{l}\text { Direitos Políticos, dos Direitos Coletivos e } \\
\text { das Garantias (B) }\end{array} \\
\text { - } \quad \text { Direitos e Garantias Individuais (C) }\end{array}$ \\
\hline $\begin{array}{l}\text { II. Comissão da Organização } \\
\text { do Estado }\end{array}$ & $\begin{array}{l}\text { - União, Distrito Federal e Territórios (A) } \\
\text { - } \quad \text { Estados (B) } \\
\text { - Municípios e Regiões (C) }\end{array}$ \\
\hline $\begin{array}{l}\text { III. Comissão da Organização } \\
\text { dos Poderes e Sistema de } \\
\text { Governo }\end{array}$ & $\begin{array}{l}\text { - } \quad \text { Poder Legislativo }(\mathrm{A}) \\
\text { - } \quad \text { Poder Executivo }(\mathrm{B}) \\
\text { - }\end{array}$ \\
\hline $\begin{array}{l}\text { IV. Comissão da Organização } \\
\text { Eleitoral, Partidária e } \\
\text { Garantia das Instituições }\end{array}$ & $\begin{array}{l}\text { - Sistema Eleitoral e Partidos Políticos (A) } \\
\text { - Sefesa do Estado, da Sociedade e de sua } \\
\text { - Garantia da Constituição, Reformas e } \\
\text { Emendas (C) }\end{array}$ \\
\hline $\begin{array}{l}\text { V. Comissão do Sistema } \\
\text { Tributário, Orçamento e } \\
\text { Finanças }\end{array}$ & $\begin{array}{ll}\text { - } & \text { Tributos, Participação e Distribuição das } \\
& \text { Receitas }(A) \\
\text { - Orçamento e Fiscalização Financeira (B) } \\
\text { - } \quad \text { Sistema Financeiro (C) }\end{array}$ \\
\hline $\begin{array}{l}\text { VI. Comissão da Ordem } \\
\text { Econômica }\end{array}$ & $\begin{array}{l}\text { - Princípios Gerais, Intervenção do Estado, } \\
\text { Regime da Propriedade do Subsolo e da } \\
\text { Atividade Econômica (A) } \\
\text { - } \text { Questão Urbana e Transporte (B) } \\
\text { Política Agrícola e Fundiária e da Reforma } \\
\text { Agrária (C) }\end{array}$ \\
\hline VII. Comissão da Ordem Social & 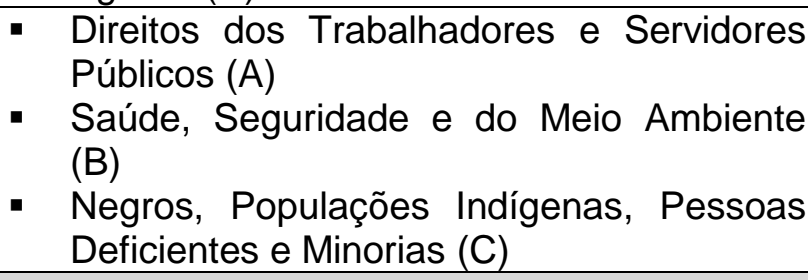 \\
\hline $\begin{array}{l}\text { VIII. Comissão da } \\
\text { Família, da Educação, } \\
\text { Cultura e Esportes, da } \\
\text { Ciência e Tecnologia e da } \\
\text { Comunicação }\end{array}$ & $\begin{array}{l}\text { - Educação, Cultura e Esportes (A) } \\
\text { - Ciência e Tecnologia e da Comunicação } \\
\text { (B) } \\
\text { - Família, do Menor e do Idoso (C) }\end{array}$ \\
\hline
\end{tabular}

76 "As discussões do novo texto constitucional na Assembleia Nacional Constituinte tiveram início nas 24 Subcomissões Temáticas, agrupadas em 8 Comissões Temáticas. Após aprovado na Subcomissão, o texto seguiu para a Comissão Temática respectiva, onde foram elaborados os capítulos por temas. Os três anteprojetos de cada Subcomissão foram reunidos em um anteprojeto único e, em seguida, transformado em um Anteprojeto de Comissão [...]". Disponível em: $<$ http://www2.camara.leg.br/atividade-legislativa/legislacao/Constituicoes Brasileiras/constituicaocidada/o-processo-constituinte/lista-de-comissoes-e-subcomissoes>. Acesso em: 23 nov. 2014. 


\section{ANEXO G - CONSTITUINTES MEMBROS DA COMISSÃO VIII 77}

Assembleia Nacional Constituinte

Comissão VIII - da Família, da Educação, Cultura e Esportes, da Ciência e Tecnologia e da Comunicação

Presidente: Marcondes Gadelha (PFL-PB)

$1^{\circ}$ Vice-Presidente: José Elias Moreira (PTB-MS)

$2^{\circ}$ Vice-Presidente: Osvaldo Sobrinho (PMDB-MS)

Relator: Artur da Távola (PMDB-RJ)

\begin{tabular}{|l|l|}
\hline \multicolumn{1}{|c|}{ TITULARES } & \multicolumn{1}{|c|}{ PMDPLENTES } \\
\hline 1. João Calmon; & Almir Gabriel; \\
2. Louremberg Nunes Rocha; & Irapuã Costa Júnior; \\
3. Pompeu de Souza; & Luiz Viana; \\
4. Aloísio Vasconcelos; & Nelson Carneiro; \\
5. Antônio de Jesus; & Ronan Tito; \\
6. Antonio Gaspar; & Acival Gomes; \\
7. Artur da Távola; & Antônio Brito; \\
8. Bezerra de Mello; & Antônio Câmara; \\
9. Caio Pompeu; & Carlos Benevides; \\
10. Cássio Cunha Lima; & Carlos Cotta; \\
11. Cristina Tavares; & Célio de Castro; \\
12. Eliel Rodrigues; & Domingo Juvenil; \\
13. Ervin Bonkoski; & Eduardo Moreira; \\
14. Fernando Cunha; & Expedito Júnior; \\
15. Flavio Palmier da Veiga; & Felipe Cheidde; \\
16. França Teixeira; & Francisco Sales; \\
17. Hermes Zaneti; & Gabriel Guerreiro; \\
18. Joaci Góis; & Hélio Costa; \\
19. José Carlos Martinez; & Ivo Lech; \\
20. Koyulha; & João Herrmann Neto; \\
21. Márcia Kubitschek; & Jorge Hage; \\
22. Maria Lúcia; & José Carlos Sabóia; \\
23. Matheus lesen; & José Dutra; \\
24. Mendes Ribeiro; & Jovanni Masini; \\
25. Nelson Aguiar; & Leopoldo Bessone; \\
26. Octávio Elísio; & Mário Bochardet; \\
27. Onofre Corrêa; & Mário de Oliveira; \\
28. Osvaldo Sobrinho; & Maurício Nasser; \\
29. Paulo Silva; & Messias Soares; \\
30. Rita Camata; & Renato Bernardi; \\
31. Roberto Vital; & Renato Johnsson; \\
32. Tadeu França; & Rodrigues Palma; \\
33. Ubiratan Aguiar; & Samir Achôa; \\
34. Vingt Rosado. & Santinho Furtado. \\
\hline & \\
\hline
\end{tabular}

77 Elaborado a partir de lista disponível em: < http://www2.camara.leg.br/atividadelegislativa/legislacao/Constituicoes Brasileiras/constituicao-cidada/o-processoconstituinte/comissoes-e-subcomissoes/comissa08/comissa08 >. Acesso em: 23 nov. 2014. 


\begin{tabular}{|c|c|}
\hline $\begin{array}{l}\text { 1. Agripino Lima; } \\
\text { 2. Ângelo Magalhães; } \\
\text { 3. Arolde de Oliveira; } \\
\text { 4. Átila Lira; } \\
\text { 5. Claúdio Âvila; } \\
\text { 6. Eraldo Tinoco; } \\
\text { 7. Eunice Michiles; } \\
\text { 8. Fausto Rocha; } \\
\text { 9. Iberê Ferreira; } \\
\text { 10. Dionísio Hage; } \\
\text { 11. José Moura; } \\
\text { 12. José Queiroz; } \\
\text { 13. Marcondes Gadelha; } \\
\text { 14. Paulo Marques; } \\
\text { 15. Pedro Canêdo; } \\
\text { 16. Rita Furtado. }\end{array}$ & $\begin{array}{l}\text { Antonio Ueno; } \\
\text { Eraldo Trindade; } \\
\text { Evaldo Gonçalves; } \\
\text { Ézio Ferreira; } \\
\text { Francisco Coelho; } \\
\text { Geovani Borges; } \\
\text { José Lins; } \\
\text { Luiz Eduardo; } \\
\text { Pedro Ceolin; } \\
\text { Sadie Hauache; } \\
\text { Sandra Cavalcanti; } \\
\text { Orlando Pacheco; } \\
\text { Osvaldo Coelho; } \\
\text { Jose Jorge; } \\
\text { Vago. }\end{array}$ \\
\hline \multicolumn{2}{|l|}{ - } \\
\hline $\begin{array}{l}\text { 1. Aécio Borba; } \\
\text { 2. Antônio Salim Curiati; } \\
\text { 3. Arnolde Fioravante; } \\
\text { 4. Francisco Diógenes. }\end{array}$ & $\begin{array}{l}\text { Melo Reis; } \\
\text { Ruberval Pilloto; } \\
\text { Vieira da Silva; } \\
\text { Wilma Maia. }\end{array}$ \\
\hline \multicolumn{2}{|c|}{ PDT } \\
\hline $\begin{array}{l}\text { 1. Carlos Alberto Caó; } \\
\text { 2. Chico Humberto; } \\
\text { 3. João de Deus Antunes. }\end{array}$ & $\begin{array}{l}\text { Juarez Antunes; } \\
\text { Roberto D'Ávila; } \\
\text { Vago. }\end{array}$ \\
\hline \multicolumn{2}{|c|}{ PTB } \\
\hline $\begin{array}{l}\text { 1. José Elias Moreira; } \\
\text { 2. Roberto Augusto Lopes; } \\
\text { 3. Sólon Borges dos Reis. }\end{array}$ & $\begin{array}{l}\text { José Elias Murad; } \\
\text { Fábio Raunheitti; } \\
\text { Gastone Righi. }\end{array}$ \\
\hline \multicolumn{2}{|l|}{ s. sutumi dourges uus nels. } \\
\hline $\begin{array}{l}\text { 1. Florestan Fernandes; } \\
\text { 2. Olívio Dutra. }\end{array}$ & $\begin{array}{l}\text { Gumercindo Milhomen; } \\
\text { Paulo Delgado. }\end{array}$ \\
\hline \multicolumn{2}{|r|}{ PL } \\
\hline 1. Álvaro Valle. & José Carlos Coutinho. \\
\hline \multicolumn{2}{|c|}{ PDC } \\
\hline 1. Sotero Cunha. & Vago. \\
\hline \multicolumn{2}{|c|}{ PC do B } \\
\hline Vago. & Eduardo Bonfim. \\
\hline
\end{tabular}




\section{ANEXO H - CRONOLOGIA DE REUNIÕES DA COMISSÃO VIII 78}

\begin{tabular}{|c|c|c|c|}
\hline Reunião & Data & Objeto & Diário da ANC \\
\hline $1^{a}$ & $1 / 4 / 1987$ & $\begin{array}{l}\text { Instalação e eleição do Presidente e Vice- } \\
\text { Presidentes }\end{array}$ & $\frac{1 / 5 / 1987}{\text { Supl. } 53 \text { p. } 189}$ \\
\hline $2^{\mathrm{a}}$ & $25 / 5 / 1987$ & $\begin{array}{l}\text { Recebimento dos Anteprojetos das Subcomissões: } \\
\text { da Ciência e Tecnologia e da Comunicação; e da } \\
\text { Família, Menor e Idoso. Discussão do Regimento } \\
\text { Interno }\end{array}$ & $\frac{8 / 7 / 1987}{\text { Supl. } 90 \text { p. } 161}$ \\
\hline $3^{\underline{a}}$ & $26 / 5 / 1987$ & $\begin{array}{l}\text { Leitura do recurso encaminhado à Comissão sobre o } \\
\text { Anteprojeto da Subcomissão da Ciência e } \\
\text { Tecnologia e da Comunicação. Discussão e votação } \\
\text { do Regimento Interno da Comissão }\end{array}$ & Supl. 90 p. 166 \\
\hline $4^{\mathrm{a}}$ & $27 / 5 / 1987$ & $\begin{array}{l}\text { Discussão e votação do Regime Interno da } \\
\text { Comissão. O Sr. Presidente comunica que os } \\
\text { formulários para apresentação de emendas deverão } \\
\text { ser entregues a partir do dia } 28 \text { com encerramento a } \\
3 / 7 / 87\end{array}$ & $\frac{8 / 7 / 1987}{\text { Supl. } 90 \text { p. } 180}$ \\
\hline $5^{\mathrm{a}}$ & $28 / 5 / 1987$ & $\begin{array}{l}\text { Alteração no Regimento Interno. Discussão do } \\
\text { Anteprojeto da Subcomissão da Educação, Cultura e } \\
\text { Esporte. Definição do prazo para recebimento de } \\
\text { emendas }\end{array}$ & $\frac{8 / 7 / 1987}{\text { Supl. } 90 \text { p. } 193}$ \\
\hline $6^{\mathrm{a}}$ & $28 / 5 / 1987$ & $\begin{array}{l}\text { Indicação de nomes para audiência pública. } \\
\text { Discussão do Anteprojeto da Subcomissão de } \\
\text { Educação, Cultura e Esportes }\end{array}$ & $\frac{8 / 7 / 1987}{\text { Supl. } 90 \text { p. } 201}$ \\
\hline 1르. EXT. & $29 / 5 / 1987$ & $\begin{array}{l}\text { Discussão do Anteprojeto da Subcomissão da } \\
\text { Ciência e Tecnologia e da Comunicação }\end{array}$ & $\frac{8 / 7 / 1987}{\text { Supl. } 90 \text { p. } 206}$ \\
\hline \multirow{2}{*}{$2^{\underline{a}}$ EXT. } & 1/6/1987 & $\begin{array}{l}\text { Discussão do Anteprojeto da Subcomissão da } \\
\text { Família, do Menor e do Idoso. Informação a respeito } \\
\text { dos prazos estipulados para apresentação de } \\
\text { emendas }\end{array}$ & Supl. 90 p. 207 \\
\hline & $1 / 6 / 1987$ & $\begin{array}{l}\text { Leitura do expediente encaminhado pelo Presidente } \\
\text { da Assembleia Nacional Constituinte que trata da } \\
\text { apresentação de emendas ao Substitutivo oferecido } \\
\text { pelos Relatores }\end{array}$ & $\frac{8 / 7 / 1987}{\text { Supl. } 90 \text { p. } 219}$ \\
\hline $7^{a}$ & 2/6/1987 & $\begin{array}{l}\text { Discussão do Anteprojeto da Subcomissão da } \\
\text { Educação, Cultura e Esportes }\end{array}$ & $\frac{9 / 7 / 1987}{\text { Supl. } 91 \text { p. } 250}$ \\
\hline $8^{\underline{a}}$ & 3/6/1987 & $\begin{array}{l}\text { Discussão do Anteprojeto da Subcomissão da } \\
\text { Ciência e Tecnologia e da Comunicação. Audiência } \\
\text { Pública } \\
\text { Assuntos: Mercado brasileiro de química fina / } \\
\text { Manipulação genética / Genética humana / }\end{array}$ & $\frac{9 / 7 / 1987}{\text { Supl. } 91 \text { p. } 274}$ \\
\hline
\end{tabular}

78 Elaborada a partir de quadros disponíveis em: <http://www2.camara.leg.br/atividadelegislativa/legislacao/Constituicoes Brasileiras/constituicao-cidada/o-processoconstituinte/comissoes-e-subcomissoes/comissao8/comissa08>. Acesso em 23 nov. 2014. ETAPAS/FASES - E: Emenda aos Anteprojetos das Subcomissões na Comissão; F: Substitutivo do Relator; G: Emenda ao Substitutivo; H: Anteprojeto da Comissão. 


\begin{tabular}{|c|c|c|c|}
\hline & & Educação & \\
\hline $9^{a}$ & $4 / 6 / 1987$ & $\begin{array}{l}\text { Audiência Pública } \\
\text { Assuntos: Política de comunicação no Brasil }\end{array}$ & $\frac{9 / 7 / 1987}{\text { Supl. } 91 \text { p. } 303}$ \\
\hline 3르. EXT. & $4 / 6 / 1987$ & Comunicações de ordem interna & $\frac{9 / 7 / 1987}{\text { Supl. } 91 \text { p. } 332}$ \\
\hline $10^{\mathrm{a}}$ & $9 / 6 / 1987$ & $\begin{array}{l}\text { Leitura do Substitutivo do Relator e início da } \\
\text { discussão }\end{array}$ & $\frac{21 / 7 / 1987}{\text { Supl. } 100 \text { p. } 192}$ \\
\hline $11^{a}$ & $10 / 6 / 1987$ & $\begin{array}{l}\text { Audiência Pública } \\
\text { Assuntos: Política social brasileira }\end{array}$ & $\frac{23 / 7 / 1987}{\text { Supl. } 102 \text { p. } 166}$ \\
\hline $12^{\mathrm{a}}$ & $10 / 6 / 1987$ & $\begin{array}{l}\text { Leitura do expediente do Presidente da ANC, quanto } \\
\text { às normas do processo de votação }\end{array}$ & $\frac{24 / 7 / 1987}{\text { Supl. } 103 \text { p. } 165}$ \\
\hline $13^{\mathrm{a}}$ & $11 / 6 / 1987$ & Discussão do Substitutivo do Relator & $\frac{24 / 7 / 1987}{\text { Supl. } 103 \text { p. } 166}$ \\
\hline $4^{\mathrm{a}}$ EXT. & $12 / 6 / 1987$ & $\begin{array}{l}\text { Apresentação e discussão do Segundo Substitutivo } \\
\text { do Relator }\end{array}$ & $\frac{9 / 7 / 1987}{\text { Supl. } 91 \text { p. } 333}$ \\
\hline \multirow{6}{*}{ 5르. EXT. } & $12 / 6 / 1987$ & $\begin{array}{l}\text { Verificação de quórum. } \\
\text { Comunicações de ordem interna }\end{array}$ & Supl. 114 p. 172 \\
\hline & $13 / 6 / 1987$ & Votação do Substitutivo Final do Relator. Rejeitado & $\frac{4 / 8 / 1987}{\text { Supl. } 114 \text { p. } 173}$ \\
\hline & $13 / 6 / 1987$ & $\begin{array}{l}\text { Votação do Primeiro Substitutivo. Rejeitado. } \\
\text { Comunicações de ordem interna }\end{array}$ & $\frac{4 / 8 / 1987}{\text { Supl. } 114 \text { p. } 173}$ \\
\hline & $13 / 6 / 1987$ & $\begin{array}{l}\text { Votação do Primeiro Substitutivo. Rejeitado. } \\
\text { Comunicações de ordem interna }\end{array}$ & $\frac{4 / 8 / 1987}{\text { Supl. } 114 \text { p. } 173}$ \\
\hline & $14 / 6 / 1987$ & $\begin{array}{l}\text { Votação das emendas. } \\
\text { Encaminhado o Substitutivo da maioria à Comissão } \\
\text { de Sistematização }\end{array}$ & Supl. 114 p. 174 \\
\hline & $14 / 6 / 1987$ & $\begin{array}{l}\text { Votação das emendas. } \\
\text { Encaminhado o Substitutivo da maioria à Comissão } \\
\text { de Sistematização }\end{array}$ & $\stackrel{4 / 8 / 1987}{\text { Supl. } 114 \text { p. } 174}$ \\
\hline
\end{tabular}




\section{ANEXO I - CONSTITUINTES MEMBROS DA SUBCOMISSÃO VIII-A 79}

Assembleia Nacional Constituinte

Subcomissão VIII A - da Educação, Cultura e Esportes

Comissão VIII - da Família, da Educação, Cultura e Esportes, da Ciência e Tecnologia e da Comunicação

Presidente: Hermes Zaneti (PMDB-PR)

$1^{\circ}$ Vice-Presidente: Aécio Borba (PDS-CE)

$2^{\circ}$ Vice-Presidente: Pedro Canedo (PFL-GO)

Relator: João Calmon (PMDB-ES)

\begin{tabular}{|c|c|}
\hline TITULARES & SUPLENTES \\
\hline \multicolumn{2}{|c|}{ PMDB } \\
\hline $\begin{array}{l}\text { 1. João Calmon; } \\
\text { 2. Louremberg Nunes Rocha; } \\
\text { 3. Antônio de Jesus; } \\
\text { 4. Bezerra de Melo; } \\
\text { 5. Hermes Zaneti; } \\
\text { 6. Márcia Kubitschek; } \\
\text { 7. Octávio Elísio; } \\
\text { 8. Osvaldo Sobrinho; } \\
\text { 9. Paulo Silva; } \\
\text { 10. Tadeu França; } \\
\text { 11. Ubiratan Aguiar; } \\
\text { 12. Flávio Palmier da Veiga; } \\
\text { 13. França Teixeira. }\end{array}$ & $\begin{array}{l}\text { Irapuan Costa Júnior; } \\
\text { Carlos Benevides; } \\
\text { Eduardo Moreira; } \\
\text { Felipe Cheidde; } \\
\text { Ivo Lech; } \\
\text { Jorge Hage; } \\
\text { José Carlos Sabóia; } \\
\text { José Dutra; } \\
\text { Leopoldo Bessone; } \\
\text { Mário de Oliveira; } \\
\text { Maurício Nasser; } \\
\text { Renato Bernardi. }\end{array}$ \\
\hline \multicolumn{2}{|l|}{ 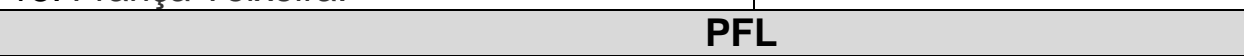 } \\
\hline $\begin{array}{l}\text { 1. Átila Lira; } \\
\text { 2. Cláudio Ávila; } \\
\text { 3. José Moura; } \\
\text { 4. José Queiroz; } \\
\text { 5. Pedro Canedo; } \\
\text { 6. Agripino Lima; } \\
\text { 7. Dionísio Hage }\end{array}$ & $\begin{array}{l}\text { Evaldo Gonçalves; } \\
\text { Geovani Borges; } \\
\text { Pedro Ceolin; } \\
\text { Francisco Coelho; } \\
\text { Eraldo Trindade. }\end{array}$ \\
\hline \multicolumn{2}{|c|}{ PDS } \\
\hline 1. Aécio Borba. & RubervalPilloto. \\
\hline \multicolumn{2}{|c|}{ PDT } \\
\hline 1. Chico Humberto. & Vago. \\
\hline \multicolumn{2}{|c|}{ PTB } \\
\hline 1. Sólon Borges dos Reis. & Fábio Raunheitti \\
\hline \multicolumn{2}{|l|}{ (2) } \\
\hline 1. Florestan Fernandes. & Gumercindo Milhomen \\
\hline \multicolumn{2}{|c|}{ PL } \\
\hline 1. Álvaro Valle. & José Carlos Coutinho \\
\hline
\end{tabular}

79 Organizado a partir de lista disponível em: $<$ http://www2.camara.leg.br/atividadelegislativa/legislacao/Constituicoes Brasileiras/constituicao-cidada/o-processoconstituinte/comissoes-e-subcomissoes/comissao8/subcomissa08a>. Acesso em: 23 nov. 2014. 


\section{ANEXO J - CRONOLOGIA DE REUNIÕES DA SUBCOMISSÃO VIII-A 80}

\begin{tabular}{|c|c|c|c|}
\hline Reunião & Data & Objeto & Diário da ANC \\
\hline $1 \stackrel{\text { a. }}{\text {. }}$ & 7/4/1987 & $\begin{array}{l}\text { Instalação e eleição do Presidente e Vice- } \\
\text { Presidentes }\end{array}$ & Supl. 53 p. 196 \\
\hline $2^{\mathrm{a}}$ & 9/4/1987 & $\begin{array}{l}\text { Leitura de nomes de entidades e autoridades } \\
\text { propostas pelo Presidente. Sugestão para que } \\
\text { cada Constituinte elabore uma proposta de } \\
\text { nomes de entidades e de autoridades. } \\
\text { Propostas de calendário para as audiências } \\
\text { públicas }\end{array}$ & $\begin{array}{l}\frac{1 / 5 / 1987}{\text { Supl. } 53 \text { p. } 197} \\
\text { Supl. } 56 \text { p. } 157 \\
\end{array}$ \\
\hline $3^{\mathrm{a}}$. & $9 / 4 / 1987$ & $\begin{array}{l}\text { Destaque de Assunto. O Turismo e o Lazer, } \\
\text { inclusive o Jogo, como assuntos pertinentes } \\
\text { aos trabalhos da Subcomissão. Votação do } \\
\text { calendário de audiências públicas }\end{array}$ & $\begin{array}{l}\frac{1 / 5 / 1987}{\text { Supl. } 53 \text { p. } 197} \\
\text { Supl. } 56 \text { p. } 164 \\
\end{array}$ \\
\hline 4 a & $13 / 4 / 1987$ & $\begin{array}{l}\text { Termo de reunião. Não houve quórum. O } \\
\text { Senhor Presidente convoca para reunião } \\
\text { extraordinária }\end{array}$ & $\frac{1 / 5 / 1987}{\text { Supl. } 53 \text { p. } 197}$ \\
\hline $5^{\mathrm{a}}$ & $13 / 4 / 1987$ & Termo de reunião. Não houve quórum & $\frac{1 / 5 / 1987}{\text { Supl. } 53 \text { p. } 197}$ \\
\hline 6 . & $14 / 4 / 1987$ & Termo de reunião. Não houve quórum & Supl. 53 p. 197 \\
\hline 7a. EXT. & $14 / 4 / 1987$ & $\begin{array}{l}\text { Leitura e aprovação do calendário das } \\
\text { reuniões de audiência pública }\end{array}$ & $\begin{array}{l}\frac{1 / 5 / 1987}{\text { Supl. } 53 \text { p. } 197} \\
\text { 20/5/1987 } \\
\text { Supl. } 62 \text { p. } 168 \\
\end{array}$ \\
\hline 8 & $15 / 4 / 1987$ & $\begin{array}{l}\text { Termo de reunião. Não houve reunião por falta } \\
\text { de quórum }\end{array}$ & Supl. 95 p. 135 \\
\hline $9^{\mathrm{a}}$ & $21 / 4 / 1987$ & $\begin{array}{l}\text { Sugestões dos Srs. Constituintes. } \\
\text { Aposentadoria para o professor; recursos para } \\
\text { a educação; verba adicional para a educação, } \\
\text { durante quatro anos; e outros assuntos } \\
\text { ligados à educação }\end{array}$ & $\frac{16 / 7 / 1987}{\text { Supl. } 95 \text { p. } 135}$ \\
\hline $\begin{array}{l}10^{\mathrm{a}} \text {. } \\
\text { EXT. }\end{array}$ & $21 / 4 / 1987$ & $\begin{array}{l}\text { Discussão de matéria pertinente à área da } \\
\text { Subcomissão }\end{array}$ & $\frac{16 / 7 / 1987}{\text { supl. } 95 \text { p. } 149}$ \\
\hline $11^{\mathrm{a}}$. & $22 / 4 / 1987$ & $\begin{array}{l}\text { Comunicação a respeito das autoridades que } \\
\text { farão exposição sobre educação e esporte; } \\
\text { fiscalização de recursos para a escola } \\
\text { particular; orçamento do MEC etc. }\end{array}$ & $\frac{16 / 7 / 1987}{\text { Supl. } 95 \text { p. } 158}$ \\
\hline
\end{tabular}

${ }_{80}$ Elaborada a partir de quadros disponíveis em <http://www2.camara.leg.br/atividadelegislativa/legislacao/Constituicoes Brasileiras/constituicao-cidada/o-processoconstituinte/comissoes-e-subcomissoes/comissao8/subcomissa08a>. Acesso em 23/11/2014. ETAPAS/FASES - A: Anteprojeto do Relator; B: Emenda ao Anteprojeto do Relator; C: Anteprojeto da Subcomissão. 


\begin{tabular}{|c|c|c|c|}
\hline $12^{\mathrm{a}}$ & 23/4/1987 & $\begin{array}{l}\text { Comunicação de ordem administrativa. } \\
\text { Audiência Pública } \\
\text { Assuntos: Poderes públicos e educação / } \\
\text { Ensino básico / Educação de adultos / Ensino } \\
\text { superior / Valorização do docente de ensino } \\
\text { superior / Inteiração da educação física na } \\
\text { educação / Administração da educação / } \\
\text { Deterioração do ensino público }\end{array}$ & $\frac{16 / 7 / 1987}{\text { Supl. } 95 \text { p. } 170}$ \\
\hline $\begin{array}{l}13^{\underline{a}} \\
\text { EXT. }\end{array}$ & 23/4/1987 & $\begin{array}{l}\text { Audiência Pública } \\
\text { Assuntos: Educação e a Constituinte / Direito à } \\
\text { educação e dever do Estado / Política nacional } \\
\text { de educação }\end{array}$ & $\frac{17 / 7 / 1987}{\text { Supl. } 96 \text { p. } 207}$ \\
\hline $\begin{array}{l}14^{\underline{a}} . \\
\text { EXT. }\end{array}$ & $27 / 4 / 1987$ & $\begin{array}{l}\text { Análise do cronograma elaborado para as } \\
\text { audiências públicas }\end{array}$ & $\frac{17 / 7 / 1987}{\text { Supl. } 96 \text { p. } 225}$ \\
\hline $15^{\mathrm{a}}$ & $28 / 4 / 1987$ & $\begin{array}{l}\text { Audiência Pública } \\
\text { Assuntos: Ensino público e gratuito / } \\
\text { Reestruturação do ensino / Investimento na } \\
\text { área educacional / Escola pública / } \\
\text { Democratização do ensino / Salário educação }\end{array}$ & $\frac{17 / 7 / 1987}{\text { Supl. } 96 \text { p. } 237}$ \\
\hline $16^{\mathrm{a}}$ & 29/4/1987 & $\begin{array}{l}\text { Audiência Pública } \\
\text { Assuntos: Educação escolar indígena / } \\
\text { Universidades católicas / Escolas comunitárias } \\
\text { / Cultura das populações indígenas / } \\
\text { Reabilitação e educação especial / } \\
\text { Democracia plural na educação / } \\
\text { Mercantilismo e educação / Estado e } \\
\text { educação }\end{array}$ & $\frac{17 / 7 / 1987}{\text { Supl. } 96 \text { p. } 297}$ \\
\hline $17^{a}$ & $30 / 4 / 1987$ & $\begin{array}{l}\text { Audiência Pública } \\
\text { Assuntos: Educação gratuita e integral / } \\
\text { Democratização da educação / Condições de } \\
\text { trabalho dos professores / Ensino das ciências } \\
\text { farmacêuticas / Influência do colonizador sobre } \\
\text { o negro / Discriminação racial / Verbas } \\
\text { públicas / Ensino cooperativista / Escolas } \\
\text { particulares }\end{array}$ & $\frac{18 / 7 / 1987}{\text { Supl. } 97 \text { p. } 140}$ \\
\hline $18^{\mathrm{a}}$ & 4/5/1987 & $\begin{array}{l}\text { Decisões de natureza administrativa e } \\
\text { constitucional }\end{array}$ & $\frac{18 / 7 / 1987}{\text { Supl. } 97 \text { p. } 174}$ \\
\hline $19^{\mathrm{a}}$ & $5 / 5 / 1987$ & $\begin{array}{l}\text { Audiência Pública } \\
\text { Assuntos: Acesso aos bens culturais / } \\
\text { Extinção da censura / Criação do Conselho } \\
\text { Nacional de Comunicação / Censura meios de } \\
\text { comunicação de massa / Religião e cultura / } \\
\text { Dança como expressão cultural / Arte como } \\
\text { matéria de currículo escolar / Direito autoral / } \\
\text { Sistema nacional de museus / Cultura na nova } \\
\text { Constituição / Ensino religioso no processo } \\
\text { educacional / Cultura e ordem social / } \\
\text { Liberdade de expressão / Educação artística }\end{array}$ & $\frac{18 / 7 / 1987}{\text { Supl. } 97 \text { p. } 178}$ \\
\hline
\end{tabular}




\begin{tabular}{|c|c|c|c|}
\hline $20^{a}$. & 6/5/1987 & $\begin{array}{l}\text { Audiência Pública } \\
\text { Assuntos: Patrimônio histórico e artístico } \\
\text { nacional / Cinema / Liberdade de expressão / } \\
\text { Política nacional do livro / Biblioteca como } \\
\text { centro de informações e cultura / Preservação } \\
\text { e direito à Cultura }\end{array}$ & \multirow{3}{*}{$\begin{array}{l}\frac{19 / 7 / 1987}{\text { Supl. } 98 \text { p. } 165} \\
\text { Supl. } 98 \text { p. } 210 \\
\end{array}$} \\
\hline $21 \stackrel{a}{ }$. & $7 / 5 / 1987$ & $\begin{array}{l}\text { Audiência Pública } \\
\text { Assuntos: Autonomia às entidades esportivas / } \\
\text { Discriminação no desporto / Justiça desportiva } \\
\text { / Educação física e esporte / Turismo / } \\
\text { Educação, cultura e esporte / } \\
\text { Desenvolvimento econômico e social pelo } \\
\text { turismo }\end{array}$ & \\
\hline $22^{a}$. & $8 / 5 / 1987$ & $\begin{array}{l}\text { Audiência Pública } \\
\text { Assuntos: Liberdade editorial / Turismo / } \\
\text { Indústria turística brasileira / Reforma } \\
\text { educacional / Esporte amador / Turismo } \\
\text { estudantil e juvenil / Educação e assistência à } \\
\text { criança / Assistência à educação popular / } \\
\text { Política de desenvolvimento para a Amazônia }\end{array}$ & \\
\hline $23^{\mathrm{a}}$. & $11 / 5 / 1987$ & \multicolumn{2}{|c|}{$\begin{array}{l}\text { LEITURA DO RELATÓRIO } \\
\text { DIÁRIO DA ASSEMBLÉIA NACIONAL CONSTITUINTE. } \\
\text { Suplemento. Número 98. Brasília: ANC, } 19 \text { Julho de 1987, p. } \\
242-253 .\end{array}$} \\
\hline $24^{\mathrm{a}}$. & $12 / 5 / 1987$ & $\begin{array}{l}\text { Audiência Pública } \\
\text { Assuntos: Preservação do patrimônio e da } \\
\text { memória cultural }\end{array}$ & $\begin{array}{l}\frac{20 / 7 / 1987}{\text { Supl. } 99 \text { p. } 211} \\
\end{array}$ \\
\hline $25^{\mathrm{a}}$ & $13 / 5 / 1987$ & $\begin{array}{l}\text { Audiência Pública } \\
\text { Assuntos: Problemas do orçamento do } \\
\text { Ministério da Educação }\end{array}$ & $\begin{array}{l}\frac{20 / 7 / 1987}{\text { Supl. } 99 \text { p. } 228} \\
\end{array}$ \\
\hline $26^{\mathrm{a}}$ & $14 / 5 / 1987$ & Debates iniciais sobre o relatório & $\begin{array}{l}\frac{20 / 7 / 1987}{\text { Supl. } 99 \text { p. } 251} \\
\end{array}$ \\
\hline $27^{\mathrm{a}}$ & $14 / 5 / 1987$ & Termo de Reunião & $\begin{array}{l}\frac{20 / 7 / 1987}{\text { Supl. } 99 \text { p. } 260} \\
\end{array}$ \\
\hline $28^{\mathrm{a}}$. & $15 / 5 / 1987$ & $\begin{array}{l}\text { Entrega jornal à Subcomissão da segunda } \\
\text { parte do relatório. Votado e aprovado o } \\
\text { cronograma }\end{array}$ & $\begin{array}{l}\frac{20 / 7 / 1987}{\text { Supl. } 99 \text { p. } 260} \\
\end{array}$ \\
\hline 29a. & $18 / 5 / 1987$ & $\begin{array}{l}\text { DISCUSSÃO DO ANTEPROJETO } \\
\text { DIÁRIO DA ASSEMBLÉIA NACIONAL } \\
\text { Suplemento. Número 99. Brasília: ANC, } 20 \mathrm{~J} \\
260-275 .\end{array}$ & $\begin{array}{l}\text { CONSTITUINTE. } \\
\text { ulho de 1987, p. }\end{array}$ \\
\hline $30^{\mathrm{a}}$. & $18 / 5 / 1987$ & $\begin{array}{l}\text { Audiência Pública } \\
\text { Assuntos: Revisão das escolas normais / } \\
\text { Alfabetização de adultos / Escola pública }\end{array}$ & $\frac{\frac{21 / 7 / 1987}{\text { Supl. } 100}}{\text { p. } 221}$ \\
\hline $31^{a}$ & $19 / 5 / 1987$ & Análise preliminar do Anteprojeto & $\frac{\frac{21 / 7 / 1987}{\text { Supl. } 100}}{\text { p. } 227}$ \\
\hline
\end{tabular}




\begin{tabular}{|c|c|c|c|}
\hline $32 \stackrel{\text { a. }}{ }$ & 20/5/1987 & \multicolumn{2}{|c|}{$\begin{array}{l}\text { DISCUSSÃO DO ANTEPROJETO. AUDIÊNCIAS PÚBLICAS } \\
\text { ASSUNTOS: DEMOCRATIZAÇÃO DA EDUCAÇÃO NA } \\
\text { AMÉRICA LATINA E NO CARIBE/COOPERAÇÃO DA UNESCO } \\
\text { DIÁRIO DA ASSEMBLÉIA NACIONAL CONSTITUINTE. } \\
\text { Suplemento. Número 101. Brasília: ANC, } 22 \text { Julho de 1987, p. } \\
\text { 177-189. }\end{array}$} \\
\hline $33^{a}$. & 22/5/1987 & $\begin{array}{l}\text { Leitura do Substitutivo do Anteprojeto. } \\
\text { Aprovação das normas para a votação do } \\
\text { Substitutivo }\end{array}$ & $\frac{\frac{22 / 7 / 1987}{\text { Supl. } 101}}{\underline{\text { p. } 189}}$ \\
\hline $34^{\mathrm{a}}$. & 23/5/1987 & $\begin{array}{l}\text { Suspensa a reunião para organização dos } \\
\text { requerimentos de destaques. Votação do } \\
\text { Substitutivo do Relator }\end{array}$ & $\frac{\frac{23 / 7 / 1987}{\text { Supl. } 102}}{\text { p. } 182}$ \\
\hline $35^{\underline{a}}$. & $25 / 5 / 1987$ & Apresentação da redação final do Anteprojeto & $\frac{24 / 7 / 1987}{\frac{\text { Supl. } 103}{\text { p. } 169}}$ \\
\hline
\end{tabular}




\section{ANEXO K - QUADRO DAS AUDIÊNCIAS PÚBLICAS DA SUBCOMISSÃO VIII-A 81}

\begin{tabular}{|c|c|c|c|}
\hline \multirow{2}{*}{$\begin{array}{c}\text { REUNIÃO } \\
\text { № E } \\
\text { DATA }\end{array}$} & \multicolumn{2}{|c|}{ EXPOSITOR } & \multirow[b]{2}{*}{ ASSUNTO } \\
\hline & NOME & QUALIFICAÇÃO & \\
\hline \multirow{7}{*}{$\begin{array}{c}12^{\mathrm{a}}(1) \\
23 / 4 / 1987\end{array}$} & $\begin{array}{l}\text { ELBA SIQUEIRA DE SÁ } \\
\text { BARRETO }\end{array}$ & $\begin{array}{l}\text { Presidente da Associação } \\
\text { Nacional da Educação } \\
\text { (Ande) }\end{array}$ & $\begin{array}{l}\text { O descompromisso } \\
\text { dos poderes } \\
\text { públicos com a } \\
\text { educação no país }\end{array}$ \\
\hline & NOVELINO & $\begin{array}{ll}\text { Representante } & \text { da } \\
\text { Associação Nacional da } & \text { Educação }\end{array}$ & $\begin{array}{ll}\text { Ensino básico } & - \\
\text { educação } & \text { de } \\
\text { adultos } & \end{array}$ \\
\hline & NEWTON LIMA NETO & $\begin{array}{l}\text { Presidente da Associação } \\
\text { Nacional dos } \\
\text { do Enocentes } \\
\text { (Andes) }\end{array}$ & Ensino superior \\
\hline & $\begin{array}{l}\text { MIRIAM } \\
\text { CARDOSO }\end{array}$ & $\begin{array}{l}\text { Diretora da Associação } \\
\text { dos Docentes do Ensino } \\
\text { Superior }\end{array}$ & $\begin{array}{l}\text { Valorização do } \\
\text { docente de ensino } \\
\text { superior: } \\
\text { democratização da } \\
\text { gestão da educação } \\
\text { no país }\end{array}$ \\
\hline & CLÁUDIO BOSCHI & $\begin{array}{l}\text { Presidente da Federação } \\
\text { Brasileira das } \\
\text { Associações } \\
\text { Professores de Educação } \\
\text { Física }\end{array}$ & $\begin{array}{l}\text { Educação Física e } \\
\text { educação }\end{array}$ \\
\hline & $\begin{array}{ll}\text { MARIA } & \text { BEATRIZ } \\
\text { MOREIRA LUCE } & \end{array}$ & $\begin{array}{l}\text { Presidente da Associação } \\
\text { Nacional de Profissionais } \\
\text { de Administração da } \\
\text { Educação (Anpae) }\end{array}$ & $\begin{array}{l}\text { Administração } \\
\text { educação }\end{array}$ \\
\hline & LUIZ ANTÔNIO CUNHA & $\begin{array}{l}\text { Professor e representante } \\
\text { da Sociedade para o } \\
\text { Progresso da Ciência } \\
\text { (SBPC) }\end{array}$ & $\begin{array}{l}\text { Deterioração } \\
\text { ensino público }\end{array}$ \\
\hline \multirow{4}{*}{$\begin{array}{c}13^{\mathbf{a}}(2) \\
23 / 4 / 1987\end{array}$} & $\begin{array}{l}\text { OSWALDO } \\
\text { GIUSTINA }\end{array}$ & $\begin{array}{l}\text { Grupo de trabalho: } \\
\text { Educação e Constituinte, } \\
\text { do Ministério da } \\
\text { Educação }\end{array}$ & $\begin{array}{l}\text { Educação e } \\
\text { Constituinte }\end{array}$ \\
\hline & ERNANY BAYER & $\begin{array}{l}\text { Grupo de trabalho: } \\
\text { Educação e Constituinte, } \\
\text { do Ministério da } \\
\text { Educação }\end{array}$ & $\begin{array}{l}\text { Educação e } \\
\text { Constituinte }\end{array}$ \\
\hline & $\begin{array}{l}\text { FERNANDO GAY DA } \\
\text { FONSECA }\end{array}$ & $\begin{array}{l}\text { Presidente do Conselho } \\
\text { Federal de Educação }\end{array}$ & $\begin{array}{l}\text { Direito à educação } \\
\text { é dever do Estado }\end{array}$ \\
\hline & $\begin{array}{l}\text { GILDA POLI ROCHA } \\
\text { LOURES }\end{array}$ & $\begin{array}{l}\text { Representante do } \\
\text { Conselho Nacional dos } \\
\text { Secretários de Educação }\end{array}$ & $\begin{array}{l}\text { Política Nacional de } \\
\text { Educação }\end{array}$ \\
\hline
\end{tabular}

81 BACKES, Ana Luiza; AZEVEDO, Débora Bithiah de; ARAÚJO, José Cordeiro de (orgs.). Audiências Públicas na Assembleia Nacional Constituinte: a Sociedade na Tribuna. Brasília: Câmara dos Deputados, 2009, p. 543 -64, (3 v.). 


\begin{tabular}{|c|c|c|c|}
\hline \multirow{9}{*}{$\begin{array}{c}15^{\mathrm{a}}(3) \\
28 / 4 / 1987\end{array}$} & $\begin{array}{l}\text { TOMÁS GILIAN DELUCA } \\
\text { WONGTON }\end{array}$ & $\begin{array}{l}\text { Professor e presidente da } \\
\text { Confederação do dos } \\
\text { Professores do Brasil } \\
\text { (CPB) }\end{array}$ & $\begin{array}{l}\text { Ensino público e } \\
\text { gratuito }\end{array}$ \\
\hline & $\begin{array}{l}\text { VÂNIA MARIA GALVÃO } \\
\text { DE CARVALHO }\end{array}$ & \begin{tabular}{lr}
\multicolumn{2}{l}{ Professora e presidente } \\
da Federação das \\
Associações & de \\
Servidores rrasileiras \\
Universidades \\
(Fasubra)
\end{tabular} & $\begin{array}{l}\text { Ensino público e } \\
\text { gratuito; qualidade } \\
\text { do ensino }\end{array}$ \\
\hline & $\begin{array}{l}\text { JOSÉ FERREIRA DE } \\
\text { ALENCAR }\end{array}$ & Diretor da Fasubra & $\begin{array}{l}\text { Ensino público e } \\
\text { gratuito; qualidade } \\
\text { do ensino }\end{array}$ \\
\hline & $\begin{array}{l}\text { HENRIQUE NIELSEN } \\
\text { NETO }\end{array}$ & 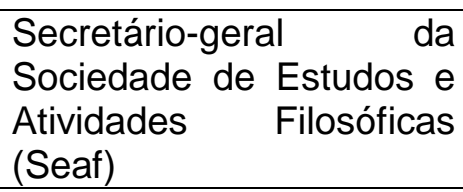 & $\begin{array}{l}\text { Reestruturação do } \\
\text { ensino no país }\end{array}$ \\
\hline & $\begin{array}{ll}\text { RODOLFO JOAQUIM } \\
\text { PINTO DA LUZ }\end{array}$ & $\begin{array}{l}\text { Presidente do } \text { Conselho } \\
\text { de Reitores das } \\
\text { Universidades Brasileiras } \\
\text { (Crub) }\end{array}$ & $\begin{array}{l}\text { Investimentos na } \\
\text { área educacional }\end{array}$ \\
\hline & ROVILSON ROBBI BRITO & $\begin{array}{l}\text { Presidente da União } \\
\text { Brasileira dos Estudantes } \\
\text { Secundários (Ubes) }\end{array}$ & $\begin{array}{l}\text { Escola pública e } \\
\text { gratuita }\end{array}$ \\
\hline & OSMAR FAVERO & $\begin{array}{l}\text { Presidente da Associação } \\
\text { Nacional de Pós- } \\
\text { Graduação e Pesquisa } \\
\text { em Educação (Anped) }\end{array}$ & $\begin{array}{l}\text { Ensino público e } \\
\text { gratuito: } \\
\text { democratização do } \\
\text { ensino }\end{array}$ \\
\hline & $\begin{array}{l}\text { ELIZABETH POMPEU DE } \\
\text { CAMARGO }\end{array}$ & $\begin{array}{l}\text { Diretora do Centro de } \\
\text { Estudos e Educação e } \\
\text { Sociedade }\end{array}$ & $\begin{array}{l}\text { Ensino público e } \\
\text { gratuito: } \\
\text { democratização do } \\
\text { ensino }\end{array}$ \\
\hline & JAQUES VELOSO & $\begin{array}{lr}\text { Representante } & \text { da } \\
\text { Associação Nacional de } \\
\text { Pós-Graduação } \\
\text { Pesquisa em Educação } \\
\text { (Anped) }\end{array}$ & Salário-Educação \\
\hline \multirow{5}{*}{$\begin{array}{c}16^{\mathbf{a}}(\mathbf{4}) \\
29 / 4 / 1987\end{array}$} & $\begin{array}{l}\text { MARINA KAHN VILLAS } \\
\text { BOAS }\end{array}$ & $\begin{array}{l}\text { Representante do Centro } \\
\text { do Trabalho Indigenista } \\
\text { (CTI) }\end{array}$ & $\begin{array}{l}\text { Educação escolar } \\
\text { indígena }\end{array}$ \\
\hline & $\begin{array}{l}\text { WALDEMAR } \\
\text { MARTINS }\end{array}$ & $\begin{array}{l}\text { Representante } \\
\text { Associação Brasileira de } \\
\text { Escolas } \quad \text { Superiores } \\
\text { Católicas (Abesc) }\end{array}$ & $\begin{array}{l}\text { Universidades } \\
\text { católicas }\end{array}$ \\
\hline & FELIPE TIAGO GOMES & $\begin{array}{l}\text { Presidente da Campanha } \\
\text { Nacional de Escolas da } \\
\text { Comunidade (Cnec) }\end{array}$ & $\begin{array}{l}\text { Escolas } \\
\text { comunitárias }\end{array}$ \\
\hline & AILTON KRENAK & $\begin{array}{l}\text { Representante da União } \\
\text { das Nações Indígenas }\end{array}$ & $\begin{array}{l}\text { Cultura } \\
\text { populações } \\
\text { indígenas }\end{array}$ \\
\hline & $\begin{array}{l}\text { PAULO ROBERTO DE } \\
\text { GUIMARÃESMOREIRA }\end{array}$ & \begin{tabular}{lr}
\multicolumn{2}{l}{ Representante do Fórum } \\
Nacional das & Pessoas \\
Portadoras de Deficiência \\
e $\quad$ da & Comissão
\end{tabular} & $\begin{array}{l}\text { Reabilitação e } \\
\text { educação especial }\end{array}$ \\
\hline
\end{tabular}




\begin{tabular}{|c|c|c|c|}
\hline & & $\begin{array}{l}\text { Parlamentar da } \\
\text { Organização de Entidade } \\
\text { de Deficientes Físicos }\end{array}$ & \\
\hline & $\begin{array}{l}\text { ROBERTO GERALDO DE } \\
\text { PAIVADORNAS }\end{array}$ & \begin{tabular}{|lr} 
Presidente da Federação \\
Nacional dos \\
Estabelecimentos de \\
Ensino (Fenem) \\
\end{tabular} & $\begin{array}{l}\text { Democracia plural } \\
\text { na educação }\end{array}$ \\
\hline & $\begin{array}{l}\text { GISELA } \\
\text { MENDONÇA }\end{array}$ & Presidente da UNE & $\begin{array}{l}\text { Mercantilismo } \\
\text { educação }\end{array}$ \\
\hline & AGOSTINHO CASTEJON & $\begin{array}{l}\text { Padre e presidente da } \\
\text { Associação de Educação } \\
\text { Católica do Brasil }\end{array}$ & $\begin{array}{l}\text { O Estado e a } \\
\text { educação }\end{array}$ \\
\hline \multirow{11}{*}{$\begin{array}{c}17^{\mathrm{a}}(5) \\
29 / 4 / 1987\end{array}$} & $\begin{array}{l}\text { ALCIDES VITOR DE } \\
\text { CARVALHO }\end{array}$ & \begin{tabular}{|lr} 
Diretor da Federação dos \\
Trabalhadores em \\
Estabelecimentos de \\
Ensino (Fetee) da Região \\
Sul \\
\end{tabular} & $\begin{array}{l}\text { Educação gratuita e } \\
\text { integral }\end{array}$ \\
\hline & $\begin{array}{l}\text { JOSÉ ROBERTO TORRES } \\
\text { MACHADO }\end{array}$ & $\begin{array}{l}\text { Presidente da Federação } \\
\text { dos Trabalhadores de } \\
\text { Ensino - Região Sul }\end{array}$ & $\begin{array}{l}\text { Aplicação das } \\
\text { verbas públicas }\end{array}$ \\
\hline & $\begin{array}{l}\text { CARLOS MAGNO DE } \\
\text { CASTELO BRANCO }\end{array}$ & $\begin{array}{l}\text { Presidente do Sindicato } \\
\text { dos Professores do } \\
\text { Estado de Minas Gerais }\end{array}$ & $\begin{array}{l}\text { Condições } \\
\text { trabalho } \\
\text { professores }\end{array}$ \\
\hline & $\begin{array}{l}\text { CARLOS COUTO DE } \\
\text { CASTELO BRANCO }\end{array}$ & $\begin{array}{l}\text { Representante do } \\
\text { Conselho Federal de } \\
\text { Farmácia e presidente da } \\
\text { Associação Brasileira de } \\
\text { Ensino Farmacêutico e } \\
\text { Bioquímico }\end{array}$ & $\begin{array}{l}\text { Ensino das Ciências } \\
\text { Farmacêuticas }\end{array}$ \\
\hline & WALDEMIRO DE SOUZA & $\begin{array}{l}\text { Presidente do Centro de } \\
\text { Estudos Afro-Brasileiros }\end{array}$ & $\begin{array}{l}\text { Influência do } \\
\text { colonizador sobre o } \\
\text { negro }\end{array}$ \\
\hline & HÉLIO SANTOS & $\begin{array}{l}\text { Presidente do Conselho } \\
\text { da Comunidade Negra }\end{array}$ & $\begin{array}{l}\text { Discriminação } \\
\text { racial, } \\
\text { infradotados }\end{array}$ \\
\hline & $\begin{array}{l}\text { FRANCISCO ANTÔNIO } \\
\text { POLI }\end{array}$ & $\begin{array}{l}\text { Presidente da União dos } \\
\text { Diretores de Escolas do } \\
\text { Magistério (Udemo) }\end{array}$ & $\begin{array}{l}\text { Verbas públicas, } \\
\text { provimento de } \\
\text { cargo dos diretores } \\
\text { de escola }\end{array}$ \\
\hline & $\begin{array}{l}\text { MARIA DE LOURDES } \\
\text { TEODORO }\end{array}$ & Professora da UnB & Discriminação racial \\
\hline & LAÍS ADERNE & $\begin{array}{ll}\text { Representante } & \text { da } \\
\text { Comissão Pró-Federação } \\
\text { Nacional de Arte- } \\
\text { Educadores }\end{array}$ & Arte-educador \\
\hline & MARY YCLEA & $\begin{array}{l}\text { Presidente da Associação } \\
\text { Nacional dos Professores } \\
\text { de Prática de Trabalho }\end{array}$ & $\begin{array}{l}\text { Educação integral e } \\
\text { prática de trabalho }\end{array}$ \\
\hline & GUNTOLF VAN KAICK & $\begin{array}{l}\text { Vice-presidente da } \\
\text { Organização } \\
\text { Cooperativas Brasileiras }\end{array}$ & $\begin{array}{l}\text { Ensino } \\
\text { cooperativista }\end{array}$ \\
\hline
\end{tabular}




\begin{tabular}{|c|c|c|c|c|}
\hline & \multicolumn{2}{|c|}{ ULISSES PANISSET } & $\begin{array}{l}\text { Professor e representante } \\
\text { da Associação Educativa } \\
\text { Evangélica }\end{array}$ & Escolas particulares \\
\hline $\begin{array}{c}\mathbf{2 5}^{\mathrm{a}}(\mathbf{6}) \\
13 / 5 / 1987\end{array}$ & $\begin{array}{l}\text { JORGE } \\
\text { BORNHAUSEN }\end{array}$ & KONDER & Ministro da Educação & $\begin{array}{ll}\text { Política } & \text { de } \\
\text { educação } & \end{array}$ \\
\hline \multirow[b]{2}{*}{$\begin{array}{c}30^{\mathrm{a}}(7) \\
\text { (Especial) } \\
18 / 5 / 1987\end{array}$} & $\begin{array}{l}\text { PROFESSOR } \\
\text { GADOTTI }\end{array}$ & MOACIR & Educador & $\begin{array}{l}\text { Lastro social da } \\
\text { nova Carta; criação } \\
\text { de sistema nacional } \\
\text { de escola pública; } \\
\text { fim do } \\
\text { analfabetismo }\end{array}$ \\
\hline & $\begin{array}{l}\text { PROFESSOR } \\
\text { FREIRE }\end{array}$ & PAULO & Educador & $\begin{array}{lr}\text { Alfabetização } & \text { e } \\
\text { escola } & \text { pública; } \\
\text { formação } & \\
\text { competente } & \text { e } \\
\text { permanente } & \text { do } \\
\text { educador; } & \text { revisão } \\
\text { das } & \text { escolas } \\
\text { normais } & \\
\end{array}$ \\
\hline $\begin{array}{c}32^{\mathrm{a}}(\mathbf{8}) \\
20 / 5 / 1987\end{array}$ & $\begin{array}{l}\text { PROFESSOR } \\
\text { TEDESCO }\end{array}$ & JUAN & $\begin{array}{l}\text { Diretor da Unesco para a } \\
\text { América Latina }\end{array}$ & $\begin{array}{l}\text { Fim do } \\
\text { analfabetismo, } \\
\text { escolaridade } \\
\text { obrigatória e mais } \\
\text { qualidade do ensino }\end{array}$ \\
\hline
\end{tabular}


ANEXO L - CRONOLOGIA DAS REUNIÕES DA COMISSÃO DE SISTEMATIZAÇÃO ${ }^{82}$

\begin{tabular}{|c|c|c|c|}
\hline Reunião & Data & Objeto & $\begin{array}{l}\text { Diário da } \\
\text { ANC }\end{array}$ \\
\hline & 9/4/1987 & Instalação & $\frac{\frac{8 / 5 / 1987}{\text { Supl. } 56 \mathrm{p}}}{\underline{169}}$ \\
\hline 1a ORD. & $24 / 4 / 1987$ & Programação das atividades; sistema de governo & $\frac{\frac{8 / 5 / 1987}{\text { Supl. } 56 \mathrm{p}}}{\underline{177}}$ \\
\hline $1^{\underline{a}}$ EXT. & $28 / 4 / 1987$ & Informal & $\frac{20 / 5 / 1987}{\frac{\text { Supl. } 62 \mathrm{p}}{\underline{231}}}$ \\
\hline $2^{\mathrm{a}} \mathrm{ORD}$ & $7 / 5 / 1987$ & $\begin{array}{l}\text { Distribuição do resumo da correspondência e cópia do } \\
\text { Parecer do Relator sobre o Regimento Interno }\end{array}$ & $\frac{21 / 5 / 1987}{\underline{\text { Supl. } 63 \mathrm{p}}}$ \\
\hline $2^{\mathrm{a}}$ EXT. & $12 / 5 / 1987$ & $\begin{array}{l}\text { Apreciação do Projeto de Decisão nº 1/87, do Const. } \\
\text { Hermes Zaneti }\end{array}$ & $\frac{27 / 5 / 1987}{\underline{\text { Supl. } 66 \mathrm{p} .}}$ \\
\hline $3^{\mathrm{a}}$ ORD. & $14 / 5 / 1987$ & Parecer sobre o Projeto de Decisão no 1/87 & $\frac{17 / 6 / 1987}{\frac{\text { Supl. } 78 p}{\underline{179}}}$ \\
\hline $3^{a}$ EXT. & $18 / 5 / 1987$ & $\begin{array}{l}\text { Parecer sobre o Projeto de Decisão n 2/87, do Const. } \\
\text { Victor Faccioni }\end{array}$ & $\frac{18 / 6 / 1987}{\frac{\text { Supl. } 79 \mathrm{p}}{172}}$ \\
\hline $4^{\mathrm{a}} \mathrm{ORD}$ & $21 / 5 / 1987$ & $\begin{array}{l}\text { Apreciação do Substitutivo do Relator, ao Projeto de } \\
\text { Resolução nํ1/87, do Const. Antonio Carlos Konder } \\
\text { Reis }\end{array}$ & $\frac{19 / 6 / 1987}{\underline{\text { Supl. } 80 \mathrm{p}}}$ \\
\hline \multirow[t]{2}{*}{ 5a ORD. } & $26 / 5 / 1987$ & $\begin{array}{l}\text { 1. Projeto de Decisão } n^{0} \text { 3/87, do Const. Brandão } \\
\text { Monteiro. 2. Apreciação do Substitutivo do Relator ao } \\
\text { Projeto de Resolução no } 1 / 87 \text {. Não houve votação por } \\
\text { falta de quorum }\end{array}$ & $\frac{\underline{20 / 6 / 1987}}{\underline{\text { Supl. } 81 \mathrm{p}}}$ \\
\hline & $28 / 5 / 1987$ & Termo de Reunião & $\frac{20 / 6 / 1987}{\underline{\text { Supl. } 81 \mathrm{p} .}}$ \\
\hline 6- ORD. & 2/6/1987 & $\begin{array}{l}\text { Votação do Projeto de Resolução no } 1 / 87 \text { (Substitutivo } \\
\text { e Emendas) }\end{array}$ & $\frac{16 / 7 / 1987}{\frac{\text { Supl. } 95 \mathrm{p}}{\underline{222}}}$ \\
\hline $7^{\mathrm{a}} \mathrm{ORD}$. & $4 / 6 / 1987$ & $\begin{array}{l}\text { Projeto de Resolução no 1/87. Votação dos destaques } \\
\text { requeridos pelos Constituintes: 1- Ademir Andrade, 2- } \\
\text { Gerson Peres. Const. Raimundo Bezerra apresentou }\end{array}$ & $\frac{4 / 8 / 1987}{\text { Supl. } 114}$ \\
\hline
\end{tabular}

82 Elaborada a partir de quadros disponíveis em: $<$ http://www2.camara.leg.br/atividadelegislativa/legislacao/Constituicoes Brasileiras/constituicao-cidada/o-processo-constituinte $>$. Acesso em: 25 nov. 2014. ETAPAS/FASES - I: Anteprojeto de Constituição; J/K: Emendas de Mérito e de Adequação ao Anteprojeto; L: Projeto de Constituição; M: Emendas (1P) de Plenário e Populares; N: Substitutivo 1 do Relator; O: Emenda (ES) ao Substitutivo 1; P: Substitutivo 2 do Relator. 


\begin{tabular}{|c|c|c|c|}
\hline & & $\begin{array}{l}\text { requerimento, oralmente, convidando Sr. Ministro } \\
\text { Bresser Pereira, que foi aprovado }\end{array}$ & p. 234 \\
\hline & 9/6/1987 & Termo de Reunião & $\frac{\frac{4 / 8 / 1987}{\text { Supl. } 114}}{\text { p. } 244}$ \\
\hline 8a ORD. & $10 / 6 / 1987$ & $\begin{array}{l}\text { Votação destaque ao art. } 13 \text { do Projeto } 1 / 87 \text {, foi } \\
\text { rejeitado. Votação final do Projeto de Resolução } 1 / 87 \text {, } \\
\text { foi aprovado }\end{array}$ & $\frac{\frac{4 / 8 / 1987}{\text { Supl. } 114}}{\text { p. } 244}$ \\
\hline 4를. EXT. & 28/6/1987 & Discussão do Anteprojeto do Relator & $\frac{5 / 8 / 1987}{\frac{\text { Supl. } 115}{\text { p. } 226}}$ \\
\hline $5^{\mathrm{a}}$ EXT. & 29/6/1987 & Debate do Anteprojeto & $\frac{5 / 8 / 1987}{\frac{\text { Supl. } 115}{\text { p. } 238}}$ \\
\hline 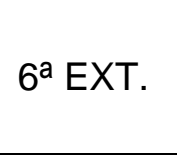 & $30 / 6 / 1987$ & $\begin{array}{l}\text { Debates dos Capítulos III, IV, V e VII do Título XIX do } \\
\text { Anteprojeto do Relator }\end{array}$ & $\frac{\frac{8 / 8 / 1987}{\text { Supl. } 118}}{\text { p. } 191}$ \\
\hline $7^{a} \underline{a}$ EXT. & $1 / 7 / 1987$ & Continuação da discussão do Anteprojeto & $\frac{\frac{8 / 8 / 1987}{\text { Supl. } 118}}{\text { p. } 203}$ \\
\hline 9aㅡ. ORD. & 2/7/1987 & Continuação da discussão do Anteprojeto & $\frac{\frac{8 / 8 / 1987}{\text { Supl. } 118}}{\text { p. } 213}$ \\
\hline $8^{\mathrm{a}} \mathrm{EXT}$. & 9/7/1987 & $\begin{array}{l}\text { Discussão e votação: 1) Projeto de Decisão no } 4 / 87 \text { do } \\
\text { Const. Paulo Ramos; 2) Projeto de Decisão no } 5 / 87 \text { do } \\
\text { Const. Iram Saraiva, deixou de ser apreciado por falta } \\
\text { de quorum }\end{array}$ & $\frac{\frac{8 / 8 / 1987}{\text { Supl. } 118}}{\text { p. } 217}$ \\
\hline 9a EXT. & $10 / 7 / 1987$ & $\begin{array}{l}\text { Continuação da votação dos Projetos de Decisão nºs } \\
4 / 87 \text { e 5/87. Não foram apreciados por falta de quorum }\end{array}$ & $\frac{\frac{8 / 8 / 1987}{\text { Supl. } 118}}{\text { p. } 225}$ \\
\hline 10 $\mathrm{a}$ EXT. & $10 / 7 / 1987$ & $\begin{array}{l}\text { Discussão do Projeto do Relator. Considerando que } \\
\text { não haviam sido distribuídos os avulsos, foi encerrada } \\
\text { a reunião }\end{array}$ & $\frac{\frac{8 / 8 / 1987}{\text { Supl. } 118}}{\text { p. } 234}$ \\
\hline $11^{\mathrm{a}}$ EXT. & $11 / 7 / 1987$ & Discussão e votação do Parecer do Relator & $\frac{\frac{22 / 8 / 1987}{\text { Supl. } 132}}{\text { p. } 438}$ \\
\hline $12^{\mathrm{a}} \mathrm{EXT}$ & $11 / 7 / 1987$ & $\begin{array}{l}\text { Votação do Projeto de Decisão no } 4 / 87 \text {, do Constituinte } \\
\text { Paulo Ramos. Foi aprovado. Votação do Projeto de } \\
\text { Decisão no } 5 / 87 \text {, do Constituinte Iram Saraiva, adiado } \\
\text { por falta de quorum }\end{array}$ & $\frac{\frac{22 / 8 / 1987}{\text { Supl. } 132}}{\text { p. } 456}$ \\
\hline $13^{a}$ EXT. & $13 / 7 / 1987$ & $\begin{array}{l}\text { Votação do Projeto de Decisão no } 5 / 87 \text {, do Constituinte } \\
\text { Iram Saraiva }\end{array}$ & $\frac{\frac{22 / 8 / 1987}{\text { Supl. } 132}}{\text { p. } 461}$ \\
\hline $14^{\mathrm{a}}$ EXT. & $13 / 7 / 1987$ & $\begin{array}{l}\text { Continuação da votação do Projeto de Decisão no } \\
5 / 87 \text {, do Constituinte Iram Saraiva. Havendo sido } \\
\text { constatada a falta de quorum, o Sr. Presidente } \\
\text { encerrou os trabalhos }\end{array}$ & $\frac{\frac{22 / 8 / 1987}{\text { Supl. } 132}}{\text { p. } 472}$ \\
\hline $\begin{array}{l}10^{\mathrm{a}} \\
\text { ORD. }\end{array}$ & 23/7/1987 & $\begin{array}{l}\text { Exame preliminar da proposta de Emenda Popular } n^{0} \\
00004-1 \text {. O Relator deu Parecer favorável e foi }\end{array}$ & $\underline{22 / 8 / 1987}$ \\
\hline
\end{tabular}




\begin{tabular}{|c|c|c|c|}
\hline & & aprovado pelo Plenário & $\frac{\text { Supl. } 132}{\text { p. } 473}$ \\
\hline $\begin{array}{l}11^{\mathrm{a}} \\
\text { ORD. }\end{array}$ & 6/8/1987 & $\begin{array}{l}\text { Discussão e votação dos Projetos de Resolução nos } \\
14 \text { e } 15 / 87 \text {. O Projeto de Resolução no } 15 / 87 \text { foi } \\
\text { retirado de pauta. Adiada a votação por falta de } \\
\text { quorum }\end{array}$ & $\frac{\frac{27 / 1 / 1988}{\text { Supl. "B" }}}{\text { p. } 268}$ \\
\hline \multirow[t]{2}{*}{$15^{\mathrm{a}} \mathrm{EXT}}$. & 7/8/1987 & $\begin{array}{l}\text { Votação do Parecer do Relator ao Projeto de } \\
\text { Resolução no } 14 / 87 \text {. Adiada a votação por falta de } \\
\text { quorum }\end{array}$ & $\frac{\frac{27 / 1 / 1988}{\text { Supl. "B" }}}{\text { p. } 283}$ \\
\hline & $10 / 8 / 1987$ & Termo de Reunião & $\frac{\frac{27 / 1 / 1988}{\text { Supl. "B" }}}{\underline{\text { p. } 286}}$ \\
\hline $\begin{array}{c}12^{\mathrm{a}} \\
\text { ORD. }\end{array}$ & $11 / 8 / 1987$ & $\begin{array}{l}\text { Emendas Populares com Pareceres favoráveis ao } \\
\text { recebimento, sob os no-s 19/87, 20/87, 21/87, 22/87, } \\
23 / 87,24 / 87,25 / 87,26 / 87,27 / 87 \text {. Votação do Projeto } \\
\text { de Decisão no 6/87. Pedido de prorrogação do prazo } \\
\text { para apreciação do Projeto de Resolução no } 15 / 87\end{array}$ & $\frac{\frac{27 / 1 / 1988}{\text { Supl. "B" }}}{\text { p. } 286}$ \\
\hline $\begin{array}{l}13^{\mathrm{a}} \\
\text { ORD. }\end{array}$ & $13 / 8 / 1987$ & $\begin{array}{l}\text { Parecer do Relator pela rejeição do Projeto de Decisão } \\
\text { no 6/87. Parecer do Relator pela rejeição do Projeto de } \\
\text { Resolução no } 15 / 87 \text {. Pareceres do Relator, opinando } \\
\text { favorável ao recebimento das seguintes Propostas de } \\
\text { Emendas Populares no s } 32 / 87,33 / 87,36 / 87,37 / 87 \text {, } \\
\text { 38/87, 39/87, 40/87, 42/87, 43/87. O Sr. Presidente } \\
\text { comunicou terem sido indeferidas as seguintes } \\
\text { Propostas de Emendas Populares: } 28 / 87,30 / 87 \text {, } \\
\text { 31/87, 34/87, 41/87, 44/87. O Sr. Presidente colocou } \\
\text { em votação requerimento de autoria do Constituinte } \\
\text { Carlos Sant' Anna, pedindo encerramento da } \\
\text { discussão do Parecer ao Projeto de Decisão no } 6 / 87\end{array}$ & $\frac{\frac{27 / 1 / 1988}{\text { Supl. "B" }}}{\underline{\text { p. } 311}}$ \\
\hline 16르․ EXT. & $14 / 8 / 1987$ & $\begin{array}{l}\text { Parecer do Relator, opinando pela rejeição ao Projeto } \\
\text { de Resolução no 15/87, do Constituinte Virgílio } \\
\text { Guimarães. Pareceres do Relator, opinando } \\
\text { favoravelmente ao recebimento das seguintes } \\
\text { Propostas de Emendas Populares: 45/87, 49/87, } \\
50 / 87,51 / 87,52 / 87,53 / 87,54 / 87,55 / 87,56 / 87,59 / 87, \\
60 / 87,61 / 87,62 / 87,63 / 87,63 / 87,64 / 87,65 / 87,66 / 87 \text {, } \\
67 / 87,68 / 87,71 / 87,77 / 87,80 / 87,82 / 87, \text { e } 83 / 87 \text {. A } \\
\text { seguir, o Sr. Presidente comunicou que foram } \\
\text { indeferidas as seguintes Propostas de Emendas } \\
\text { Populares: 48/87, 58/87, 69/87, 73/87, 74/87, 75/87, } \\
\text { 76/87, 78/87, 79/87, 81/87. Prosseguindo, o Sr. Const. } \\
\text { Nilson Gibson, fez exposição da matéria, que concluiu } \\
\text { opinando contrariamente à aprovação do Projeto de } \\
\text { Resolução no } 15 / 87 \text {. Encerrada a discussão por falta } \\
\text { de quorum }\end{array}$ & $\frac{\frac{27 / 1 / 1988}{\text { Supl. "B" }}}{\text { p. } 324}$ \\
\hline 17 ${ }^{\mathrm{a}}$ EXT. & $17 / 8 / 1987$ & $\begin{array}{l}\text { O Sr. Presidente anunciou a pauta, que constou da } \\
\text { apresentação de Emendas Populares. Comunicou que } \\
\text { foram indeferidas as seguintes Propostas de Emendas } \\
\text { Populares: } 90 / 87,94 / 87,97 / 87,99 / 87,103 / 87,104 / 87 \text {, } \\
\text { 106/87, 107/87, 108/87, 109/87, 112/87, 112/87, } \\
\text { 120/87 e } 129 / 87 \text { e foram aprovados unanimemente as } \\
\text { seguintes Propostas de Emendas Populares: } 29 / 87 \text {, } \\
46 / 87,57 / 87,72 / 87,84 / 87,85 / 87,86 / 87,88 / 87,89 / 87 \text {, }\end{array}$ & $\frac{\frac{27 / 1 / 1988}{\text { Supl. "B" }}}{\underline{\text { p. } 330}}$ \\
\hline
\end{tabular}




\begin{tabular}{|c|c|c|c|}
\hline & & $\begin{array}{l}\text { 91/87, 93/87, 95/87, 96/87, 98/87, 100/87, 101/87, } \\
\text { 102/87, 105/87, 110/87, 111/87, 113/87, 115/87, } \\
\text { 116/87, 117/87, 118/87, 119/87 e 122/87. Como último } \\
\text { item da pauta, constou o Projeto de Resolução } n^{0} \\
\text { 157/87, que deixou de ser apreciada por falta de } \\
\text { quorum }\end{array}$ & \\
\hline $18^{\mathrm{a}} \mathrm{EXT}$. & $22 / 8 / 1987$ & $\begin{array}{l}\text { Discussão e votação dos Projetos de Decisão } n^{\circ}{ }^{\circ} 7 / 87 \\
\text { e } 8 / 87 \text {. Encerrada a discussão por falta de quorum }\end{array}$ & $\frac{\frac{27 / 1 / 1988}{\text { Supl. "B" }}}{\text { p. } 335}$ \\
\hline 19a EXT. & 24/8/1987 & $\begin{array}{l}\text { Votação do Projeto de Decisão no } 7 / 87 \text {, do Sr. Const. } \\
\text { Brandão Monteiro. Por falta de quorum o Projeto } \\
\text { deixou de ser apreciado. Leitura do Parecer do Projeto } \\
\text { de Decisão no } 8 / 87\end{array}$ & $\frac{\frac{27 / 1 / 1988}{\text { Supl. "B" }}}{\text { p. } 341}$ \\
\hline 20르. EXT. & $26 / 8 / 1987$ & $\begin{array}{l}\text { Audiência Pública } \\
\text { Assuntos: Direitos da mulher / Aposentadoria / Saúde } \\
\text { da mulher / Direitos da família / Aposentadoria donas } \\
\text { de casa }\end{array}$ & $\frac{\frac{27 / 1 / 1988}{\text { Supl. "B" }}}{\text { p. } 354}$ \\
\hline $\begin{array}{l}14^{a} \\
\text { ORD. }\end{array}$ & 27/8/1987 & $\begin{array}{l}\text { Audiência Pública } \\
\text { Assuntos: Direitos do trabalhador / Aposentadoria do } \\
\text { trabalhador / Aposentadoria do trabalhador rural / } \\
\text { Direitos e garantias dos pensionistas e aposentados / } \\
\text { Proventos de aposentadoria / Imposto de renda sobre } \\
\text { salários / Estabilidade no emprego / Aposentadoria } \\
\text { bancários / Estabilidade para servidores públicos } \\
\text { celetistas / Participação nos lucros / Reforma urbana / } \\
\text { Transporte coletivo / Moradia popular }\end{array}$ & $\frac{\frac{27 / 1 / 1988}{\text { Supl. "B" }}}{\text { p. } 369}$ \\
\hline $21^{\mathrm{a}}$ EXT. & 28/8/1987 & $\begin{array}{l}\text { Audiência Pública } \\
\text { Assuntos: Saúde pública / Sistema nacional de saúde / } \\
\text { Salário mínimo para deficientes / Direitos dos } \\
\text { deficientes / Previdência privada / Plano de } \\
\text { previdência das Estatais e Parlamentar }\end{array}$ & $\frac{\frac{27 / 1 / 1988}{\text { Supl. "B" }}}{\underline{\text { p. } 408}}$ \\
\hline 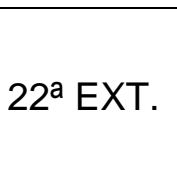 & $31 / 8 / 1987$ & $\begin{array}{l}\text { Audiência Pública } \\
\text { Assuntos: Forças Armadas / Supremo Tribunal Federal } \\
\text { / Juizado de instrução / Polícia Rodoviária Federal / } \\
\text { Desarmamento nuclear / Mediunidade }\end{array}$ & $\frac{\frac{27 / 1 / 1988}{\text { Supl. "B" }}}{\underline{\text { p. } 426}}$ \\
\hline $\begin{array}{l}15^{\mathrm{a}} \\
\text { ORD. }\end{array}$ & $1 / 9 / 1987$ & $\begin{array}{l}\text { Audiência Pública } \\
\text { Assuntos: Participação popular / Voto proporcional / } \\
\text { Plebiscito sobre o regime de governo / Diretas já / } \\
\text { Assistência espiritual / Divisão territorial da Bahia / } \\
\text { Criação do Estado de Santa Cruz / Criação do Estado } \\
\text { do lguaçu / Criação do Estado de Tocantins / Criação } \\
\text { do Estado de São Francisco / Criação do Estado do } \\
\text { Triângulo / Competência estadual para legislar sobre } \\
\text { criação de Municípios }\end{array}$ & $\frac{\frac{27 / 1 / 1988}{\text { Supl. "B" }}}{\text { p. 439 }}$ \\
\hline $\begin{array}{l}16^{\mathrm{a}} \\
\text { ORD. }\end{array}$ & 2/9/1987 & $\begin{array}{l}\text { Audiência Pública } \\
\text { Assuntos: Direitos da criança e do adolescente / } \\
\text { Educação / Ensino público gratuito / Ensino religioso / } \\
\text { Liberdade religiosa / Preservação do SESI, SENAI, } \\
\text { SESC, SENAC / Formação mão-de-obra profissional / } \\
\text { Intermediação de mão-de-obra }\end{array}$ & $\frac{\frac{27 / 1 / 1988}{\text { Supl. "B" }}}{\underline{\text { p. } 478}}$ \\
\hline $\begin{array}{l}17^{\mathrm{a}} \\
\text { ORD. }\end{array}$ & 3/9/1987 & $\begin{array}{l}\text { Audiência Pública } \\
\text { Assuntos: Monopólio estatal do petróleo / Reforma } \\
\text { agrária / Ordem econômica e social / Livre iniciativa / } \\
\text { Dívida externa / Consumidor / Abastecimento / }\end{array}$ & $\frac{\frac{27 / 1 / 1988}{\text { Supl. "B" }}}{\underline{\text { p. } 513}}$ \\
\hline
\end{tabular}




\begin{tabular}{|c|c|c|c|}
\hline & & $\begin{array}{l}\text { Cooperativismo / Planejamento regional / Imposto } \\
\text { único sobre minerais }\end{array}$ & \\
\hline 23른. & 4/9/1987 & $\begin{array}{l}\text { Audiência Pública } \\
\text { Assuntos: Fixação de datas para eleição presidencial / } \\
\text { Monopólio estatal das telecomunicações / } \\
\text { Democratização dos meios de comunicação / Censura } \\
\text { / Populações indígenas / Nações indígenas }\end{array}$ & $\frac{\frac{27 / 1 / 1988}{\text { Supl. "B" }}}{\underline{\text { p. } 557}}$ \\
\hline 24르 EXT. & 8/9/1987 & $\begin{array}{l}\text { Informação sobre o calendário destinado à fase de } \\
\text { discussão do Substitutivo, apresentado pelo Sr. } \\
\text { Relator }\end{array}$ & $\frac{27 / 1 / 1988}{\frac{\text { Supl. "B" }}{\text { p. } 580}}$ \\
\hline $\begin{array}{r}18^{\underline{a}} \\
\text { ORD. }\end{array}$ & 9/9/1987 & $\begin{array}{l}\text { Continuação da discussão do Substitutivo do Sr. } \\
\text { Relator }\end{array}$ & $\frac{\frac{27 / 1 / 1988}{\text { Supl. "B" }}}{\text { p. } 591}$ \\
\hline \multirow[t]{2}{*}{$25^{\mathrm{a}} \mathrm{EXT}}$. & $10 / 9 / 1987$ & $\begin{array}{l}\text { Continuação da discussão do Substitutivo do Sr. } \\
\text { Relator }\end{array}$ & $\frac{\frac{27 / 1 / 1988}{\text { Supl. "B" }}}{\text { p. } 601}$ \\
\hline & $11 / 9 / 1987$ & Termo de Reunião & $\frac{\frac{27 / 1 / 1988}{\text { Supl. "B" }}}{\text { p. } 618}$ \\
\hline \multirow[t]{2}{*}{ 26믈. } & $14 / 9 / 1987$ & $\begin{array}{l}\text { Continuação da discussão do } 1 \text { o Substitutivo do Sr. } \\
\text { Relator }\end{array}$ & $\frac{\frac{27 / 1 / 1988}{\text { Supl. "B" }}}{\text { p. } 619}$ \\
\hline & $15 / 9 / 1987$ & Termo de Reunião & $\frac{\frac{27 / 1 / 1988}{\text { Supl. "B" }}}{\underline{\text { p. } 625}}$ \\
\hline 27르. EXT. & $15 / 9 / 1987$ & $\begin{array}{l}\text { Continuação da discussão do } 1 \text { 으 Substitutivo do Sr. } \\
\text { Relator }\end{array}$ & $\frac{\frac{27 / 1 / 1988}{\text { Supl. "B" }}}{\text { p. } 625}$ \\
\hline $\begin{array}{l}19^{\mathrm{a}} \\
\text { ORD. }\end{array}$ & $16 / 9 / 1987$ & $\begin{array}{l}\text { Continuação da discussão do } 1 \text { 으 Substitutivo do Sr. } \\
\text { Relator }\end{array}$ & $\frac{\frac{27 / 1 / 1988}{\text { Supl. "B" }}}{\text { p. } 642}$ \\
\hline $\begin{array}{l}20^{\mathrm{a}} \\
\text { ORD. }\end{array}$ & $17 / 9 / 1987$ & $\begin{array}{l}\text { Continuação da discussão do } 1 \text { 으 Substitutivo do Sr. } \\
\text { Relator }\end{array}$ & $\frac{27 / 1 / 1988}{\frac{\text { Supl. "B" }}{\text { p. } 665}}$ \\
\hline 28aㅡ EXT. & $18 / 9 / 1987$ & $\begin{array}{l}\text { Continuação da discussão do } 1 \text { - Substitutivo do Sr. } \\
\text { Relator }\end{array}$ & $\frac{\frac{27 / 1 / 1988}{\text { Supl. "B" }}}{\text { p. } 700}$ \\
\hline 29a EXT. & 19/9/1987 & $\begin{array}{l}\text { Continuação da discussão do } 1^{\circ} \text { Substitutivo do Sr. } \\
\text { Relator }\end{array}$ & $\frac{27 / 1 / 1988}{\frac{\text { Supl. "B" }}{\text { p. } 713}}$ \\
\hline 30 $\mathrm{a}$ EXT. & 20/9/1987 & $\begin{array}{l}\text { Continuação da discussão do } 1^{\circ} \text { Substitutivo do Sr. } \\
\text { Relator }\end{array}$ & $\frac{\frac{27 / 1 / 1988}{\text { Supl. "B" }}}{\text { p. } 730}$ \\
\hline 31 ${ }^{\mathrm{a}}$ EXT. & $21 / 9 / 1987$ & $\begin{array}{l}\text { Continuação da discussão do } 1^{\circ} \text { Substitutivo do Sr. } \\
\text { Relator }\end{array}$ & $\frac{\frac{27 / 1 / 1988}{\text { Supl. "B" }}}{\underline{\text { p. } 746}}$ \\
\hline $\begin{array}{l}21^{a} \\
\text { ORD. }\end{array}$ & 22/9/1987 & $\begin{array}{l}\text { Continuação da discussão do } 1^{\circ} \text { Substitutivo do Sr. } \\
\text { Relator }\end{array}$ & $\frac{27 / 1 / 1988}{\text { Supl. "B" }}$ \\
\hline
\end{tabular}




\begin{tabular}{|c|c|c|c|}
\hline & & & p. 756 \\
\hline $\begin{array}{l}22^{\underline{a}} \\
\text { ORD }\end{array}$ & 23/9/1987 & $\begin{array}{l}\text { O Presidente anuncia ao Plenário que a votação do } 1^{\circ} \\
\text { Substitutivo será dia } 24 / 9 / 1987\end{array}$ & $\frac{\frac{27 / 1 / 1988}{\text { Supl. "B" }}}{\text { p. } 784}$ \\
\hline $32^{a}$ EXT. & 24/9/1987 & Votação & $\frac{\frac{27 / 1 / 1988}{\text { Supl. "C" }}}{\text { p. } 812}$ \\
\hline
\end{tabular}


ANEXO M - PAINÉIS DE TRAMITAÇÃO DA ASSEMBLÉIA NACIONAL CONSTITUINTE (1987-1988)

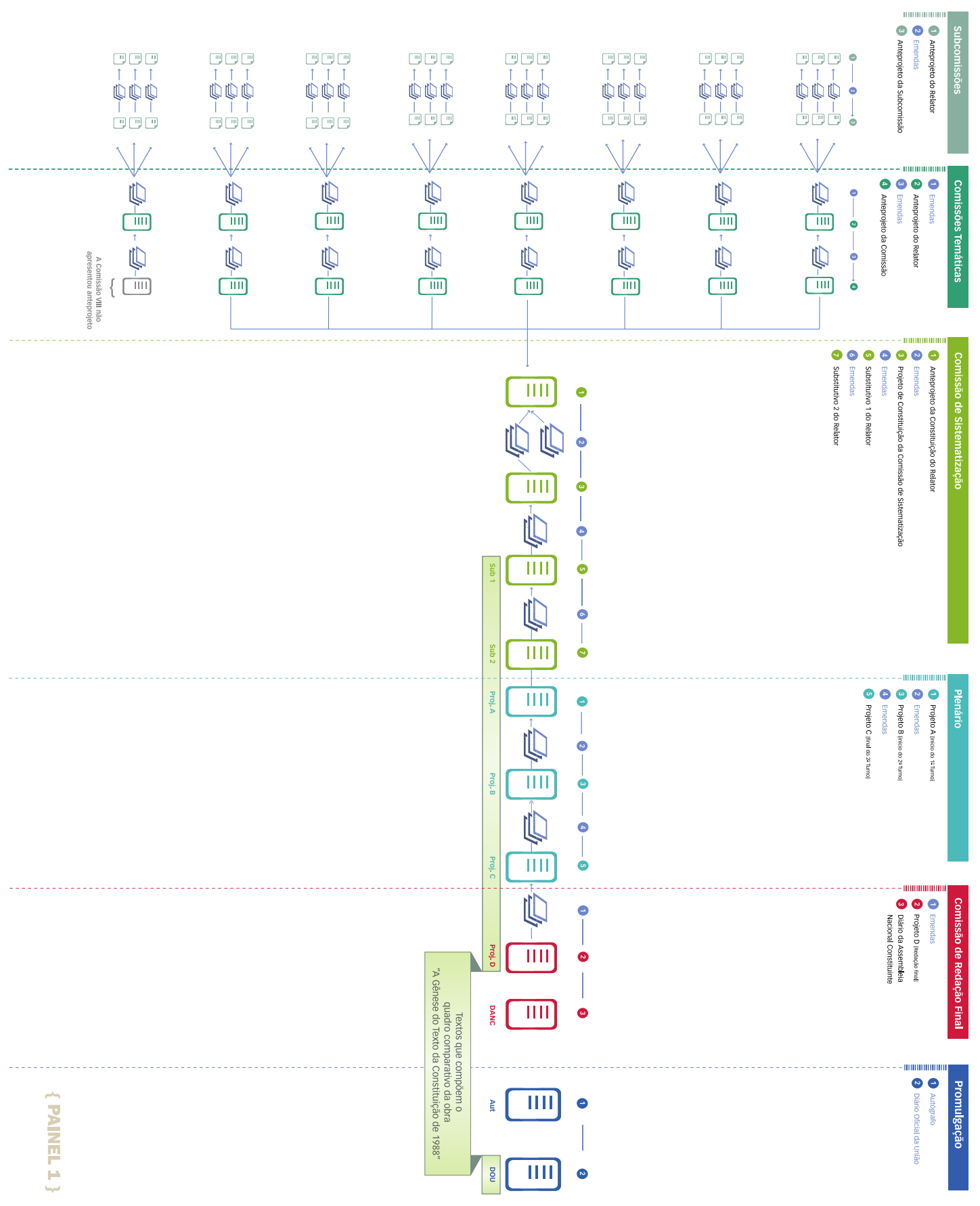




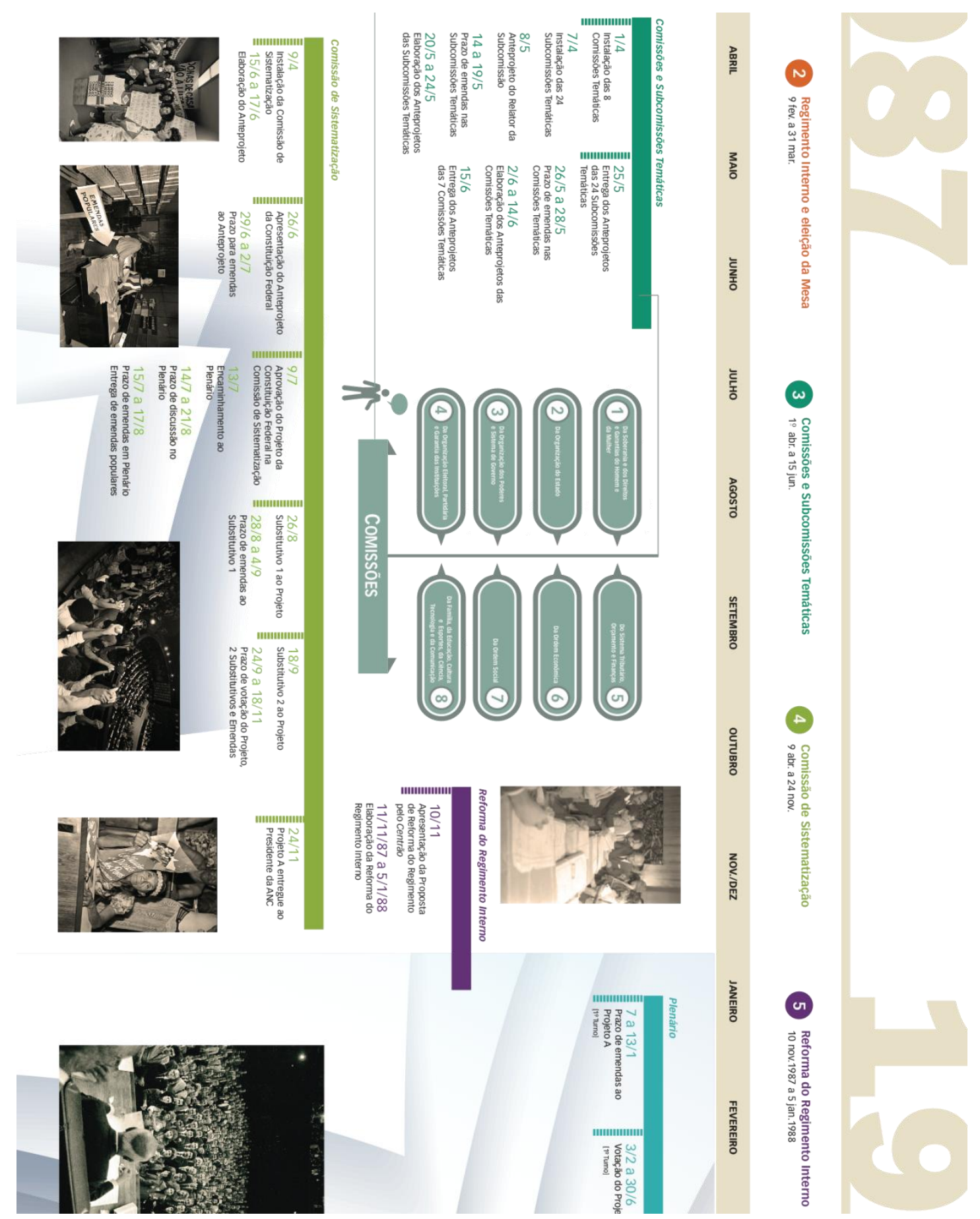




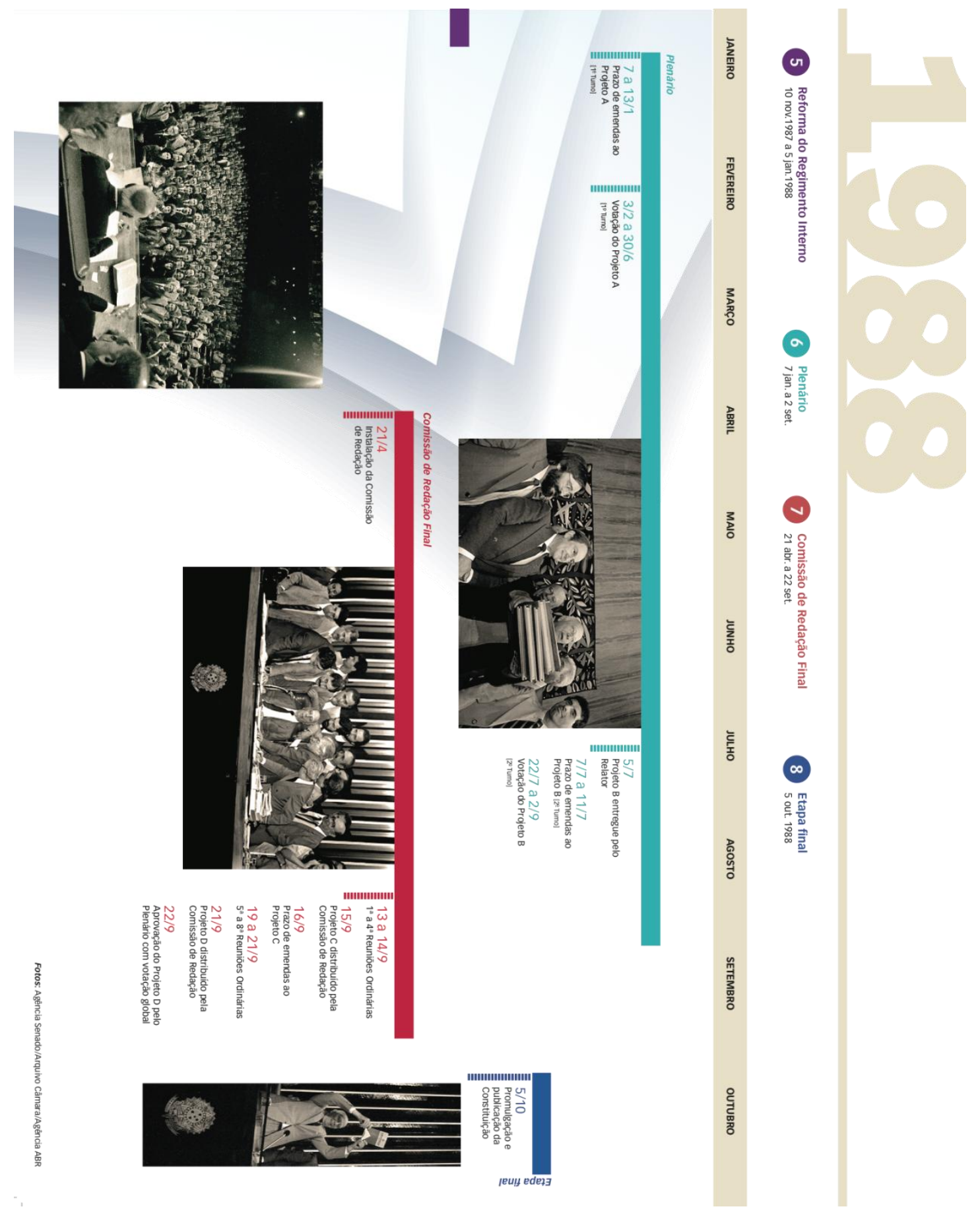




\section{ANEXO N - QUADROS DE TRAMITACÃO DA ASSEMBLEIA NACIONAL CONSTITUINTE (1987-1988)}
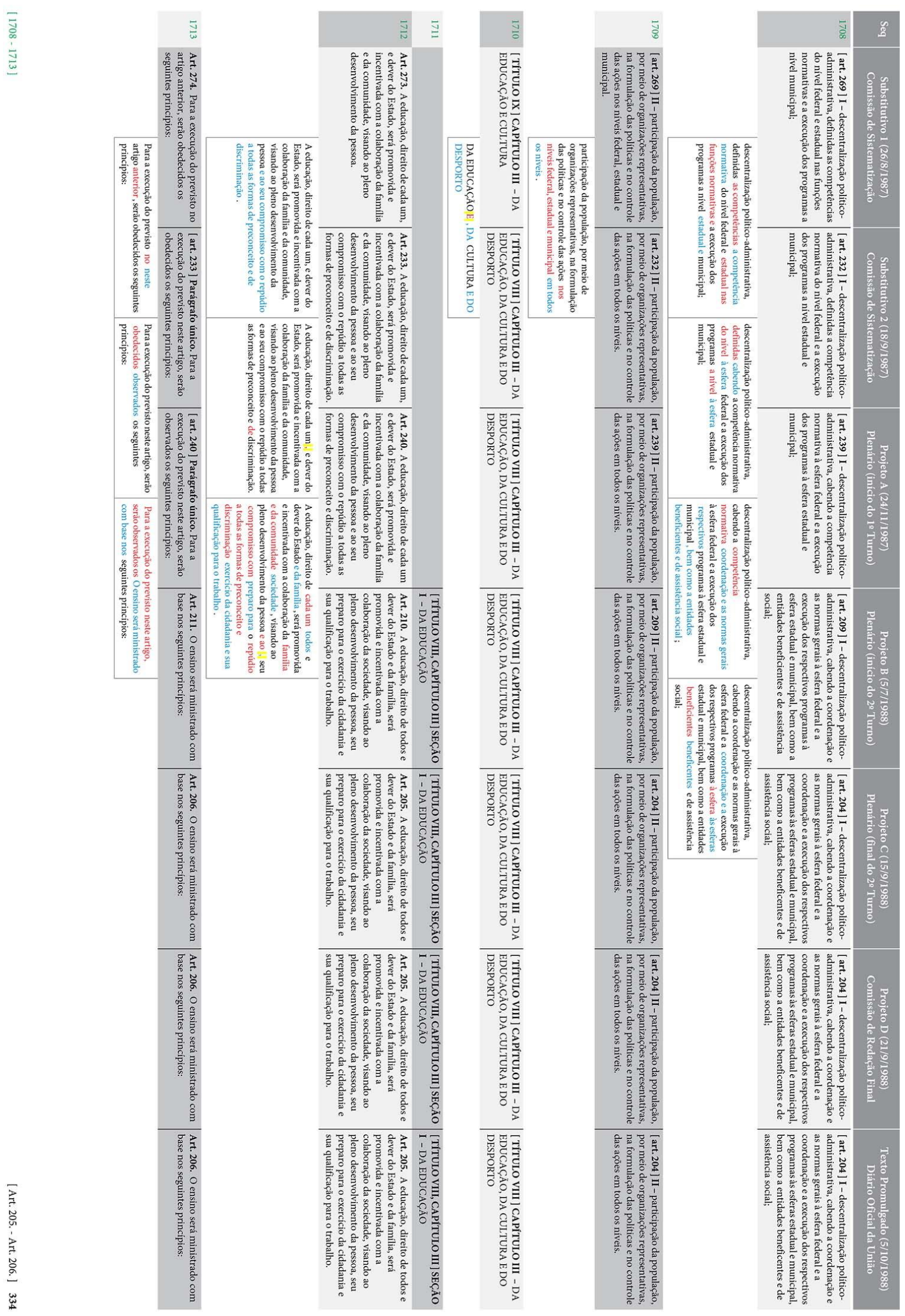


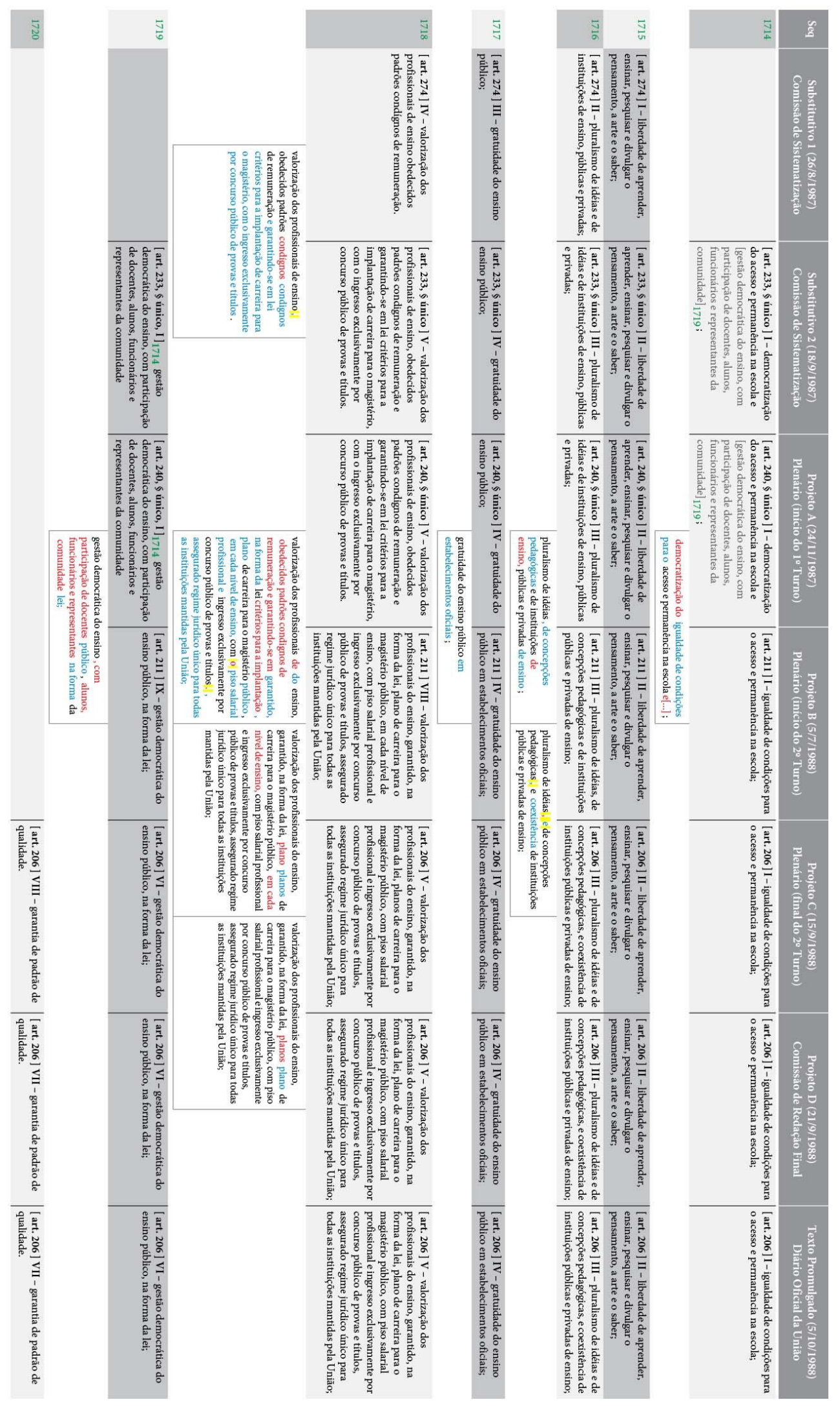




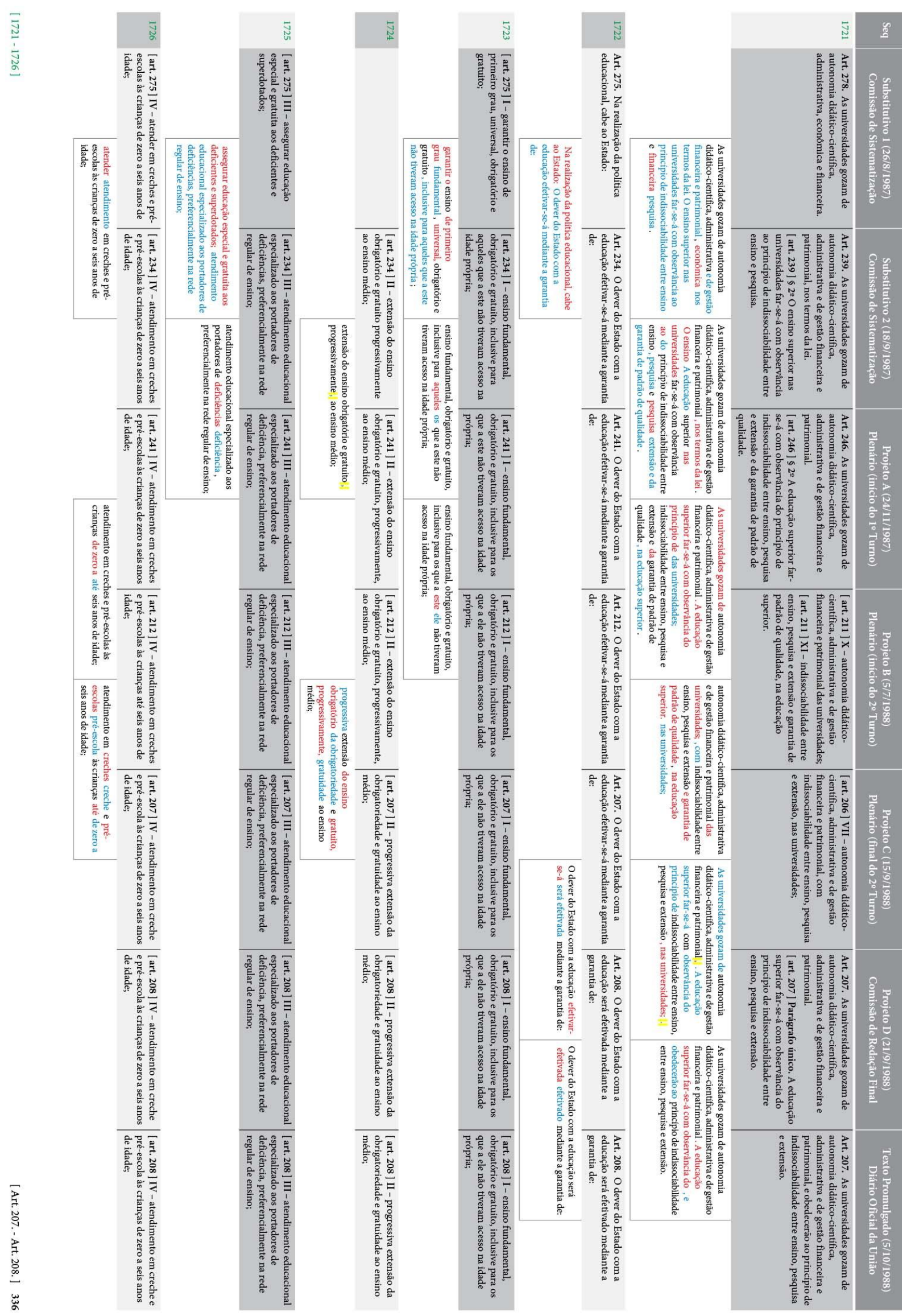




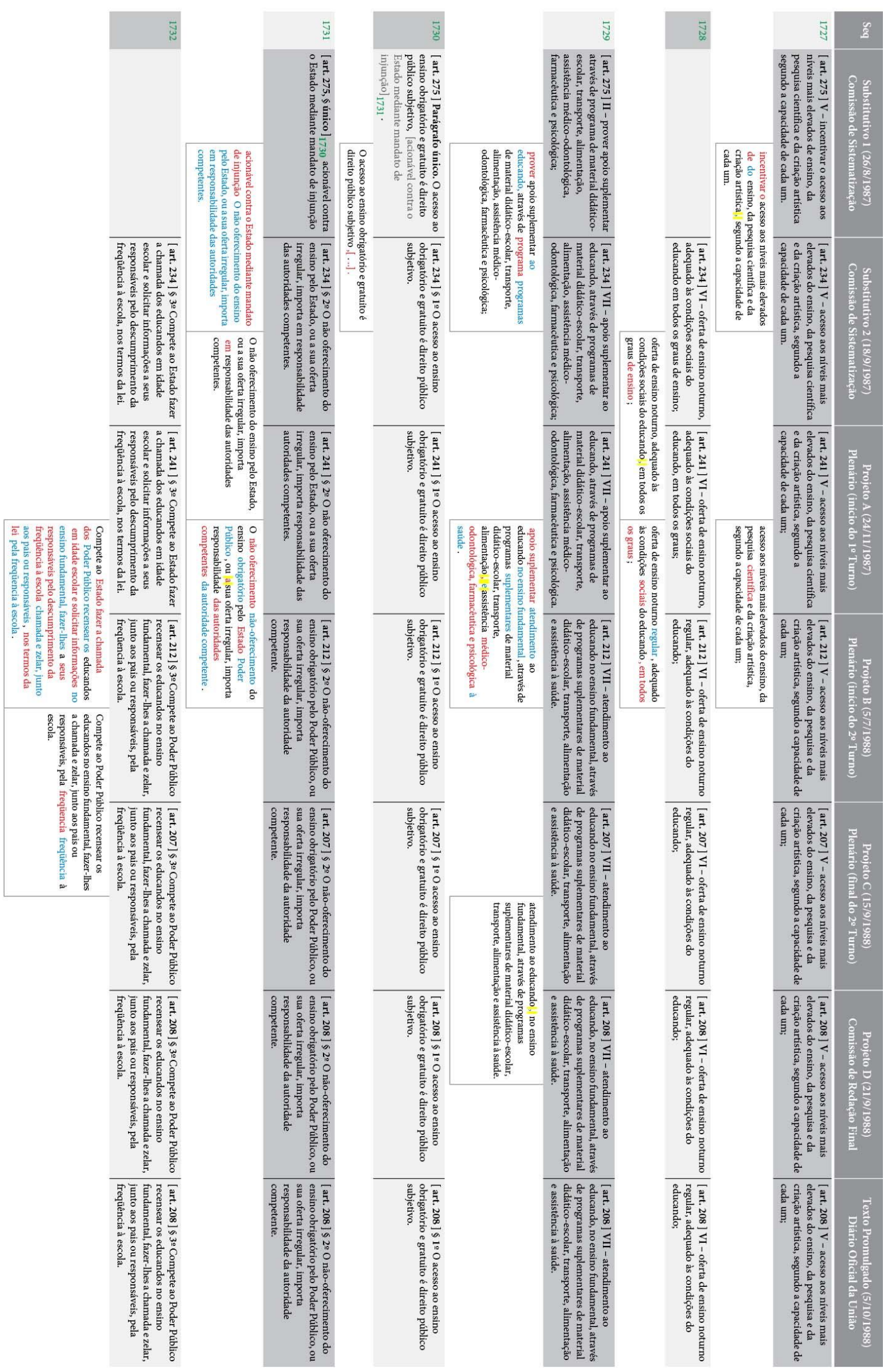




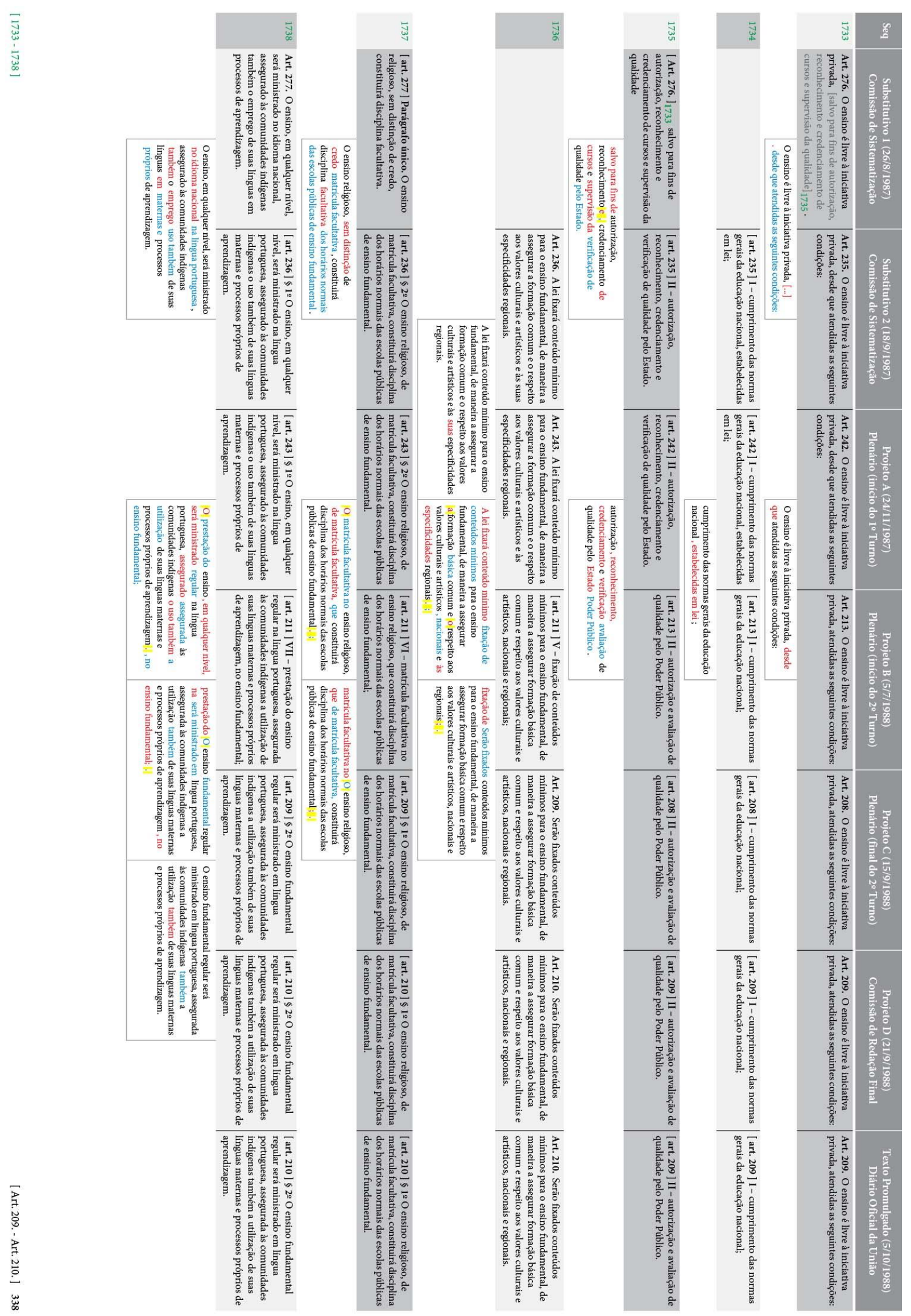




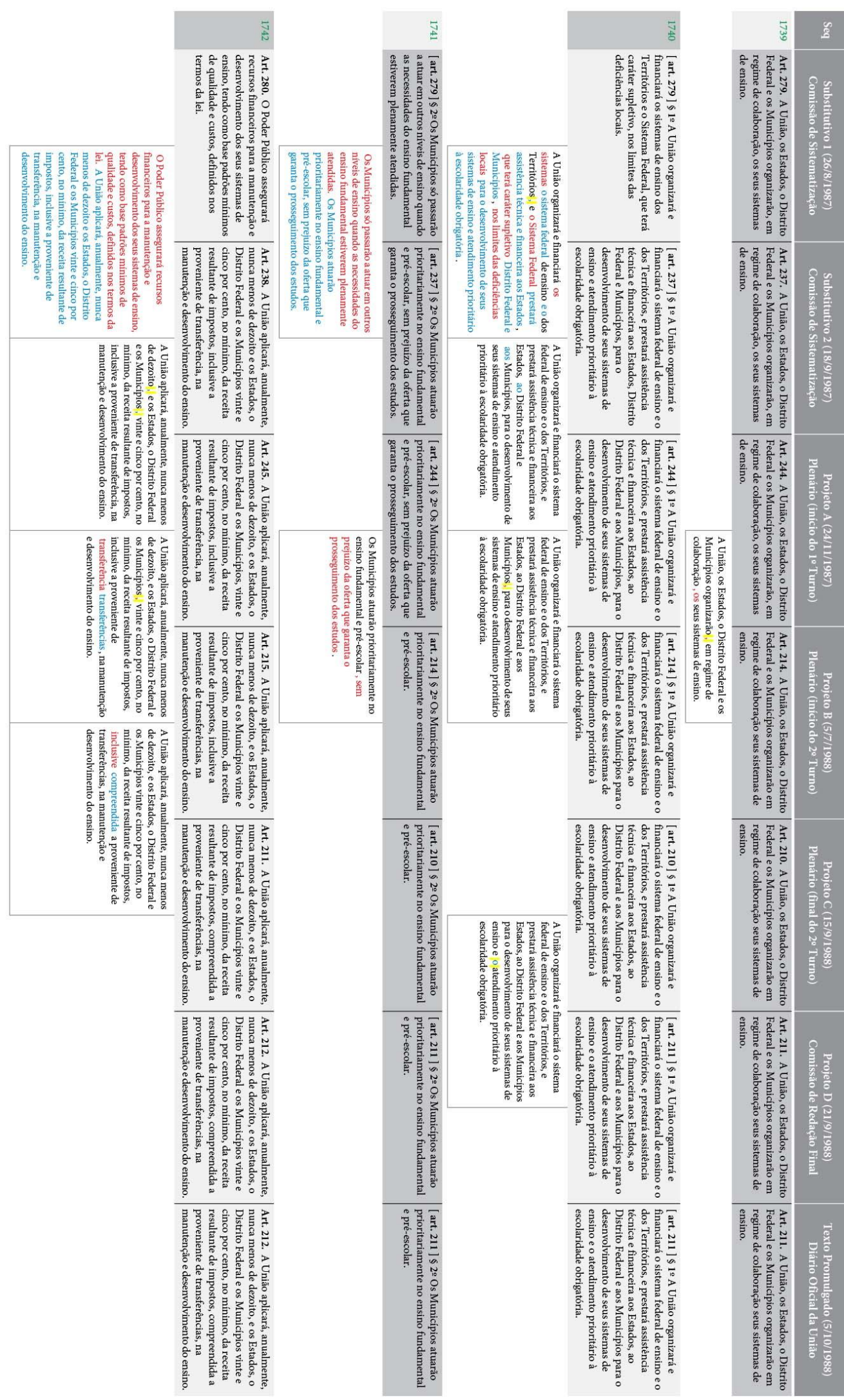




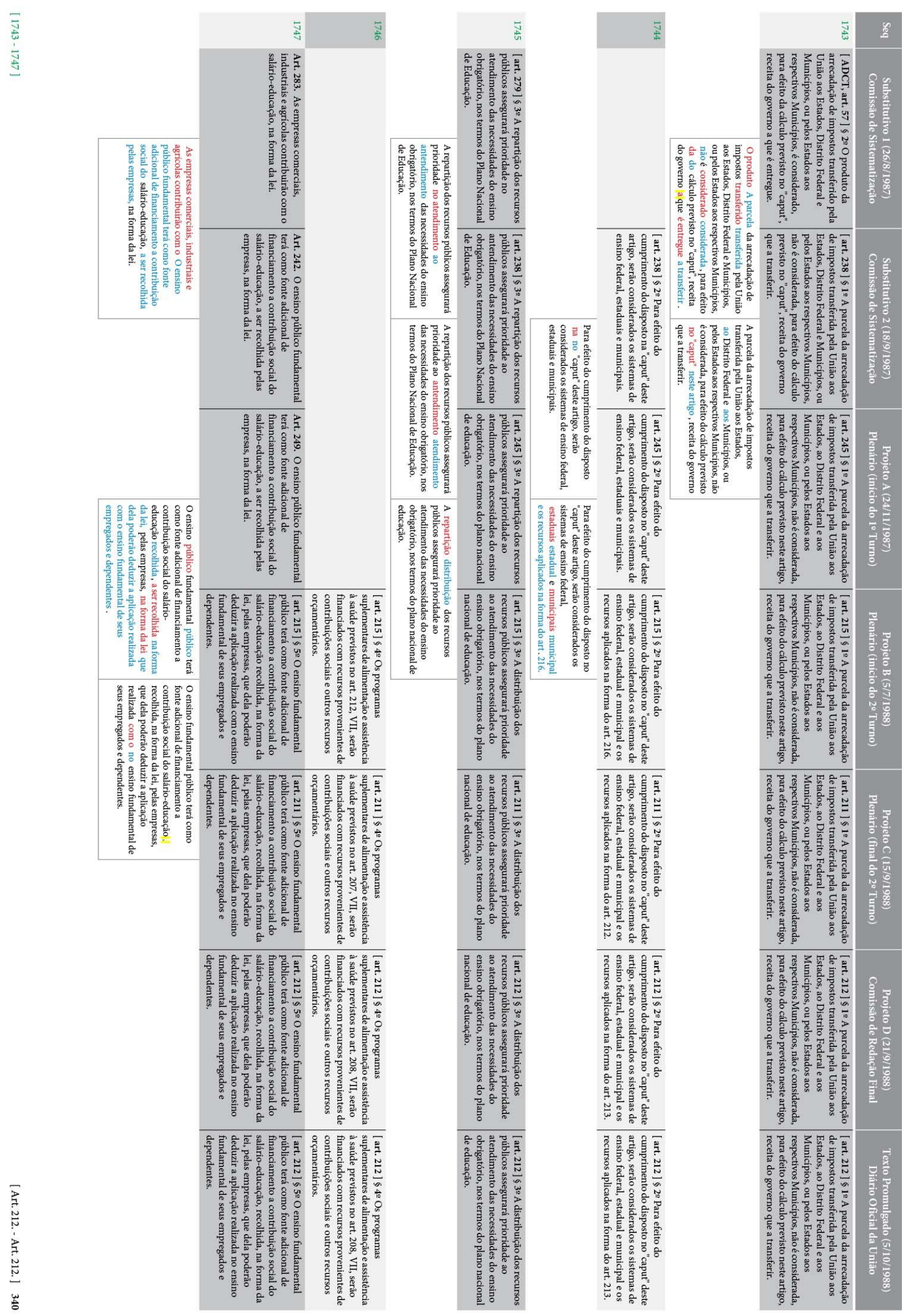




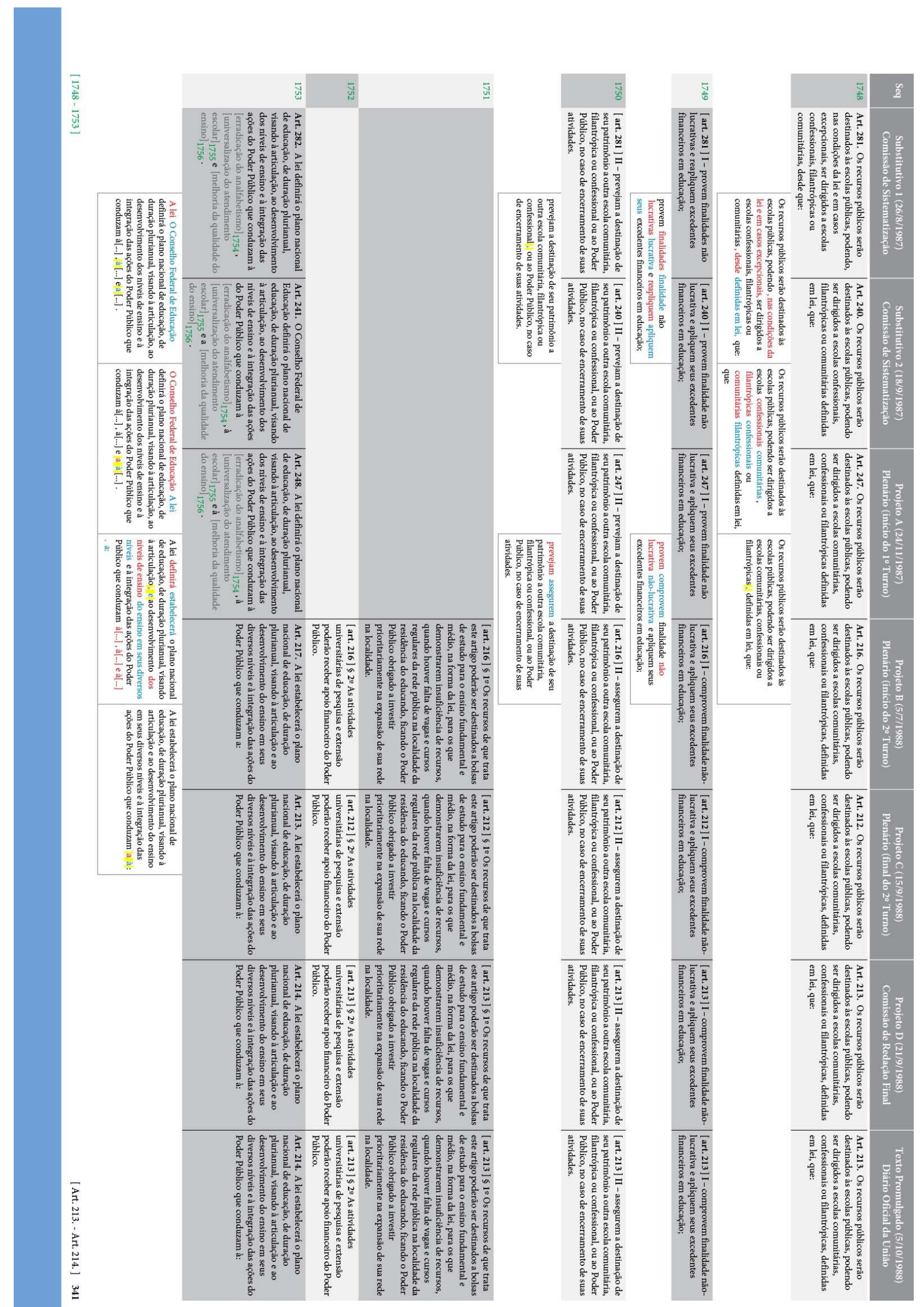




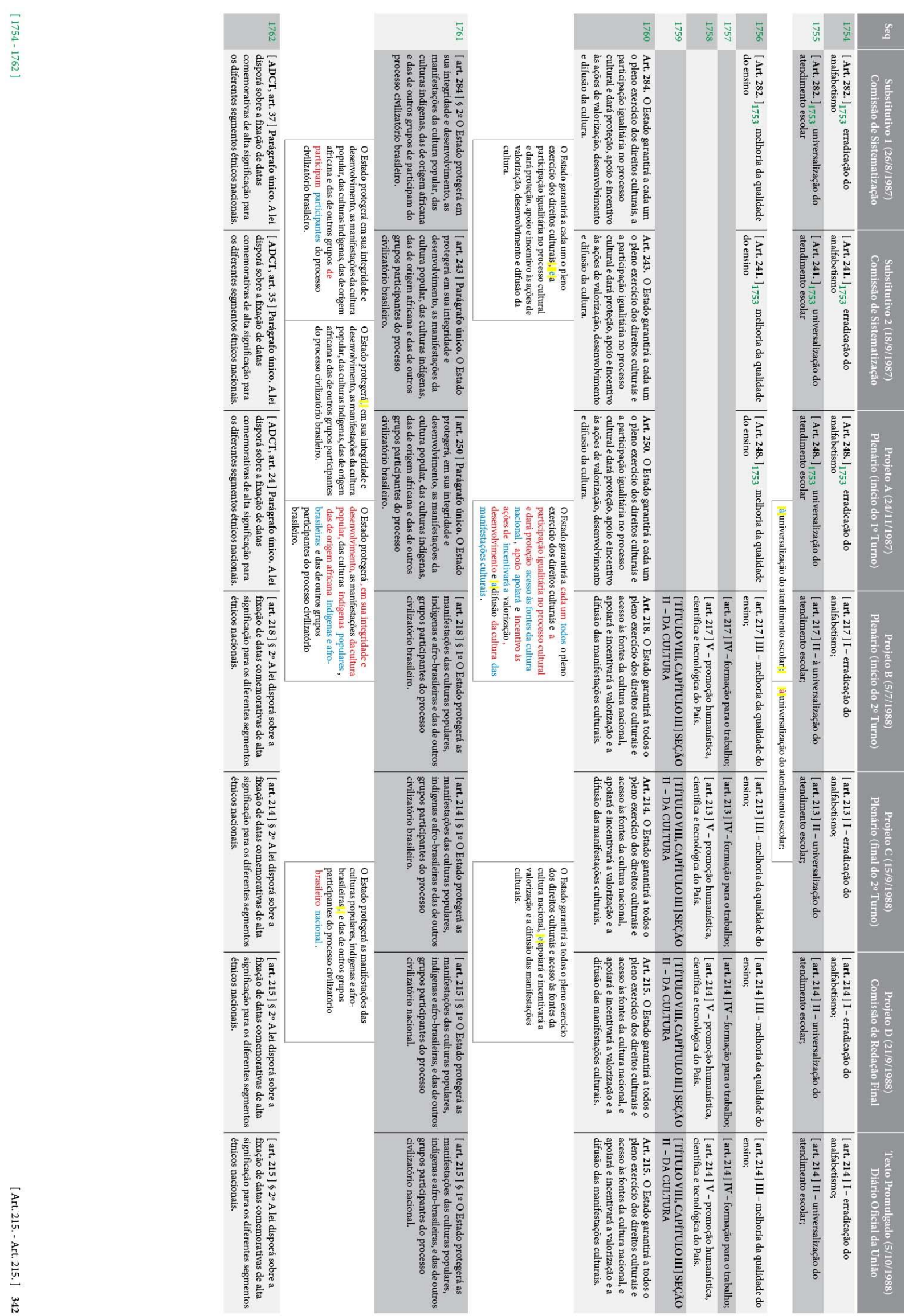




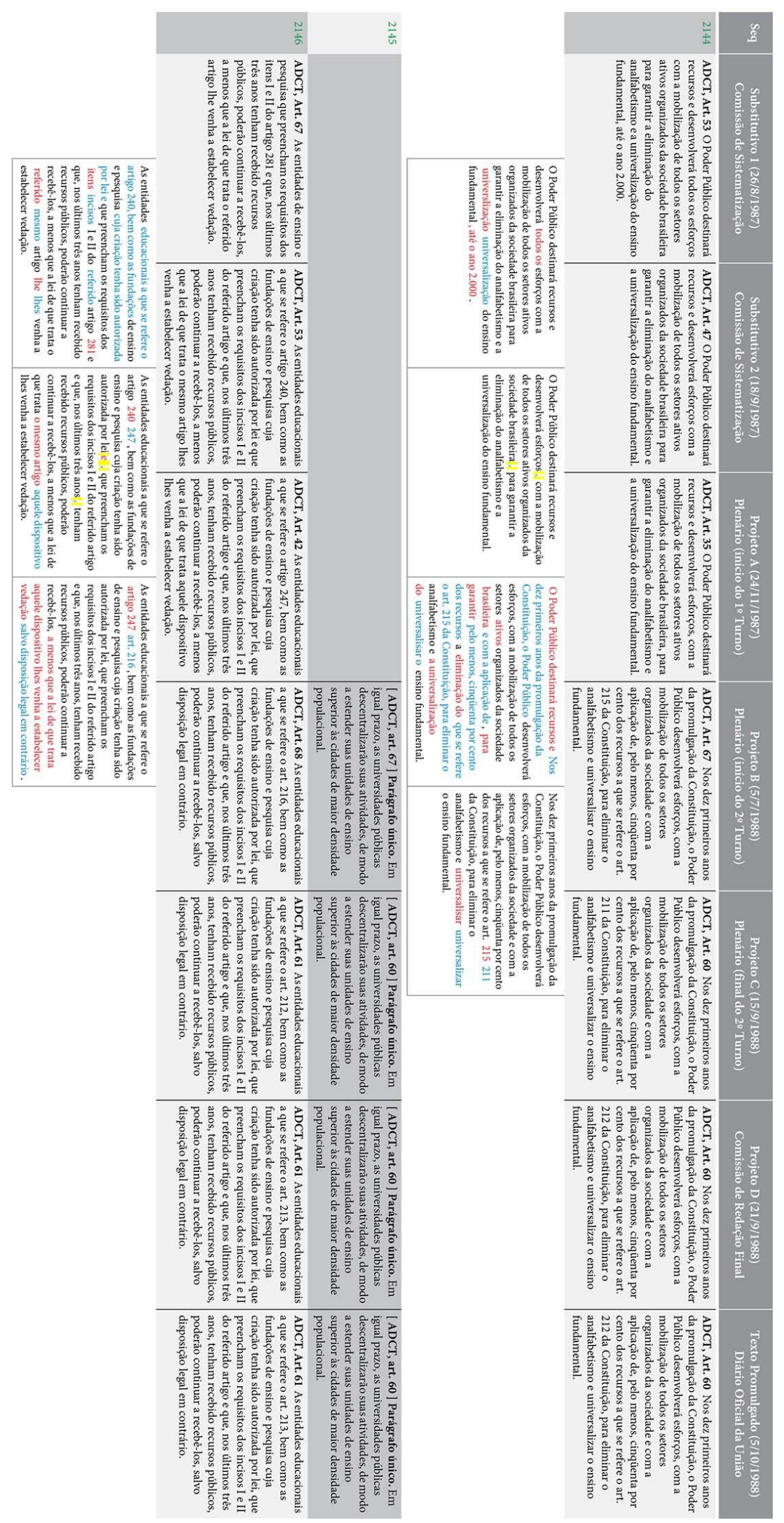

